\title{
Hydrogeological characterisation of karst aquifers in semi-arid environments at the catchment scale - Example of the Western Lower Jordan Valley
}

\author{
Dissertation \\ zur Erlangung des mathematisch-naturwissenschaftlichen Doktorgrades \\ "Doctor rerum naturalium" \\ der Georg-August-Universität Göttingen \\ im Promotionsprogramm Geowissenschaften \\ der Georg-August University School of Science (GAUSS)
}

vorgelegt von

Sebastian Schmidt

aus

Lichtenfels

Göttingen 2014 


\section{Betreuungsausschuss:}

Prof. Dr. Martin Sauter

Prof. Dr. Thomas Ptak

Prüfungskommission:

Referent: Prof. Dr. Martin Sauter

Korreferent: Prof. Dr. Heinz Hötzl

Weitere Mitglieder der Prüfungskommission:

Prof. Dr. Andrea Carminati

Dr. Tobias Geyer

Prof. Dr. Thomas Ptak

Prof. Dr. Hans Ruppert

Tag der mündlichen Prüfung
Abteilung Angewandte Geologie, Georg-August-Universität Göttingen

Abteilung Angewandte Geologie, Georg-August-Universität Göttingen

Abteilung Angewandte Geologie, Georg-August-Universität Göttingen

Institut für Angewandte Geowissenschaften, Karlsruher Institut für Technologie

Abteilung Bodenhydrologie, Georg-August-Universität Göttingen

Landesamt für Geologie, Rohstoffe und Bergbau im Regierungspräsidium Freiburg i. Br.

Abteilung Angewandte Geologie, Georg-August-Universität Göttingen

Abteilung Sedimentologie und Umweltgeologie, Georg-August-Universität Göttingen 


\section{Summary}

The main objective of the study is the characterisation of karstified carbonate aquifers in the semiarid climate zone, where groundwater resources are frequently threatened by overexploitation and pollution. Despite often limited system knowledge, quantitative and qualitative factors such as groundwater recharge rate, aquifer parameters, flow- and transport dynamics, anthropogenic impacts, and groundwater vulnerability need to be assessed. Apart from the challenges, semiarid environments provide advantages regarding karst system characterisation due to sharp and intensive recharge input signals alternating with undisturbed recession periods. This is the case for the study region located in the Eastern Mediterranean. Hydrologic system variability was assessed by an extensive high-resolution hydrometric and hydrochemical monitoring network, especially focussing on the karst springs. Additionally, long-term low-frequency data were assembled and analysed. It was aimed at the development and application of sophisticated methods kept as simple as possible in order to facilitate transferability.

For 33 springs in the study area, the natural background concentration of chloride in spring water was assessed by an analysis of long-term chloride and nitrate data. Together with chloride concentration data for local precipitation, the long-term mean natural groundwater recharge fraction of precipitation was calculated with the chloride mass balance method. Recharge ranged between $25 \%$ and $50 \%$ of the precipitation. The proportion of wastewater-borne spring flow was quantified by a chloride end-member mixing model. The larger springs in the area exhibited a wastewater-borne flow fraction between $0 \%$ and $20 \%$ calculated from recent samples.

To quantitatively assess spring aquifer hydraulic/geometric parameters at the catchment scale and groundwater recharge at a high time resolution, a minimally parameterised reservoir model was developed for the Auja spring, the largest freshwater spring in the Lower Jordan Valley. The Auja spring, as well as a number of other springs in the study area, display a discharge maximum, attributed to reaching the finite discharge capacity of the conduit system (flow threshold). Due to system complexity and non-linearity, features such as the flow threshold and a considerable conduit-matrix exchange needed to be incorporated into the model. Nevertheless, it is regarded as relatively simplistic and performs well for the highly variable flow conditions observed. As a number of parameters were calculated by a spring hydrograph recession and event analysis, it requires only six calibration parameters. The effective porosity of the spring aquifer system was estimated via model calibration at ca. $2.4 \%$. During the 45 -year simulation period, only five high precipitation years accounted for $33 \%$ of the total cumulative recharge.

Rapid recharge processes as well as the vulnerability of the groundwater sources (springs) were evaluated by assessing the hydraulic and transport signal time lags due to precipitation events, the duration of the event breakthrough, and the relative fraction of the fast flow discharge component. Focussing of infiltrated precipitation water in the epikarst zone and a subsequent rapid percolation along preferential pathways to the phreatic zone are regarded as important recharge processes in the study area. The transport data enable an evaluation of spring source vulnerability and provide valuable information for water resources management. Furthermore, the coherence of the two artesian Jericho springs Sultan and Duyuk, located $3500 \mathrm{~m}$ apart, to a common conduit and hence karst system could be established. 


\section{Zusammenfassung}

Ziel der Dissertation ist die hydrogeologische Charakterisierung von Karstgrundwasserleitern in der semi-ariden Klimazone, welche oftmals durch Übernutzung und anthropogene Verschmutzung bedroht sind. Trotz oft eingeschränkter Datenlage und einem unzureichenden Systemverständnis müssen quantitative und qualitative Faktoren, wie z.B. Grundwasserneubildungsrate, Aquiferparameter, Strömungs- und Stofftransportdynamik, Verschmutzungsempfindlichkeit und anthropogene Einflüsse quantifiziert werden. Jedoch können diese Gebiete auch günstige Eigenschaften für eine Charakterisierung, wie eine zeitlich eng begrenzte Impulsfunktion der Grundwasserneubildung durch intensive, kurze Niederschlagsereignisse sowie lange ungestörte Rezessionsperioden, aufweisen. Dies gilt für das in der Levante gelegene Untersuchungsgebiet. Die zeitliche und räumliche hydrologische Variabilität wurde durch ein ausgedehntes Messnetz hochaufgelöst erfasst. Zur Auswertung dieser Daten wurden konzeptionell korrekte, jedoch möglichst einfach anwendbare quantitative Verfahren und Modelle entwickelt und angewandt, was die Übertragbarkeit der Methoden auf weitere Trockengebiete ermöglicht.

Durch eine Zusammenstellung und Auswertung hydrochemischer Langzeitdaten konnte die natürliche Hintergrundkonzentration von Chlorid im Grundwasser für 33 Quelleinzugsgebiete ermittelt werden. Darauf aufbauend war es möglich, durch eine Chloridmassenbilanz sowohl den langjährige mittlere Anteil der Grundwasserneubildung am Niederschlag (25-50\%) zu bestimmen, als auch den Abwasseranteil im Quellwasser anhand rezenter Proben zu quantifizieren (0-20\%).

Anhand eines Speicher-Durchflussmodelles konnten sowohl Aquiferparameter im Einzugsgebietsmaßstab als auch eine Tageszeitreihe der Grundwasserneubildung exemplarisch für die Auja-Quelle, die größte Süßwasserquelle im Unteren Jordantal, erfasst werden. Diese sowie weitere Quellen der Region sind durch ein „röhrengedrosseltes“ Abflussverhalten, d.h. eine Begrenzung der Quellschüttung, gekennzeichnet. Der hydrogeologisch komplexe Aquifer und das nichtlineare Systemverhalten bei Erreichen der maximalen Schüttung erfordern ein besonders angepasstes Modell, welches auch einen ausgeprägten hydraulischen Austausch zwischen den Karströhren und der geklüfteten Gesteinsmatrix berücksichtigen muss. Eine Reihe von Parametern konnte aus einer Rezessions- und Ereignis-Analyse der Abflussganglinie ermittelt werden. Das Speicher-Durchflussmodell benötigt lediglich sechs Kalibrierparameter und erlaubt eine sehr gute Simulation der Abflussganglinie. Die effektive Aquifer-Porosität wurde durch Kalibration ermittelt (ca. 2.4\%). Über den simulierten 45-Jahres-Zeitraum führten die fünf niederschlagsreichsten Jahre zu einem Drittel der gesamten Grundwasserneubildung.

Die zeitlich hoch aufgelösten Quellmessungen ermöglichten eine Quantifizierung der hydraulischen Reaktionszeiten sowie der mittleren Verweilzeiten, der Durchbruchsdauer und der relativen Anteile der schnellen Fließkomponente nach Niederschlagsereignissen. Diese Daten dienen sowohl einer Abschätzung der schnellen Neubildungsprozesse (vor allem Fokussierung im Epikarst und schnelles präferentielles Fließen durch die Vadose Zone) als auch einer Beurteilung der Verschmutzungsempfindlichkeit der Karstquellen. Weiterhin konnte eine Zugehörigkeit der beiden, $3500 \mathrm{~m}$ voneinander entfernten, artesischen Jericho-Quellen Sultan und Duyuk zu einem gemeinsamen Röhren- und damit Karstsystem nachgewiesen werden. 


\section{Acknowledgements}

First and foremost my sincere thanks to Martin Sauter for the interesting research opportunity, the freedom to develop scientific ideas, and his support in multiple ways. With him and Tobias Geyer two experienced karst hydrogeologists were always (!) willing to discuss and to supportan ideal situation! Likewise many thanks to the further members of the committee: Andrea Carminati, Heinz Hötzl (also for acting as the second reviewer), Thomas Ptak, and Hans Ruppert.

The substantial amount of fieldwork in an interesting karst region of the world was much facilitated and turned into an unique experience by: Abdelrahman Tamimi, Abu Ashraf, Abu Shadi, Akiva Flexer, Amer Marei, Amer, Anat Yellin-Dror, Andrea Hanf, Anwar Zuhluf, Ata Ishtewe, Asaf Gotfeld, Ayman Jarrar, Ayman Shawana, Basir Hanna, Bassam Sawalhi, Clemens Messerschmid, David, Deeb Abdelghafour, Eli, Elisha, Fadi, Ghazi Al-Naji, Hamdan, Hazem Jumaa, Jalal Bsharrat, Klaus Haaken, Marwan Ghanem, Menachem Weiss, Mody, Mohammed Khalaf, Mohammed Najmi, Mustafa Nuseibeh, Nael, Nimrod Inbar, Omar Zayed, Shadha Musallam, Subhi Samhan, Yossi Guttman, Youval Arbel, Zoher, and anyone who's name I have forgotten, much to my regret, but who's help and discussion is equally appreciated.

Three people which might have missed their names in the above list are exemplary introduced: Steffen Fischer without his continuous support the results of the study would be less profound and likely some frustrating situation would have brought me very close to surrender but was turned into a funny episode instead, Fabian Ries who relieved me from a lot of field and organisational obligations during the second project phase and who i.a. gathered excellent data on surface runoff amounts, and Mathias Toll without his preparations and profound knowledge of the region the start of the endeavour would have been two orders of magnitude more difficult,

All colleagues in the geoscience centre, especially Anke von Gaza, Beka Peters-Kewitz, Bianca Wagner, Mechthild Rittmeier, Hartmut Düker, Joe Nadolski, Till Heinrichs, Tobias Licha, and Torsten Lange for various kinds of support,

All previous investigators from whose data I highly benefited, especially Mustafa Nuseibeh and his co-workers for their tremendous and superb monitoring over more than three decades,

The German taxpayers and the German Federal Ministry of Education and Research for funding the multi-lateral research project "SMART - Sustainable Management of Available Water Resources with Innovative Technologies". All SMART colleagues for discussion and some very nice experiences,

Office mates and fellow karst researchers Joanna Doummar, Jukey Jin, William Alkhoury, Jannes Kordilla, and Markus Giese for great experiences within and especially outside the scientific framework,

My family and friends for their continuous support and understanding, especially apologies to our late mother for the many hours of concern while conducting fieldwork in remote desert areas of the world commonly (but wrongfully) regarded as less convenient to travel to:

Shukran! Toda! Danke! 


\section{Table of Contents}

$\begin{array}{lr}\text { Introduction } & 1\end{array}$

$\begin{array}{ll}1.1 \text { Motivation } & 1\end{array}$

1.2 Challenges in karst system investigations 3

1.2.1 Hydrogeological characterisation and modelling challenges 3

1.2.2 Karst aquifer recharge estimation in semi-arid regions 5

$\begin{array}{lll}\text { 1.2.3 Karst aquifer vulnerability and natural (background) groundwater quality } & 7\end{array}$

$\begin{array}{ll}1.3 \text { Methodological background and approaches } & 8\end{array}$

1.3.1 Hydrometric and hydrochemical monitoring of karst aquifer systems - parameters 8

1.3.2 Determination of natural (background) groundwater quality 10

$\begin{array}{lll}\text { 1.3.3 Study site selection and description } & 11\end{array}$

$\begin{array}{lll}1.4 & \text { Research approach and outline of the thesis } & 13\end{array}$

2 Design and setup of a high resolution hydrometric monitoring network in a semi-arid karst environment - West Bank

2.1 Introduction $\quad 22$

$\begin{array}{ll}2.2 & \text { Study area and hydrogeologic challenges } \\ 2.32\end{array}$

$\begin{array}{lll}2.3 & \text { Setup of the monitoring network } & 23\end{array}$

2.3.1 Spring gauging stations and monitoring of spring physicochemical parameters $\quad 24$

$\begin{array}{ll}\text { 2.3.2 } & \text { Monitoring stations for groundwater level }\end{array}$

2.3.3 Meteorological stations, rain gauges and precipitation sampling 24

$\begin{array}{lll}\text { 2.3.4 Monitoring stations for flood runoff } & 25\end{array}$

2.3.5 Monitoring stations for soil moisture profiles $\quad 25$

$\begin{array}{llr}2.4 & \text { Selected results } & 25\end{array}$

3 Quantification of long-term wastewater impacts on karst groundwater resources in a semi-arid environment by chloride mass balance methods

3.1 Introduction 28

$\begin{array}{llr}3.2 & \text { Study area } & 30\end{array}$

3.2.1 Geography, climate, and surface hydrology 30

$\begin{array}{lll}\text { 3.2.2 Geology and hydrogeology } & 30\end{array}$

3.2.3 Land use, water supply and wastewater disposal 33

$\begin{array}{lll}3.3 & \text { Methods } & 33\end{array}$

3.3.1 Collection of the database 33

3.3.2 Identification of anthropogenically influenced springs 35

3.3.3 Assessing the natural background concentration of chloride in groundwater 36

3.3.4 Estimating long-term mean groundwater recharge 36

3.3.5 Discrimination of anthropogenic and geogenic sources of chloride in groundwater 37 by their $\mathrm{Cl}-/ \mathrm{Br}-$ and $\mathrm{Cl}-/ \mathrm{I}-$ ratios

3.3.6 Mixing model for the quantification of anthropogenic and geogenic chloride sources 38

$\begin{array}{lll}3.4 & \text { Results and discussion } & 38\end{array}$

3.4.1 Identification of anthropogenic influenced class 1 springs 38

3.4.2 Potential geogenic and anthropogenic chloride sources for class 2 springs 38

3.4.3 Additional wastewater indicators for the class 2 springs $\quad 42$

3.4.4 Hydrogeological implications of the chloride concentration trends 42

3.4.5 Estimation of natural background chloride concentration 43

3.4.6 Estimation of recharge by the chloride mass balance 44

3.4.7 Estimation of the wastewater-borne fraction of discharge for the class 2 springs $\quad 45$

3.4.8 Quantitative effects on spring discharge? 47

$\begin{array}{llr}3.5 & \text { Conclusions } & 47\end{array}$ 
$\begin{array}{llr}4.1 & \text { Introduction } & 58\end{array}$

$\begin{array}{llr}4.2 & \text { Case study area } & 61\end{array}$

4.2.1 General hydrogeologic setting $\quad 61$

4.2.2 Characteristics of Auja spring 61

4.2.3 Karst aquifer development and paleo-base levels in the Lower Jordan Valley region 63

4.3 Data collection and analysis $\quad 63$

4.3.1 Spring discharge $\quad 63$

4.3.2 Recession and event analysis of the Auja spring hydrograph 64

$\begin{array}{lll}\text { 4.3.3 Flow and recharge dynamics of the Auja spring system } & 67\end{array}$

4.3.4 Meteorological data and calculation of potential evapotranspiration $\quad 68$

$\begin{array}{llr}4.4 & \text { Reservoir model } & 68\end{array}$

$\begin{array}{lll}\text { 4.4.1 Soil/Epikarst Module (SEM) } & 69\end{array}$

$\begin{array}{lll}\text { 4.4.2 } & \text { Aquifer Module (AM) } & 70\end{array}$

$\begin{array}{lll}\text { 4.4.3 Parameter estimation } & 72\end{array}$

$\begin{array}{lll}\text { 4.4.4 Model calibration and input data provision } & 74\end{array}$

$\begin{array}{lll}\text { 4.4.5 } & \text { Modelling results } & 74\end{array}$

$\begin{array}{lll}\text { 4.4.6 Sensitivity analysis } & 76\end{array}$

$\begin{array}{lll}4.5 & \text { Discussion } & 76\end{array}$

$\begin{array}{lll}\text { 4.5.1 Hydrograph and recession analysis } & 76\end{array}$

$\begin{array}{lll}\text { 4.5.2 } & \text { Reservoir model and water balance } & 77\end{array}$

4.5.3 Implications for conduit restricted flow in the Jordan Valley region 79

$\begin{array}{llr}4.6 & \text { Conclusions } & 80\end{array}$

5 Evaluation of rapid recharge processes and spring source vulnerability of karst aquifers in semiarid environments based on high-resolution monitoring

$\begin{array}{llr}5.1 & \text { Introduction } & 88\end{array}$

$\begin{array}{llr}5.2 & \text { Study area } & 89\end{array}$

$\begin{array}{ll}5.3 \text { Methods } & 91\end{array}$

5.3.1 Monitoring of spring discharge and physicochemical parameters $\quad 91$

5.3.2 Monitoring of chloride concentration in precipitation and spring water 92

5.3.3 Estimation of the conduit volume of karst spring flow systems 92

5.3.4 Mixing model for hydrograph separation and anthropogenic impact quantification 93

5.3.5 Estimation of the mean residence time and discharge fraction of the fast flow 94 component

$\begin{array}{llr}5.4 & \text { Results and discussion } & 94\end{array}$

5.4.1 General flow system properties deduced from the high-resolution monitoring 94

5.4.2 Correlation between specific electrical conductivity and chloride concentration 96

5.4.3 Estimation of the variable fraction of the wastewater-borne discharge component 97

5.4.4 Implications of the precipitation input signal measurements 99

5.4.5 Estimated volumes of the conduit systems 99

5.4.6 Source vulnerability evaluation for the investigated springs 100

$\begin{array}{lll}\text { 5.4.7 } & \text { Determination of the groundwater recharge processes } & 103\end{array}$

$\begin{array}{llr}5.5 & \text { Conclusions and outlook } & 105\end{array}$

6 Conclusions

$\begin{array}{lll}6.1 & \text { Integration and evaluation of characterisation methods and results } & 111\end{array}$

6.2 Monitoring and characterisation strategy for karst aquifers in semi-arid environments 113

$\begin{array}{ll}6.3 & \text { Perspectives } \\ & 115\end{array}$ 


\section{List of Figures}

Figure 1.1 Humidity-index map of the world with outcrop areas of carbonate rocks 1

Figure 1.2 Conceptual block diagram of a karstified carbonate aquifer in a semi-arid environment 3

Figure 1.3 Key hydrometric and hydrochemical monitoring parameters for karst systems 8

Figure 1.4 Timescales of hydrological monitoring 9

Figure 1.5 Detail of an aerial photograph of Jericho from May $1918 \quad 11$

Figure 1.6 60-year annual precipitation time series measured at Jerusalem meteorological station 13

Figure 2.1 Schematic hydrogeologic cross section through the study area 22

Figure 2.2 Map of the study area with the main components of the monitoring network 23

$\begin{array}{lll}\text { Figure } 2.3 \quad \text { Examples of installations } & 24\end{array}$

Figure 3.1 Map of the study area $\quad 31$

Figure 3.2 Schematic cross-section through the study area 31

Figure 3.3 Stratigraphic table of the Cretaceous formations in the study area 32

Figure 3.4 Chloride concentration time series of the eight class 2 springs 39

$\begin{array}{lll}\text { Figure 3.5 Nitrate concentration time series of the class } 2 \text { springs } & 40\end{array}$

Figure 3.6 Annual precipitation depths for Jerusalem for 100 hydrological years 40

Figure 3.7 Chloride vs. $\mathrm{Cl}^{-} / \mathrm{Br}^{-}$mass ratio plot of spring water and potential end members 41

$\begin{array}{lll}\text { Figure } 3.8 \quad \text { Recharge fractions estimated for the springs of class } 1 \text { and } 2 & 45\end{array}$

Figure 4.1 Examples of conceptual models with convex discharge recession behaviour 60

Figure 4.2 Map of the study area displaying the outcrop areas of the geological strata 62

Figure 4.3 Auja spring in March $2009 \quad 62$

Figure 4.4 High resolution hydrograph of Auja spring during 2009-2012 64

Figure 4.5 Schematics of the complex recession behaviour of the Auja spring flow system 65

Figure 4.6 Relationship between recession coefficient $\alpha$ and the amount of water discharged 66

Figure 4.7 Hydrographs of Auja spring discharge and water level in a monitoring well 67

$\begin{array}{lll}\text { Figure } 4.8 \quad \text { Schematic representation of the reservoir model } & 69\end{array}$

$\begin{array}{lll}\text { Figure 4.9 Comparison of measured and modelled spring discharge } & 75\end{array}$

Figure 4.10 Annual calculated groundwater recharge for 45 individual hydrological years $\quad 75$

$\begin{array}{lll}\text { Figure } 4.11 \quad \text { Sensitivity of selected model parameters } & 76\end{array}$

$\begin{array}{lll}\text { Figure 5.1 Overview map of the study area } & 90\end{array}$

Figure 5.2 Characteristic times of precipitation events and spring responses 93

Figure 5.3 Time series monitored during the hydrological years of 2011 and 201295

Figure 5.4 Close-up of the high-resolution time series for the winter season 2011/2012 96

Figure 5.5 Correlation between electrical conductivity and chloride concentration in spring water 96

Figure 5.6 Sultan spring discharge and chloride concentration during 1938-1940 97

$\begin{array}{lll}\text { Figure } 5.7 \quad \text { Calculated wastewater-borne flow fraction at the Sultan spring } & 98\end{array}$

$\begin{array}{lll}\text { Figure 5.8 Comparison of the event water fractions observed at the springs } & 100\end{array}$

$\begin{array}{lll}\text { Figure 5.9 Recharge event 2012-2 monitored at Samia spring } & 104\end{array}$

Figure 6.1 Empirical polynomial equation for groundwater recharge estimation $\quad 112$ 


\section{List of Tables}

Table 1.1 Methods for the determination of the natural background concentration

Table $3.1 \quad$ Classification scheme for the springs in the study area

Table $3.2 \quad$ Mean precipitation chloride concentration of the Jerusalem region 34

Table 3.3 Overview of the different spring water hydrochemistry monitoring periods 34

Table 3.4 Mean chloride concentration of wastewater treatment plant effluents 35

Table $3.5 \quad$ Calculated background chloride concentration and mean groundwater recharge fraction 44

Table 3.6 Sampling results for the class 2 springs 46

Appendix A Compiled data and calculations for the analysed springs 49

Table 4.1 Characteristic recession coefficients derived from the analysis of the long-term data $\quad 64$

Table 4.2 Recharge event and recession analysis of the high resolution monitoring data 2009-2012 66

Table 4.3 Parameters used for the setup and calibration of the reservoir model

Table 5.1 Summary of the long-term discharge data (hydrological years 1968-2000) 90

Table 5.2 Automatically monitored spring parameters and temporal resolution 91

$\begin{array}{lll}\text { Table } 5.3 & \text { Compilation and comparison of the large precipitation event signals } & 101\end{array}$

Table 5.4 Summary of the spring characteristics based on Table 5.3 $\quad$ Su2

Table 6.1 Ratio of maximum observed to mean spring discharge for the monitored springs 


\section{Chapter I}

\section{Introduction}

\section{I.I Motivation}

In dry climates often the bulk amount of potable water used for domestic and agricultural purposes is abstracted from aquifers, some of which are intensively developed (AeschbachHertig and Gleeson, 2012). Since recharge rates to those aquifers are usually low (Scanlon et al., 2006), groundwater resources are frequently threatened by overexploitation (Custodio, 2002). Furthermore, groundwater is vulnerable with respect to various pollution sources and abstraction-induced processes like salinsation (Foster and Chilton, 2003). For the development and management of groundwater resources and to prevent overexploitation and pollution, a thorough hydrogeological characterisation of the aquifer system and a dependable estimate of recharge rates based on reliable monitoring data are prerequisites. However, especially in arid and semi-arid regions, hydrological data are often scarce (Simmers, 1990).

Karst aquifers exhibit distinct hydrogeological properties compared to unconsolidated granular aquifers and their characterisation is complex (Bakalowicz, 2005). They evolve in relatively soluble rocks such as carbonates and evaporites by dissolution (White, 1988). In this thesis only aquifers in carbonate rocks are considered (Fig. 1.1). It is estimated that carbonate karst occurs over $10-15 \%$ of the world's continent surface (Ford and Williams, 2007).

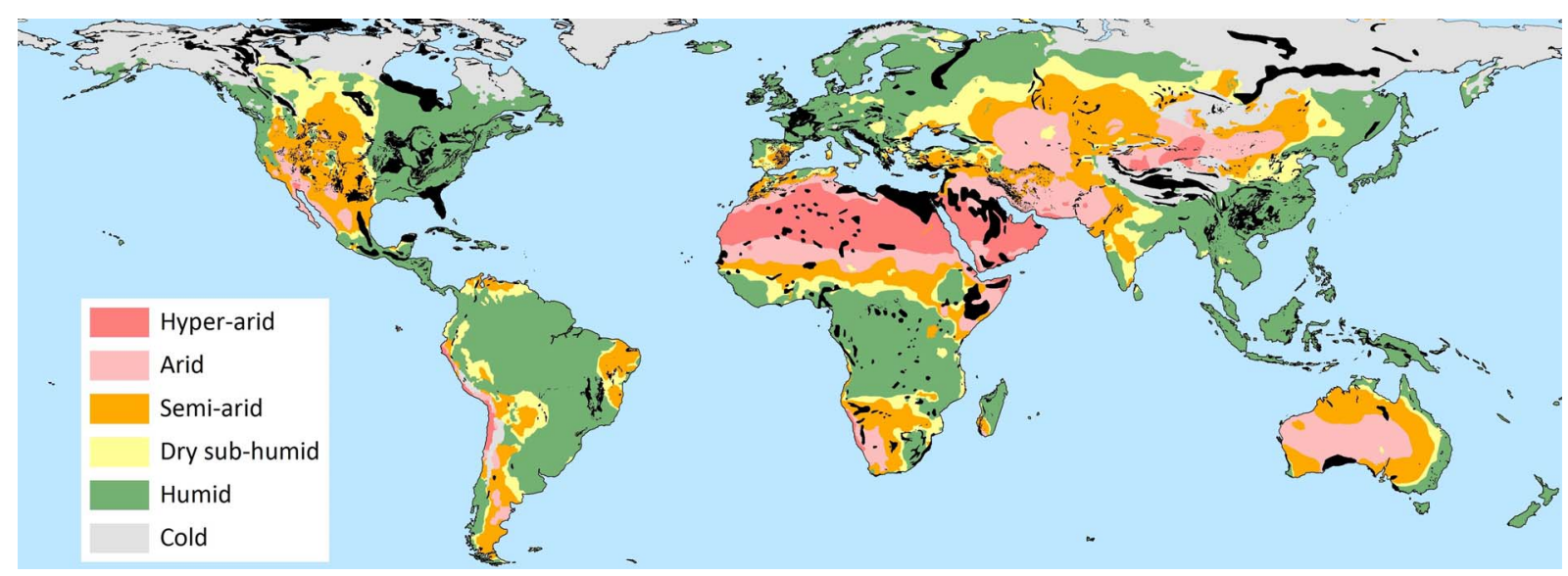

Fig. 1.1: Humidity-index map of the world with outcrop areas of carbonate rocks (outcrop areas in black, from the University of Auckland, New Zealand: web.env.auckland.ac.nz/our_research/karst/, with friendly permission from Paul Williams; humidity data from UNEP, 2013). 


\section{Introduction}

Climate is often classified according to meteorological parameters, e.g. precipitation and air temperature, as applied in the frequently used Köppen-Geiger classification (e.g. Kottek et al., 2006; Peel et al., 2007). UNESCO (1979) provides a relatively simplistic classification scheme according to the ratio of mean precipitation to mean potential evapotranspiration: humid $(>0.65)$, dry sub-humid (0.50-0.65), semi-arid (0.20-0.50), arid (0.03-0.20), and hyper-arid $(<0.03)$, which is adopted in this study. A considerable percentage of the worlds carbonate outcrop area is located in the semi-arid climatic zone (Fig. 1.1), especially around the Mediterranean Sea (e.g. Spain, Maghreb countries, Turkey, Levant countries), in North America, Africa, Asia, and Australia.

The geomorphological and hydrogeological characteristics of karst environments are a function of factors such as the carbonate rock lithology (e.g. purity of the carbonate rock), carbonate rock thickness, geological structure, relief, stability of the hydrological base-level, precipitation depth, air temperature, $\mathrm{CO}_{2}$ production in the soil, and time (e.g. White, 1988). The relative effect of climate on karst geomorphology and hydrology is a matter of debate (see discussions in Sweeting, 1972; Jennings 1985; Ford and Williams, 2007). Due to its influence on important factors such as precipitation depth and availability of $\mathrm{CO}_{2}$, it is certainly of major importance (e.g. White, 1988). However, particularly karst geomorphology in (semi-)arid climates is not well investigated (Ford and Williams, 2007). Due to the high intensity and short duration of precipitation events and the usually thin and discontinuous soils, karst features are not very well developed in semiarid regions (Ford and Williams, 2007). Dolines, typical karst features in temperate humid environments, are scarce or completely absent and the surface morphology is fluvial (dry valleys with very episodic surface flow) in many cases (Sweeting, 1972; Ford and Williams, 2007): "There are regular Hortonian patterns of dry valleys with rounded interfluves in gentle uplands, or of steeperwalled canyons or reculées dissecting massifs and plateaus. Both types lose most storm runoff into small solutional shafts (ponors) along the thalwegs. This is true of the Judean Hills around Jerusalem, the Edwards Plateau of Texas and, more spectacular, the reefal Guadalupe Mountains (New Mexico-Texas) ... These three limestone examples all extend across the semi-arid to arid climatic transitions in their respective regions. ... Nevertheless, they supply regionally important aquifers that usually discharge at just one or a few large springs at the junction between limestone uplands and desert detrital plains." (Ford and Williams, 2007, p. 402).

Despite their importance, the hydrogeology of (semi-)arid karst aquifers was investigated to a often lesser degree: "Much of the arid zone is underlain by karstic or fractured carbonate or silicate aquifers where very little research has been carried out compared with porous media. The main reason that they have been avoided is because research in these areas is very complex, and observational data can confound conventional interpretation approaches." (Herczeg and Leaney, 2011, p. 27).

For the characterisation and modelling of karst aquifers in semi-arid environments, a core requirement is a substantial hydrological database. Data collection often requires a monitoring scheme adapted to the specific dry-region conditions. The characterisation of the hydrogeological system requires an approach integrating various methods. A number of methods developed for temperate humid environments may be transferred to (semi-)arid regions, although this transfer may be questionable concerning the different natural conditions encountered (Van Lanen and Carrillo-Rivera, 1998). As indicated by Herczeg and Leaney (2011), it may be necessary to develop especially adapted methods in order to analyse and interpret the hydrogeological data obtained. 


\section{I.2 Challenges in karst system investigations}

\section{I.2.I Hydrogeological characterisation and modelling challenges}

The process of karstification leads to important heterogeneities and anisotropy regarding porosity and permeability (e.g. Király, 2002). Accordingly, the hydrogeological characterisation of karst aquifers is usually more complex compared to granular or fractured aquifers:

(1) Characterisation of the water storage in karst systems: White (1988) proposed a triple porosity conceptual model of primary-, fracture-, and conduit porosity. Many conceptual karst aquifer models combine primary and fracture porosity as fractured rock matrix, which is believed to constitute the bulk groundwater storage of the aquifer (e.g. Atkinson, 1977; Király, 2002; Fig. 1.2). In contrast, frequently a low proportion of the aquifer storage is attributed to the conduit system. For example, effective porosity values of about $0.03 \%$ were calculated by Atkinson (1977) and Sauter (1992) for the conduit system of mature karst aquifers. Alternative models of storage were proposed (see Bakalowicz, 2005): Mangin (1975) attributed storage to large karst voids connected to the conduit system (system annexes). Williams (1983) attributed a considerable storage to the epikarst zone of certain karst aquifers.

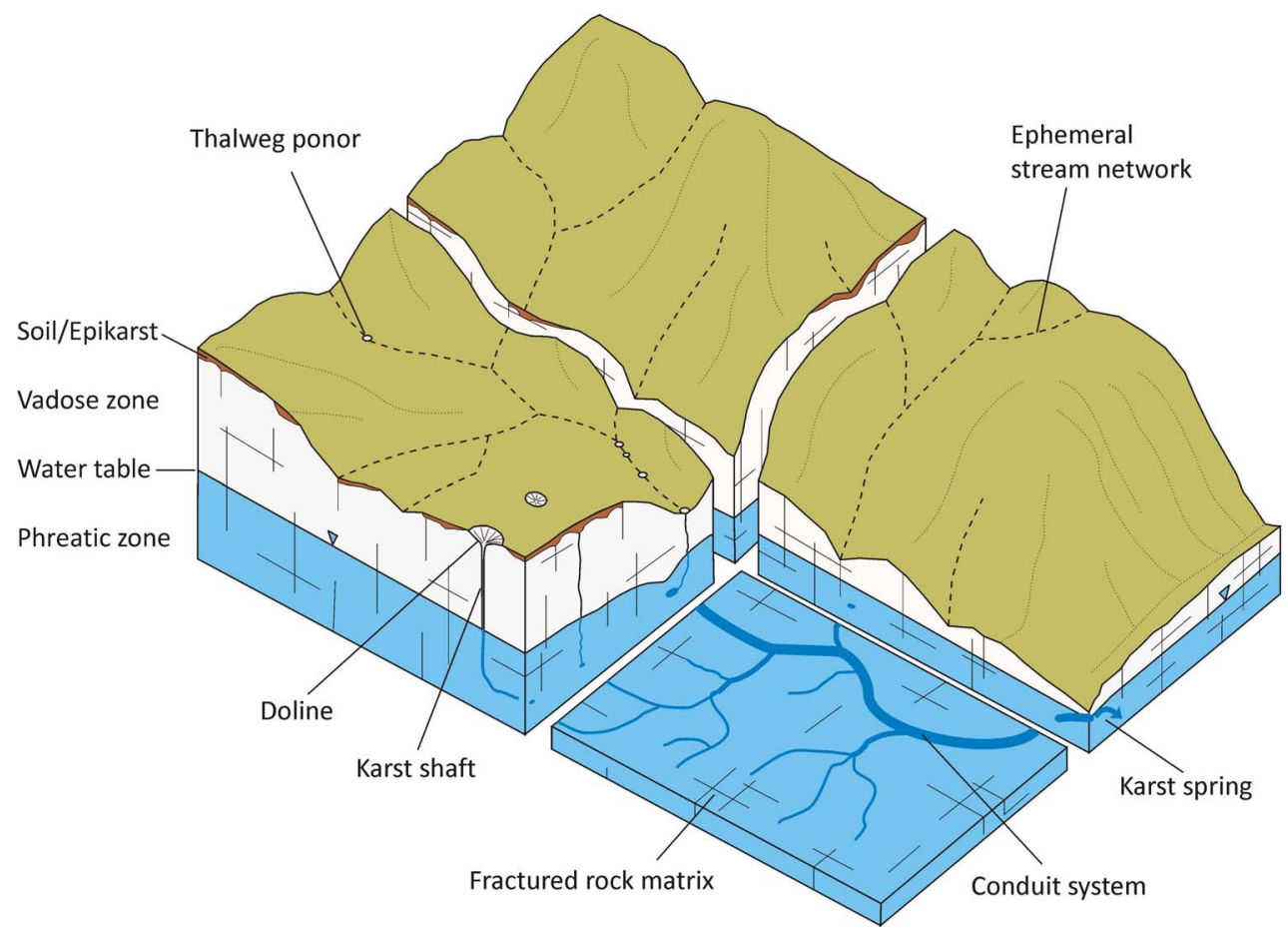

Fig. 1.2: Conceptual block diagram of a karstified carbonate aquifer in a semi-arid environment (Figure inspired by conceptual diagrams of Mangin, 1975 and Geyer, 2008).

(2) Large hydraulic conductivity contrasts: Within a karst aquifer, hydraulic conductivity can vary by around 10 orders of magnitude (Freeze and Cherry, 1979; White, 1988; Király, 2002), depending also on the scale of the investigation (Sauter, 1992; Király, 2002). This high contrast in hydraulic conductivity also leads to highly contrasting flow velocities and residence times in the 
different compartments of the aquifer, which complicates the assessment of solute and contaminant transport (Geyer, 2008; Kresic, 2013).

(3) Variable flow regimes: whereas within the small-scale primary pores and fractures, flow is considered to be laminar, in the conduits and in solutionally enlarged fractures, flow is expected to be turbulent (White, 1988). Furthermore, conduit flow can be differentiated into full pipe flow and open channel flow (e.g. White, 1988). To describe those different flow regimes adequately, different flow equations may be required for a given karst aquifer.

(4) Delineation of groundwater catchments: Due to the high hydraulic conductivity of the conduit system, the groundwater head gradients in mature karst aquifers are often comparatively low. In thick carbonate rock units this leads to the development of thick vadose zones, especially in mountainous terrain, where the unsaturated zone often displays a thickness of several hundred meters (e.g. White, 1988; Andreu et al., 2011). Because of the thick vadose zones the access to the water table, for example by monitoring wells, is usually very restricted. For this reason and due to the presence of preferential flow pathways, the delineation of groundwater catchments in karst aquifers is very difficult. Classical groundwater catchment delineation methods like potentiometric surface mapping are restricted to karst aquifers with a thin unsaturated zone and low conductivity contrasts, but nevertheless require a large number of monitoring wells (e.g. Quinlan, 1982). A method specifically used for groundwater catchment delineation in karst environments are artificial water tracing experiments, mostly employing fluorescent dyes as tracers (e.g. Worthington and Smart, 2013). However, this method requires suitable tracer input locations like ponors (swallow holes), karst shafts, and dolines (sinkholes). In semi-arid karst regions, the identification of suitable tracer input locations is difficult due to the paucity of permanent sinking streams and dolines. Thalweg ponors (George, 1989; Ford and Williams, 2007), if present, are likely obscured by alluvial sediments deposited in the ephemeral stream valleys. Furthermore, during flash floods, a site inspection in the ephemeral valleys for ponor zone identification is often not feasible.

Because of the complex hydraulic parameter field, flow- and transport modelling of karst aquifers is extremely challenging (e.g. Király, 2002). Models need to conceptually consider the hydraulically governing conduit network, which is often characterised by turbulent flow (Kresic, 2013). Depending on the conceptual model and the available data regarding aquifer geometry and hydraulic parameters, different mathematical modelling approaches can be employed (e.g. Kovács and Sauter, 2007). The type of model requiring the least knowledge about the system are black box models, for example analysing the transfer of precipitation to spring discharge by regression or correlation methods (e.g. Kresic, 2013). However, those models exhibit no predictive power regarding aquifer management considerations, e.g. evaluating abstraction scenarios (Kresic, 2013). Reservoir models treat the system as a linear reservoir or a series of reservoirs, depending on the complexity of the system. Often a series of two coupled groundwater reservoirs is applied, in order to represent the fast- (conduit) and slow- (fractured rock matrix) flow system (e.g. Fleury et al., 2007; Hartmann et al., 2012). Distributed physically based models are the most demanding with respect to input data and computational effort (Kovács and Sauter, 2007; Kresic, 2013). Hereby hybrid models couple a discrete pipe system with a continuous "matrix" by exchange terms depending on groundwater head in the respective compartments (e.g. Liedl et al., 2003). However, the location and hydraulic properties of the highly permeable structures are 
usually unknown, even in well investigated aquifers. Therefore, for distributed model setup, assumptions regarding the location and hydraulic conductivity of those structures need to be made (e.g. Weiss and Gvirtzman, 2007; Doummar et al., 2012). In sum, model selection is a critical step in karst aquifer simulation and prediction and needs to be specifically tailored to the hydrogeological problem.

\section{I.2.2 Karst aquifer recharge estimation in semi-arid regions}

From a groundwater management perspective, recharge is the most important component of the hydrological cycle to assess, especially in arid and semi-arid environments (Simmers, 1990). Because of groundwater abstraction exceeding the natural replenishment rate, a groundwater head decline is observed in many semi-arid karst aquifers, causing a drying-up of the springs (e.g. Custodio, 2002; Martínez-Santos and Andreu, 2010; Sheffer et al., 2010; Hartmann et al., 2012; Martos-Rosillo et al., 2013). However, in (semi-)arid environments, recharge is the water balance component regarded as most difficult to assess (Simmers, 1990; Hogan et al., 2004).

Groundwater recharge is considered as the vertical movement of water from the vadose zone to the phreatic zone across the water table (Freeze and Cherry, 1979). Subsurface inflow (e.g. leakage) from adjacent aquifers is not considered recharge in this definition. Regarding the different processes and mechanisms of recharge the terminology as proposed, for example, by Scanlon et al. (2002) and Healy (2010) is adopted: Diffuse recharge is considered as the area-wide occurrence of recharge following an excess of soil water deficits by precipitation (Simmers, 1997). Focussed recharge involves a concentration of flow at the surface or in the shallow subsurface. Examples are the infiltration of surface water into ponors (Figs. 1.2 and 1.3) or a flow concentration in the epikarst (Gunn, 1983; Williams, 1983). The movement of water through the unsaturated zone below the root zone is termed percolation. This quantity may be termed potential recharge and will become actual recharge upon reaching the water table (Scanlon et al., 2002). Nevertheless it may remain in storage in the unsaturated zone for a considerable period of time (Healy, 2010). In this context, rapid recharge implies that recharge adds to groundwater storage within a short time lag after the precipitation event (e.g. within a couple of days). Thereby the rapid transfer through thick unsaturated zones usually presupposes a focussing mechanism. The recharge originating from precipitation over the outcrop area of the carbonate aquifer rocks is termed autogenic recharge, the recharge originating from surface water inflow from non-karst rocks adjacent or overlying the carbonate aquifer is called allogenic recharge (Fig. 1.3) (Gunn, 1983).

Because recharge can only in specific instances be measured directly, it needs to be estimated. For this purpose a variety of methods may be applied (e.g. Lerner et al, 1990; Scanlon et al., 2002; Healy, 2010). The methods need to be selected depending on the recharge mechanism, the purpose of the recharge estimate (e.g. water resources assessment, contaminant transport assessment), and the availability of hydrological data (Healy, 2010). Simmers (1990) and Healy (2010) regard recharge estimation as an iterative process, where new measurements lead to more accurate estimates or sometimes even to the rejection of the hitherto applied conceptual model. The suite of applicable recharge estimation methods differs between humid and arid climates (Scanlon et al., 2002). In arid settings, often a thick vadose zone is present, separating the groundwater system from surface water bodies: "Recharge is generally considered to occur in 


\section{Introduction}

topographic highs and discharge in topographic lows in humid regions, whereas in arid alluvial-valley regions recharge is usually focused in topographic lows, such as channels of ephemeral streams."(Scanlon et al., 2002, p. 20). Opposing a strict humid-arid end-member scheme, one may argue that karst aquifers in humid climate regions are often characterised by the presence of thick vadose zones as well. Therefore, despite the expected higher importance of focussed recharge in the more arid settings, basic recharge processes may be relatively similar in the different climate zones.

Recharge estimation methodologies for all aquifer types in (semi-)arid environments, some with a regional focus, were reviewed and compiled for example by Gee and Hillel (1988), Lerner et al. (1990), Simmers (Ed.) (1997), Kinzelbach et al. (2002), Xu and Beekman (2003), Hogan et al. (2004), Scanlon et al. (2006), Stonestrom et al. (2007), and Healy (2010). However, in those reviews, karst aquifers are often underrepresented. In recent years, recharge studies specifically dedicated to karst aquifers in semi-arid environments were conducted, for example, in southern Spain (e.g. Martínez-Santos and Andreu, 2010; Alcalá et al., 2011; Andreu et al., 2011). These studies applied various recharge estimation methods to a number of different aquifers. A highly variable mean aquifer recharge fraction of precipitation, ranging between $4 \%$ and $47 \%$, was found (Andreu et al., 2011), however often in the order of $30 \%$. These are rather high values compared to recharge fractions of $0.1-5 \%$ generally evaluated for semi-arid and arid regions (Scanlon et al., 2006). Even higher recharge fractions may be observed in sub-humid "mountain inliers" in semi-arid regions. For example, for the mountainous (elevations up to $2500 \mathrm{~m}$ ) karst catchment of the Figeh spring in Syria, Al-Charideh (2012) calculated a mean recharge fraction of precipitation of $63 \%$.

The hydrogeological heterogeneity of karst aquifers prevents the application of many standard recharge estimation methods. For example, despite the usual presence of thick vadose zones, due to preferential flow pathways (Gee and Hillel, 1988), the variety of unsaturated zone methods usually cannot be applied. Therefore, groundwater based approaches are often preferred. For example, for a known catchment area, the long-term mean aquifer (spring) discharge $Q$ will equal mean catchment groundwater recharge $R$, provided that changes in groundwater storage $\Delta S$ are negligible (groundwater budget approach). Furthermore, the chloride mass balance method (Schoeller, 1960) based on groundwater chloride data is frequently applied to karst aquifers in semi-arid climate regions (e.g. Marei et al., 2010; Andreu et al., 2011; Al-Charideh, 2012). Those methods provide recharge rates averaged over long time periods and large spatial scales (Scanlon et al., 2002). Estimates of deep percolation $D P$ with a higher temporal resolution may be obtained by a soil-water balance model: $P=E T a+D P+S R+\Delta S$ s, with precipitation $P$, actual evapotranspiration $E T a$, surface runoff leaving the catchment $S R$, and changes in soil water storage $\Delta S$ s. However, due to diverse problems concerning spatial parameter measurement, the applicability of this method is questioned for (semi-)arid environments (e.g. Gee and Hillel, 1988). A groundwater based method providing higher resolution recharge estimates is the water table fluctuation method. Due to the large heterogeneities in karst systems, this method needs to be applied with caution, too (Healy and Cook, 2002). Yet, a rise in hydraulic head in response to a precipitation event is a confirmation for actual ground water recharge taking place (Kresic, 2013).

As every recharge estimation method exhibits specific weaknesses, it is often advocated to apply multiple methods to one study area (e.g. Simmers, 1990), ideally methods that complement each other (Scanlon et al., 2002). Simple methods-carefully applied-are preferred to complex methods which may be restricted to a specific site (Healy, 2010). 


\section{I.2.3 Karst aquifer vulnerability and natural (background) groundwater quality}

Due to often focussed and rapid recharge processes and high groundwater flow velocities in the conduit systems, karst groundwater resources are often particularly vulnerable to pollution (Daly et al., 2002). Water recharged in parts of the groundwater catchment connected to the conduit system (e.g. infiltration of surface streams into ponors) can display a very rapid transit to karst springs despite large distances (Foster et al., 2013). For example, Worthington and Smart (2013) obtained a geometric mean dominant conduit flow velocity of about $120 \mathrm{~m} \mathrm{~h}^{-1}$ from an analysis of 211 sink to spring tracer tests. In contrast, a lower vulnerability is attributed to the sections of the recharge area characterised by diffuse recharge (e.g. Quinlan et al., 1991). Therefore, groundwater protection measures, such as groundwater protection zoning are very complex in karst environments. For example, determination procedures for the so-called inner protection zone (zone to prevent all kinds of contamination, particularly microbiological), such as 50-day line of travel time determination applied to unconsolidated porous aquifers, are hardly feasible in karst aquifers (Goldscheider, 2010). In order to assess the relative vulnerability of groundwater in different parts of an aquifer recharge area, vulnerability mapping and index methods are widely applied (e.g. Daly et al., 2002; Zwahlen, 2004; Goldscheider, 2010). Those methods provide static values, which are adequate for groundwater resource protection (protection of the entire groundwater body; see further Hötzl, 1996; Goldscheider, 2002). For groundwater source protection (protection of groundwater quality at the abstraction point, i.e. spring or well), also the dynamic aspects of vulnerability, for example the state of the hydrologic system, have to be taken into account (Butscher and Huggenberger, 2008; Doummar, 2012).

The natural geochemistry of groundwater is a function of atmospheric input (wet and dry deposition), processes in the soil zone (e.g. evapotranspiration, biogeochemical processes), and processes in the unsaturated and saturated zones (e.g. mineral dissolution, redox processes, ion exchange) (Appelo and Postma, 2005; Edmunds and Shand, 2008). Therefore, the solute concentration in groundwater is influenced by factors such as climate, distance from the coast, soil biological activity, aquifer lithology, and water residence time in the aquifer. As carbonate rocks are often relatively pure, the largest part of the ionic composition of karst groundwater is usually derived from the dissolution of carbonate minerals and is constituted by the ions $\mathrm{Ca}^{2+}$, $\mathrm{Mg}^{2+}$ (depending on the presence of dolomite in the carbonate rock sequence), and $\mathrm{HCO}_{3}^{-}$(e.g. White, 1988; Appelo and Postma, 2005). Other major ions like e.g. $\mathrm{SO}_{4}{ }^{2-}, \mathrm{Cl}^{-}, \mathrm{Na}^{+}, \mathrm{K}^{+}$are largely derived from atmospheric precipitation and weathering of non-carbonate minerals.

Natural groundwater quality is increasingly influenced worldwide by anthropogenic activities (Foster and Chilton, 2003). Widespread contaminants are inorganic compounds such as nitrate (e.g. from fertilisers), organic compounds like aromatic and halogenated hydrocarbons, and microbial contaminants (pathogen bacteria and viruses) (e.g. Goldscheider, 2010; Kresic, 2013). Point source contamination (e.g. localised infiltration of treated or untreated wastewater) is distinguished from diffuse contamination (e.g. nitrate and pesticides from aerial agricultural practices). In order to identify and subsequently prevent the polluting activities and to set goals for a groundwater quality restoration, the size of the contamination needs to be determined. For contaminants naturally present in groundwater (e.g. $\mathrm{NO}_{3}{ }^{-}, \mathrm{SO}_{4}{ }^{2-}, \mathrm{Cl}^{-}$), this is not straightforward and requires the determination of the natural background concentration of solutes for the groundwater body. 


\section{I.3 Methodological background and approaches}

\section{I.3.I Hydrometric and hydrochemical monitoring of karst aquifer systems - parameters and resolution}

The characterisation, modelling, and management of karst aquifers (or any hydrological catchment in general) requires the monitoring of quantitative and qualitative system parameters. Quantitatively, the components of the soil/aquifer system water balance need to be assessed (i.e. precipitation $P$, actual evapotranspiration $E T a$, groundwater recharge $R$, changes in groundwater storage $\Delta S$, and groundwater discharge $Q ;$ Fig. 1.3). These components cannot be measured equally well and display a variable degree of heterogeneity in space and time. For example, spatially homogeneous precipitation over the catchment area may be conveniently assessed by a number of rain gauges. In contrast, due to the heterogeneity of soil and land use characteristics (e.g. geologic parent material, soil thickness, soil hydraulic properties, vegetation, etc.), parameters like actual evapotranspiration and percolation from the soil/epikarst zone are much more difficult to be measured directly. Direct measurement of groundwater recharge is often impossible, especially on large spatial scales.

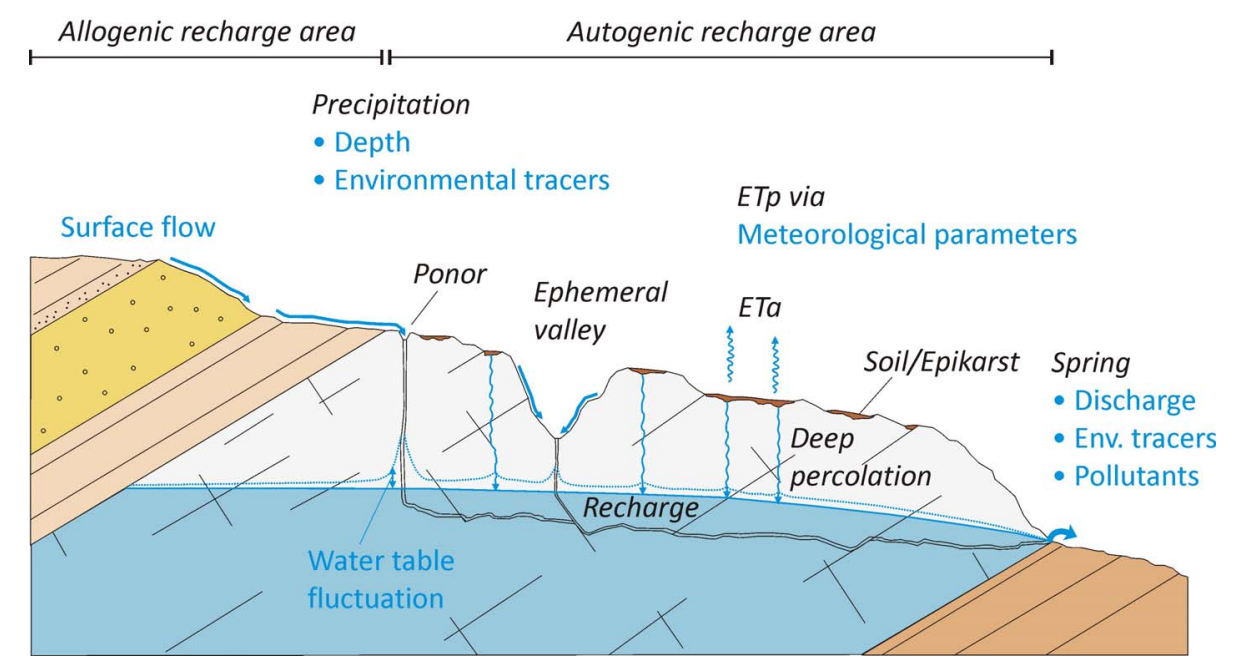

Fig. 1.3: Key hydrometric and hydrochemical monitoring parameters for karst systems (blue typeface).

Groundwater discharge of karst aquifers may occur at springs or as rather diffuse discharge to a river. If discharge occurs via a single or a limited number of springs, this component of the hydrological cycle can be assessed on a catchment scale (White, 2002; Bakalowicz, 2005). Because of this balancing possibility, the spring catchment scale is considered the most appropriate one for system characterisation and modelling. The size of spring groundwater catchments may range from a fraction of a square kilometre for a spring draining a small perched aquifer (e.g. Fuente Alta, Alcalá et al., 2011) to more than 1000 square kilometres for a major karst spring (e.g. Fontaine de Vaucluse, Fleury et al., 2007).

For the quantification of water balance components and investigation of karst system processes, environmental tracers (e.g. isotopes, ions, temperature) can be highly useful. Those natural or 
anthropogenic tracers can often be conveniently measured at the input and output compartments of the system. At karst springs certain environmental tracer signals are termed physicochemical parameters, for example the frequently measured parameter electrical conductivity.

The rapid flow and transport dynamics of karst aquifers in contrast to granular aquifers are often not adequately considered in terms of groundwater quality monitoring. Pollutants and indicators for an anthropogenic influence on the groundwater need to be monitored, especially in catchments influenced by urban, agricultural, and industrial activities. Since karst spring water is usually a mixture of the whole catchment, springs are regarded as the preferential monitoring points in karst systems (Quinlan et al., 1991; White, 2002; Bakalowicz, 2005). Few guidebooks deal with monitoring aspects of karstified carbonate aquifers (e.g. Quinlan, 1989). In the UNEP/UNESCO/WHO/WMO guidebooks (Allard, 1992; Chapman, 1996), karst aquifers are explicitly considered and regarded as "underground rivers". Accordingly, they are proposed to be sampled like rivers with a minimum frequency of 24 times per year, compared to 1-4 samples per year for non-karstified aquifers (Allard, 1992). Nevertheless, even this "high" sampling frequency may be considerably too low for catchments characterised by rapid flow dynamics (e.g. Ryan and Meiman, 1996). On the opposite end of the timescale, especially in (semi-)arid environments, precipitation and consequently groundwater recharge can display a large interannual or even inter-decadal temporal and spatial variability (e.g. Dünkeloh and Jacobeit, 2003; Xoplaki et al., 2004). Therefore, two basic aspects of a hydrometric and hydrochemical monitoring schemes need to be considered:

(1) A long-term monitoring scheme is required, covering many decades in order not to be biased by extended dry and wet periods and to include exceptional (low probability of occurrence) precipitation and draught events (Van Lanen and Carrillo-Rivera, 1998). Long records enable the recognition of long-term trends and provide the context for the interpretation of short-term highfrequency data (Burt et al., 2011). Long-term schemes are often conducted at low measurement frequencies (e.g. biweekly, monthly or even annual measurement intervals for groundwater parameters).

(2) The acquisition of highly dynamic events and the recognition of processes operating on a short timescale require a high measurement frequency (e.g. Kirchner, 2004). The adequate sampling frequency depends on the variability of the system and may be anything between minutes and ca. one day.

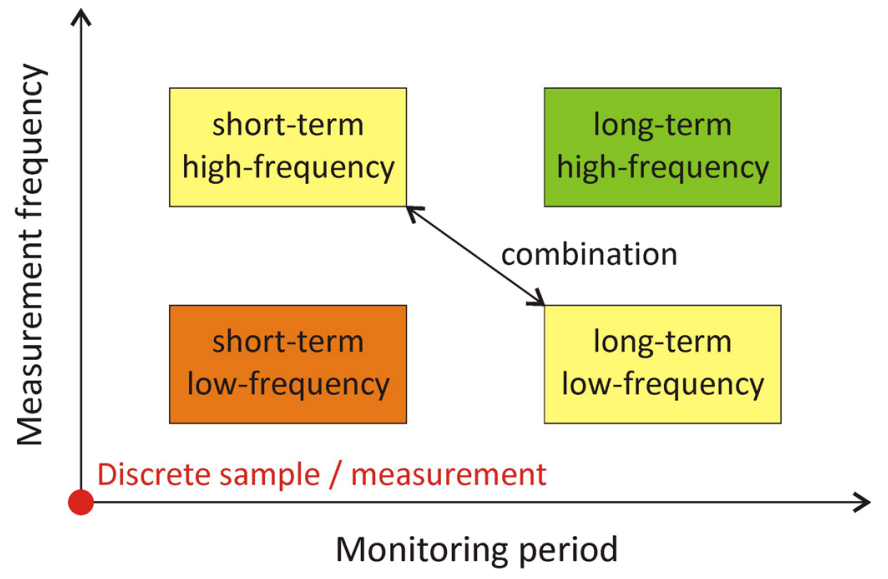

Fig. 1.4: Timescales of hydrological monitoring. 
Ideally, the high-frequency monitoring is conducted in a quasi-continuous way (Fig. 1.4). However, this can only be accomplished for parameters, which can be automatically measured using sensors and data logger systems, for example precipitation or temperature. Alternatively, a combination of a continuous low-frequency monitoring scheme and a high-resolution monitoring program for dynamic events is recommended (e.g. Ryan and Meiman, 1996).

\section{I.3.2 Determination of natural (background) groundwater quality}

Background (or baseline) groundwater quality is a concept that has gained increased attention with current legislation in the European Union (EU, 2000, 2006), which aims at the conservation of a good chemical status of groundwater or its restoration in case of already existent pollution. Different techniques may be used to assess the natural background concentration of a specific dissolved substance (e.g. ion) for a groundwater body (Table 1.1).

Table 1.1: Methods for the determination of the natural background concentration of dissolved substances in contaminated groundwater. Compiled after Panno et al. (2006), Edmunds and Shand (2008), Griffioen et al. (2008), Kelly and Panno (2008), Mendizabal et al. (2012), and own considerations.

\begin{tabular}{|c|c|}
\hline Method & Considerations and limitations \\
\hline \multirow[t]{2}{*}{ Use of historical data } & - data usually not available \\
\hline & - usually restricted to a few groundwater components \\
\hline \multirow[t]{2}{*}{ Statistical analysis of large data sets } & - problematic definition of threshold values \\
\hline & - data integrity issues \\
\hline $\begin{array}{l}\text { Extrapolation from "pristine" } \\
\text { aquifer sections }\end{array}$ & $\begin{array}{l}\text { - hydrogeochemical uniqueness of groundwater body may prevent } \\
\text { extrapolation }\end{array}$ \\
\hline 1. Data exclusion criterion & - requires analysis of groundwater residence time tracers, e.g. tritium \\
\hline groundwater age (recent groundwater) & $\begin{array}{l}\text { - different composition (e.g. due to groundwater recharge conditions, } \\
\text { rock-water interaction etc.) possible for "old" groundwater }\end{array}$ \\
\hline 2. Data exclusion criterion & • e.g. threshold for $\mathrm{NO}_{3}^{-}>10 \mathrm{mg} \mathrm{l}^{-1}$ (Wendland et al., 2006) \\
\hline agricultural contamination & - e.g. combined threshold for $\mathrm{NO}_{3}^{-}$and $\mathrm{SO}_{4}{ }^{2-}$ (Griffioen et al., 2008) \\
\hline
\end{tabular}

The use of historical data is based on the assumption that those data represent values prior to considerable human influence (Panno et al., 2006). It is the only direct and hence generally regarded as the best available technique (Edmunds and Shand, 2008; Griffioen et al., 2008; Mendizabal et al., 2012). It was, for example, applied to determine background nitrate concentration in temperate humid karst aquifers (e.g. Limbrick, 2003). Statistical approaches provide a concentration range for a larger groundwater body, i.e. they average background concentrations over larger areas. This is regarded problematic in cases of a geographically variable background concentration (Kelly and Panno, 2008). Statistical approaches were likewise applied to karst aquifers (e.g. Wendland et al., 2005; Panno et al., 2006). Further caution must be applied for the definition of statistical threshold values, for example in case of widespread contamination, in order not to include contaminated samples into the background population: "There are no a priory reasons why the upper $2-10 \%$ of the data population should include all the non- 
baseline samples" (Edmunds and Shand, 2008, p. 17). They further state: "At the practical level, the baseline needs to relate to a specific water body and values related to the controlling geochemical processes and heterogeneity involved." (p. 18). Therefore, process based approaches, such as extrapolation methods (sensu spatial background values, Kelly and Panno, 2008) are preferred to statistical approaches (Griffioen et al., 2008).

\section{I.3.3 Study site selection and description}

For reasons highlighted in the following section, the western margin of the Lower Jordan Valley located in the Levant (Eastern Mediterranean region) was selected as study region. From a hydrogeological point of view, the Levant is predominantly a carbonate karst region. Karst aquifers comprise major groundwater resources, extensively used for drinking water supply including the major cities in the region like Beirut, Damascus, and Jerusalem (e.g. Abusaada, 2011; Al-Charideh, 2012; Bakalowicz et al., 2008; Doummar, 2012; Rimmer and Salingar, 2006, Sheffer et al., 2010). Those aquifers naturally discharge via large karst springs (e.g. Fig. 1.5). In a number of cases nowadays significant amounts are abstracted by wells, i.e. the aquifers are in a state of active management (e.g. Abusaada, 2011). In contrast, in the study area, the hydrogeological units comprising the spring aquifer system are largely not affected by active management. Therefore, the natural quantitative system behaviour can be investigated.

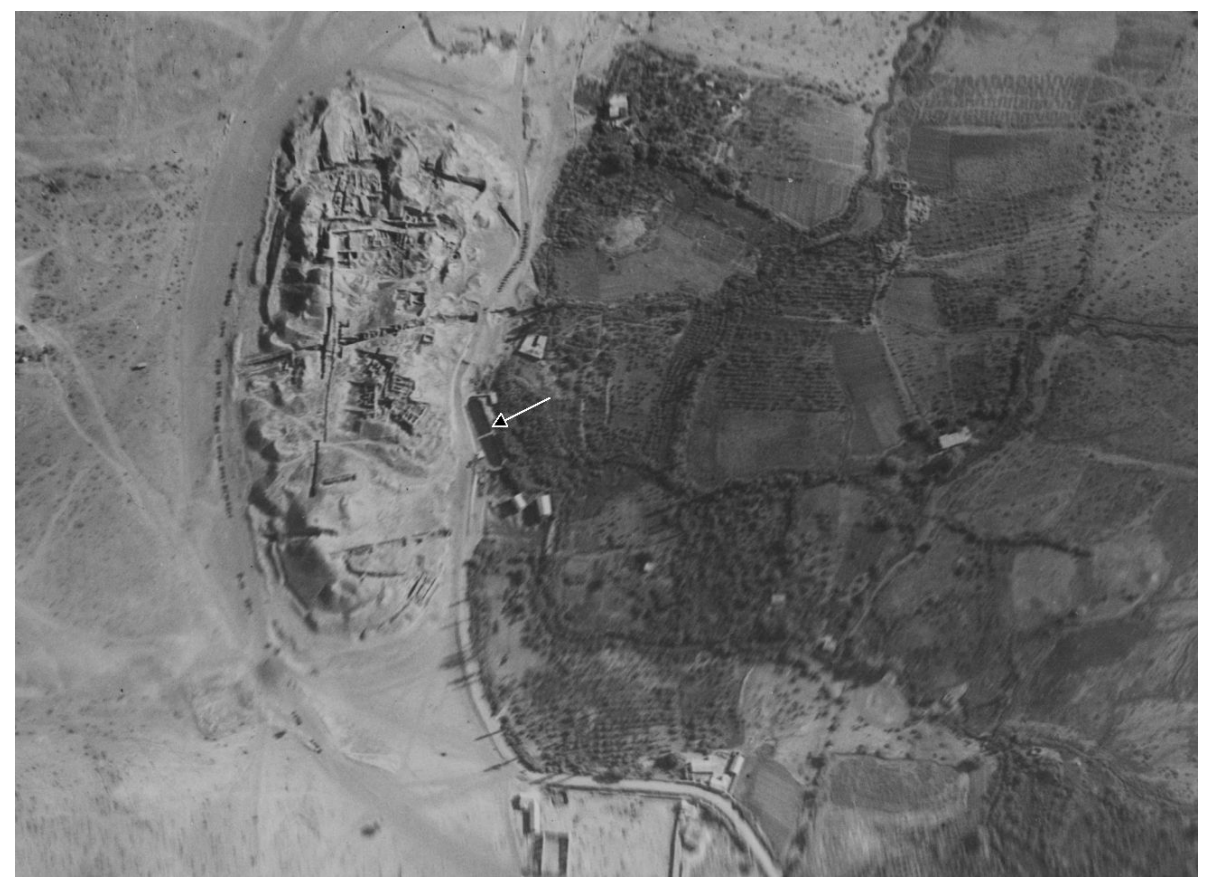

Fig. 1.5: Detail of an aerial photograph of Jericho from May 1918. Photograph approximately oriented. The oval mound in the West is the site of the ancient Jericho, Tell es-Sultan. Its north-south extent is about $350 \mathrm{~m}$. The split spring pool of Sultan spring is indicated by an arrow. To the East of the spring, the plantations of Jericho are located, which are irrigated from its water. Photograph obtained by "Bayerische Fliegerabteilung 304" (Bavarian flying squadron 304), reprinted with friendly permission of Bayerisches Hauptstaatsarchiv (Bavarian State Archives), Signatur: BS-Palästina 1031a, München, Germany.

The study area proper extends from the central mountain range of the West Bank and Israel, where the recharge area is located, down to the Lower Jordan Valley. The mountain range 


\section{Introduction}

constitutes the groundwater divide between the Mediterranean basin and the endorheic Dead Sea basin. The springs in the arid Jordan Valley are supplying oases. The most prominent example is the oasis of Jericho, supplied by the Sultan (Elisha) spring, which is inhabited since the Stone Age (Kenyon, 1957; Fig. 1.5). To date, Sultan spring is the only drinking water source of Jericho. Due to thick vadose zones and the presence of aquitards in the carbonate rock sequence as well as large scale faults, folds and monoclines, the groundwater flow system is very complex: A multilayered aquifer system is developed exhibiting a high hydraulic head gradient from the recharge zone to the discharge area. The flow system is not characterised and the groundwater catchment areas for individual springs and groundwater abstraction wells are not delineated. Furthermore, strong urbanisation of parts of the recharge areas is expected to induce considerable impacts on water quality.

In contrast to the central and western parts of the Mediterranean basin, climate in the southern Levant is characterised by an extended dry summer season (e.g. Dünkeloh and Jacobeit, 2003). Often during six or more summer months no (significant) precipitation occurs (Fig. 1.6, Jerusalem as an example). Mean annual precipitation in Jerusalem is about $530 \mathrm{~mm}$, however with large interannual and long-term differences. Often dry and wet years form "clusters" (Fig. 1.6). This phenomenon was termed "Josef effect" by Mandelbrot and Wallis (1968) and is also visible in the data of Figure 1.6. For example, during the 1950s and 1960s, six years with a mean precipitation close to the long-term average are followed by six years with $66 \%$ of the average, followed by six years with $115 \%$ (in comparison, the classical biblical scheme proposes a 7-year cluster width).

During the short winter season, the bulk amount of precipitation stems from short but intensive rainstorms. In the example hydrological year 1995/1996 about $75 \%$ of the annual precipitation occurred during five large storms (Fig. 1.6). The highest measured daily rainfall amounts are around $100 \mathrm{~mm}$ (data: http://eca.knmi.nl). An analysis of the 60 -year time series reveals that $50 \%$ of the annual precipitation was in average due to the seven rainiest days per year only. Precipitation in the hilly region around Jerusalem is predominantly by cold front showers (Goldreich, 1994). Therefore, a spatially quite homogeneous precipitation over the recharge area of the aquifer system is expected. In contrast, in other semi-arid regions, considerable fractions of precipitation are constituted by convective storms (e.g. Southern Spain ca. 50\%, Alcalá et al., 2011), which are usually characterised by a higher spatial heterogeneity. In sum, due to the precipitation characteristics in the study area, temporally sharp and spatially homogenous recharge input signals are expected, alternating with extended dry periods. These "ideal" signals in combination with a large interannual variability are believed to provide excellent conditions for a system analysis.

Partly explained by the historical attraction of the region, hydrologic investigations were conducted since the $19^{\text {th }}$ century, for example regarding continuous precipitation measurement (e.g. Rosenan, 1955). The aquifer system towards the Jordan Valley was investigated since the first half of the $20^{\text {th }}$ century (e.g. Blake and Goldschmidt, 1947). Therefore, in the study region a number of long-term monitoring data are available. Previous hydrogeological studies employed predominantly the following methods:

- Water budget calculations and numerical modelling: Due to unknown spring catchment boundaries, those studies usually comprised large parts or the carbonate aquifer system (e.g. Goldschmidt, 
1959, ca. $1000 \mathrm{~km}^{2}$ ). Later studies combined water budget calculations with transient numerical groundwater modelling (e.g. Guttman and Zuckermann, 1995). A main result of these studies is the development of empirical equations for the calculation of recharge from yearly precipitation sums.

- Environmental tracer investigations: Those investigations included the stable and radioactive isotopes of oxygen, hydrogen, carbon, and uranium (e.g. Gat and Dansgaard, 1972; Rosenthal and Kronfeld, 1982; Kroitoru, 1987; Lange, 2012). Outcomes of those studies are for example the classification of spring and well groundwater to different subsections of the carbonate aquifer complex as well as the mean residence time of modern groundwater in the aquifer systems.

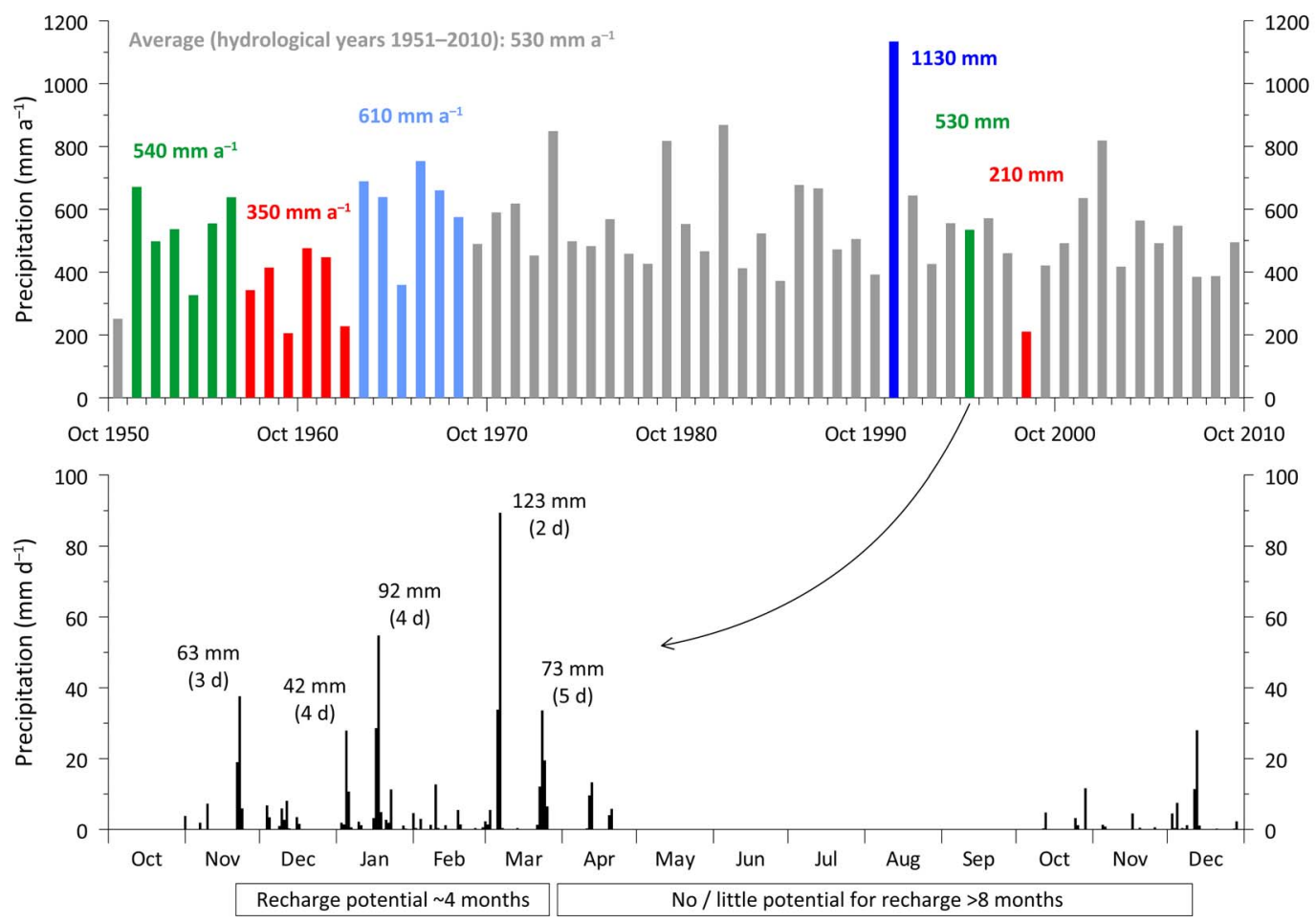

Fig. 1.6: 60-year annual precipitation time series measured at Jerusalem meteorological station (Israel Meteorological Service) along with an example for an "average" precipitation year (1995/1996). Data from the European Climate Assessment and Dataset (http://eca.knmi.nl; Klein Tank et al., 2002).

\section{I.4 Research approach and outline of the thesis}

The main objective of the thesis is the characterisation of karstified carbonate aquifers in the semiarid climate zone at the catchment scale. A thorough hydrogeological characterisation is the basis for a sophisticated assessment, development, management, and protection of groundwater resources. Those are pending applied problems in many (semi-)arid environments, especially in developing countries (e.g. Schwartz, 2013). Fundamental quantitative and qualitative factors such as the groundwater recharge rate, aquifer parameters, flow- and transport dynamics, anthropogenic impacts, and the vulnerability of groundwater to pollution need to be assessed. In many semi-arid karst environments these tasks are challenging because (1) of the general low 


\section{Introduction}

degree of hydrogeological system investigation and understanding (e.g. data scarcity, nondelineated catchment boundaries, unknown flow systems) and (2) various large scale anthropogenic and geogenic impacts on the systems (e.g. overexploitation, salinisation, pollution).

Albeit the challenges, semi-arid climates may offer specific opportunities regarding signal interpretation (e.g. due to precipitation characteristics leading to clear-cut input signals, compare previous section). System characteristics and parameters are expected to be better distinguished and derived compared to analysing the more "blurred" signals in the temperate humid counterparts. For highly variable systems, signal interpretation needs to be based on high-resolution hydrological data (e.g. Kirchner at al., 2004). In a subsequent paper, Kirchner (2006, p. 2) states: "From the growing volume and sophistication of hydrological theorizing over the past several decades, one might lose sight of the fact that the ultimate source of hydrological information is field observations and measurements." I fully agree with this statement. However, especially in semi-arid karst environments the up to date collection of high-resolution data is restricted to a few studies (e.g. Amiel et al., 2010).

Consequently, in this thesis the focus is on applied research integrating various methods, based on an extensive database of long-term and high-frequency hydrologic data. It is aimed at the development and application of sophisticated methods kept as simple as possible, in order to facilitate their application in further (semi-arid) karst aquifer systems. Specific emphasis was placed on the estimation of groundwater recharge (in both, long-term and high-resolution) and the determination of groundwater recharge processes. As a further output of the study, a monitoring and characterisation strategy for semi-arid karst aquifers was developed. The thesis has a cumulative structure and is organised into the following chapters:

Chapter 2 documents the setup of the high-resolution hydrometric monitoring network, which provides the main database for the subsequent investigations.

Chapter 3 provides the quantification of long-term mean groundwater recharge and anthropogenic impacts for a number of individual spring catchments based on long-term low-frequency hydrochemical data.

Chapter 4 focuses on the assessment of the dynamic hydraulic aquifer behaviour, aquifer system parameters, and temporal recharge variability for an exemplary spring catchment. Long-term low-frequency and high-frequency data are analysed by hydrogeological methods and a mathematical modelling approach.

Chapter 5 provides an analysis of the highly dynamic hydraulic and hydrochemical response of the spring aquifer system (four selected springs) to intensive precipitation events, in order to deduce groundwater recharge processes and to evaluate spring source vulnerability.

Chapter 6 provides a comparison and evaluation of the different investigation methodologies, a guideline for a monitoring and characterisation strategy, and an outlook for further research.

The text of the individual chapters was in places slightly modified from the originally published versions, e.g. in order to provide a consistent nomenclature and numbering of chapters, figures, tables, and references. Please also note that a separate reference list is provided at the end of each chapter. 


\section{References}

Abusaada, M., 2011. Flow dynamics and management options in a stressed carbonate aquifer system, the western aquifer basin, Palestine. PhD thesis, University of Göttingen, Göttingen. <http://hdl.handle.net/11858/001735-0000-0006-B2FD-2>.

Aeschbach-Hertig, W., Gleeson, T., 2012. Regional strategies for the accelerating global problem of groundwater depletion. Nature Geoscience 5, 853-861.

Alcalá, F.J., Cantón, Y., Contreras, S., Were, A., Serrano-Ortiz, P., Puigdefábregas, J., Solé-Benet, A., Custodio, E., Domingo, F., 2011. Diffuse and concentrated recharge evaluation using physical and tracer techniques: Results from a semi-arid carbonate massif aquifer in southeastern Spain. Environmental Earth Sciences $62,541-557$.

Al-Charideh, A., 2012. Recharge rate estimation in the mountain karst aquifer system of Figeh spring, Syria. Environmental Earth Sciences 65, 1169-1178.

Allard, M. (Ed.), 1992. GEMS/WATER operational guide, 3rd edition. UNEP/WHO/UNESCO/WMO programme on global water quality monitoring and assessment, Burlington.

Amiel, R.B., Grodek, T., Frumkin, A., 2010. Characterization of the hydrogeology of the sacred Gihon Spring, Jerusalem: a deteriorating urban karst spring. Hydrogeology Journal 18, 1465-1479.

Andreu, J.M., Alcalá, F.J., Vallejos, A. , Pulido-Bosch, A., 2011. Recharge to mountainous carbonated aquifers in SE Spain: Different approaches and new challenges. Journal of Arid Environments 75, 1262-1270.

Appelo, C.A.J., Postma, D., 2005. Geochemistry, groundwater and pollution, 2nd edition. Balkema, Leiden.

Atkinson, T.C., 1977. Diffuse flow and conduit flow in limestone terrain in the Mendip Hills, Somerset (Great Britain). Journal of Hydrology 35, 93-110.

Bakalowicz, M., 2005. Karst groundwater: a challenge for new resources. Hydrogeology Journal 13, 148-160.

Bakalowicz, M., El Hakim, M., El-Hajj, A., 2008. Karst groundwater resources in the countries of eastern Mediterranean: the example of Lebanon. Environmental Geology 54, 597-604.

Blake, G.S., Goldschmidt, M.J., 1947. Geology and water resources of Palestine. Government Printer, Jerusalem.

Burt, T.P., Howden, N.J.K., Worrall, F., McDonnel, J., 2011. On the value of long-term, low-frequency water quality sampling: avoiding throwing the baby out with the bathwater. Hydrological Processes 25, 828-830.

Butscher, C., Huggenberger, P., 2008. Intrinsic vulnerability assessment in karst areas: a numerical modeling approach. Water Resources Research 44, W03408, doi:10.1029/2007WR006277.

Chapman, D. (Ed.), 1996. Water quality assessments - a guide to use of biota, sediments and water in environmental monitoring, 2nd edition. UNESCO/WHO/UNEP, E\&FN Spon, London.

Custodio, E., 2002. Aquifer overexploitation: what does it mean?. Hydrogeology Journal 10, $254-277$.

Daly, D., Dassargues, A., Drew, D., Dunne, S., Goldscheider, N., Neale, S., Popescu, I.C., Zwahlen, F., 2002. Main concepts of the "European Approach" for karst-groundwater-vulnerability assessment and mapping. Hydrogeology Journal 10, 340-345.

Doummar, J., 2012. Identification of indicator parameters for the quantitative assessment of vulnerability in karst aquifers. PhD thesis, University of Göttingen, Göttingen. <http://hdl.handle.net/11858/00-1735-0000000D-F07C-8>. 


\section{Introduction}

Doummar, J., Sauter, M., Geyer, T., 2012. Simulation of flow processes in a large scale karst system with an integrated catchment model (Mike She) - Identification of relevant parameters influencing spring discharge. Journal of Hydrology 426-427, 112-123.

Dünkeloh, A., Jacobeit, J., 2003. Circulation dynamics of Mediterranean precipitation variability $1948-98$. International Journal of Climatology 23, 1843-1866.

Edmunds, W.M., Shand, P., 2008. Groundwater baseline quality. In: Edmunds, W.M., Shand, P. (Eds.), Natural groundwater quality. Blackwell Publishing, Malden, pp. 1-21.

EU, 2000. Water framework directive, 2000, Directive 2000/60/EC of the European parliament and the council of 23 October 2000. Establishing a framework for community action in the field of water policy. In: European Commission (Ed.), Official Journal of the European Communities, pp. L 327/1.

EU, 2006. Groundwater directive, 2006, directive 2006/118/EC of the European parliament and the council of 12 December 2006. On the protection of groundwater against pollution and deterioration. In: European Commission (Ed.), Official Journal of the European Union, pp. L 372/19.

Fleury, P., Plagnes, V., Bakalowicz, M., 2007. Modelling of the functioning of karst aquifers with a reservoir model: application to Fontaine de Vaucluse (south of France). Journal of Hydrology 345, 38-49.

Ford, D., Williams, P., 2007. Karst hydrogeology and geomorphology. Wiley, Chichester.

Foster, S.S.D., Chilton, P.J., 2003. Groundwater: the processes and global significance of aquifer degradation. Philosophical Transactions of the Royal Society of London B 358, 1957-1972.

Foster, S., Hirata, R., Andreo, B., 2013. The aquifer pollution vulnerability concept: aid or impediment in promoting groundwater protection?. Hydrogeology Journal 21, 1389-1392.

Freeze, R.A., Cherry, J.A., 1979. Groundwater. Prentice-Hall, Englewood Cliffs.

Gat, J.R., Dansgaard, W., 1972. Stable isotope survey of the fresh water occurrences in Israel and northern Jordan Rift Valley. Journal of Hydrology 16, 171-212.

Gee, G.W., Hillel, D., 1988. Groundwater recharge in arid regions: review and critique of estimation methods. Hydrological Processes 2, 255-266.

George, A.I., 1989. Caves and drainage north of the Green River. In: White, W.B., White, E.L. (Eds.), Karst hydrology - Concepts from the Mammoth Cave area. Van Nostrand Reinhold, New York, pp. 189-221.

Geyer, T., 2008. Process-based characterisation of flow and transport in karst aquifers at catchment scale. PhD thesis, University of Göttingen, Göttingen. <http://hdl.handle.net/11858/00-1735-0000-0006-B276-E>.

Goldreich, Y., 1994. The spatial distribution of annual rainfall in Israel - A review. Theoretical and Applied Climatology 50, 45-59.

Goldscheider, N., 2002. Hydrogeology and vulnerability of karst systems: Examples from the Northern Alps and the Swabian Alb. PhD thesis, University of Karlsruhe, Karlsruhe. <http://digbib.ubka.unikarlsruhe.de/volltexte/1812002>.

Goldscheider, N., 2010. Delineation of spring protection zones. In: Kresic, N., Stevanovic, Z. (Eds.), Groundwater hydrology of springs-engineering, theory, management, and sustainability. Butterworth-Heinemann, Burlington, pp. 305-338.

Goldschmidt, M.J., 1959. On the water balances of several mountain underground water catchments in Israel and their flow patterns. Hydrological Service, Hydrological Paper No. 4, Jerusalem.

Griffioen, J., Passier, H.F., Klein, J., 2008. Comparison of selection methods to deduce natural background levels 
for groundwater units. Environmental Science and Technology 42, 4863-4869.

Gunn, J., 1983. Point-recharge of limestone aquifers-A model from New Zealand karst. Journal of Hydrology 61, 19-29.

Guttman, J., Zuckerman, H., 1995. Flow model in the eastern basin of the Judea and Samaria hills. Tahal Consulting Engineers Ltd., Report No. 01/95/66, Tel Aviv. (in Hebrew).

Hartmann, A., Lange, J., Vivó Aguado, A., Mizyed, N., Smiatek, G., Kunstmann, H., 2012. A multi-model approach for improved simulations of future water availability at a large Eastern Mediterranean karst spring. Journal of Hydrology 468-469, 130-138.

Healy, R.W., Cook, P.G., 2002. Using groundwater levels to estimate recharge. Hydrogeology Journal 10, 91-109.

Healy, R.W., 2010. Estimating groundwater recharge. Cambridge University Press, Cambridge.

Herczeg, A.L., Leaney, F.W., 2011. Review: Environmental tracers in arid-zone hydrology. Hydrogeology Journal $19,17-29$.

Hogan, J.F., Phillips, F.M., Scanlon, B.R. (Eds.), 2004. Groundwater recharge in a desert environment: The Southwestern United States. Water Science and Application 9. American Geophysical Union, Washington DC.

Hötzl, H., 1996. Grundwasserschutz in Karstgebieten. Grundwasser 1, 5-11.

Jennings, J.N., 1985. Karst geomorphology. Blackwell, Oxford.

Kelly, W.R., Panno, S.V., 2008. Some considerations in applying background concentrations to ground water studies. Ground Water 46, 790-792.

Kenyon, K.M., 1957. Digging up Jericho. Ernest Benn, London.

Kinzelbach, W., Aeschbach, W., Alberich, C., Goni, I.B., Beyerle, U., Brunner, P., Chiang, W., Rueedi, J., Zoellmann, K., 2002. A survey of methods for groundwater recharge in arid and semi-arid regions. Early warning and assessment report UNEP/DEWA/RS 2(2), United Nations Environment Programme, Nairobi.

Király, L., 2002. Karstification and groundwater flow. In: Gabrovšek, F., (Ed.), Evolution of karst: from prekarst to cessation. Založba ZRC, Ljubljana, pp. 155-190.

Kirchner, J.W., Feng, X., Neal, C., Robson, A.J., 2004. The fine structure of water-quality dynamics: the (highfrequency) wave of the future. Hydrological Processes 18, 1353-1359.

Kirchner, J.W., 2006. Getting the right answers for the right reasons: linking measurements, analyses, and models to advance the science of hydrology. Water Resources Research 42, W03S04, doi:10.1029/2005WR004362.

Klein Tank, A.M.G., Wijngarrd, J.B., Konnen, G.P., Bohm, R., Demaree, A., Gocheve, M., Mileta, S., Pashiardis, L., Hejkrlik, C., Kern-Hansen, R., Heino, P., Bessemoulin, G., Muller-Westermeier, G., Tzanakou, M., Szalai, S., Palsdottir, D., Fitzgerald, D., Rubin, S., Capaldo, M., Maugeri, M., Leitass, A., Bukantis, A., Aberfeld, R., van Engelen, A.F.V., Forland, E., Mietus, M., Coelho, F., Mares, C., Razuvaev, V., Nieplova, E., Cegnar, T., López, J.A., Dahlstrom, B., Moberg, A., Kirchhofer, W., Ceylan, A., Pachaliuk, O., Alexander, L.V., Petrovic, P., 2002. Daily dataset of 20th-century surface air temperature and precipitation series for the European Climate Assessment. International Journal of Climatology 22, 1441-1453.

Kottek, M., Grieser, J., Beck, C., Rudolf, B., Rubel, F., 2006. World map of Köppen-Geiger climate classification updated. Meteorologische Zeitschrift 15, 259-263.

Kovács, A., Sauter, M., 2007. Modelling karst hydrodynamics. In: Goldscheider, N., Drew, D. (Eds.), Methods in karst hydrogeology, Taylor \& Francis, London, pp. 201-222. 


\section{Introduction}

Kresic, N., 2013. Water in karst-management, vulnerability, and restoration. McGraw-Hill, New York.

Kroitoru, L., 1987. The characterization of flow systems in carbonatic rocks defined by the ground water parameters: Central Israel. PhD thesis, Weizmann Institute of Science, Rehovot.

Lange, T., 2012. Tracing flow and salinization processes at selected locations of Israel and the West Bank - the Judea Group aquifer and the shallow aquifer of Jericho. PhD thesis, Freiberg Online Geosciences 31. $<$ http://tu-freiberg.de/geo/fog>.

Lerner, D.N., Issar, A., Simmers, I., (Eds.) 1990. Groundwater recharge: a guide to understanding and estimating natural recharge. IAH, International Contributions to Hydrogeology 8, Heise, Hannover.

Liedl, R., Sauter, M., Hückinghaus, D., Clemens, T., Teutsch, G., 2003. Simulation of the development of karst aquifers using a coupled continuum pipe flow model. Water Resources Research 39(3), 1057, doi:10.1029/2001WR001206.

Limbrick, K.J., 2003. Baseline nitrate concentration in groundwater of the Chalk in south Dorset, UK. The Science of the Total Environment 314-316, 89-98.

Mandelbrot, B.B., Wallis, J.R., 1968. Noah, Joseph, and operational hydrology. Water Resources Research 4, 909918.

Mangin, A., 1975. Contribution à l'étude hydrodynamique des aquifères karstiques-troisième partieconstitution et fonctionnement des aquifères karstiques. Annales de Spéléologie 30, 21-124.

Marei, A., Khayat, S., Weise, S., Ghannam, S., Sbaih, M., Geyer, S., 2010. Estimating groundwater recharge using the chloride mass-balance method in the West Bank, Palestine. Hydrological Sciences Journal 55, 780791.

Martínez-Santos, P., Andreu, J.M., 2010. Lumped and distributed approaches to model natural recharge in semiarid karst aquifers. Journal of Hydrology 388, 389-398.

Martos-Rosillo, S., Rodríguez-Rodríguez, M., Pedrera, A., Cruz-SanJulián, J.J., Rubio, J.C., 2013. Groundwater recharge in semi-arid carbonate aquifers under intensive use: the Estepa Range aquifers (Seville, southern Spain). Environmental Earth Sciences 70, 2453-2468.

Mendizabal, I., Baggelaar, P.K., Stuyfzand, P.J., 2012. Hydrochemical trends for public supply well fields in the Netherlands (1898-2008), natural backgrounds and upscaling to groundwater bodies. Journal of Hydrology 450-451, 279-292.

Panno, S.V., Kelly, W.R., Martinsek, A.T., Hackley, K.C., 2006. Estimating background and threshold nitrate concentrations using probability graphs. Ground Water 44, 697-709.

Peel, M.C., Finlayson, B.L., McMahon, T.A., 2007. Updated world map of the Köppen-Geiger climate classification. Hydrology and Earth System Sciences 11, 1633-1644.

Quinlan, J.F., 1982. Ground water basin delineation with dye-tracing, potentiometric surface mapping, and cave mapping, Mammoth Cave region, Kentucky, U.S.A.. Beiträge zur Geologie der Schweiz-Hydrologie 28, 177-189.

Quinlan, J.F., 1989, Ground-water monitoring in karst terranes-recommended protocols and implicit assumptions. U.S. Environmental Protection Agency, EPA 600/X-89/050, Las Vegas, www.karstwaters.org/files/gwkarstr.pdf.

Quinlan, J.F., Smart, P.L., Schindel, G.M., Alexander Jr., E.C., Edwards, A.J., Smith, A.R., 1991. Recommended administrative/regulatory definition of karst aquifer, principles of classification of carbonate aquifers, practical evaluation of vulnerability of karst aquifers, and determination of optimum sampling frequency at springs. In: Proceedings of the third conference on hydrogeology, ecology, monitoring, and 
management of ground water in karst terranes, Nashville, pp. 573-635.

Rimmer, A., Salingar, Y., 2006. Modelling precipitation-streamflow processes in karst basin: The case of the Jordan River sources, Israel. Journal of Hydrology 331, 524-542.

Rosenan, N., 1955. One hundred years of rainfall in Jerusalem: a homotopic series of annual amounts. Israel Exploration Journal 5, 137-153.

Rosenthal, A., Kronfeld, J., 1982. ${ }^{234} \mathrm{U}-238 \mathrm{U}$ disequilibria as an aid to the hydrological study of the Judea Group aquifer in eastern Judea and Samaria, Israel. Journal of Hydrology 58, 149-158.

Ryan, M., Meiman, J., 1996. An examination of short-term variations in water quality at a karst spring in Kentucky. Ground Water 34, 23-30.

Sauter, M., 1992. Quantification and forecasting of regional groundwater flow and transport in a karst aquifer (Gallusquelle, Malm, SW. Germany). PhD thesis, Tübinger Geowissenschaftliche Arbeiten C13, Tübingen.

Scanlon, B.R., Healy, R.W., Cook, P.G., 2002. Choosing appropriate techniques for quantifying groundwater recharge. Hydrogeology Journal 10, 18-39.

Scanlon, B.R., Keese, K.E., Flint, A.L., Flint, L.E., Gaye, C.B., Edmunds, W.M., Simmers, I., 2006. Global synthesis of groundwater recharge in semiarid and arid regions. Hydrological Processes 20, 3335-3370.

Schoeller, H., 1960. Salinité des eaux souterraines, évapotranspiration et alimentation des nappes. IAHS Publication 52, 488-494.

Schwartz, F.W., 2013. Zombie-science and beyond. Ground Water 51, 1.

Sheffer, N.A., Dafny, E., Gvirtzman, H., Frumkin, A., Navon, S., Morin, E., 2010. The hydrometeorological DReAM (Daily Recharge Assessment Model) for the Israeli western mountain aquifer (WMA). Water Resources Research 46, W05510, doi:10.1029/2008WR007607.

Simmers, I., 1990. Aridity, groundwater recharge and water resources management. In: Lerner, D.N., Issar, A., Simmers, I. (Eds.), Groundwater recharge: a guide to understanding and estimating natural recharge. IAH, International Contributions to Hydrogeology 8, Heise, Hannover, pp. 1-20.

Simmers, I., 1997. Groundwater recharge principles, problems and developments. In: Simmers, I., (Ed.), Recharge of phreatic aquifers in (semi-) arid areas, Balkema, Rotterdam, pp. 1-18.

Simmers, I., (Ed.) 1997. Recharge of phreatic aquifers in (semi-) arid areas, Balkema, Rotterdam.

Stonestrom, D.A., Constantz, J., Ferré, T.P.A., Leake, S.A. (Eds.), 2007. Ground-water recharge in the arid and semiarid southwestern United States. U.S. Geological Survey Professional Paper 1703, http://pubs.usgs.gov/pp/pp1703/.

Sweeting, M.M., 1972. Karst landforms. Macmillan, London.

UNEP, 2013. The UNEP Environmental Data Explorer, as compiled from UNEP/DEWA/GRID-Geneva. United Nations Environment Programme. http://geodata.grid.unep.ch.

UNESCO, 1979. Map of the world distribution of arid regions. MAB Technical Notes 7, United Nations Educational, Scientific and Cultural Organization, Paris.

Van Lanen, H.A.J., Carrillo-Rivera, J.J., 1998. Framework for groundwater monitoring in (semi-)arid regions. In: Van Lanen, H.A.J. (Ed.), Monitoring for groundwater management in (semi-)arid regions. Studies and Reports in Hydrogeology 57, UNESCO Publishing, Paris, pp. 7-20. 


\section{Introduction}

Weiss, M., Gvirtzman, H., 2007. Estimating ground water recharge using flow models of perched karstic aquifers. Ground Water 45, 761-773.

Wendland, F., Blum, A., Kunkel, R., 2006. Approach to assess natural background levels (NBLs). In: Müller, D., Blum., A., Hart, A., Hookey, J., Kunkel, R., Scheidleder, A., Tomlin, C., Wendland, F., Final proposal for a methodology to set up groundwater threshold values in Europe. Deliverable 18, project BRIDGE, $<$ http://www.wfd-bridge.net>, pp. 26-32.

Wendland, F., Hannappel, S., Kunkel, R., Schenk, R., Voigt, H.J., Wolter, R., 2005. A procedure to define natural groundwater conditions of groundwater bodies in Germany. Water Science and Technology 51, $249-257$.

White, W.B., 1988. Geomorphology and hydrology of karst terrains. Oxford University Press, New York.

White, W.B., 2002. Karst hydrology: recent developments and open questions. Engineering Geology 65, 85-105.

Williams, P.W., 1983. The role of the subcutaneous zone in karst hydrology. Journal of Hydrology 61, 45-67.

Worthington, S.R., Smart, C.C., 2013. Determination of tracer mass for effective groundwater tracer tests. Carbonates and Evaporites, 1-8, doi: 10.1007/s13146-013-0171-4.

Xoplaki, E., Gonzalez-Rouco, J.F., Luterbacher, J.U., Wanner, H., 2004. Wet season Mediterranean precipitation variability: influence of large-scale dynamics and trends. Climate Dynamics 23, 63-78.

Xu, Y., Beekman, H.E. (Eds.), 2003. Groundwater recharge estimation in Southern Africa. UNESCO IHP Series 64, United Nations Educational, Scientific and Cultural Organization, Paris.

Zwahlen, F. (Ed.), 2004. Vulnerability and risk mapping for the protection of carbonate (karst) aquifers - Final report COST action 620. European Commission, Directorate-General for Research, Brussels. 


\section{Chapter 2}

\section{Design and setup of a high resolution hydrometric monitoring network in a semi-arid karst environment - West Bank}

Sebastian Schmidt ${ }^{1}$, Steffen Fischer ${ }^{1}$, Mathias Toll ${ }^{1}$, Fabian Ries ${ }^{2}$, Omar Zayed ${ }^{3}$, Joseph Guttman ${ }^{4}$, Amer Marei ${ }^{5}$, Menachem Weiss ${ }^{6}$, Tobias Geyer ${ }^{1}$, Martin Sauter ${ }^{1}$

Publication:

Schmidt, S., Fischer, S., Toll, M., Ries, F., Zayed, O., Guttman, J., Marei, A., Weiss, M., Geyer, T., Sauter, M., 2012. Design and setup of a high resolution hydrometric monitoring network in a semi-arid karst environment - West Bank. In: Rausch, R., Schüth, C., Himmelsbach, T. (eds.), Hydrogeology of arid environments. Borntraeger, Stuttgart, pp. 147-150.

Reprinted with friendly permission from Schweizerbart science publishers www.schweizerbart.de

\footnotetext{
${ }^{1}$ Georg-August-Universität Göttingen, Geowissenschaftliches Zentrum Göttingen, Angewandte Geologie, Goldschmidtstraße 3, 37077 Göttingen, Germany, E-Mail: sschmid1@gwdg.de

${ }^{2}$ Albert-Ludwigs-Universität Freiburg, Institut für Hydrologie, Fahnenbergplatz, 79098 Freiburg, Germany

${ }^{3}$ Palestinian Water Authority, P.O.B. 2174, Ramallah, West Bank

${ }^{4}$ Mekorot, Israel National Water Company, 9 Lincoln St., Tel Aviv 61201, Israel

${ }^{5}$ Al-Quds University, Department of Earth and Environmental Studies, P.O.B. 20002, Jerusalem, West Bank

${ }^{6}$ Hydrological Service of Israel, 234 Yafo St., P.O.B. 36118, Jerusalem 91360, Israel
} 


\section{I Introduction}

Semi-arid to arid environments are characterised by a general shortage of water resources. Surface water flow is often ephemeral and occurs only after strong precipitation events, especially in karstified landscapes with predominant subsurface drainage. Groundwater recharge displays a high spatial and temporal variability because of preferential flow pathways in the subsurface. A succession of several years with less than average precipitation can lead to a longterm decline of water resources. Compared to humid environments, often less hydrologic and hydrogeologic data are available. However, these data are a prerequisite for the system analysis, i.e. to quantify available water resources and ensure a sustainable use of those resources. To meet the specific requirements of (semi-)arid environments regarding hydrometric data assessment, an adapted design of the measuring network is demanded.

\subsection{Study area and hydrogeologic challenges}

The study area is located on the western graben shoulder of the Jordan Rift Valley northwest of the Dead Sea (West Bank). Groundwater is the main water resource in the region. The regional aquifer system is composed of karstified Cretaceous carbonate rocks with a thickness of about 800 meters. Ground level ranges from $1000 \mathrm{~m}$ above sea level in the mountain range in the west to about $400 \mathrm{~m}$ below sea level at the Jordan River and Dead Sea in the southeast (Fig. 2.1).

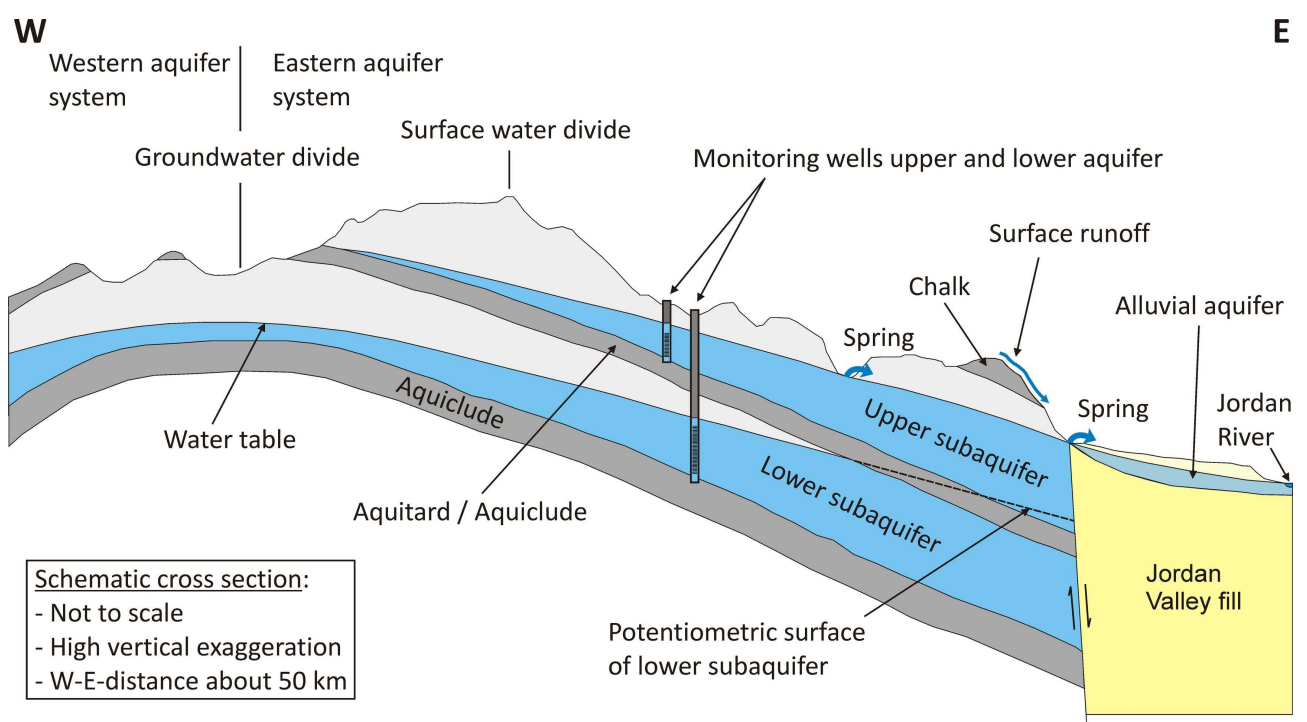

Fig. 2.1: Schematic hydrogeologic cross section through the study area. The upper and lower subaquifers are mainly composed of fractured and karstified Albian to Turonian limestone and dolomite, the aquitards and aquicludes are chiefly composed of marl and chalk. However, lateral facies changes occur, enabling local aquifer connection (ANTEA, 1998). 
The steep topographic gradient leads to an overall steep gradient in the hydraulic head distribution, however with large local differences. The mean annual precipitation ranges from about $600 \mathrm{~mm} \mathrm{a}^{-1}$ in the mountainous area in the western part to about $100 \mathrm{~mm} \mathrm{a}^{-1}$ near the Dead Sea. The recharge area of the carbonate aquifers corresponds to the outcrop area of the permeable carbonate strata and is located in the western mountainous part of the study area. Two main aquifer horizons can be distinguished. The upper aquifer discharges in the arid Jordan Valley via several springs which are the reason for oases like e.g. Jericho. The spring water is used for irrigated agriculture and domestic water supply. However, due to complex hydrogeological conditions, the catchments of the springs, the flow system of the aquifers, as well as the spatial and temporal distribution of groundwater recharge, are not yet very well described and understood. Therefore a monitoring network was designed and implemented in the area north of Ramallah and west of Jericho (Fig. 2.2).
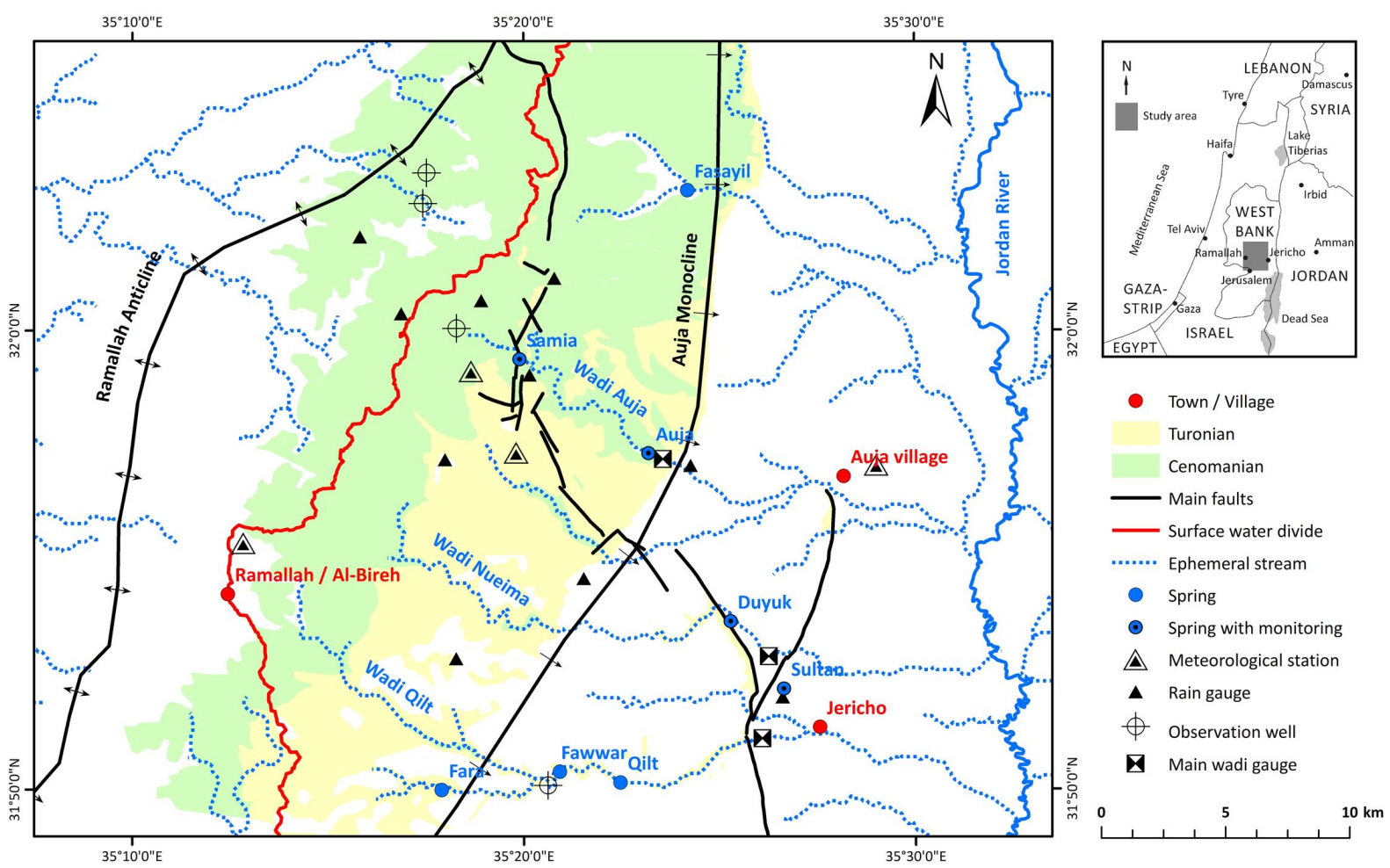

Fig. 2.2: Map of the study area with the main components of the monitoring network. The outcrop of the Cretaceous formations (= potential recharge area of springs) modified after Sneh et al. (1998).

\subsection{Setup of the monitoring network}

Flow and transport processes in the aquifer systems shall be characterised. Because of the large heterogeneity of karst systems, data with a high spatial and temporal resolution are required. Numerical models for prediction of spring discharge require time series of precipitation, spring discharge, groundwater levels, surface runoff, meteorological parameters to calculate potential evapotranspiration, and soil moisture. Physicochemical spring parameters might be used to estimate aquifer characteristics. 


\subsection{Spring gauging stations and monitoring of spring physicochemical parameters}

Emphasis is placed on the measurement of karst spring responses to precipitation. The time series of spring discharge and physicochemical parameters provide integral information about the whole groundwater catchment. For accurate long-term discharge measurements, solid gauging stations had to be constructed. This was accomplished at two main springs in the study area. Figure 2.3 displays one example. For each gauging station, a stage-discharge relation was established with discharge measurements during different flow stages. To assess time series of spring water electrical conductivity, temperature, turbidity, and $\mathrm{pH}$, multiparameter-probes were installed at four springs.
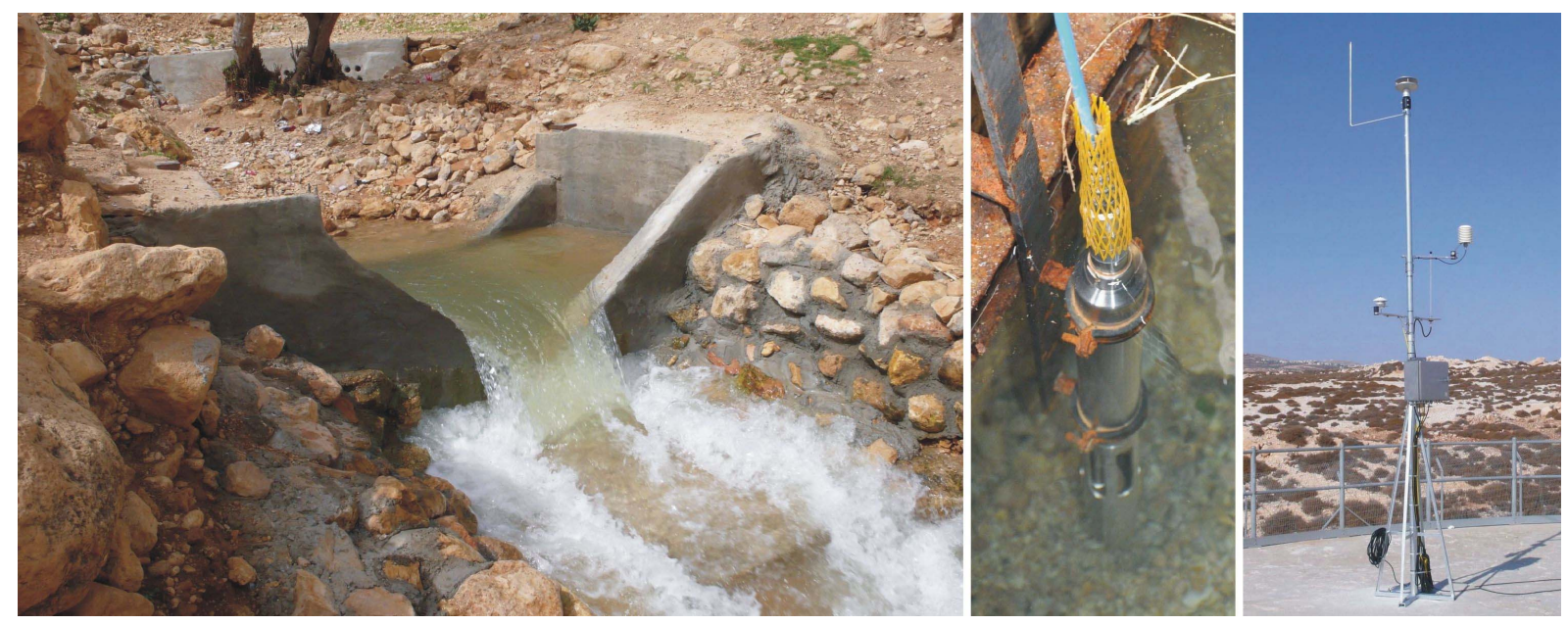

Fig. 2.3: Examples of installations: Left: spring gauging and hydrochemical parameter monitoring station at the Auja spring. The weir was constructed for the research. The spring tapping structure in the background was profoundly rehabilitated. From the structure, an underground pipe leads to the weir. In the structure, the multiparameter-probe is installed (middle). Flow at time of picture was about $5001 \mathrm{~s}^{-1}$. Right: Meteorological station on top of a water reservoir.

\subsubsection{Monitoring stations for groundwater level}

Groundwater level monitoring provides data for the assessment of groundwater flow and recharge processes, the assessment of the water percolation through the unsaturated zone and groundwater flow modelling. Four, deep groundwater wells in the carbonate aquifers were equipped with pressure transducers. At three of the wells, vandalism safe caps were installed. Well depth ranges from 150-575 m, depth to water table from 100-440 m. Therefore absolute pressure transducers attached to polypropylene ropes were installed in the wells. Close to the land surface barometric pressure transducers are installed in the wells to monitor changes in barometric pressure.

\subsubsection{Meteorological stations, rain gauges and precipitation sampling}

Meteorological instruments need to be installed at exposed but safe places. Therefore comparatively few sites are suitable. Schools, other public buildings and water supply 
infrastructure, like pump houses or elevated reservoirs turned out to be suitable sites (Fig. 2.3). In total, four meteorological stations and 11 rain gauges were installed. The meteorological stations measure time series of temperature, relative humidity, global radiation, wind speed, and precipitation. Those parameters are necessary to calculate potential evapotranspiration rate, e.g. by the Penman-Monteith method (Allen et al., 1998). The meteorological stations are aligned in a transect perpendicular to the topography, to cover the strong gradient in meteorological parameters from the mountain range down to the Jordan Valley. The rain gauge network is denser around Wadi Auja to conduct high-resolution rainfall-runoff research. Precipitation sampling for major ions and stable isotopes is conducted manually at three locations along the meteorological gradient by water authority staff, teachers and waterworks personnel.

\subsubsection{Monitoring stations for flood runoff}

Flash floods are very difficult to gauge, because of the high flow velocity and sediment load. Precalibrated structures like weirs and flumes (Bos, 1989) are preferable. Two concrete weir structures at main wadis in the region were already available, but had to be rehabilitated (one station was rehabilitated by Helmholtz Centre for Environmental Research - UFZ, Halle) and equipped with instruments for stage measurement and record. A third main wadi is gauged at a large road culvert. The main study site for rainfall-runoff processes is Wadi Auja, where six additional (sub-)catchment gauging stations were installed. The sediment load of the ephemeral flow is a major problem for stations with an insufficient sediment passing capacity. Therefore, at those sites, continuous maintenance and removal of accumulated sediment is required.

\subsubsection{Monitoring stations for soil moisture profiles}

At four places soil moisture sensors, arranged as depth profiles, were installed in combination with a data logger. Those data provide high resolution data regarding infiltration, soil water movement, soil water balance and estimates for deep percolation, hence the water that will become groundwater recharge at the water table.

\subsection{Selected results}

The Auja spring shows a fast reaction after precipitation events. For example, after a very intense precipitation event during early 2010, the spring discharge started to rise just 14 hours after the onset of the precipitation in the catchment. Discharge increased 8-fold from about $60 \mathrm{l} \mathrm{s}^{-1}$ to $480 \mathrm{l} \mathrm{s}^{-1}$ within 110 hours. Currently a period of less than average precipitation prevails. Therefore, Auja spring stops flowing during the summer. During the last three years the spring was flowing for only $30 \%$ of the time.

Despite the very stable discharge of the Sultan spring, and the very large storage of the aquifer, the spring nevertheless displays characteristics of a karst spring. Following intense precipitation 
events in the recharge area, a strong response in the physicochemical parameters can be observed. Within a few days after the onset of precipitation, an increase in turbidity followed by a strong decrease in electrical conductivity can be noted. This is an indicator, that newly recharged event water is discharged at the spring with only a short lag time.

\section{Acknowledgements}

The work is conducted within the framework of the multi-lateral research project "SMART Sustainable Management of Available Water Resources with Innovative Technologies" funded by BMBF (German Federal Ministry of Education and Research), references Nos. 02WM0802 and 02WM1081. The people and institutions contributing to the setup of the monitoring network are too numerous to be acknowledged individually. We are thankful for the help of everyone.

\section{References}

Allen, R.G., Pereira, L.S., Raes, D., Smith, M., 1998. Crop evapotranspiration: guidelines for computing crop water requirements. Irrigation and Drainage Paper 56, FAO, Rome.

ANTEA, 1998. Well development study of the Eastern Aquifer Basin, northern districts of Palestine, Volume 1: Interim report, conceptual model. Unpublished Antea report No. A11903.

Bos, M.G. (Ed.) 1989. Discharge measurement structures, 3rd ed. ILRI Publication 20, International Institute for Land Reclamation and Improvement, Wageningen.

Sneh, A., Bartov, Y., Weissbrod, T., Rosensaft, M., 1998. Geological map of Israel, 1:200,000. Geological Survey of Israel, on-line geological map, Jerusalem. <http://www.gsi.gov.il>. 


\section{Chapter 3}

\section{Quantification of long-term wastewater impacts on karst groundwater resources in a semi-arid environment by chloride mass balance methods}

Sebastian Schmidtta, ${ }^{\mathrm{a}}$, Tobias Geyera, Amer Marei ${ }^{\mathrm{b}}$, Joseph Guttmanc, Martin Sauter ${ }^{\mathrm{a}}$

Publication:

Schmidt, S., Geyer, T., Marei, A., Guttman, J., Sauter, M., 2013. Quantification of long-term wastewater impacts on karst groundwater resources in a semi-arid environment by chloride mass balance methods. Journal of Hydrology 502, 177-190.

\footnotetext{
a University of Göttingen, Geoscience Centre, Applied Geology, Goldschmidtstraße 3, 37077 Göttingen, Germany

b Al-Quds University, Department of Earth and Environmental Studies, P.O.B. 20002, Jerusalem, West Bank

c Mekorot, Israel National Water Company, 9 Lincoln St., Tel Aviv 61201, Israel

* Corresponding author. Tel.: +49 551 399333; fax: +49 551399379

E-mail address: Sebastian.Schmidt@geo.uni-goettingen.de
} 


\section{Summary}

Karst groundwater resources in semi-arid environments are highly vulnerable with respect to anthropogenic impacts, such as wastewater infiltration, because of focussed recharge and the rapid transport of dissolved substances in highly permeable conduit systems. In this study, groundwater resources of the western margin of the Lower Jordan Valley and their respective water qualities were investigated. The region is characterised by a carbonate aquifer system, which predominantly discharges via karst springs. The area experiences a large population growth and consequently a rising chloride concentration due to effluent infiltration is observed in many springs. Long-term records of chloride concentration in spring water were assembled in an extensive literature study. For some springs, larger parts of the period of 1938-2012 were covered. Chloride was used as an all-in-one environmental tracer for the objectives of (1) groundwater recharge estimation and (2) anthropogenic impact quantification. The investigations required the determination of the natural background concentration of chloride in groundwater. It was estimated by a combined use of historical data and a trend analysis for larger springs in the area and a range between 20 and $40 \mathrm{mg} \mathrm{l}^{-1}$ was found. Together with chloride concentration data for local precipitation, the long-term mean natural groundwater recharge was calculated with the chloride mass balance method. Recharge ranged between $25 \%$ and $50 \%$ of the precipitation. The proportion of wastewater-borne spring flow was quantified by a chloride end member mixing model. The springs exhibited a wastewater-borne flow fraction between $0 \%$ and $20 \%$ calculated from recent samples. The successful application of these methods underlines the value of longterm monitoring, even at a comparatively low time resolution.

\section{I Introduction}

Globally, groundwater constitutes a major source of potable water. However, it is increasingly threatened in quantity and quality (Foster and Chilton, 2003; Morris et al., 2003). For the development, management, and protection of groundwater resources, especially in semi-arid and arid regions, two fundamental prerequisites are (1) the quantification of groundwater recharge and (2) the identification and quantification of any contaminant sources.

The complexity of groundwater recharge estimation normally increases with increasing aridity of the study region, as focussed and rapid recharge is of significance in those settings (Lerner et al., 1990; Scanlon et al., 2002; Healy, 2010). The chloride mass balance (Schoeller, 1960) is the most widely applied recharge estimation method in arid to semi-arid environments (Scanlon et al., 2006). It can be applied by analysing unsaturated zone profiles of the chloride concentration or by analysing the chloride concentration in groundwater and in precipitation (e.g. Edmunds and Gaye, 1994). The accuracy of the method is often limited by the short available monitoring period of chloride concentration in precipitation and groundwater (Scanlon et al., 2006; Wood and Sanford, 1995; Edmunds and Gaye, 1994). 
The natural hydrochemical composition of groundwater is mainly a function of atmospheric input (wet and dry deposition), evapotranspiration, biogeochemical processes in the soil zone, and e.g. water-rock interaction processes in the aquifer (Appelo and Postma, 2005; Edmunds and Shand, 2008a). Groundwater quality is often affected by anthropogenic contamination sources, such as waste and wastewater disposal in the environment, sewer leakage, agricultural practices, and atmospheric deposition. Contamination can be chemical or microbiological. In view of pathogen microbial contamination, wastewater infiltration is considered especially problematic. Karstified carbonate aquifers are particularly vulnerable to pollution because of focussed infiltration and rapid contaminant transport in the phreatic zone. Furthermore, due to the usual absence of surface streams in karst environments, wastewater infiltration is often applied as a wastewater discharge method in those settings (e.g. Einsiedl et al., 2010).

To assess the health risk associated with groundwater contamination and for remediation measures planning, the wastewater impact on a groundwater resource needs to be quantified and predicted. For this purpose, the evaluation of wastewater indicator substances in groundwater is considered as a suitable technique (Katz et al., 2009; Wolf et al., 2012). Different substances have been proposed as wastewater indicators, including inorganic anions and compounds such as nitrate, chloride or boron (Vengosh and Keren, 1996; Barrett et al., 1999; Panno et al., 2006), microorganisms such as Escherichia coli (Paul et al., 2004; Katz et al., 2009), or organic substances, for example, carbamazepine, diclofenac or caffeine (Gasser et al., 2010; Einsiedl et al., 2010; Hillebrand et al., 2012). Despite the number of potential wastewater indicators, the quantification of the wastewater-borne groundwater fraction is not straightforward. For most indicator substances, especially for the trace organics, no long-term data sets are available for their occurrence in groundwater and in potential input sources, which makes it difficult to derive longterm trends about water quality (Wolf et al., 2012). Furthermore, those substances are expected to be subject to decomposition or sorption processes in the environment (e.g. Tiehm et al., 2011). Chloride exhibits well known advantages as an environmental tracer, because of its conservative behaviour in most hydrologic systems, its only minor participation in biochemical processes, and its comparatively easy analysis (e.g. Leibundgut et al., 2009). Since the chloride ion is not removed by common wastewater treatment processes, it is indicative of both treated and untreated wastewater. For the application, the natural background (baseline) concentration in groundwater has to be determined. This poses a challenge in anthropogenic influenced groundwater systems. Historical data provide a direct reference of natural concentrations (Edmunds and Shand, 2008a; Griffioen et al., 2008; Kelly and Panno, 2008). In this context, those samples are regarded as historical data which were obtained before anthropogenic influence on groundwater resources started ("pre-impact condition", Godwin et al., 2003). This date is of course site specific but often considered as the time before 1940/1945 (e.g. Griffioen et al., 2008; Mendizabal et al., 2012). However, the availability of historical data is often restricted to aquifers in temperate climate regions (e.g. Limbrick, 2003; Mendizabal et al., 2012).

In this study, chloride was considered as an all-in-one environmental tracer for the objectives of (1) regional groundwater recharge estimation and (2) anthropogenic impact quantification. Furthermore, nitrate (conservative under aerobic conditions, e.g. Edmunds and Shand, 2008a), was included as an indicator for various anthropogenic influences. The methodology is applied to a regional karstified carbonate aquifer system in a semi-arid environment. The recharge area of the system is characterised by strong urbanisation. The study involves: (1) preparation of a long- 
term database of chloride and nitrate concentrations in groundwater, local precipitation, and wastewater, (2) discussion of potential geogenic and anthropogenic chloride sources, (3) identification of anthropogenically influenced groundwater by evaluation of time series of chloride and nitrate in spring water, (4) determination of the natural background concentration of chloride in groundwater, (5) calculation of the long-term groundwater recharge rate for individual spring catchments, and (6) quantification of the wastewater derived fraction of spring discharge.

\subsection{Study area}

\subsection{Geography, climate, and surface hydrology}

The study area is located on the western margin of the Lower Jordan Valley (Fig. 3.1). The highland region in the western part of the study area has an elevation of up to $1000 \mathrm{~m}$ above mean sea level, typically around $800 \mathrm{~m}$. This region can be classified as semi-arid according to UNESCO definition (UNESCO, 1979). The mean annual precipitation measured at Jerusalem meteorological station (Israel Meteorological Service, $800 \mathrm{~m} \mathrm{ASL}$ ) was $556 \mathrm{~mm}$ for the period of 1967-2000 (data from European Climate Assessment and Dataset, Klein Tank et al., 2002). The mean air temperature during this period was $17.5^{\circ} \mathrm{C}$. The Jordan Valley in the eastern part of the study area is located below mean sea level (Dead Sea ca. $-420 \mathrm{~m}$ ASL) and is characterised by an arid climate. The drainage network of the study area is characterised by ephemeral valleys. Most of the precipitation infiltrates into the soils or directly into the outcropping rock formations, which are often karstified. Only during intensive precipitation events, surface runoff is locally generated (Rofe \& Raffety Consulting Engineers, 1965).

\subsubsection{Geology and hydrogeology}

In the study area, the predominant formations of rock outcrops are of Cretaceous and Quaternary ages (Fig. 3.1). The main aquifers are located within the Albian-Turonian strata, which display a thickness of approximately $800 \mathrm{~m}$ and are predominantly composed of limestone and dolomite (Fig. 3.3). Interbedded strata of marl and chalk form aquitards and aquicludes. The Ramallah anticline structure leads to the development of a groundwater divide (Figs. 3.1 and 3.2). Regional groundwater flow is either towards the Mediterranean Sea (Western Aquifer System) or towards the Jordan River and Dead Sea (Eastern Aquifer System). In the Jordan Valley, the Cretaceous sediments are downthrown at the western boundary fault of the Jordan Rift Valley (Figs. 3.1 and 3.2). The Jordan Valley fill consists mainly of alluvial and lacustrine sediments. The discharge of the carbonate aquifer system occurs largely via springs. Currently, considerable groundwater quantities of the Albian aquifer are abstracted via pumping wells for water supply. The springs in the study area can be classified into two groups according to their geographic location and hydrogeologic characteristics (Table 3.1). 
Table 3.1: Classification scheme for the springs in the study area. Data largely based on Nuseibeh and Nasser Eddin (1995) and Palestinian Water Authority (2000).

\begin{tabular}{lcc}
\hline Characteristics & Class 1 & Class 2 \\
\hline Number of springs $(n)$ & $36^{\mathrm{a}}$ & 8 \\
Spring elevation (m ASL) & $255-800$, typical 500-750 & $-215-440$ \\
Mean discharge $\left(1 \mathrm{l} \mathrm{s}^{-1}\right)$ & $0.1-10$, typical 0.2-1 & $20-300$ \\
\hline
\end{tabular}

a Analysed springs, for which long-term hydrological and hydrochemical time series are available.
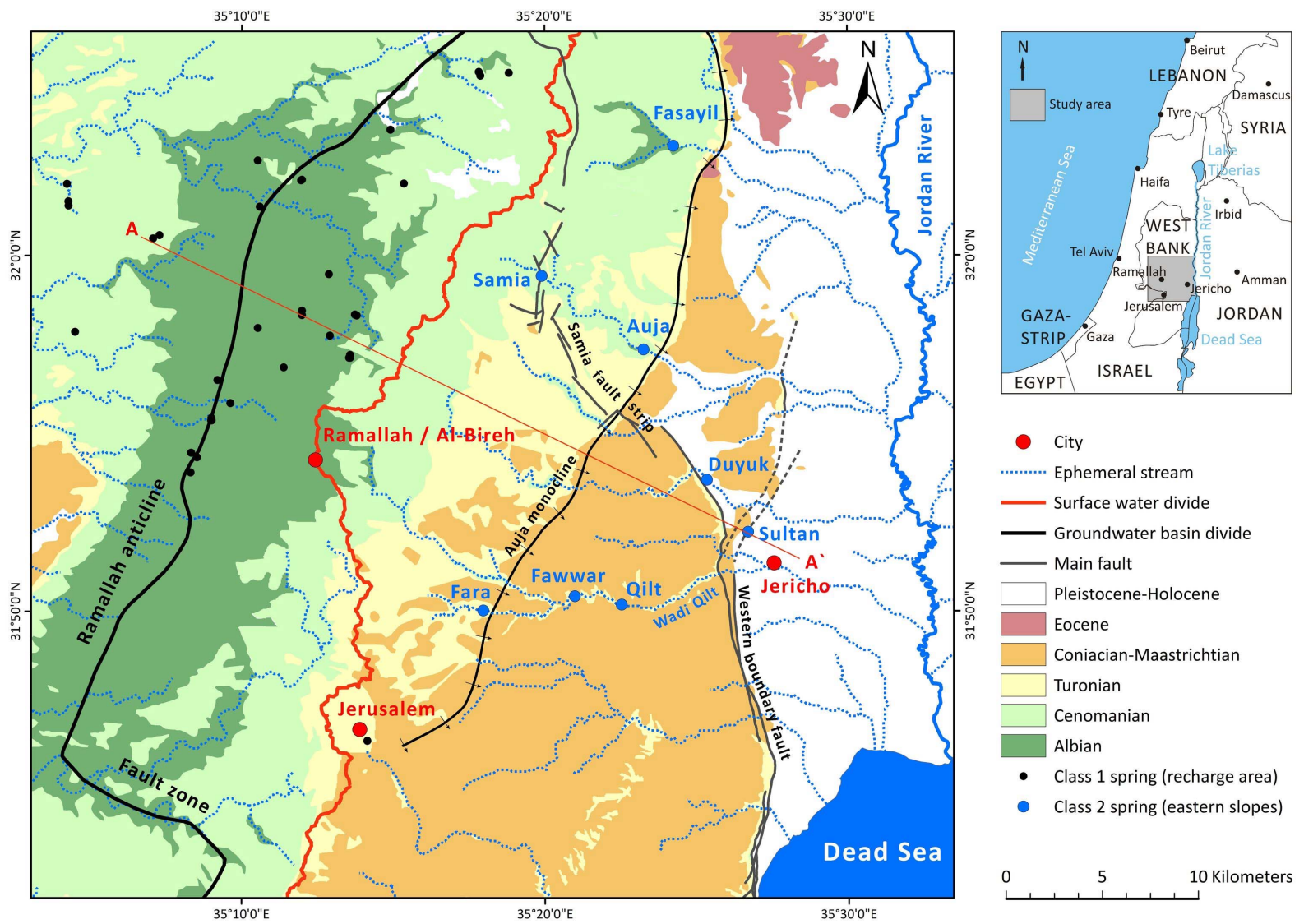

Fig. 3.1: Map of the study area displaying surface geology and the main hydrological/hydrogeological features. Outcrop areas modified after Sneh et al. (1998), groundwater divide after ANTEA (1998), Auja monocline after Lenz (1969).

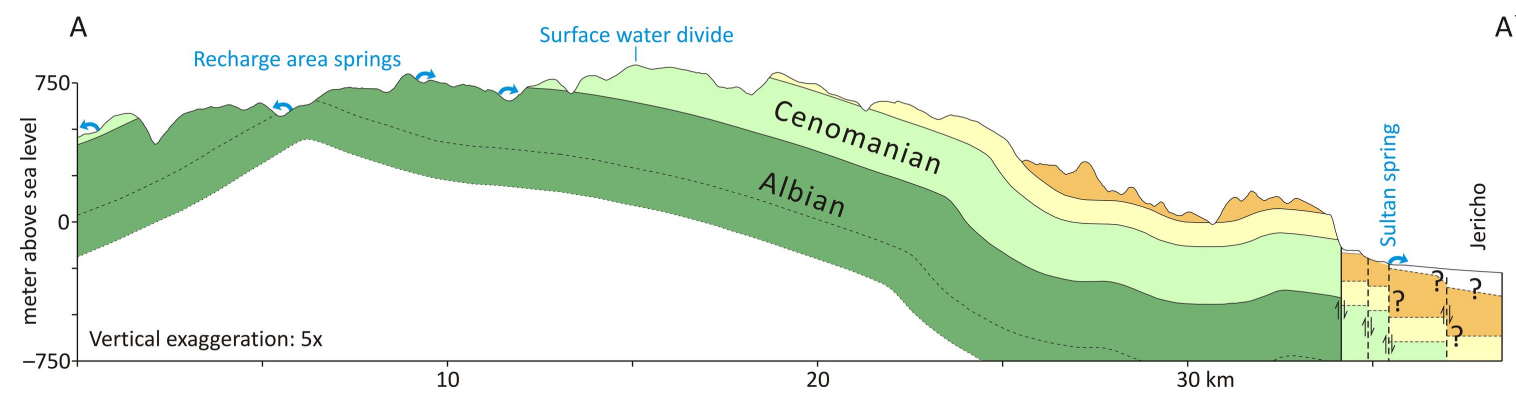

Fig. 3.2: Schematic cross-section through the study area. For location refer to Fig. 3.1. Land surface after Google Earth@ (http://www.google.de/intl/de/earth/index.html). 


\section{Class I: Springs in the western highland area (recharge area springs)}

The numerous springs in the western highland area are mainly contact springs. Their individual mean discharge is usually well below $1.01 \mathrm{~s}^{-1}$ (Nuseibeh and Nasser Eddin, 1995). The catchment areas display a maximum size of a few square kilometres (Weiss and Gvirtzman, 2007). Discharge is displaying high fluctuations according to the annual rainfall (Nuseibeh and Nasser Eddin, 1995; Palestinian Water Authority, 2000). Many springs of class 1 are located within outcrop areas of the geological strata that display properties of aquitards on a regional scale, i.e. the springs discharge perched groundwater horizons. This is especially pronounced in the basal layers of the Albian, the upper aquitard of the Albian, and the basal aquitard within the Cenomanian strata (Figs. 3.1-3.3).

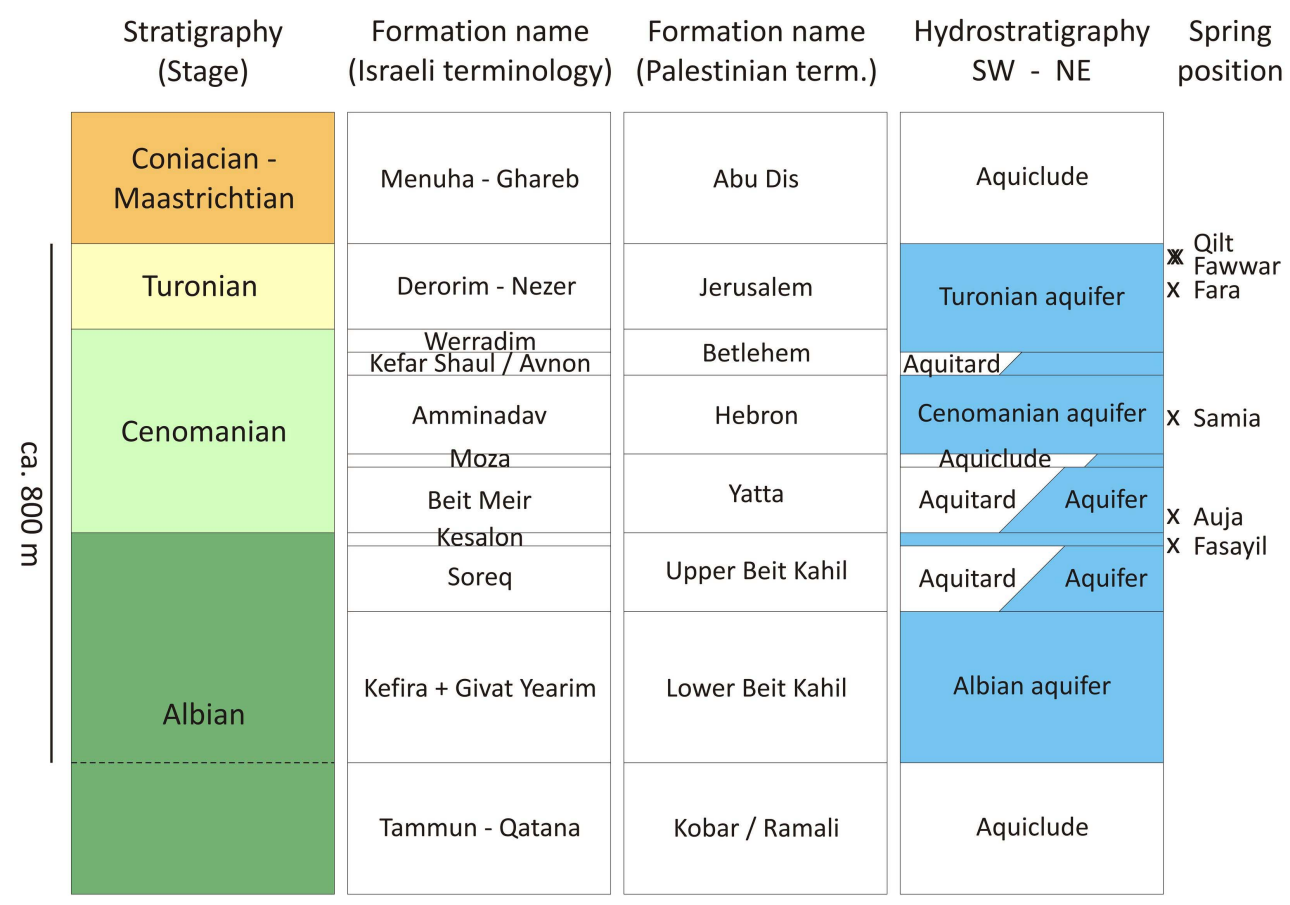

Fig. 3.3: Stratigraphic table of the Cretaceous formations in the study area. The hydrostratigraphy changes laterally throughout the study area. Diagram compiled after ANTEA (1998), Begin (1975), Rofe \& Raffety Consulting Engineers (1963, 1965), Shachnai (2000), and Wolfer (1998).

\section{Class 2: Springs in the eastern slopes and Jordan Valley}

In the slopes towards the Jordan Valley and in the valley itself, eight larger springs emerge (Fig. 3.1). They discharge groundwater from the upper sections of the carbonate aquifer system (Rosenthal and Kronfeld, 1982). The springs Sultan (also commonly named Elisha spring) and Duyuk display a very stable discharge rate $\left(Q_{\max } / Q_{\min } \sim 1.5\right)$ and they are the basis for the water supply of the oasis of Jericho. In contrast, the springs Fawwar and Auja display a highly variable discharge and were occasionally observed to dry up during autumn. The location and the size of the groundwater catchment areas are not known, which makes groundwater protection difficult. Isotope tracer data $\left({ }^{3} \mathrm{H},{ }^{14} \mathrm{C}\right)$ for the Wadi Qilt springs and Sultan spring were evaluated by Kroitoru (1987) and Lange (2012). The mean residence time of modern groundwater was estimated to be around 20 years for the springs (Lange, 2012). 


\subsubsection{Land use, water supply and wastewater disposal}

The dominant vegetation and land use types in the recharge area of the carbonate aquifer system are grassland/shrubland, often interspersed with bare rock outcrops and mostly used for grazing of goats and sheep. Areas of rain-fed agriculture, urban areas, and olive groves account for smaller portions of the land surface.

In the study area, drinking water is supplied from different sources and their respective proportions changed considerably during the last 100 years. Nowadays, the bulk amount of drinking water is imported from sources located outside the study area. It is a very variable mixture of water from Lake Tiberias (Sea of Galilee) (Fig. 3.1), the regional carbonate aquifer (Section 3.2.2), and to a lesser extent from a clastic sediment aquifer of the Mediterranean Sea coastal plain. Since 2007, considerable quantities are obtained from desalination plants located at the Mediterranean Sea shore. As the percentage of each source is frequently changing due to management decisions, the chloride concentration of the water is changing as well. A concentration range of $150-220 \mathrm{mg} \mathrm{l}^{-1}$ can be expected for the drinking water during the last few decades (Mekorot internal database).

In the larger cities of the area under investigation wastewater is usually collected by sewers, whereas in rural areas, the use of cesspits and septic tanks are the prevailing wastewater disposal methods. The input of wastewater into the underlying carbonate aquifer is assumed to take place by three main mechanisms: (1) from leakage of sewer networks, (2) from cesspits and leakage of septic tanks, and (3) from local wastewater disposal into the ephemeral valleys. In the ephemeral valleys, the wastewater usually infiltrates into the outcropping carbonate rocks after a short surface flow distance.

\subsection{Methods}

\subsection{Collection of the database}

For the collection of the data an extensive study of reported literature was conducted. Furthermore, to obtain recent data, spring discharge measurements and hydrochemical sampling were carried out.

\section{Atmospheric chloride deposition}

The main atmospheric source of chloride in the area is the Mediterranean Sea. The chloride concentration in precipitation displays a relatively strong inland decrease from the Mediterranean Sea shore eastward (Eriksson and Khunaksem, 1969). However, as this gradient diminishes inland, the concentration becomes relatively constant across the central mountain range of the study area (Marei et al., 2010). Reported data for the average chloride concentration in local rainfall are compiled in Table 3.2. An average chloride concentration of $9.4 \mathrm{mg} \mathrm{l}^{-1}$ for bulk precipitation was calculated from the three mean values. 
Table 3.2: Mean precipitation chloride concentration of the Jerusalem region.

\begin{tabular}{cccc}
\hline Monitoring period & Hydrological years sampled & ${\text { Mean } \mathrm{Cl}^{-} \text {conc. }\left(\mathrm{mg} \mathrm{l}^{-1}\right)}^{\text {Reference }}$ \\
\hline $\begin{array}{l}1960-1963 \\
1981-1984\end{array}$ & 3 & 9.7 & Yaalon and Ganor (1968) \\
$1988-1990$ & 5 & 9.2 & Herut et al. (2000) \\
$2001-2005$ & 4 & 9.3 & Marei et al. (2010) \\
\hline
\end{tabular}

\section{Chloride and nitrate concentration in spring water}

Groundwater hydrochemical data were compiled from four different studies/monitoring periods during the 20th century (Table 3.3). Between 1938 and 1946, selected springs were sampled by the Irrigation Service of the British Government of Palestine (Department of Land Settlement and Water Commissioner, 1947a, b, c; Blake and Goldschmidt, 1947). The bulk of data are available from regular sampling conducted by the West Bank Water Department. The results are reported in Palestinian Water Authority (2000). The samples up to 1997 were analysed at the laboratory of the Hydrological Service of Israel in Jerusalem (Executive Action Team, 2000). Chloride was measured on a semi-annual time step usually in spring and autumn during the years 1968-1998. Nitrate was sampled from autumn 1982 at the same time resolution.

Recent groundwater samples from the class 2 springs were obtained in the course of this study during the years 2011-2012. In addition to chloride concentration, selected samples were also analysed for nitrate, bromide, and iodide concentration. Chloride, nitrate, and bromide concentrations were analysed with standard ion chromatography. Iodide concentration was analysed photometrically (German norm method DIN 38405-33, 2001).

Table 3.3: Overview of the different spring water hydrochemistry monitoring periods for the study region.

\begin{tabular}{cccl}
\hline Monitoring period & Sample $n \mathrm{Cl}^{-}$ & Sample $n \mathrm{NO}_{3}^{-}$ & Reference \\
\hline $1938-1946$ & 17 & - & $\begin{array}{l}\text { Department of Land Settlement and Water } \\
\text { Commissioner }(1947 \mathrm{a}, \mathrm{b}, \mathrm{c}) ; \\
\text { Blake and Goldschmidt }(1947)\end{array}$ \\
$1951-1954$ & 6 & 1 & Wilson and Wozab (1954) \\
$1961-1963$ & 40 & 20 & Rofe \& Raffety Consulting Engineers $(1963,1965)$ \\
$1968-1998$ & ca. 2200 & ca. 900 & Palestinian Water Authority $(2000)$ \\
$2011-2012$ & 18 & 12 & This study \\
\hline
\end{tabular}

\section{Chloride concentration of local wastewater}

The chloride concentration of wastewater from the Jerusalem-Ramallah region is assumed to display relatively similar chloride concentrations to that of the Tel Aviv region, because the drinking water sources for both regions are similar, however, their proportion is different. Between 1977 and 2009 the average concentration of treated wastewater of the large Shafdan wastewater treatment plant near Tel Aviv was ca. $280 \mathrm{mg} \mathrm{l}^{-1}$ (Table 3.4). Abu Sharkh (2008) reported average chloride concentrations of wastewater from three different rural communities in the West Bank (Table 3.4, average $340 \mathrm{mg} \mathrm{l}^{-1}$ ). Based on these observations a mean wastewater chloride concentration of $300 \mathrm{mg} \mathrm{l}^{-1}$ was applied for this study. 
Table 3.4: Mean chloride concentration of wastewater treatment plant (WWTP) effluents measured at different sites of the West Bank and Israel.

\begin{tabular}{|c|c|c|c|c|c|}
\hline $\begin{array}{l}\text { Monitoring } \\
\text { period }\end{array}$ & Sample type & $\begin{array}{l}\text { Range } \mathrm{Cl}^{-} \text {conc. } \\
\qquad\left(\mathrm{mg} \mathrm{l}^{-1}\right)\end{array}$ & $\begin{array}{l}\text { Mean } \mathrm{Cl}^{-} \text {conc. } \\
\qquad\left(\mathrm{mg} \mathrm{l}^{-1}\right)\end{array}$ & $\begin{array}{l}\text { Sampling } \\
\text { site }\end{array}$ & Reference \\
\hline 1977-2009 & $\begin{array}{l}\text { Annual } \\
\text { average }\end{array}$ & $180-360$ & 280 & $\begin{array}{l}\text { Shafdan } \\
\text { WWTP }\end{array}$ & $\begin{array}{l}\text { Vengosh and Keren (1996); } \\
\text { Gasser et al. (2010) }\end{array}$ \\
\hline 2006-2007 & $\begin{array}{l}\text { WWTP } \\
\text { average }\end{array}$ & $240,380,410$ & 340 & $\begin{array}{l}\text { Rural West } \\
\text { Bank }\end{array}$ & Abu Sharkh (2008) \\
\hline
\end{tabular}

\section{Spring discharge measurements and precipitation time series}

Precipitation data for Jerusalem before 1951 were adapted from Rosenan (1955) and data after 1951 were obtained from the European Climate Assessment and Dataset (http://eca.knmi.nl; Klein Tank et al., 2002). Monthly discharge data for Sultan spring during the hydrological years of 1933-1946 originate from measurements by a fixed sharp-crested weir and are reported in Department of Land Settlement and Water Commissioner (1947a, b, c). During the hydrological years of 1968-2000, monthly spring discharge measurements were conducted for the class 2 springs by the West Bank Water Department (Palestinian Water Authority database). During the period 2009-2012, occasional discharge measurements with the salt dilution method were conducted by the authors.

\subsubsection{Identification of anthropogenically influenced springs}

For the identification of anthropogenically influenced springs, the compiled time series of chloride and nitrate were used. Two criteria were employed, namely (1) the mean nitrate concentration of spring water and (2) the occurrence of trends in the time series. The analysis was performed separately for the class 1 and 2 springs.

The hydrochemical time series for the class 1 springs usually consisted of about 50 individual chloride samples and about 20 nitrate samples during the period of 1968-1998. A groundwater nitrate concentration of $>10 \mathrm{mg} \mathrm{l}^{-1}$ is often considered indicative for an anthropogenic influence (e.g. Wendland et al., 2006). For this study, the threshold value (exclusion criterion) was not fixed a priori, but also the occurrence of chloride concentration trends was considered. The springs which are regarded as anthropogenically influenced were excluded from recharge calculations, because their chloride concentration is expected to be in excess of the natural level. For the uninfluenced springs, the data were checked for obvious outliers from possible measurement errors and the average chloride concentrations were calculated.

The available chloride concentration time series for the class 2 springs largely cover time periods between 65 and 75 years. However, the bulk of data is also available for the period of 1968-1998. A possible trend was investigated by (1) a linear regression analysis, providing regression line slope and intercept and (2) the Mann-Kendall trend test (Helsel et al., 2006), providing a probability value ( $p$-value). In this study, $p$-values below 0.05 were considered to display a significant trend. 


\subsubsection{Assessing the natural background concentration of chloride in groundwater}

Natural geogenic chloride sources should be negligible in carbonate rock aquifer systems which do not contain evaporitic minerals like halite. In those systems, the natural groundwater chloride concentration is solely a function of the chloride concentration in local precipitation and its concentration increase by evapotranspiration. However, nowadays a number of anthropogenic chloride sources may contribute to the natural chloride concentration (Panno et al., 2006). For example, in temperate and polar climate regions, large amounts of chloride are introduced to the environment by road de-icing salt (Godwin et al., 2003; Kelly et al., 2010).

For Sultan spring, a short time series $(n=8)$ is available between January 1938 and September 1940, permitting statistical analysis. The mean value is considered as the background value, assuming that anthropogenic contributions were still absent or insignificant during this period. Since the other springs are characterised by only limited historical data records, two other background estimation techniques were applied. First, the $y$-value of the linear regression line (time series up to 1998) for January 1945 was calculated. This date is still located within the measured time series for most class 2 springs and is considered as the approximate onset of anthropogenic influence in the spring water. Second, from the historical/early post-historical data up to 1955, the minimum measured concentrations were determined.

\subsubsection{Estimating long-term mean groundwater recharge}

Since estimates of groundwater recharge sometimes involve large uncertainties, the comparison of the results of different estimation techniques is advisable (Scanlon et al., 2002; Healy, 2010). In this study, the chloride mass balance and an empirical approach are applied.

\section{Chloride mass balance}

The chloride mass balance approach requires that chloride concentration in the groundwater originates from precipitation only and that other geogenic or anthropogenic sources are negligible. Chloride enrichment in the soil zone is directly proportional to evapotranspiration. Percolation of water from the soil zone to the groundwater table results in groundwater recharge. Since this study used groundwater chloride concentrations for calculation, estimates of actual recharge are obtained, in contrast to estimates of percolation (=potential recharge), e.g. from unsaturated zone approaches (Scanlon et al., 2002). Provided stationary conditions or sufficient long time series of chloride concentration in precipitation $\left(\mathrm{Cl}^{-} \mathrm{p}\right)$ and groundwater $\left(\mathrm{Cl}^{-}{ }_{\mathrm{gw}}\right)$, from which mean values can be obtained, the long term average recharge fraction (RF) of precipitation can be calculated with the following equation:

$$
R F=\frac{\mathrm{Cl}_{\mathrm{p}}^{-}}{\mathrm{Cl}_{\mathrm{gw}}^{-}}
$$

Precipitation can be sampled locally with rainfall collectors. Groundwater is usually sampled at springs or from groundwater wells. The analysis of spring water provides an integral catchment- 
based concentration value, because it can be usually assumed that groundwater flow in a spring catchment converges to a single outlet. However, in the case of complex karstified aquifer systems this assumption is not necessary valid (e.g. Mudarra et al., 2012).

\section{Empirical recharge estimation}

The regional groundwater recharge rate $\left(R\right.$ in $\left.\mathrm{mm} \mathrm{a}^{-1}\right)$ for the carbonate aquifer system was estimated by Goldschmidt (1959) based on water budget calculations. Guttman and Zuckerman (1995), and Guttman (2000) combined water budget calculations with transient numerical groundwater modelling. Empirical relationships between annual precipitation depth $(P$ in $\mathrm{mm}$ $\left.\mathrm{a}^{-1}\right)$ and estimated groundwater recharge were established. For the Eastern Aquifer System, Guttman and Zuckerman (1995) proposed Eqs. (3.2)-(3.4), which are a refinement of the equation of Goldschmidt (1959).

$$
\begin{array}{ll}
R=0.15 * P & \text { yearly precipitation depth }<300 \mathrm{~mm} \\
R=0.534 *(P-216) & \text { yearly precipitation depth } 300-650 \mathrm{~mm} \\
R=0.80 *(P-360) & \text { yearly precipitation depth }>650 \mathrm{~mm}
\end{array}
$$

\subsubsection{Discrimination of anthropogenic and geogenic sources of chloride in groundwater by their $\mathrm{Cl}^{-} / \mathrm{Br}^{-}$and $\mathrm{Cl}^{-} / l^{-}$ratios}

The ratio of chloride and bromide (here denoted as the mass ratio), may be used to distinguish different geogenic and anthropogenic influences on groundwater (Davis et al., 1998; Alcalá and Custodio, 2008; Katz et al., 2011). The $\mathrm{Cl}^{-} / \mathrm{Br}^{-}$ratio in seawater is about 290 (Morris and Riley, 1966). Precipitation displays a ratio close to seawater in coastal areas (Alcalá and Custodio, 2008). Saline groundwater/basin brines display a large spectrum of $\mathrm{Cl}^{-} / \mathrm{Br}^{-}$ratios (Davis et al., 1998). Brines are present in parts of the Cretaceous aquifers in the Lower Jordan Valley (e.g. Guttman, 2000). Lower sections of the aquifer system are more affected, e.g. the regional Albian aquifer (Marie and Vengosh, 2001). The brines of the Jericho region are believed to be remnants of the precursors of the Dead Sea, which at times had a much higher water level than the present Dead Sea (Möller et al., 2007). The brackish or saline groundwater in the lower aquifer system displays a well documented $\mathrm{Cl}^{-} / \mathrm{Br}^{-}$ratio of about 40-80 (Guttman, 2000; Marie and Vengosh, 2001; Möller et al., 2007), close to the $\mathrm{Cl}^{-} / \mathrm{Br}^{-}$ratio of the Dead Sea of ca. 40 (Möller et al., 2007). In contrast, the $\mathrm{Cl}^{-} / \mathrm{Br}^{-}$ratio of sewage is often higher than that of the meteoric water from which it originates, due to the intensive domestic and industrial use of $\mathrm{NaCl}$-salt (halite), which displays a high $\mathrm{Cl}^{-} / \mathrm{Br}^{-}$ratio. Davis et al. (1998) state a ratio of 300-600 for sewage.

The abundance of iodide in the environment and $\mathrm{Cl}^{-} / \mathrm{I}^{-}$ratios are not as well investigated. Panno et al. (2006) derive high $\mathrm{Cl}^{-} / \mathrm{I}^{-}$mass ratios of about 13000 for septic effluent. In their study, other anthropogenic and natural end members show much lower median ratios, e.g. uninfluenced groundwater 660, landfill leachate 1000, and animal waste 3600 . The authors regard the low ratio for landfill leachate in combination with chloride concentration to constitute a convenient indicator parameter. 


\subsubsection{Mixing model for the quantification of anthropogenic and geogenic chloride sources}

The addition of wastewater or brine to groundwater can be calculated by a classical chemical mass balance technique (Pinder and Jones, 1969), i.e. a mixing model between end-members of significantly different solute concentration. Prerequisites are stable concentrations of the end members and complete mixing. For example, the fraction of groundwater originating from wastewater infiltration $\left(F_{\mathrm{ww}}\right)$ can be calculated according to equation 3.5, with $\mathrm{Cl}^{-}$nb as the natural background concentration of chloride in groundwater, $\mathrm{Cl}^{-}$gw the measured concentration of chloride in groundwater, and $\mathrm{Cl}^{-}{ }_{\text {ww }}$ the concentration of chloride in wastewater. All concentrations are given in units of $\mathrm{mg} \mathrm{l}^{-1}$.

$$
F_{w w}=\frac{\left(\mathrm{Cl}_{\mathrm{gw}}^{-}-\mathrm{Cl}_{\mathrm{nb}}^{-}\right)}{\left(\mathrm{Cl}_{\mathrm{ww}}^{-}-\mathrm{Cl}_{\mathrm{nb}}^{-}\right)}
$$

For the graphical analysis of a potential brine admixture, mixing lines of the $\mathrm{Cl}^{-} / \mathrm{Br}^{-}$ratio between end-members were calculated. For this purpose, the mixing calculations of chloride and bromide were performed separately in steps of e.g. $1 \%$ admixture. Subsequently the $\mathrm{Cl}^{-} / \mathrm{Br}^{-}$ratio was calculated for each step.

\subsection{Results and discussion}

\subsection{Identification of anthropogenic influenced class I springs}

The mean nitrate concentrations of the class 1 springs for 1982-1998 can be divided into two groups. One group displayed concentrations of 2-11 $\mathrm{mg} \mathrm{l}^{-1}$ (median: $5 \mathrm{mg} \mathrm{l}^{-1}, n=25$ ), the other group concentrations of 15-190 $\mathrm{mg} \mathrm{l}^{-1}$ (median: $43 \mathrm{mg} \mathrm{l}^{-1}, n=11$ ) (Appendix A). The springs of the low nitrate concentration group in general displayed stable chloride concentrations. In contrast, the springs of the high nitrate concentration group displayed high and fluctuating chloride concentrations, often with an upward or downward trend. These springs are generally located in or near populated areas. For example, the Gihon (Um Al Daraj) spring located near the old city of Jerusalem displayed a mean nitrate concentration of $190 \mathrm{mg} \mathrm{l}^{-1}$ and a mean chloride concentration of $230 \mathrm{mg} \mathrm{l}^{-1}$, with a downward trend. Amiel et al. (2010) obtained comparatively high values during the hydrological year 2004/2005 and also faecal coliform bacteria counts up to 12000 per $100 \mathrm{ml}$ were measured. In accordance with Rofe \& Raffety Consulting Engineers (1963, 1965), infiltrating wastewater is strongly expected to be the source of the elevated chloride concentration for the class 1 springs.

\subsubsection{Potential geogenic and anthropogenic chloride sources for class $\mathbf{2}$ springs}

Most springs of class 2 displayed an increasing chloride and nitrate concentration (Figs. 3.4 and 3.5). The mean nitrate concentrations (1982-1998) ranged between 11 and $21 \mathrm{mg} \mathrm{l}^{-1}$ (Appendix A). Only Auja spring fulfils the nitrate concentration exclusion criterion $\left(\leq 11 \mathrm{mg} \mathrm{l}^{-1}\right)$, established for 
the class 1 springs. Since class 2 springs are located far away from population centres, sometimes at low topographic elevations, other geogenic and antropogenic chloride sources have to be taken into account. Natural impacts include, for example, a decrease in groundwater recharge and an admixture of saline groundwater (basin brines). Potential anthropogenic chloride sources are wastewater infiltration, solid waste disposal (landfill leachate), agricultural practices (fertilisers), and animal husbandry (animal waste/manure), as well as the application of road de-icing salt.
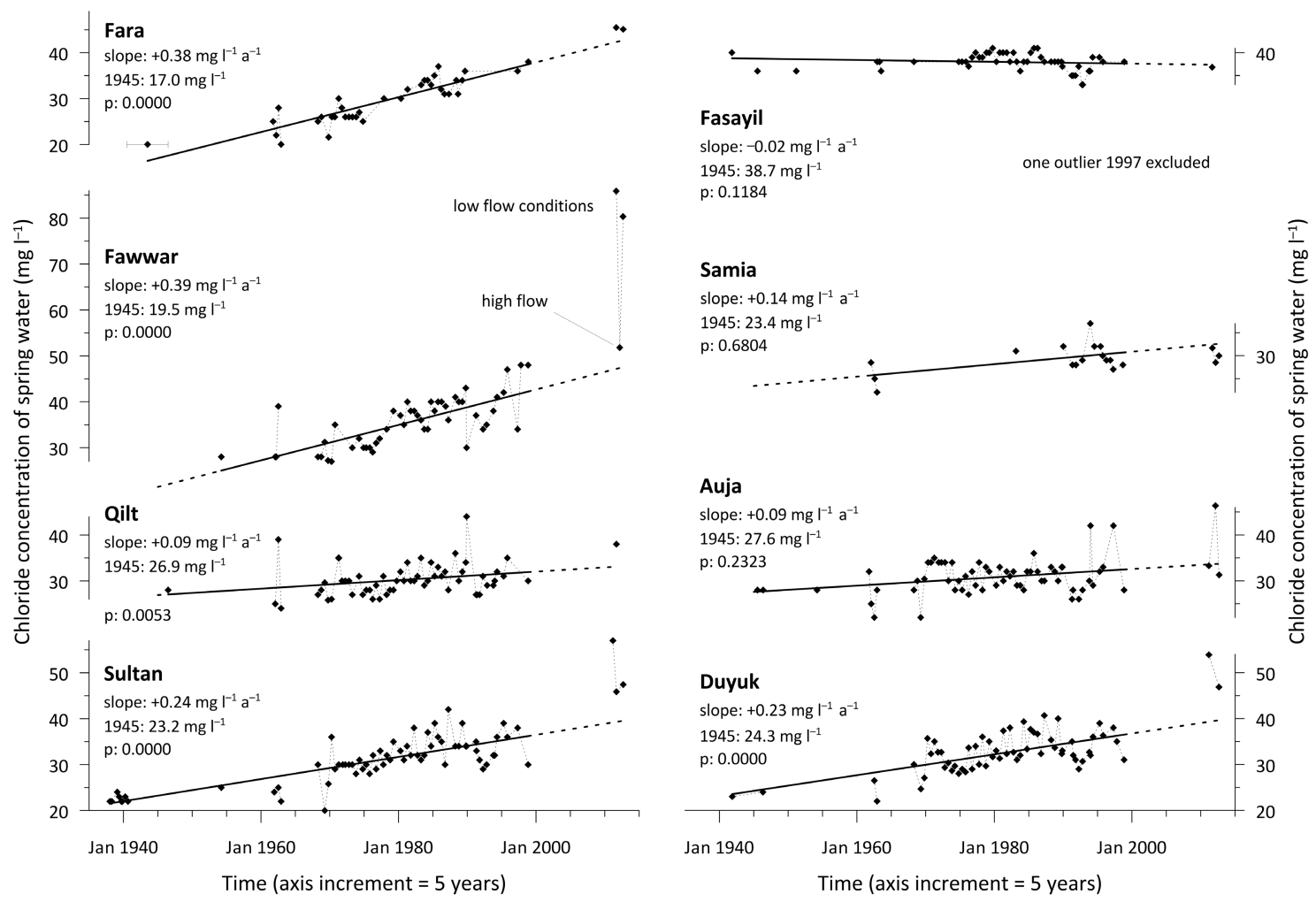

Fig. 3.4: Chloride concentration time series of the eight class 2 springs. Statistical parameters for the time series up to 1998 are given: (1) linear regression line with slope and $y$-value for January 1945, (2) $p$-value of the MannKendall trend test. Note that the short data range for the Samia spring renders the fit susceptible to outliers.

A decrease in mean groundwater recharge fraction can lead to an increase in the chloride concentration in groundwater, since the chloride concentration of precipitation is accordingly more concentrated by evapotranspiration. Annual precipitation depth and consequently groundwater recharge is highly variable in the study area. Furthermore, there is often a systematic sequence of several wet years and several dry years (Fig. 3.6). After some prominent rainfall years or a sequence of years with higher-than-average precipitation, a certain decrease in groundwater chloride concentration can be recognised (Fig. 3.4, e.g. after the exceptional pluvial winter season 1991/1992). However, averaged over long periods, the mean groundwater recharge fraction estimated from precipitation data displays a relatively low variability (Fig. 3.6). The calculated mean decadal recharge fraction of precipitation was 29\% during the 1920s, 1930s, and 1950s and $35 \%$ during the 1970s and 1990s, based on Jerusalem precipitation data (Fig. 3.6). 


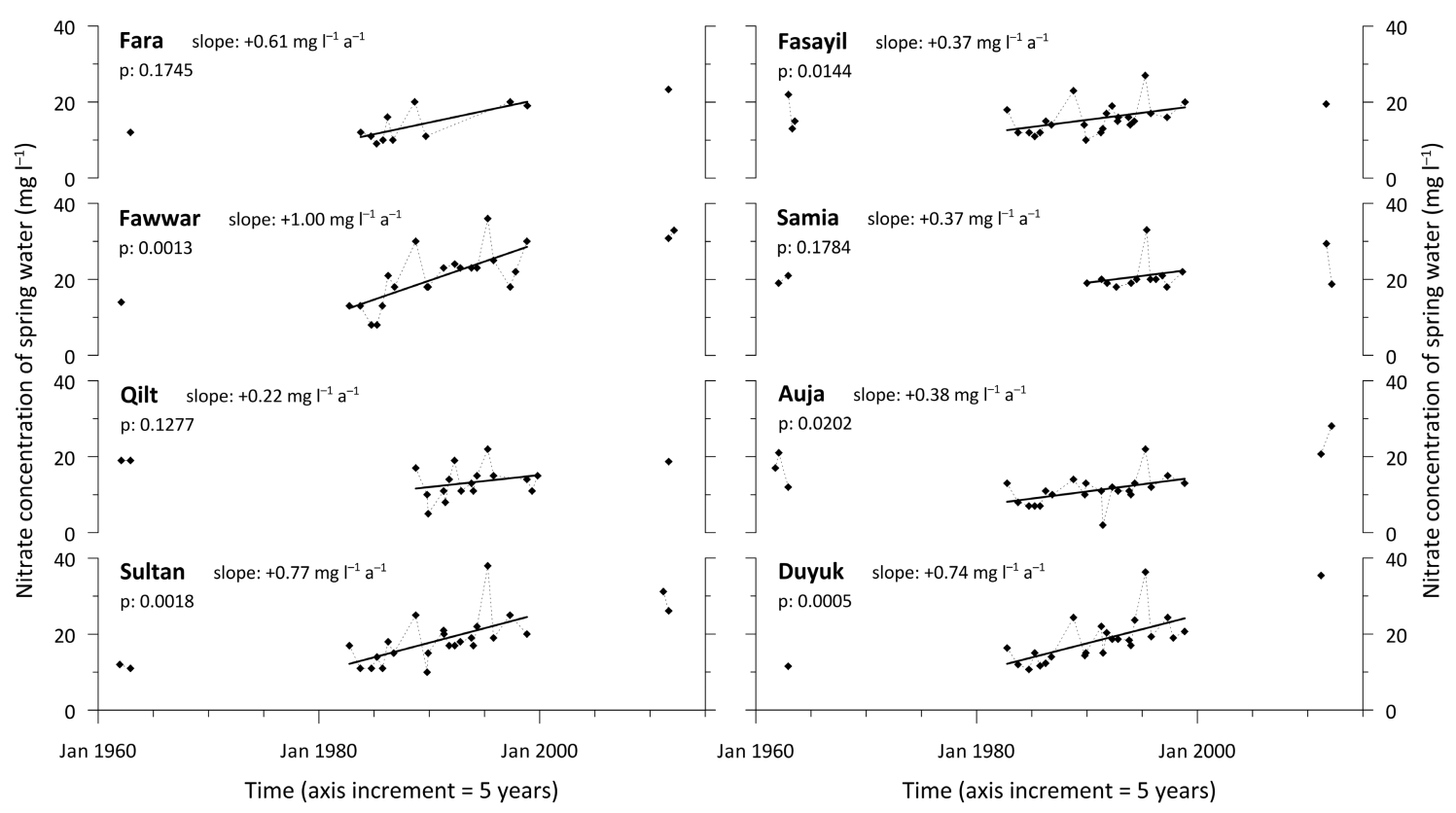

Fig. 3.5: Nitrate concentration time series of the class 2 springs along with the linear regression line and its slope for the core time series. Furthermore, the $p$-value of the Mann-Kendall trend test is given.

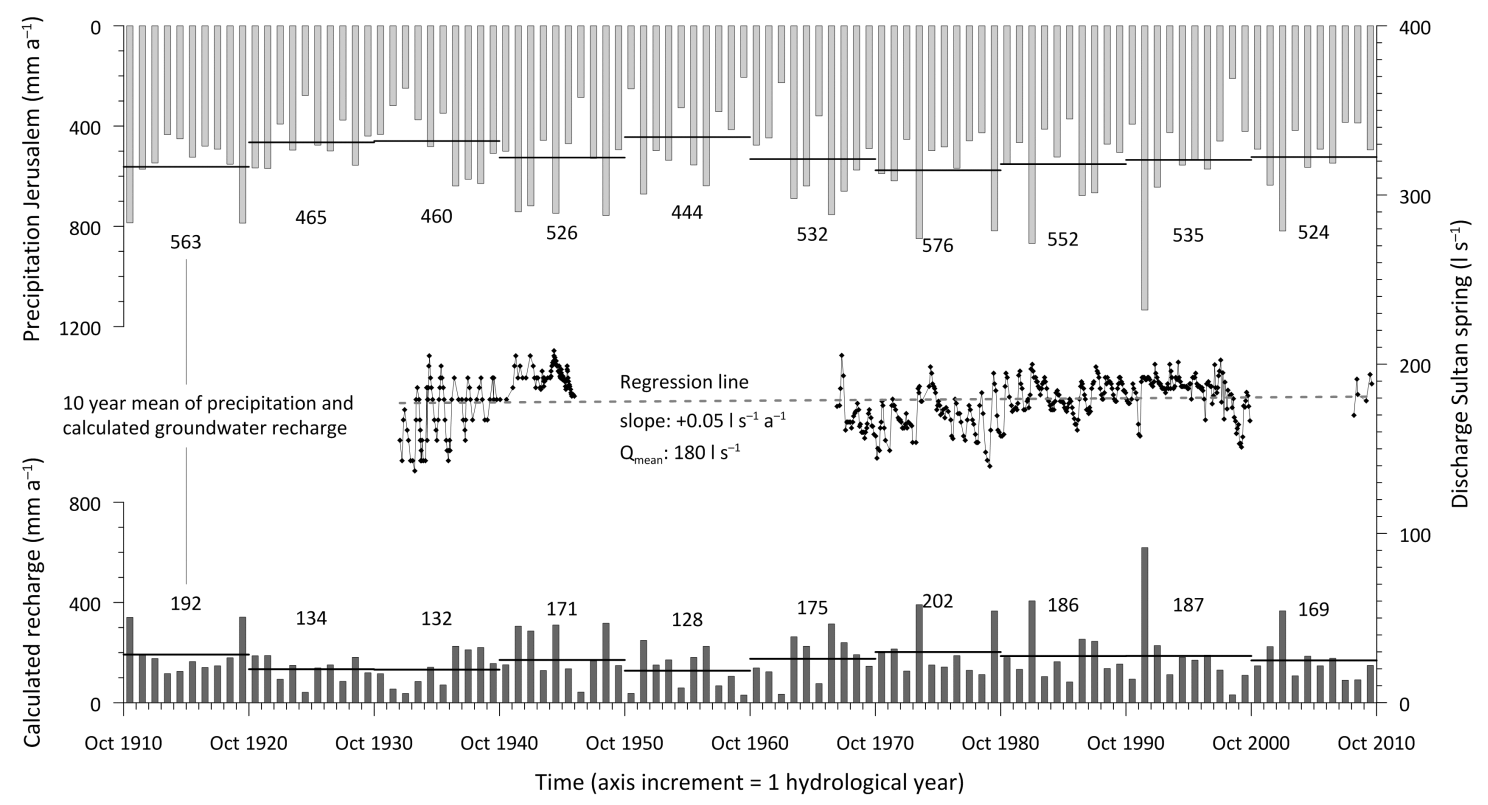

Fig. 3.6: Annual precipitation depths for Jerusalem for 100 hydrological years as well as discharge data for Sultan spring. Groundwater recharge was calculated from the precipitation values with the Guttman and Zuckerman equation (Eqs. (3.2)-(3.4)). For the 100 year record, mean precipitation is $522 \mathrm{~mm} \mathrm{a}^{-1}$, mean calculated groundwater recharge is $170 \mathrm{~mm} \mathrm{a}^{-1}$, i.e., $33 \%$.

Most springs of class 2 discharge from upper aquifer layers and are located in topographically elevated positions, from where no brines have been reported. However, the springs Sultan, Duyuk, and Fasayil are relatively deep-seated discharge points (compare Fig. 3.2) and a potential admixture of highly mineralised water cannot be excluded. All analysed samples from the springs displayed a $\mathrm{Cl}^{-} / \mathrm{Br}^{-}$mass ratio of about $260-300$ (Table 3.6), which is close to the ratio in seawater of ca. 290 (Morris and Riley, 1966). The samples plot on a mixing line with a 
hypothetical sewage of moderate $\mathrm{Cl}^{-} / \mathrm{Br}^{-}$mass ratio (Fig. 3.7). Therefore, a contribution of brines to the steadily rising chloride concentrations can be precluded. The moderate ratio of the hypothetical sewage is presumably a result of the high proportion of water from Lake Tiberias in drinking water, which displays a low $\mathrm{Cl}^{-} / \mathrm{Br}^{-}$ratio. However, as the composition of the domestic water changes, the resulting sewage will display a variable $\mathrm{Cl}^{-} / \mathrm{Br}^{-}$ratio as well.

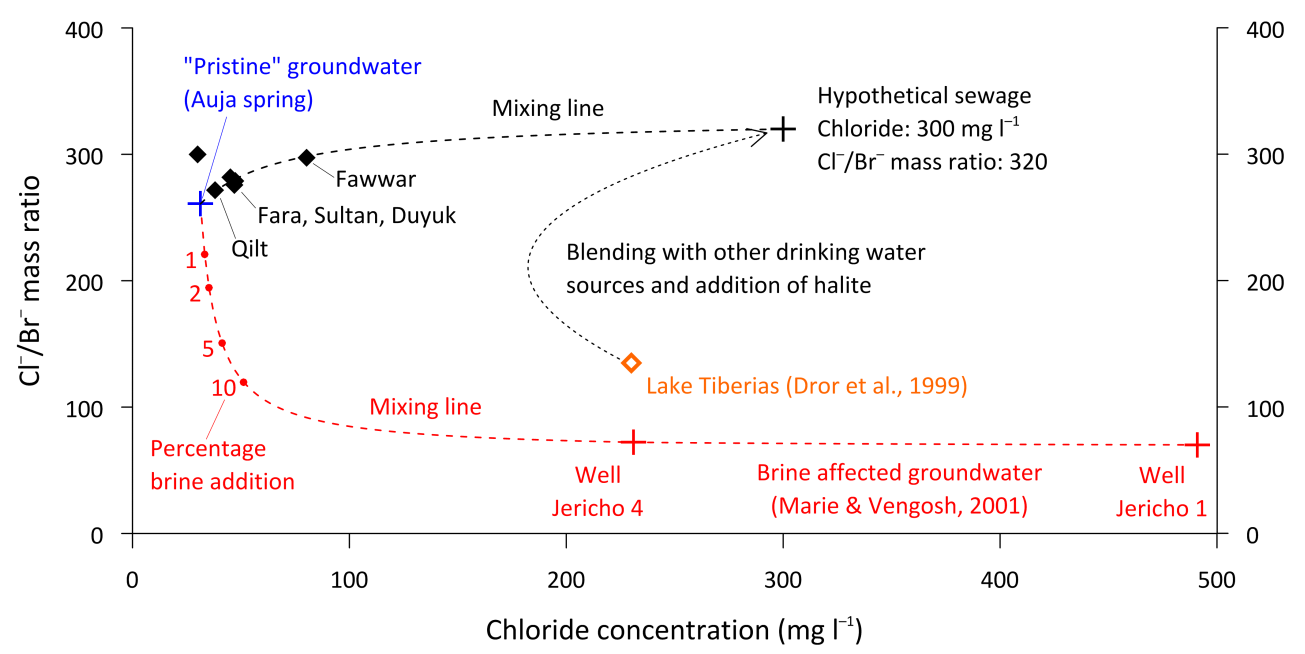

Fig. 3.7: Chloride vs. $\mathrm{Cl}^{-} / \mathrm{Br}^{-}$mass ratio plot of spring water and potential end members of natural or anthropogenic origin together with binary mixing lines.

Since drinking water shows a chloride concentration of ca. $200 \mathrm{mg} \mathrm{l}^{-1}$ throughout large parts of the study area (Section 3.2.3), not only wastewater infiltration but also a leakage of supply networks will introduce additional chloride mass to the groundwater environment. The loss rates are typically between $5 \%$ and $10 \%$ for the public water supply networks in the study area, but can reach up to $40 \%$ for some old network sections. Wastewater production is typically about $70 \%$ of consumed drinking water. During the past decades, a large increase in the total amount of drinking water consumption and resulting sewage can be assumed, because of the high population growth since the 1920s in combination with a considerable increase in living standards, implying higher water consumption per capita. Census data and estimates are documented in e.g. McCarthy (1990), Bachi (1974), Palestinian Central Bureau of Statistics (2009), and Brinkhoff (2013).

An infiltration of landfill leachate can increase the groundwater chloride concentration, because its chloride concentration can reach up to several thousand $\mathrm{mg} \mathrm{l}^{-1}$ (Albaiges et al., 1986; Vadillo et al., 1999; Kjeldsen et al., 2002). Considering the mass of solid municipal waste formation in the study area (e.g. Al-Khatib et al., 2007) and its expected chloride concentration, it can be concluded that the infiltrating leachate chloride mass will be small compared to the chloride mass derived from wastewater discharge. Also, the chloride/iodide mass ratio can assist in the discrimination of a landfill leachate contribution, as it displays a low $\mathrm{Cl}^{-} / \mathrm{I}^{-}$ratio (Panno et al., 2006). The sample of Auja spring from September 2012 (Table 3.6) is assumed to be largely uninfluenced by anthropogenic chloride sources. $\mathrm{A} \mathrm{Cl}^{-} / \mathrm{I}^{-}$mass ratio of 3500 was determined. In contrast, the ratios for the other springs assumed to be affected, ranged in the order of 5000. Fawwar spring displayed the highest value. Because of the high $\mathrm{Cl}^{-} / \mathrm{I}^{-}$mass ratios in the samples which display high chloride concentrations, landfill leachate is unlikely to constitute the main anthropogenic chloride source. Agricultural practices and animal husbandry are conducted in the rural parts of 
the study area. Fertilizer use is low and predominantly phosphate and nitrogen fertilizers are applied (Abu-Alrub et al., 2004), therefore the application of fertilizers containing substantial amounts of $\mathrm{Cl}^{-}$(e.g. potassium chloride) is likely to be negligible. Manure is expected to constitute a source of chloride, however, the contribution is also estimated to be small. Road salt is not applied in the study area, because sub-zero temperatures are observed infrequently.

\subsubsection{Additional wastewater indicators for the class 2 springs}

Khayat et al. (2006) measured the stable isotopes of nitrogen and oxygen of nitrate samples from the Sultan and Duyuk springs. They obtained values of ca. $10 \%$ or $\delta^{15} \mathrm{~N}^{-\mathrm{NO}^{3-}}$ and $3-4 \%$ o for $\delta^{18} \mathrm{O}_{-} \mathrm{NO}^{3-}$, which clearly direct to a nitrate source from sewage or manure (Clark and Fritz, 1997; Katz et al., 2009). Contamination of the Fawwar spring by wastewater was reported by Wolfer (1998). The author documented a visible breakthrough of wastewater at the spring in November 1998. The discharging water was reported to be turbid and lead to the death of fish in the spring pool. The chloride concentration was reported to be $103 \mathrm{mg} \mathrm{l}^{-1}$ and also high counts of faecal coliform bacteria were measured. The presence of faecal coliform bacteria was confirmed by Daghrah (2010) for the springs Fawwar and Qilt. Stable isotopes in nitrate were also analysed for the wells tapping the lower regional Albian aquifer (Schilman et al., 2004). The results show a wastewater origin of the nitrate. In contrast to the springs, faecal coliform bacteria were only found in a few of the deep wells, believed to be influenced by fast flow pathways (Hasan and Guttman, 2012). The Albian aquifer system displays a considerably longer residence time compared to the spring flow system (Kroitoru, 1987). Therefore, the microbiological contamination is attenuated.

\subsubsection{Hydrogeological implications of the chloride concentration trends}

With subsurface catchments being unknown, the source of the wastewater observed in spring water is not easily traced back. Therefore, only a very coarse geographic differentiation can be made. The springs located in the less populated northern part of the study area (Fasayil, Samia, and Auja) show no distinctive trend or only a moderate increase. In contrast, the springs Fara, Fawwar, Sultan, and Duyuk, located close to the population centres in the southern half of the study area, display a strongly rising trend and high values of chloride in the last few years (Fig. 3.4; Table 3.6). Surprisingly, the increase for Qilt spring is only moderate, indicating a separate recharge area, influenced by wastewater infiltration to a lesser extent.

Based on similarities in trend and concentration, a connection of springs to common karst conduit systems and accordingly groundwater catchments can be postulated, especially for the Sultan and Duyuk springs. Similarities in mean chloride and nitrate concentration and chloride concentration trend are encountered for the springs Auja and Qilt. As the springs are located more than $13 \mathrm{~km}$ apart and the spring outlets are seated in different hydrostratigraphic units (Fig. 3.3), a common recharge area is highly improbable. 


\subsubsection{Estimation of natural background chloride concentration}

For the 25 anthropogenically uninfluenced springs of class 1 and Fasayil spring of class 2, the mean chloride concentration is expected to reflect the natural conditions (sensu "spatial background value", Kelly and Panno, 2008).

For most class 2 springs the natural background chloride concentrations were estimated by the analysis of historical (in this study up to 1946) and post-historical data. The determination procedure was adapted to the variable availability of early monitoring data and three different types of the method "historical data" were defined and compared. For Sultan spring, eight historical samples were available. The mean chloride concentration was $22.5 \mathrm{mg} \mathrm{l}^{-1}$ (standard deviation $=0.7 \mathrm{mg} \mathrm{l}^{-1}$ ) without a trend. This approach was regarded in this study as the method "historical data sensu stricto (HDss)". Mendizabal et al. (2012) considered a minimum of six historical samples for trend analysis. For all other springs, only few historical data were available. The background values were derived from a "trend analysis (TA)", i.e. the linear regression line was used to determine a probable background concentration representative for pre-impact times. Since the onset of recognisable anthropogenic influence can be expected to be variable for the individual catchments and springs, with the increase in concentration also being a function of the mean residence time in the aquifer, the selection of an appropriate reference date is not straightforward. However, for the springs Qilt and Auja, displaying a moderate upward trend, the $y$-value of the regression line 1945 agrees well with chloride concentrations measured at that time. This method is regarded as "trend analysis confirmed by historical data (TAconfirmed)" and values are regarded as reliable. Due to the large slope of the regression line for the springs Fara and Fawwar (Fig. 3.4), the selection of the reference date (i.e. January 1945) has a considerable influence on the calculated background value and the trend analysis yields comparatively low values. Fara spring displays the highest mean residence time of the Wadi Qilt springs (Kroitoru, 1987; Lange, 2012) and also displays a low standard deviation of chloride concentration (Table 3.5). Therefore, it is expected that the anthropogenic influence is well mixing with the bulk aquifer water and hence considerable anthropogenic influences are observed in spring water concentrations with an important time lag. For those springs, the lowest observed historical chloride concentration values were regarded as natural background concentration (method "minimum historical concentration (MHC)"). A similar method was used by Mendizabal et al. (2012) for samples from porous aquifers displaying an upward trend in the historical data already. However, in karstified aquifers caution must be paid, that the minimum values are not representing "accidental" low values due to breakthrough events of freshly recharged water following large rainstorms (or of course simply measurement errors). The results from this method are prone to error and regarded as an estimate. For Samia spring, the database is insufficient to derive a reliable background value. The relatively low concentration values of the recent samples (Table 3.6 and Fig. 3.4) suggest that the spring is not heavily influenced and that the background concentration calculated from the mean is likely to be closer to the true value. This value is likewise regarded as an estimate. The mean chloride concentration range for the uninfluenced class 1 springs (21-38 $\mathrm{mg} \mathrm{l}^{-1}$ ) matches the calculated/estimated background values for the class 2 springs $\left(20-38 \mathrm{mg} \mathrm{l}^{-1}\right)$. 
Table 3.5: Calculated background chloride concentration and mean groundwater recharge fraction for the class 2 springs. Different calculation methods (Historical data sensu stricto (HDss) = mean value, trend analysis (TA), ditto confirmed by historical data (TAconfirmed), and minimum historical concentration (MHC)) are indicated. Values in bold are considered reliable, values in brackets are considered to be less likely than the values without.

\begin{tabular}{|c|c|c|c|c|}
\hline Spring & $\begin{array}{l}\text { Background } \\
\text { determination method }\end{array}$ & $\begin{array}{l}\text { Background } \mathrm{Cl}^{-} \\
\text {concentration } \\
\left(\mathrm{mg} \mathrm{l}^{-1}\right)\end{array}$ & $\begin{array}{l}\text { Mean recharge rate } \\
\text { (\% of precipitation) }\end{array}$ & $\begin{array}{c}\mathrm{Cl}^{-} \text {-standard deviation } \\
\text { (trend corrected) } \\
\left(\mathrm{mg} \mathrm{l}^{-1}\right)\end{array}$ \\
\hline \multirow[t]{2}{*}{ Fara } & TA (1945) & $(17.0)$ & (55) & 2.2 \\
\hline & $\mathrm{MHC}$ & 20.0 & 47 & \\
\hline \multirow[t]{2}{*}{ Fawwar } & TA (1945) & $(19.5)$ & $(48)$ & 3.7 \\
\hline & $\mathrm{MHC}$ & 28.0 & 34 & \\
\hline Qilt & TAconfirmed (1945) & 26.9 & 35 & 3.4 \\
\hline \multirow[t]{2}{*}{ Sultan } & TAconfirmed (1945) & $(23.2)$ & $(41)$ & 3.0 \\
\hline & HDss (mean 1938-1940) & 22.5 & 42 & \\
\hline \multirow[t]{2}{*}{ Duyuk } & TAconfirmed (1945) & $(24.3)$ & (39) & 3.2 \\
\hline & MHC & 23.0 & 41 & \\
\hline Auja & TAconfirmed (1945) & 27.6 & 34 & 3.4 \\
\hline \multirow[t]{2}{*}{ Samia } & TA (1945) & $(23.4)$ & $(40)$ & 2.8 \\
\hline & mean 1962-1998 & 29.2 & 32 & \\
\hline \multirow[t]{2}{*}{ Fasayil } & TA (1945) & 38.7 & 24 & 1.9 \\
\hline & mean 1941-1998 & 37.9 & 25 & \\
\hline
\end{tabular}

\subsubsection{Estimation of recharge by the chloride mass balance}

From the chloride background concentrations, mean recharge fractions were calculated according to Eq. (1). The recharge fraction of total precipitation for the individual class 1 spring catchments ranges from $25 \%$ to $45 \%$, with a median of ca. $36 \%$. The range reflects the small scale variability of the different aquifer strata and land surface properties such as soil thickness, soil hydraulic properties, slope, vegetation cover, and presence of manmade terraces, in combination with the local precipitation depth. The data were grouped according to the geological strata from where the springs emerge (Fig. 3.8). The Albian layers display high recharge fractions of about $40 \%$. The Cenomanian layers display somehow lower fractions of about $30 \%$. In numerical groundwater modelling studies of perched spring aquifers, Weiss and Gvirtzman (2007) already found a high recharge fraction for an Albian aquifer catchment (average 47\%) relative to catchments in the Cenomanian aquifer (average ca. 26\%).

The recharge fraction range for the class 2 springs still displays the variability of the class 1 springs, or even a slightly larger one (Fig. 3.8), with the upper and lower margins being constituted by the still relatively low discharge springs Fasayil and Fara (Appendix A). Most springs display a recharge fraction around 35\%. The springs Sultan and Duyuk display a fraction of ca. $40 \%$. In general, the calculated recharge fractions are relatively high values for semi-arid conditions compared to other studies who usually derived fractions of a few percent (e.g. Edmunds and Gaye, 1994; Wood and Sanford, 1995; Scanlon et al., 2006). They may be attributed to the karstic nature of the outcropping formations. Andreo et al. (2008) reported recharge fractions between $33 \%$ and $55 \%$ for a number of carbonate aquifers in Southern Spain (partly semi-arid). Hoetzl (1995) reported similarly high values even under arid conditions as a result of 
focussed infiltration into sinkholes. Also in this study area, the very high recharge rates might be a result of a higher percentage of focussed recharge, for example along the course of the ephemeral valleys.

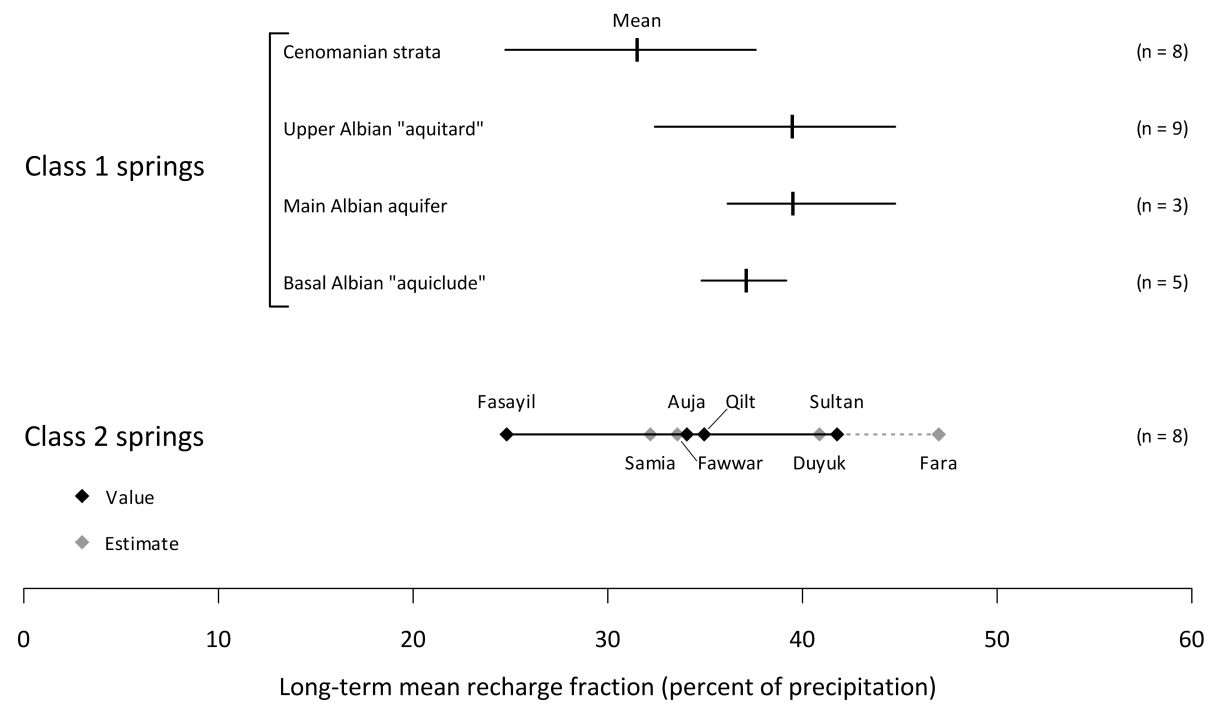

Fig. 3.8: Recharge fractions estimated for the springs of class 1 and 2 . For the class 1 springs, the range of data and the mean value are displayed.

The mean groundwater recharge fractions derived by the chloride mass balance are in accordance with values obtained by applying empirical methods (Section 3.3.4). The spatial distribution of precipitation over the recharge area of the carbonate aquifer system is variable, but the Jerusalem meteorological station is estimated to display a representative value. The annual precipitation depth at Jerusalem station ranged between 210 and $1130 \mathrm{~mm}$ for the hydrological years of 19682000. The calculated yearly recharge fraction (Eqs (2)-(4)) was $15-55 \%$ of the precipitation. The calculated volume weighted mean recharge fraction was $34 \%$ during this period.

\subsubsection{Estimation of the wastewater-borne fraction of discharge for the class 2 springs}

The recent sampling was conducted during different spring flow regimes. Autumn samples (September 2011 and 2012) were collected each year many months after the last major precipitation event in the area. Therefore, no rapid flow component should be recognisable in those samples. Because all hydrological years from 2006 to 2011 were characterised by less than average annual precipitation values, relatively low discharge values were observed at the springs in September 2011. Samples from March 2011 and March 2012 are representative for the winter periods. The winter season of 2011/2012 was characterised by a larger than average precipitation depth. Therefore, high spring discharge was observed in March 2012. The wastewater-borne fraction present in the spring discharge was calculated from the recent chloride concentrations according to Eq. (3.5) and is listed in Table 3.6.

The standard deviations of the chloride time series ranged between 1.9 and $3.7 \mathrm{mg} \mathrm{l}^{-1}$ (Table 3.5). For the Fasayil and Samia springs and certain samples of the Auja spring, the difference between sample concentration and estimated natural background concentrations is within the range of two standard deviations. For those samples, an anthropogenic contribution cannot be determined 
unambiguously. For the springs in Wadi Qilt and in and near Jericho, the recent chloride concentrations are significantly higher than the estimated natural background concentrations. The increase is 3 to 16 times the standard deviation, demonstrating a significant rise. The calculated wastewater fraction ranges from ca. 4\% for Qilt spring to ca. 20\% for Fawwar spring. The springs Sultan, Duyuk, and Fara display wastewater-borne proportions of ca. $10 \%$. Since precipitation is largely confined to the winter months of October to April, also a separate analysis of the time series data from springtime and autumn samples was performed. The analysis yielded no large differences in trend and mean concentration for most springs. Only for Fawwar spring, which displayed the largest discharge fluctuations of all class 2 springs ( $Q: 0-25001 \mathrm{~s}^{-1}$ ), the chloride concentration increase (1968-1998) was considerably larger for the autumn samples (generally low flow conditions) compared to the spring samples (high flow conditions). Hence, the anthropogenic flow fraction was more diluted for high discharge conditions. In contrast, Auja spring displayed a wastewater fraction of $7 \%$ during high flow conditions, whereas during low flow conditions only a low and statistically not significant fraction was calculated (Table 3.6). Therefore, especially for the Fawwar and Auja springs, a higher sampling frequency is recommended.

Table 3.6: Sampling results for the class 2 springs. The calculated discharge fraction (Eq. (3.5)) due to waste-water infiltration $\left(F_{\mathrm{ww}}\right)$ is based on the calculated background values from Table 3.5. Furthermore, the mass ratios of the halide anions are calculated.

\begin{tabular}{|c|c|c|c|c|c|c|c|c|c|}
\hline Spring & $\begin{array}{l}\text { Sample } \\
\text { date }\end{array}$ & $\begin{array}{c}\mathrm{Cl}^{-} \\
\left(\mathrm{mg} \mathrm{l}^{-1}\right)\end{array}$ & $\begin{array}{c}\mathrm{Br}^{-} \\
\left(\mathrm{mg} \mathrm{l}^{-1}\right)\end{array}$ & $\begin{array}{c}\mathrm{I}^{-} \\
\left(\mathrm{mg} \mathrm{l}^{-1}\right)\end{array}$ & $\begin{array}{c}\mathrm{NO}^{3-} \\
\left(\mathrm{mg} \mathrm{l}^{-1}\right)\end{array}$ & $\begin{array}{l}F_{\mathrm{ww}} \\
(\%)^{\mathrm{a}}\end{array}$ & $\begin{array}{c}\text { Discharge } \\
\left(1 \mathrm{~s}^{-1}\right)^{\mathrm{c}}\end{array}$ & $\begin{array}{c}\mathrm{Cl}^{-} / \mathrm{Br}^{-} \\
\text {mass ratio }\end{array}$ & $\begin{array}{c}\mathrm{Cl}^{-} / \mathrm{I}^{-} \\
\text {mass ratio }\end{array}$ \\
\hline \multirow[t]{2}{*}{ Farab $^{b}$} & 06.09 .2011 & 45 & & & 23 & 9 & low & & \\
\hline & 03.09.2012 & 45 & 0.16 & 0.009 & & 9 & $\sim 25$ & 280 & 5000 \\
\hline \multirow[t]{3}{*}{ Fawwar ${ }^{b}$} & 06.09.2011 & 86 & & & 31 & 22 & low & & \\
\hline & 09.03.2012 & 52 & & & 33 & 9 & $\sim 2000$ & & \\
\hline & 02.09.2012 & 80 & 0.27 & 0.015 & & 20 & $\sim 100$ & 300 & 5400 \\
\hline Qilt & 08.09.2011 & 38 & 0.14 & & 19 & 4 & & 270 & \\
\hline \multirow[t]{3}{*}{ Sultan } & 12.03 .2011 & 57 & & & 38 & 12 & 180 & & \\
\hline & 12.09 .2011 & 46 & 0.16 & & 26 & 8 & 160 & 290 & \\
\hline & 04.09.2012 & 47 & 0.17 & 0.010 & & 9 & 180 & 280 & 4700 \\
\hline \multirow[t]{2}{*}{ Duyuk } & 16.03 .2011 & 54 & & & 35 & 11 & & & \\
\hline & 04.09.2012 & 47 & 0.17 & 0.010 & & 9 & 250 & 280 & 4700 \\
\hline \multirow[t]{3}{*}{ Auja } & 16.03 .2011 & 33 & & & 21 & (2) & 200 & & \\
\hline & 03.03.2012 & 46 & & & 28 & 7 & 510 & & \\
\hline & 05.09.2012 & 31 & 0.12 & 0.009 & & (1.4) & 53 & 260 & 3500 \\
\hline \multirow[t]{3}{*}{ Samiab $^{b}$} & 10.09 .2011 & 32 & & & 29 & $(0.9)$ & pumped & & \\
\hline & 09.03.2012 & 29 & & & 19 & $(-0.2)$ & 110 & & \\
\hline & 02.09.2012 & 30 & 0.10 & 0.007 & & $(0.3)$ & pumped & 300 & 4300 \\
\hline Fasayil & 08.09.2011 & 37 & & & 19 & $(-0.6)$ & & & \\
\hline
\end{tabular}

a Values in brackets: chloride concentration within two standard deviations from the background value (Table 3.5).

b For some springs the background values are unsure. In this case, the conservative values were used for calculation. Therefore, the calculated wastewater fraction could be higher in case of a lower background concentration.

${ }^{\mathrm{c}}$ Discharge measured by salt dilution method. Values marked with a were estimated by the velocity-area method and intended just for comparison. 
Since the chloride concentrations for the springs displayed an increasing trend and even a larger increase during recent years, it can be assumed that maximum chloride concentrations in spring water are not reached yet, i.e. the anthropogenic contributions to current groundwater recharge are expected to be higher than calculated by the recent samples. A high residence time of chloride in groundwater systems is supported by isotope studies (Kroitoru, 1987; Lange, 2012), which reveal a long-term flow component in the aquifer systems, indicating large aquifer storage. Because the input function is unknown, a long-term prediction of chloride concentration is not possible.

\subsubsection{Quantitative effects on spring discharge?}

A discontinuous 80-year discharge time series is available for Sultan spring. Despite discharge fluctuations due to differences in seasonal and long-term recharge, the linear regression line displays no trend (Fig. 3.6). The expressed long-term constant discharge can be explained by the postulated underflow mechanism (Rosenthal and Kronfeld, 1982), with the Sultan spring as the lowest outlet to a larger carbonate aquifer system. According to the results of Section 3.4.4, Duyuk spring is expected to be part of this system. For Duyuk spring, a linear regression analysis of the time series data from 1967 to 2000 yields an annual increase of ca. 1.1\%. For Auja spring for the same period a decrease of $1.3 \% \mathrm{a} \mathrm{a}^{-1}$ is calculated. Nevertheless, because of the variability of natural recharge, these 33-year time series might still be insufficient for the identification of a long-term recharge trend. Because of data gaps, no similar analysis can be made for the Wadi Qilt springs. Therefore, the considerable quantity of wastewater-borne groundwater recharge, established by hydrochemical data, is not equivalent reported by discharge data.

\subsection{Conclusions}

Long-term monitoring of chloride and nitrate in groundwater of several karst springs of the Lower Jordan Valley area allowed the determination of natural background chloride concentrations, groundwater recharge, and anthropogenic impact on groundwater over the last 70 years. Many large springs in the study area display an increasing chloride concentration. Natural background chloride concentrations were calculated from the time series by (1) the exclusion of anthropogenically influenced springs based on nitrate concentration for the small springs and (2) by employing historical data and trend analysis for the large springs. These methods were further subdivided into the approaches "historical data sensu stricto", "trend analysis confirmed by historical data", and "minimum historical concentration". Derived natural background concentrations ranged between 20 and $40 \mathrm{mg} \mathrm{l}^{-1}$. Due to the large variation of the natural background concentrations, attempts to delimit anthropogenically influenced springs statistically from single chloride measurements would not be possible. Mean groundwater recharge fractions of total precipitation were calculated by the chloride mass balance method and ranged between $25 \%$ and $50 \%$ for the investigated karst springs.

The chloride/bromide ratio in spring water was used to exclude a possible admixture of saline 
groundwater in the Jordan Valley to spring flow. The main fraction of anthropogenically added chloride in groundwater is attributed to wastewater infiltration in the outcrop areas of the carbonate aquifers. However, the infiltration of fresh drinking water, landfill leachate, and liquid manure are assumed to contribute to this mass flux. To date, these anthropogenic sources cannot be satisfactorily separated with the available data. For recent spring samples, the fraction of wastewater was calculated by an end-member mixing approach at $0-20 \%$ of spring discharge for individual large springs.

Chloride is a very valuable indicator, because the employed historical data displayed a sufficient accuracy over the period of investigation. In this study, it is shown that with as few as 60 chloride samples per spring over a time span of 70 years, quantitative results regarding the fraction of wastewater present in spring water can be obtained. This point underlines the value of long-term monitoring, even at a comparatively low time resolution (Howden et al., 2010; Burt et al., 2011). Since the chloride concentration of precipitation is temporally and spatially quite variable (e.g. Edmunds and Gaye, 1994), it should be continuously monitored, especially in (semi-)arid environments. The usual small database for precipitation chloride concentration introduces the largest error into the chloride mass balance calculations (e.g. Wood and Sanford, 1995). Furthermore, we agree with Edmunds and Shand (2008b), who state that more effort is needed to assemble archive hydrochemical data and to conserve and interpret them.

For certain springs, the estimated wastewater fraction is highly variable in time. Therefore, a higher sampling frequency and event monitoring is recommended to investigate the role of pulse infiltration. Other wastewater indicator substances such as trace organics (e.g. carbamazepine) are potentially better suited to prove and quantify a minor wastewater impact, because they are not present in the pristine water (Gasser et al., 2010; Hillebrand et al., 2012). However, these indicators potentially display a larger temporal and spatial heterogeneity regarding input concentrations. Therefore, sufficient long and detailed time series have to be established for the differentiation of anthropogenically generated recharge.

\section{Acknowledgements}

The work is conducted within the framework of the multi-lateral research project "SMART Sustainable Management of Available Water Resources with Innovative Technologies" funded by BMBF (German Federal Ministry of Education and Research), references Nos. 02WM0802 and 02WM1081. Special thanks go to: Mustafa Nuseibeh and coworkers for the excellent spring monitoring conducted over more than three decades; without these great efforts, the present study would not have been possible; Deeb Abdelghafour for scientific discussion; Anwar Zuhluf, Hazem Jumaa, Klaus Haaken, Shadha Musallam, Steffen Fischer, and Fabian Ries for support during sampling and fieldwork; Nadine Maier for digitizing work; Joe Nadolski for proofreading the manuscript; Anke von Gaza, Mechthild Rittmeier, and Tobias Licha for chemical analyses. The constructive comments of two anonymous reviewers were of great help in improving the manuscript and are highly acknowledged. 


\section{Appendix A}

Compiled data and calculations for the analysed springs. Data for class 1 springs mainly based on Palestinian Water Authority (2000). Elevated chloride and nitrate concentrations for class 1 springs are shown in bold.

\begin{tabular}{|c|c|c|c|c|c|c|c|}
\hline $\begin{array}{l}\text { Spring } \\
\text { hydrostrat. unit }\end{array}$ & $\begin{array}{l}\text { Spring } \\
\text { ID }\end{array}$ & $\begin{array}{c}\text { Spring } \\
\text { elevation } \\
\text { (m ASL) }\end{array}$ & $\begin{array}{l}\mathrm{Cl}^{-} \text {monitoring } \\
\text { period }\end{array}$ & $\begin{array}{l}\text { Mean } \mathrm{Cl}^{-} \\
\text {conc. } \\
\left(\mathrm{mg} \mathrm{l}^{-1}\right)\end{array}$ & $\begin{array}{c}\text { Mean } \mathrm{NO}_{3}^{-} \\
\text {conc. }^{a} \\
\left(\mathrm{mg} \mathrm{l}^{-1}\right)\end{array}$ & $\begin{array}{c}\text { Mean } \\
\text { discharge } \\
\left(\mathrm{l} \mathrm{s}^{-1}\right)\end{array}$ & $\begin{array}{c}\text { Recharge } \\
\text { fraction } \\
(\% \text { of } P)\end{array}$ \\
\hline \multicolumn{8}{|l|}{ Class 1 springs } \\
\hline Turonian & Gihon & 650 & 1973-1997 & 230 & 190 & 18 & \\
\hline Cenomanian & BA/092 & 800 & 1969-1998 & 31 & 7 & 0.15 & 30 \\
\hline Cenomanian & BA/093 & 640 & 1969-1998 & 35 & 29 & 0.17 & \\
\hline Cenomanian & BA/096 & 790 & 1973-1998 & 33 & 10 & 0.16 & 28 \\
\hline Cenomanian & BA/102 & 790 & 1969-1998 & 38 & 3 & - & 25 \\
\hline Cenomanian & $\mathrm{BA} / 112$ & 460 & 1984-1998 & 30 & 5 & 0.19 & 31 \\
\hline Cenomanian & BA/117 & 485 & 1975-1998 & 29 & 8 & 0.77 & 32 \\
\hline Cenomanian & $\mathrm{BA} / 120$ & 290 & 1968-1998 & 25 & 6 & 3.5 & 38 \\
\hline Cenomanian & $\mathrm{BA} / 121$ & 255 & 1968-1998 & 28 & 4 & 9.6 & 34 \\
\hline Cenomanian & BA/122 & 300 & 1968-1998 & 28 & 6 & 0.56 & 34 \\
\hline Cenomanian & BA/137 & 500 & 1969-1998 & 118 & 123 & 0.13 & \\
\hline Alb. aquitard & BA/088 & 500 & 1969-1998 & 27 & 11 & 0.55 & 35 \\
\hline Alb. aquitard & BA/106 & - & 1972-1995 & 24 & 5 & 0.05 & 39 \\
\hline Alb. aquitard & $\mathrm{BA} / 108$ & 570 & 1969-1998 & 24 & 7 & 0.58 & 39 \\
\hline Alb. aquitard & BA/109 & 550 & 1976-1998 & 27 & 11 & 0.98 & 35 \\
\hline Alb. aquitard & BA/110 & 525 & 1969-1998 & 29 & 4 & 1.2 & 32 \\
\hline Alb. aquitard & BA/126 & 750 & 1968-1998 & 22 & 5 & 0.24 & 43 \\
\hline Alb. aquitard & $\mathrm{BA} / 127$ & 760 & 1968-1998 & 21 & 4 & 0.23 & 45 \\
\hline Alb. aquitard & $\mathrm{BA} / 128$ & 750 & 1968-1998 & 21 & 7 & 0.47 & 45 \\
\hline Alb. aquitard & BA/129 & 740 & 1968-1998 & 22 & 4 & 0.19 & 43 \\
\hline Alb. aquitard & BA/130 & 630 & 1968-1998 & 46 & 26 & 0.15 & \\
\hline Alb. aquitard & BA/132 & 640 & 1968-1998 & 50 & 35 & 0.24 & \\
\hline Alb. aquitard & $\mathrm{BA} / 135 \mathrm{~A}$ & 645 & 1969-1995 & 58 & 65 & 1.1 & \\
\hline Alb. aquitard & BA/138 & 730 & 1969-1998 & 56 & 53 & 0.61 & \\
\hline Alb. aquitard & BA/139 & 745 & 1971-1998 & 44 & 45 & 0.32 & \\
\hline Albian aquifer & $\mathrm{BA} / 111$ & 430 & 1968-1998 & 40 & 43 & 1.4 & \\
\hline Albian aquifer & BA/144 & 730 & 1969-1998 & 21 & 5 & 0.17 & 45 \\
\hline Albian aquifer & $\mathrm{BA} / 170$ & 535 & 1968-1998 & 25 & 3 & 6.6 & 38 \\
\hline Albian aquifer & BA/171 & 515 & 1968-1998 & 36 & 15 & 5.4 & \\
\hline Albian aquifer & $\mathrm{BA} / 172$ & 600 & 1997-1998 & 26 & 7 & 1.5 & 36 \\
\hline Alb. aquiclude & BA/152 & 670 & 1968-1998 & 48 & 42 & 0.86 & \\
\hline Alb. aquiclude & BA/153 & 670 & 1968-1998 & 25 & 4 & 2.5 & 38 \\
\hline Alb. aquiclude & $\mathrm{BA} / 163$ & 510 & 1968-1998 & 27 & 5 & - & 35 \\
\hline Alb. aquiclude & BA/164 & 500 & 1968-1998 & 27 & 4 & 8.1 & 35 \\
\hline Alb. aquiclude & BA/165 & 560 & 1968-1998 & 24 & 2 & 0.37 & 39 \\
\hline Alb. aquiclude & $\mathrm{BA} / 167$ & 525 & 1968-1998 & 24 & 2 & 1.4 & 39 \\
\hline
\end{tabular}




\begin{tabular}{|c|c|c|c|c|c|c|c|}
\hline $\begin{array}{l}\text { Spring } \\
\text { hydrostrat. unit }\end{array}$ & $\begin{array}{l}\text { Spring } \\
\text { name }\end{array}$ & $\begin{array}{l}\text { Spring } \\
\text { elevation } \\
(\mathrm{m} \mathrm{ASL})\end{array}$ & $\begin{array}{c}\mathrm{Cl}^{-} \text {monitoring } \\
\text { period }\end{array}$ & $\begin{array}{c}\mathrm{Cl}^{-} \\
\mathrm{NBC}^{\mathrm{b}} \\
\left(\mathrm{mg} \mathrm{l}^{-1}\right) \\
\end{array}$ & $\begin{array}{c}\text { Mean } \mathrm{NO}_{3}^{-} \\
\text {concentr. }^{\mathrm{a}} \\
\left(\mathrm{mg} \mathrm{l}^{-1}\right)\end{array}$ & $\begin{array}{c}\text { Mean } \\
\text { discharge } \\
\left(1 \mathrm{~s}^{-1}\right) \\
\end{array}$ & $\begin{array}{c}\text { Recharge } \\
\text { fraction } \\
(\% \text { of } P)\end{array}$ \\
\hline \multicolumn{8}{|l|}{ Class 2 springs } \\
\hline Turonian & Fara $^{c}$ & 290 & $194 x-2012$ & $(20)$ & 14 & $45^{c}$ & $(47)$ \\
\hline Turonian & Fawwar & 75 & 1954-2012 & (28) & 20 & $140^{\mathrm{d}}$ & (34) \\
\hline Turonian & Qilt ${ }^{\mathrm{d}}$ & 10 & 1946-2011 & 27 & 13 & $130^{\mathrm{d}}$ & 35 \\
\hline unknown & Sultan & -215 & 1938-2012 & 23 & 18 & 180 & 42 \\
\hline unknown & Duyuke & -110 & 1941-2012 & 23 & 18 & $260^{e}$ & 41 \\
\hline Cen./Alb. (?) & Auja & 20 & 1945-2012 & 28 & 11 & 290 & 34 \\
\hline Cenomanian & Samia $^{f}$ & 440 & 1962-2012 & (29) & 21 & $21^{\mathrm{f}}$ & $(32)$ \\
\hline Cen./Alb. (?) & Fasayil & -110 & 1941-2011 & 38 & 16 & 21 & 25 \\
\hline
\end{tabular}

a Mean nitrate concentration during monitoring period 1982-1998.

${ }^{b}$ NBC: approximated natural background concentration. Values in brackets are unsure.

c Three hydrochemical similar springs (Fara, Jummaizah and Ruyan) are located in the same area. Fara is the uppermost outlet and displaying the largest discharge. The combined discharge of the three outlets is given.

d Discharge for both springs can only be given as tentative values.

e Combined discharge of the springs Duyuk, Nueima, and Shosah. Those are hydrochemical identical outlets, located a few meters apart. They are treated sometimes as individual springs, especially for water rights aspects.

f Samia spring discharge values refer to pumping abstraction values of nearby well Ein Samia No. 1 . About 100 meters from the Samia spring, a 60 m deep dug well was constructed in 1964/65, tapping the spring's aquifer. Since then, the spring is actively managed and is therefore dry for most of the year. However, the total discharge values of the well are estimated to be close to the springflow for unmanaged conditions.

\section{References}

Abu-Alrub, I., Joma, A., Christianse, J.L., 2004. Production methods and farming systems in major barley (Hordeum vulgare) growing regions of the West Bank, Palestine. Experimental Agriculture 40, 179-188.

Abu Sharkh, M.S., 2008. Adapting low cost wastewater treatment technologies for rural areas in the West Bank. Twelfth International Water Technology Conference, IWTC12 2008, Alexandria, 1441-1454.

Albaiges, J., Casado, F., Ventura, F., 1986. Organic indicators of groundwater pollution by a sanitary landfill. Water Research 20, 1153-1159.

Alcalá, F.J., Custodio, E., 2008. Using the $\mathrm{Cl} / \mathrm{Br}$ ratio as a tracer to identify the origin of salinity in aquifers in Spain and Portugal. Journal of Hydrology 359, 189-207.

Al-Khatib, I.A., Arafat, H.A., Basheer, T., Shawahneh, H., Salahat, A., Eid, J., Ali, W., 2007. Trends and problems of solid waste management in developing countries: a case study in seven Palestinian districts. Waste Management 27, 1910-1919.

Amiel, R.B., Grodek, T., Frumkin, A., 2010. Characterization of the hydrogeology of the sacred Gihon Spring, Jerusalem: a deteriorating urban karst spring. Hydrogeology Journal 18, 1465-1479. 
Andreo, B., Vías, J., Durán, J.J., Jiménez, P., López-Geta, J.A., Carrasco, F., 2008. Methodology for groundwater recharge assessment in carbonate aquifers: application to pilot sites in southern Spain. Hydrogeology Journal 16, 911-925.

ANTEA, 1998. Well development study of the Eastern Aquifer Basin, northern districts of Palestine, Volume 1: Interim report, conceptual model. Unpublished ANTEA report No. A11903.

Appelo, C.A.J., Postma, D., 2005. Geochemistry, groundwater and pollution, 2nd edition. Balkema, Leiden, ISBN: 0-415-36428-0.

Bachi, R., 1974. The population of Israel. C.I.C.R.E.D. World Population Year Series, Jerusalem.

Barrett, M.H., Hiscock, K.M., Pedley, S., Lerner, D.N., Tellam, J.H., French, M.J., 1999. Marker species for identifying urban groundwater recharge sources: a review and case study in Nottingham, UK. Water Research 33, 3083-3097.

Begin, Z.B., 1975. The geology of the Jericho sheet. Geological Survey of Israel, Bulletin 67, Jerusalem.

Blake, G.S., Goldschmidt, M.J., 1947. Geology and Water Resources of Palestine. Government Printer, Jerusalem.

Brinkhoff, T., 2013. City Population. http://www.citypopulation.de (accessed 16.07.2013).

Burt, T.P., Howden, N.J.K., Worrall, F., McDonnel, J., 2011, On the value of long-term, low-frequency water quality sampling: avoiding throwing the baby out with the bathwater. Hydrological Processes 25, 828-830.

Clark, I., Fritz, P., 1997. Environmental isotopes in hydrogeology. Lewis, Boca Raton, ISBN: 1-56670-249-6.

Daghrah, G.A., 2010. Water quality study of Wadi Al Qilt-West Bank-Palestine. Asian Journal of Earth Sciences 3, 169-179.

Davis, S.N., Whittemore, D.O., Fabryka-Martin, J., 1998. Uses of chloride/bromide ratios in studies of potable water. Ground Water 36, 338-350.

Department of Land Settlement and Water Commissioner, 1947a. Water measurements prior to October 1944. British Government of Palestine, Government Printer, Jerusalem.

Department of Land Settlement and Water Commissioner, 1947b. Water measurements 1944/1945. British Government of Palestine, Government Printer, Jerusalem.

Department of Land Settlement and Water Commissioner, 1947c. Water measurements 1945/1946. British Government of Palestine, Government Printer, Jerusalem.

DIN 38405-33, 2001. Deutsche Einheitsverfahren zur Wasser-, Abwasser- und Schlammuntersuchung - Anionen (Gruppe D) - Teil 33: Bestimmung von Iodid mittels Photometrie (D 33). Beuth, Berlin.

Dror, G., Ronen, D., Stiller, M., Nishri, A., 1999. Cl/Br ratios of Lake Kinneret, pore water and associated springs. Journal of Hydrology 225, 130-139.

Edmunds, W.M., Gaye, C.B., 1994. Estimating the spatial variability of groundwater recharge in the Sahel using chloride. Journal of Hydrology 156, 47-59.

Edmunds, W.M., Shand, P., 2008a. Groundwater baseline quality, in: Edmunds, W.M., Shand, P. (Eds.), Natural groundwater quality. Blackwell, Malden, pp. 1-21.

Edmunds, W.M., Shand, P., 2008b. Natural groundwater quality - Summary and significance for water resources management, in: Edmunds, W.M., Shand, P. (Eds.), Natural groundwater quality. Blackwell, Malden, pp. $441-462$.

Einsiedl, F., Radke, M., Maloszewski, P., 2010. Occurrence and transport of pharmaceuticals in a karst 


\section{Quantification of long-term wastewater impacts}

groundwater system affected by domestic wastewater treatment plants. Journal of Contaminant Hydrology 117, 26-36.

Eriksson, E., Khunaksem, V., 1969. Chloride concentration in ground water, recharge rate and rate of deposition of chloride in the Israel coastal plain. Journal of Hydrology 7, 178-197.

Executive Action Team, 2000. Temporal trends for water-resources data in areas of Israeli, Jordanian, and Palestinian Interest. Middle East Water Data Banks Project, compiled by the U.S. Geological Survey, http://exact-me.org/trends/index.htm (accessed 16.07.2013).

Foster, S.S.D., Chilton, P.J., 2003. Groundwater: the processes and global significance of aquifer degradation. Philosophical Transactions of the Royal Society of London B 358, 1957-1972.

Gasser, G., Rona, M., Voloshenko, A., Shelkov, R., Tal, N., Pankratov, I., Elhanany, S., Lev, O., 2010. Quantitative evaluation of tracers for quantification of wastewater contamination of potable water sources. Environmental Science and Technology 44, 3919-3925.

Godwin, K.S., Hafner, S.D., Buff, M.F., 2003. Long-term trends in sodium and chloride in the Mohawk River, New York: The effect of fifty years of road-salt application. Environmental Pollution 124, 273-281.

Goldschmidt, M.J., 1959. On the water balances of several mountain underground water catchments in Israel and their flow patterns. Hydrological Service, Hydrological Paper No. 4, Jerusalem.

Griffioen, J., Passier, H.F., Klein, J., 2008. Comparison of selection methods to deduce natural background levels for groundwater units. Environmental Science and Technology 42, 4863-4869.

Guttman, J., 2000. Multi-Lateral Project, Final Report 1997-2000, Sub Project B: Hydrogeology of the Eastern Aquifer in the Judea Hills and Jordan Valley. Mekorot report No. 468, Tel Aviv, Israel.

Guttman, J., Zuckerman, H., 1995. Flow model in the eastern basin of the Judea and Samaria hills. Tahal Consulting Engineers Ltd., Report No. 01/95/66, Tel Aviv. (in Hebrew).

Hasan, J., Guttman, J., 2012. Delineation of protection zones in selected areas to demonstrate feasibility - Study area: Wadi Al Qilt and Jericho sub basin. Unpublished report, BMBF research project SMART.

Healy, R.W., 2010. Estimating groundwater recharge. Cambridge University Press, Cambridge.

Helsel, D.R., Mueller, D.K., Slack, J.R., 2006. Computer program for the Kendall family of trend tests. U.S. Geological Survey Scientific Investigations Report 2005-5275, Reston.

Herut, B., Starinsky, A., Katz, A., Rosenfeld, D., 2000. Relationship between the acidity and chemical composition of rainwater and climatological conditions along a transition zone between large deserts and Mediterranean climate, Israel. Atmospheric Environment 34, 1281-1292.

Hillebrand, O., Nödler, K., Licha, T., Sauter, M., Geyer, T., 2012. Caffeine as an indicator for the quantification of untreated wastewater in karst systems. Water Research 46, 395-402.

Hoetzl, H., 1995. Groundwater recharge in an arid karst area (Saudi Arabia). IAHS Publication 232, $195-207$.

Howden, N.J.K., Burt, T.P., Worrall, F., Whelan, M.J., Bieroza, M., 2010. Nitrate concentrations and fluxes in the River Thames over 140 years (1868-2008): are increases irreversible? Hydrological Processes 23, 26572662.

Katz, B.G., Eberts, S., Kauffman, L., 2011. Using Cl/Br ratios and other indicators to assess potential impacts on groundwater quality from septic systems: A review and examples from principal aquifers in the United States, Journal of Hydrology 397, 151-166.

Katz, B.G., Griffin, D.W., Davis, J.H., 2009. Groundwater quality impacts from the land application of treated 
municipal wastewater in a large karstic spring basin: Chemical and microbiological indicators. Science of the Total Environment 407, 2872-2886.

Kelly, W.R., Panno, S.V., 2008. Some considerations in applying background concentrations to ground water studies. Ground Water 46, 790-792.

Kelly, W.R., Panno, S.V., Hackley, K.C., Hwang, H.H., Martinsek, A.T., Markus, M., 2010. Using chloride and other ions to trace sewage and road salt in the Illinois Waterway. Applied Geochemistry 25, 661-673.

Khayat, S., Geyer, S., Hötzl, H., Ghanem, M., Ali, W., 2006. Identification of nitrate sources in groundwater by

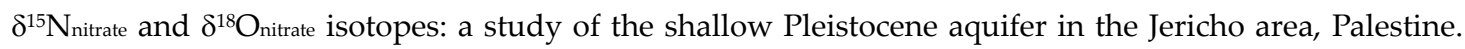
Acta Hydrochimica et Hydrobiologica 34, 27-33.

Kjeldsen, P., Barlaz, M.A., Rooker, A.P., Baun, A., Ledin, A., Christensen, T.H., 2002. Present and long-term composition of MSW landfill leachate: a review. Critical Reviews in Environmental Science and Technology 32, 297-336.

Klein Tank, A.M.G., Wijngarrd, J.B., Konnen, G.P., Bohm, R., Demaree, A., Gocheve, M., Mileta, S., Pashiardis, L., Hejkrlik, C., Kern-Hansen, R., Heino, P., Bessemoulin, G., Muller-Westermeier, G., Tzanakou, M., Szalai, S., Palsdottir, D., Fitzgerald, D., Rubin, S., Capaldo, M., Maugeri, M., Leitass, A., Bukantis, A., Aberfeld, R., van Engelen, A.F.V., Forland, E., Mietus, M., Coelho, F., Mares, C., Razuvaev, V., Nieplova, E., Cegnar, T., López, J.A., Dahlstrom, B., Moberg, A., Kirchhofer, W., Ceylan, A., Pachaliuk, O., Alexander, L.V., Petrovic, P., 2002. Daily dataset of $20^{\text {th }}$-century surface air temperature and precipitation series for the European Climate Assessment. International Journal of Climatology 22, 1441-1453.

Kroitoru, L., 1987. The characterization of flow systems in carbonatic rocks defined by the ground water parameters, Central Israel. PhD thesis, Weizmann Institute of Science, Rehovot.

Lange, T., 2012. Tracing flow and salinization processes at selected locations of Israel and the West Bank - the Judea Group aquifer and the shallow aquifer of Jericho. PhD Thesis. Freiberg Online Geoscience 31. $<$ http://tu-freiberg.de/geo/fog>.

Leibundgut, C., Maloszewski, P., Külls, C., 2009. Tracers in hydrology. Wiley-Blackwell, Chichester, ISBN: 978-0470-51885-4.

Lenz, R., 1969. Eine Strukturkarte von Westjordanien im Maßstab 1 : 250 000. Beihefte zum Geologischen Jahrbuch 81, 93-112.

Lerner, D.N., Issar, A., Simmers, I., 1990. Groundwater recharge: a guide to understanding and estimating natural recharge. IAH, International Contributions to Hydrogeology 8, Heise, Hannover, ISBN: 3-922705-91-X.

Limbrick, K.J., 2003. Baseline nitrate concentration in groundwater of the Chalk in south Dorset, UK. The Science of the Total Environment 314-316, 89-98.

Marei, A., Khayat, S., Weise, S., Ghannam, S., Sbaih, M., Geyer, S., 2010. Estimating groundwater recharge using the chloride mass-balance method in the West Bank, Palestine. Hydrological Sciences Journal 55, 780791.

Marie, A., Vengosh, A., 2001. Sources of salinity in groundwater from Jericho area, Jordan Valley. Ground Water $39,240-248$.

McCarthy, J., 1990. The Population of Palestine: History and Statistics of the Late Ottoman Period and the Mandate. Columbia University Press, New York.

Mendizabal, I., Baggelaar, P.K., Stuyfzand, P.J., 2012. Hydrochemical trends for public supply well fields in the Netherlands (1898-2008), natural backgrounds and upscaling to groundwater bodies. Journal of Hydrology 450-451, 279-292. 


\section{Quantification of long-term wastewater impacts}

Möller, P., Rosenthal, E., Geyer, S., Flexer, A., 2007. Chemical evolution of saline waters in the Jordan-Dead sea transform and in adjoining areas. International Journal of Earth Sciences 96, 541-566.

Morris, B.L., Lawrence, A.R.L., Chilton, P.J.C., Adams, B., Calow, R.C., Klinck, B.A., 2003. Groundwater and its susceptibility to degradation: A global assessment of the problem and options for management. Early Warning and Assessment Report Series, RS. 03-3. United Nations Environment Programme, Nairobi, ISBN: 92-807-2297-2.

Morris, A.W., Riley, J.P., 1966. The bromide/chlorinity and sulphate/chlorinity ratio in sea water. Deep Sea Research and Oceanographic Abstracts 13, 699-705.

Mudarra, M., Andreo, B., Mudry, J., 2012. Monitoring groundwater in the discharge area of a complex karst aquifer to assess the role of the saturated and unsaturated zones. Environmental Earth Sciences 65, 23212336.

Nuseibeh, M., Nasser Eddin, T., 1995. Palestinian fresh water springs. Palestinian Consultancy Group, Jerusalem.

Palestinian Central Bureau of Statistics, 2009. Population, housing and establishment census 2007. Palestinian Central Bureau of Statistics report, Ramallah.

Palestinian Water Authority, 2000. Summary of Palestinian hydrologic data, Volume 1: West Bank. Palestinian Water Authority report, Ramallah.

Panno, S.V., Hackley, K.C., Hwang, H.H., Greenberg, S.E., Krapac, I.G., Landsberger, S., O’Kelly, D.J., 2006. Characterization and identification of $\mathrm{Na}-\mathrm{Cl}$ sources in ground water. Ground Water 44, 176-187.

Paul, M., Wolf, L., Fund, K., Held, I., Winter, J., Eiswirth, M., Gallert, C., Hötzl, H., 2004. Microbiological condition of urban groundwater in the vicinity of leaky sewer systems. Acta Hydrochimica et Hydrobiologica 32, 351-360.

Pinder, G.F., Jones, J.F., 1969. Determination of the ground-water component of peak discharge from the chemistry of total runoff. Water Resources Research 5, 438-445.

Rofe \& Raffety Consulting Engineers, 1963. Jerusalem and district water supply: geological and hydrological report. Report to the Central Water Authority of the Hashemite Kingdom of Jordan. London.

Rofe \& Raffety Consulting Engineers, 1965. Nablus district water resources survey: geological and hydrological report. Report to the Central Water Authority of the Hashemite Kingdom of Jordan. London.

Rosenan, N., 1955. One hundred years of rainfall in Jerusalem: a homotopic series of annual amounts. Israel Exploration Journal 5, 137-153.

Rosenthal, A., Kronfeld, J., 1982. ${ }^{234} \mathrm{U}-238 \mathrm{U}$ disequilibria as an aid to the hydrological study of the Judea Group aquifer in eastern Judea and Samaria, Israel. Journal of Hydrology 58, 149-158.

Scanlon, B.R., Healy, R.W., Cook, P.G., 2002. Choosing appropriate techniques for quantifying groundwater recharge. Hydrogeology Journal 10, 18-39.

Scanlon, B.R., Keese, K.E., Flint, A.L., Flint, L.E., Gaye, C.B., Edmunds, W.M., Simmers, I., 2006. Global synthesis of groundwater recharge in semiarid and arid regions. Hydrological Processes 20, 3335-3370.

Schilman, B., Teplyakov, N., Gavrieli, I., 2004. Identification of nitrate contamination sources in groundwater using nitrogen and oxygen isotopes in nitrate: Wadi Kelt-Jericho area as a case study. Report GSI/25/2004, Geological Survey of Israel, Jerusalem. (in Hebrew).

Schoeller, H., 1960. Salinité des eaux souterraines, évapotranspiration et alimentation des nappes. IAHS Publication 52, 488-494. 
Shachnai, E., 2000. The Geological Map of Israel, 1:50,000, Ramallah. Geological Survey of Israel, Jerusalem.

Sneh, A., Bartov, Y., Weissbrod, T., Rosensaft, M., 1998. Geological map of Israel, 1:200,000. Geological Survey of Israel, on-line geological map, Jerusalem. <http://www.gsi.gov.il>.

Tiehm, A., Schmidt, N., Stieber, M., Sacher, F., Wolf, L., Hoetzl, H., 2011. Biodegradation of pharmaceutical compounds and their occurrence in the Jordan Valley. Water Resources Management 25, 1195-1203.

UNESCO, 1979. Map of the world distribution of arid regions. MAB Technical Notes 7, United Nations Educational, Scientific and Cultural Organization, Paris.

Vadillo, I., Carrasco, F., Andreo, B., Garcia de Torres, A., Bosch, C., 1999. Chemical composition of landfill leachate in a Karst area with a Mediterranean climate (Marbella, southern Spain). Environmental Geology 37, 326-332.

Vengosh, A., Keren, R., 1996. Chemical modifications of groundwater contaminated by recharge of sewage effluent. Journal of Contaminant Hydrology 23, 347-360.

Weiss, M., Gvirtzman, H., 2007. Estimating ground water recharge using flow models of perched karstic aquifers. Ground Water 45, 761-773.

Wendland, F., Blum, A., Kunkel, R., 2006. Approach to assess natural background levels (NBLs), in: Müller, D., Blum., A., Hart, A., Hookey, J., Kunkel, R., Scheidleder, A., Tomlin, C., Wendland, F., Final proposal for a methodology to set up groundwater threshold values in Europe. Deliverable 18, project BRIDGE, http://www.wfd-bridge.net (accessed 16.07.2013), pp. 26-32.

Wilson, G.R., Wozab, D.H., 1954. Chemical quality of waters occurring in the Jordan Valley area. IAHS Publication 37, 170-178.

Wolf, L., Zwiener, C., Zemann, M., 2012. Tracking artificial sweeteners and pharmaceuticals introduced into urban groundwater by leaking sewer networks. Science of the Total Environment 430, 8-19.

Wolfer, J., 1998. Hydrogeological investigation along the Jerusalem - Jericho transect (Wadi el Qilt), Israel/West Bank. Diploma thesis, University of Karlsruhe, Karlsruhe.

Wood, W.W., Sanford, W.E., 1995. Chemical and isotopic methods for quantifying ground-water recharge in a regional, semiarid environment. Ground Water 33, 458-468.

Yaalon, D.H., Ganor, E., 1968. Chemical composition of dew and dry fallout in Jerusalem, Israel. Nature 217, 11391140. 
Quantification of long-term wastewater impacts 


\section{Chapter 4}

\section{Characterisation and modelling of conduit restricted karst aquifers - Example of the Auja spring, Jordan Valley}

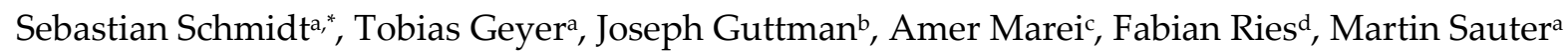

Publication:

Schmidt, S., Geyer, T., Guttman, J., Marei, A., Ries, F., Sauter, M., 2014. Characterisation and modelling of conduit restricted karst aquifers - Example of the Auja spring, Jordan Valley. Journal of Hydrology 511, 750-763.

a University of Göttingen, Geoscience Centre, Applied Geology, Goldschmidtstraße 3, 37077 Göttingen, Germany

b Mekorot, Israel National Water Company, 9 Lincoln St., Tel Aviv 61201, Israel

c Al-Quds University, Department of Earth and Environmental Studies, P.O.B. 20002, Jerusalem, West Bank, Palestine

d University of Freiburg, Chair of Hydrology, Fahnenbergplatz, 79098 Freiburg, Germany

* Corresponding author. Tel.: +49 551 399333; fax: +49 551399379

E-mail address: Sebastian.Schmidt@geo.uni-goettingen.de 


\section{Summary}

The conduit system of mature karstified carbonate aquifers is typically characterised by a high hydraulic conductivity and does not impose a major flow constriction on catchment discharge. As a result, discharge at karst springs is usually flashy and displays pronounced peaks following recharge events. In contrast, some karst springs reported in literature display a discharge maximum, attributed to reaching the finite discharge capacity of the conduit system (flow threshold). This phenomenon also often leads to a non-standard recession behaviour, a so called "convex recession", i.e. an increase in the recession coefficient during flow recession, which in turn might be used as an indicator for conduit restricted aquifers. The main objective of the study is the characterisation and modelling of those hydrogeologically challenging aquifers. The applied approach consists of a combination of hydrometric monitoring, a spring hydrograph recession and event analysis, as well as the setup and calibration of a non-linear reservoir model. It is demonstrated for the Auja spring, the largest freshwater spring in the Lower Jordan Valley. The semi-arid environment with its short but intensive precipitation events and an extended dry season leads to sharp input signals and undisturbed recession periods. The spring displays complex recession behaviour, exhibiting exponential (coefficient $\alpha$ ) and linear (coefficient $\beta$ ) recession periods. Numerous different recession coefficients $\alpha$ were observed: $\sim 0.2-0.8 \mathrm{~d}^{-1}$ (presumably main conduit system), $0.004 \mathrm{~d}^{-1}$ (fractured matrix), $0.0009 \mathrm{~d}^{-1}$ (plateau caused by flow threshold being exceeded), plus many intermediate values. The reasons for this observed behaviour are the outflow threshold at $0.47 \mathrm{~m}^{3} \mathrm{~s}^{-1}$ and a variable conduit-matrix cross-flow in the aquifer. Despite system complexity, and hence the necessity of incorporating features such as a flow threshold, conduit-matrix cross-flow, and a spatially variable soil/epikarst field capacity, the developed reservoir model is regarded as relatively simplistic. As a number of required parameters were calculated from the hydrogeological analysis of the system, it requires only six calibration parameters and performs well for the highly variable flow conditions observed. Calculated groundwater recharge in this semi-arid environment displays high interannual variability. For example, during the 45-year simulation period, only five wet winter seasons account for $33 \%$ of the total cumulative groundwater recharge.

\section{I Introduction}

At the catchment scale, the hydraulics of karstified carbonate aquifers are controlled by a network of highly permeable flow features (i.e. karst shafts, karst conduits) embedded in a less permeable fractured rock matrix (e.g. Atkinson, 1977; Király, 2002). The karst conduit system is generally believed to be the result of the coupled process of groundwater flow and carbonate dissolution (e.g. Klimchouk et al., 2000; Liedl et al., 2003). The spatial aquifer structure is influenced by landscape development and climate conditions during aquifer evolution (i.e. paleobase level and paleo-climate). Due to the large contrast in the hydraulic parameter field in karst aquifers and the presence of turbulent flow conditions in the highly permeable structures, the 
characterisation and modelling of those systems is very complex (Király, 2002; Goldscheider and Drew, 2007).

For groundwater resources assessment and management, especially in the more arid environments, prerequisites are the quantification of groundwater recharge and the prediction of groundwater resources, e.g. during periods of drought (Simmers, 1990; Tallaksen and van Lanen, 2004). Groundwater resources prediction usually requires the application of a mathematical model. Linear reservoir models do not imply detailed knowledge about catchment boundaries and internal aquifer structure and are widely applied for the simulation of karst water resources (e.g. Rimmer and Salingar, 2006; Fleury et al., 2007; Geyer et al., 2008; Hartmann et al., 2012a).

Since flow in karstified carbonate aquifers frequently converges to a distinct number of springs, the time series of spring discharge (spring hydrograph) provides integral information about the whole groundwater catchment of the spring. However, the hydrograph is the result of spatially and temporally diverse and superimposed processes (recharge, storage, and flow; Smart and Hobbs, 1986) within the system and therefore the relative contribution of the different processes is often difficult to deconvolute. According to the presence of integrated conduit networks and hence karst system maturity, karst aquifers have been classified into diffuse flow and conduit flow (free flow) end members (White, 1969; Atkinson, 1977). For mature karst aquifers, spring discharge displays a fast response to precipitation events in the recharge area, i.e. a sharply rising limb, an often sharp peak, followed by a strong flood recession and subsequently a more moderate baseflow recession (e.g. Atkinson, 1977; Geyer et al., 2008). Displayed as a semilogarithmic graph, the recession part of the hydrograph can often be described by a sequence of three or more decreasing recession coefficients (Forkasiewicz and Paloc, 1967; Milanovic, 1981; Sauter, 1992). The above authors attributed each recession coefficient to the physical properties of a distinct aquifer section, i.e. conduit system, "intermediate system", and matrix. However, e.g. Smart (1983) and Eisenlohr et al. (1997) showed that intermediate values can also be the result transient flow conditions.

In contrast to the standard recession behaviour, a number of karst spring hydrographs reported in literature display a shoulder in the recession part of the hydrograph, a so called "convex recession" (Smart, 1983; for further examples see below). Different reasons for such discharge behaviour have been discussed (Fig. 4.1). The limited water conveying capacity of the conduit system can lead to a plateau in discharge, regardless of excess groundwater recharge or high aquifer storage (Fig. 4.1a; Smart, 1983; Bonacci, 2001; Herman et al., 2008). The surplus in groundwater can either contribute to aquifer storage or be discharged by an overflow mechanism within the catchment, e.g. an intermittently active overflow spring (Smart, 1983; Bonacci, 2001; Barberá and Andreo, 2012). Alternatively, convex recession behaviour is attributed to an upgradient reservoir of water, such as infiltration from a flooded Polje (Bonacci, 1993; Fig. 4.1b), infiltration from an alluvial aquifer drained by the karst aquifer (Soulios, 1991) or from high porosity sections within the karst aquifer ("cave", Bonacci, 1993; "constricted reservoirs", Wong et al., 2012).

The interaction and water exchange between the conduits and the fractured matrix under variable hydraulic conditions is increasingly considered in karst hydrogeology (e.g. Bauer et al., 2003; De Rooij, 2008; Maréchal et al., 2008; Bailly-Comte et al., 2010; Reimann et al., 2014). Kovacs 
et al. (2005) distinguished a matrix restricted and a conduit influenced flow regime. Bailly-Comte et al. (2010) showed that the drainage of a conduit system without matrix contribution may produce a linear recession hydrograph (Fig. 4.1c), similar to the outflow of a reservoir of infinite hydraulic conductivity. At the point where the flow regime transition from conduit flow to matrix restricted flow is taking place, the recession becomes distinctively exponential (Fig. 4.1c). This way, the shape of the hydrograph displays a shoulder, too. In sum, a convex hydrograph recession (as displayed on linear axes) can indicate conduit restricted discharge behaviour. If spring discharge at the convex break point is close to the maximum observed discharge, conduit restricted behaviour can be assumed.

\section{Conceptual model Spring hydrograph}

(a) Limited capacity and overflow spring

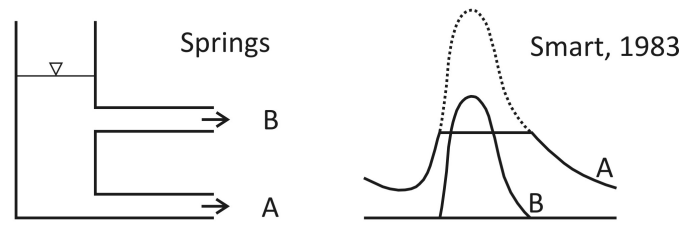

(b) Upgradient reservoir of water

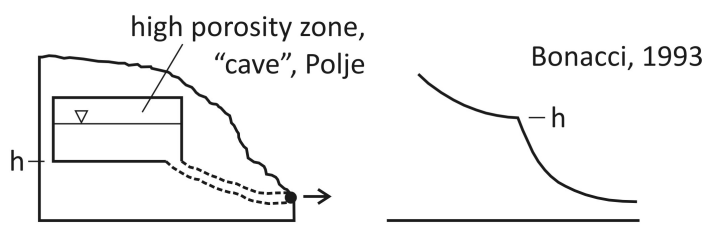

(c) Flow regime transition

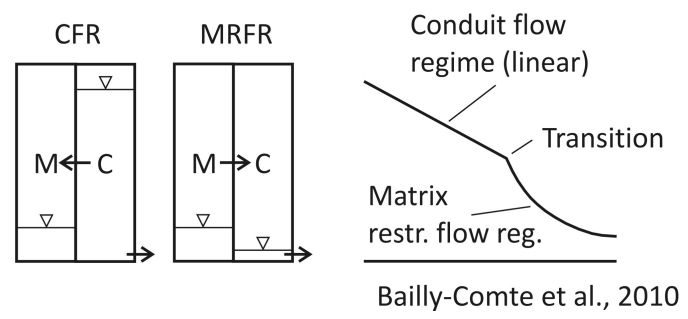

Fig. 4.1: Examples of conceptual models with convex discharge recession behaviour and representative spring hydrographs (displayed with linear axes). Conceptual models modified after Smart (1983), Bonacci (1993), and Bailly-Comte et al. (2010).

The main objective of the study is the characterisation and modelling of conduit restricted karst aquifers. Those aquifers are expected to be challenging regarding the conceptual and mathematical modelling approach. A combination of hydrometric monitoring, hydrogeological data analysis, and minimally parameterised modelling was applied. To obtain unambiguous aquifer parameters, a karst aquifer with low signal convolution (e.g. displaying a sharp recharge input signal and a long recession period) was preferred, which could be expected for semi-arid environments with short and intensive precipitation events and an extended dry season. The approach was executed at the example of Auja spring, the largest fresh water spring in the West Bank (Nuseibeh and Nasser Eddin, 1995). According to the shape of the hydrograph, a pronounced outflow restriction could be assumed. Long-term hydrometric time series were available. In addition, within the context of this study, several high-resolution monitoring stations were installed. 


\subsection{Case study area}

\subsection{General hydrogeologic setting}

The Jordan Valley is part of an endorheic basin with the Dead Sea as terminal lake that developed along the Dead Sea transform (e.g. Garfunkel and Ben-Avraham, 1996). In the southern part of the western margin of the Lower Jordan Valley, eight larger karst springs ( $Q_{\text {mean: }} 0.02-0.3 \mathrm{~m}^{3} \mathrm{~s}^{-1}$ ) emerge from a ca. $800 \mathrm{~m}$ thick Cretaceous carbonate aquifer complex (Fig. 4.2). The springs discharge from its upper sections (Rosenthal and Kronfeld, 1982; Guttman, 2007), constituted by Cenomanian and Turonian dolomite and limestone. Towards the east, the aquifer complex is covered by Coniacian to Maastrichtian sediments, predominantly chalk, which constitute an aquiclude. The lateral boundaries of the spring catchments are unknown. According to stable water isotope data (Kroitoru et al., 1985; isotope data e.g. Gat and Dansgaard, 1972; Ayalon et al., 2004), the recharge area of the springs is located in the highland region along the surface water divide (Fig. 4.2). The divide is located at a topographic elevation of ca. $800 \mathrm{~m}$ ASL, reaching up to $1000 \mathrm{~m}$ ASL. Recharge is predominantly autogenic, because the Coniacian-Maastrichtian cover is only present in the Southeast (Fig. 4.2). The long-term mean recharge fractions for the catchments of individual springs were estimated to be between $25 \%$ and $50 \%$ of the precipitation, based on a chloride mass balance (Schmidt et al., 2013).

\subsubsection{Characteristics of Auja spring}

Auja spring (also sometimes written Uja spring) is located at the banks of an ephemeral stream valley (Wadi Auja, Fig. 4.3). The outflow is located in alluvial sediments, which cover the wadi bottom. Spring water flows in the natural wadi course for about $750 \mathrm{~m}$, after which it is captured and conveyed in a concrete channel to Auja village. Mean spring discharge was about $0.3 \mathrm{~m}^{3} \mathrm{~s}^{-1}$ during the hydrological years 1968-2000 (Palestinian Water Authority, 2000). The most prominent systematic feature of the Auja spring hydrograph is a plateau during discharge maximum. Usually, spring discharge does not exceed ca. $0.5 \mathrm{~m}^{3} \mathrm{~s}^{-1}$.

Auja spring is normally a perennial spring, however, it has been occasionally observed to dry up. For example, dry periods were reported for the consecutive autumn seasons of 1933-1936 (Department of Land Settlement and Water Commissioner, 1947), presumably because of a precedent low precipitation period (data in Rosenan, 1955). During the period of 1967-2000, spring discharge ceased in seven autumn/winter seasons: 1979, 1986, 1987, 1990, 1991, 1999, and 2000 (Palestinian Water Authority data). Also, recent years are characterised by a frequently observed dry-up in summer/autumn. Despite these documented observations, even some months after a considerable flow stopped, water is still observable in the spring tapping structure and abundant green vegetation can be found in the wadi for some hundred meters downstream of the spring. Those observations indicate continued low discharge within the thin wadi alluvial sediments. The response of the spring discharge following intensive precipitation events is rapid. Lag time between the onset of precipitation in the highland area and an increase in spring discharge is less than one day (Schmidt et al., 2012). 


\section{Characterisation and modelling of conduit restricted karst aquifers}
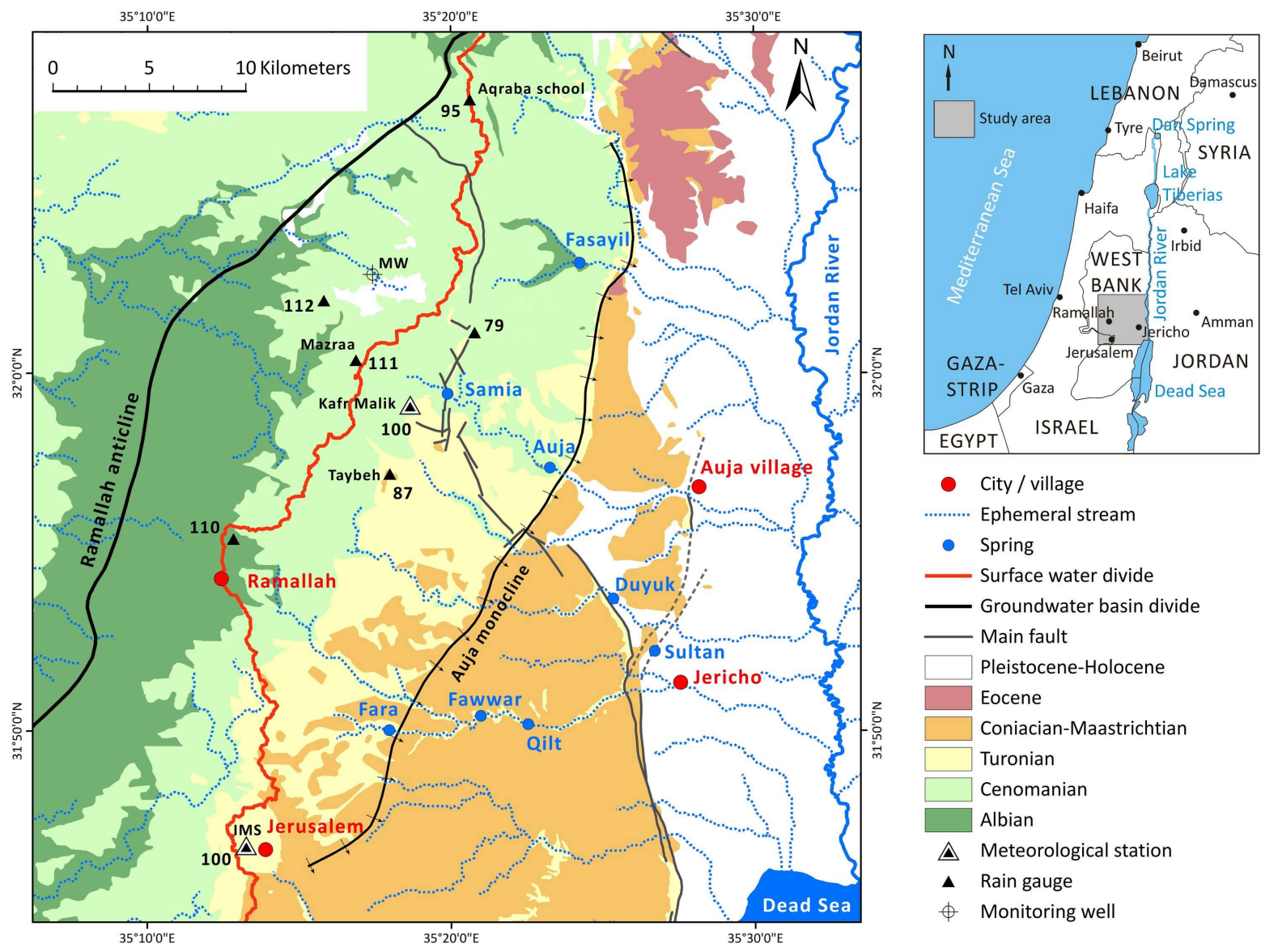

- City / village

.... Ephemeral stream

- Spring

- Surface water divide

Groundwater basin divide

- Main fault

$\square$ Pleistocene-Holocene

Eocene

Coniacian-Maastrichtian

$\square$ Turonian

Cenomanian

Albian

$\triangle$ Meteorological station

$\Delta$ Rain gauge

\$ Monitoring well

Fig. 4.2: Map of the study area displaying the outcrop areas of the geological strata (modified after Schmidt et al., 2013; outcrop areas modified after Sneh et al.,1998; groundwater divide after ANTEA, 1998; Auja monocline after Lenz, 1969). The numbers related to the rain gauges indicate the mean precipitation depth in percent relative to Jerusalem central meteorological station (=100 percent) for different periods of parallel measurements.

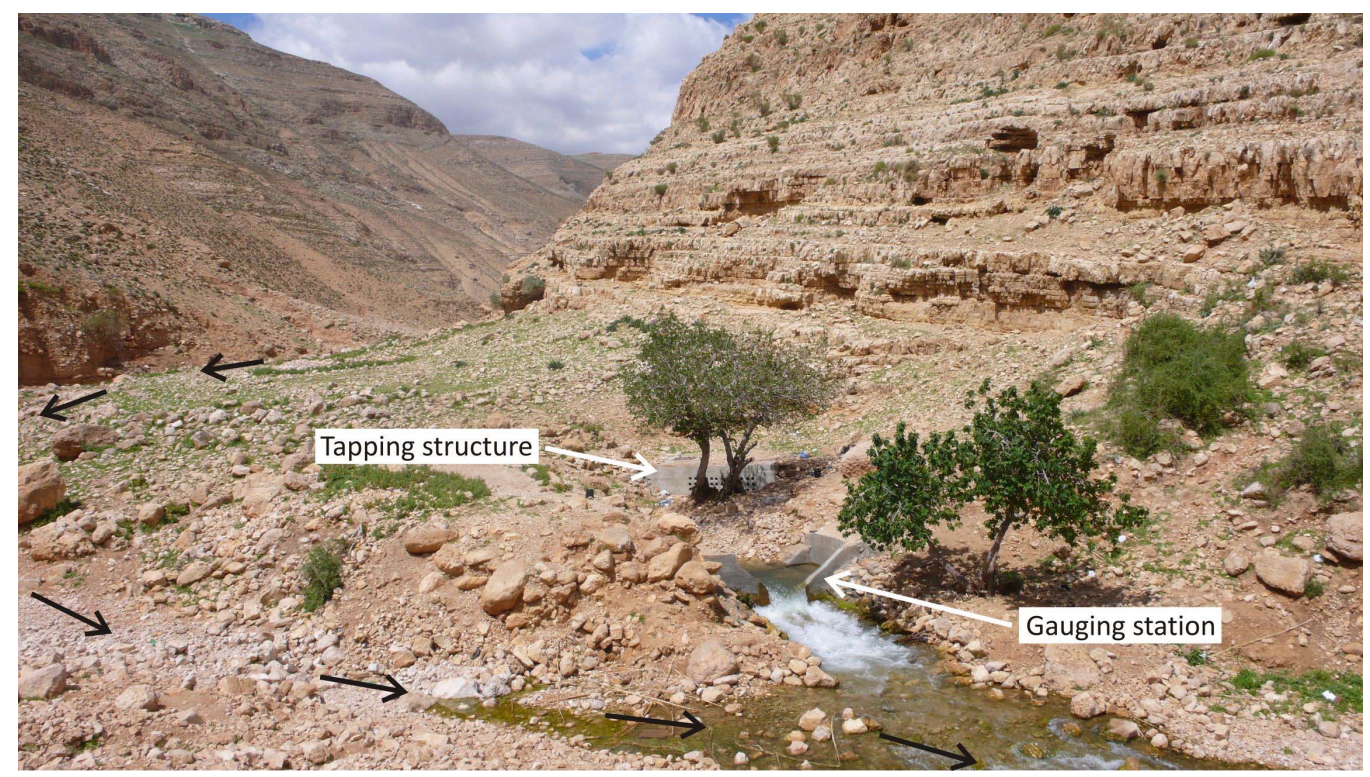

Fig. 4.3: Auja spring in March 2009 (discharge ca. $0.5 \mathrm{~m}^{3} \mathrm{~s}^{-1}$ ). The thalweg of the ephemeral Wadi Auja is indicated by black arrows. In this section, the wadi is incised more than $300 \mathrm{~m}$ into the rather flat paleorelief. The outcropping rock formation in the surroundings of the spring is composed of well bedded dolomicrite of Cenomanian age (Begin, 1975). A buried large diameter tube connects the spring and the gauging station. 


\subsubsection{Karst aquifer development and paleo-base levels in the Lower Jordan Valley region}

Karst aquifer development started in the study area probably during the late Eocene (Frumkin and Fischhendler, 2005). With the subsidence of the Jordan Valley since the late Miocene, the steep incision of the valleys took place (Frumkin and Fischhendler, 2005). During the Pleistocene, the base level in the Dead Sea catchment area was very unstable due to the frequently changing level of the water bodies in the basin (e.g. Waldmann et al., 2009). Kafri and Yechieli (2010) determined paleo-base levels around $-210 \mathrm{~m},-90 \mathrm{~m}$, and $-30 \mathrm{~m}$ ASL by cave mapping in the western rift escarpment. Those levels match the elevation of the springs in the area: Sultan $(-215 \mathrm{~m})$, Duyuk and Fasayil $(-110 \mathrm{~m})$, Auja $(+20 \mathrm{~m})$, and Qilt $(+10 \mathrm{~m})$, which display either a relatively stable discharge or a discharge plateau (data courtesy of the Palestinian Water Authority). Lisker et al. (2009) provided evidence that the level of Lake Lisan ranged in a highstand elevation of $-220 \mathrm{~m}$ to $-190 \mathrm{~m}$ (corresponding to the elevation of the Sultan spring) between $40 \mathrm{ka}$ to $17 \mathrm{ka}$ before present. The two higher horizons are possibly related to paleo-base levels from the Pliocene or early Pleistocene (Kafri and Yechieli, 2010). Here it may be speculated that the Auja spring and other springs are reactivated remnants of those paleo-base levels, which were rapidly undercut by a deeper system. The flow system which adjusted to this base level could have been subsequently blocked by the fine grained sediments of the Lake Lisan (see Kafri and Yechieli, 2010).

It is assumed that the flow restriction is located in the terminal part of the flow system due to the frequent change of base level, resulting in a limited time for carbonate dissolution. Moreover, the dolomite lithology of large parts of the aquifer and frequent thin intercalations of marl and chalk (Begin, 1975) might cause a relatively slow karstification.

\subsection{Data collection and analysis}

\subsection{Spring discharge}

The discharge of Auja spring was measured at monthly intervals during the hydrological years of 1968-2000 by the West Bank Water Department (Palestinian Water Authority, 2000). Measurements, e.g. by current meter, were conducted in the concrete channel conveying the spring water to Auja village (personal communication, M. Nuseibeh). These time series cover the broad range of hydrological conditions characteristic for the semi-arid environment. Additionally, a permanent V-notch weir was constructed in 2008 directly at the spring, to interpret discharge dynamics with a high accuracy and a high temporal resolution (Fig. 4.3; Schmidt et al., 2012). A rating curve was established by a number of discharge measurements (salt dilution method) covering the whole range of flow conditions. Stage was automatically recorded every 5-15 minutes (measurement devices: MPS-D and Dipper-TEC, SEBA Hydrometrie Gmbh; MicroDiver, Schlumberger Water Services). The measurements of stage are influenced by recreational activities at the spring (e.g. bathing in the approach channel) and need to be corrected manually before discharge can be computed. The processed discharge hydrograph is displayed in Fig. 4.4. 


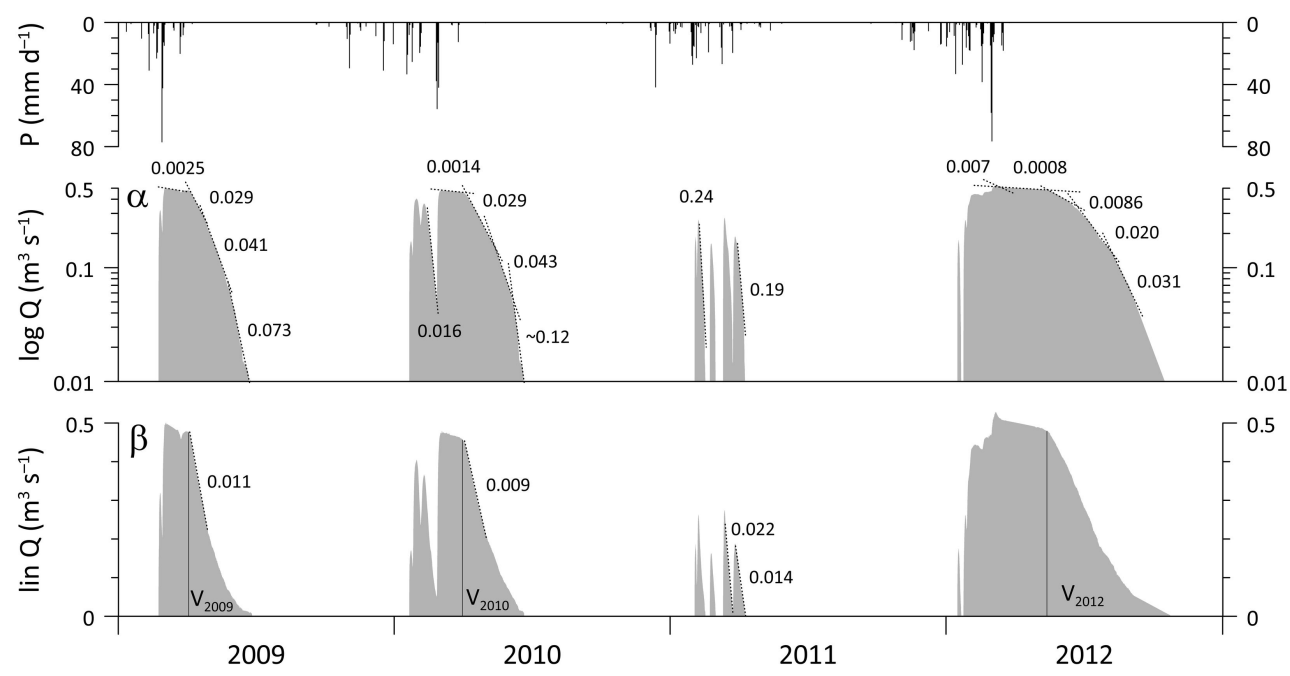

Fig. 4.4: High resolution hydrograph of Auja spring during 2009-2012, displaying the convex upward recession behaviour. Examples for different recession coefficients $\alpha$ (in units of $\mathrm{d}^{-1}$ ) and $\beta$ (in units of $\mathrm{m}^{3} \mathrm{~s}^{-1} \mathrm{~d}^{-1}$ ) are highlighted (see Section 4.3.2). The last six weeks of the 2012 flow period, the hydrograph is linearly interpolated between two discrete discharge measurements. Precipitation data measured at meteorological station Kafr Malik.

\subsubsection{Recession and event analysis of the Auja spring hydrograph}

Recent continuously recorded discharge and long-term point data of 1967-2000 provide the basis for a recession analysis using Maillet (1905): $Q_{t}=Q_{0} e^{-\alpha t}$, with $Q_{0}$ the discharge at the start of recession segment $\left(\mathrm{m}^{3} \mathrm{~s}^{-1}\right)$ and $Q_{t}$ the discharge at time $t(\mathrm{~d})$. Recession coefficients of the longterm data were evaluated by analysing the parts of the hydrograph between the last major precipitation event of the preceding winter season and the first larger event of the succeeding season to avoid the influence of recharge events on the recession hydrograph. The hydrographs were checked for extended straight-line segments (length usually 2-6 months). The histogram of the data displayed distinct clusters and the data were grouped accordingly (Table 4.1). The high temporal resolution of the newly obtained hydrograph permitted a detailed determination of recession coefficients (Fig. 4.4 and Table 4.2).

Table 4.1: Characteristic recession coefficients derived from the analysis of the long-term monitoring data 19672000. A few higher $\alpha$-values such as 0.05 or 0.07 were recognised as well.

\begin{tabular}{lcccc}
\hline $\begin{array}{l}\text { Recession } \\
\text { characteristics }\end{array}$ & $\begin{array}{c}\alpha \text { median } \\
\left(\mathrm{d}^{-1}\right)\end{array}$ & $\begin{array}{c}\alpha \text { mean } \\
\left(\mathrm{d}^{-1}\right)\end{array}$ & $\begin{array}{c}\alpha \text { range } \\
\left(\mathrm{d}^{-1}\right)\end{array}$ & sample $n$ \\
\hline plateau & 0.00092 & 0.00096 & $0.0005-0.0021$ & 11 \\
slow & 0.0040 & 0.0039 & $0.0022-0.0052$ & 13 \\
medium & 0.0081 & 0.0080 & $0.0068-0.0098$ & 15 \\
medium-fast & 0.0111 & 0.0118 & $0.0101-0.0153$ & 6 \\
fast & 0.0199 & 0.0201 & $0.0183-0.0218$ & 5 \\
very fast & 0.0353 & 0.0353 & $0.0349-0.0357$ & 5 \\
\hline
\end{tabular}

Above a flow threshold at ca. $0.47 \mathrm{~m}^{3} \mathrm{~s}^{-1}$ (range: $0.46-0.48 \mathrm{~m}^{3} \mathrm{~s}^{-1}$, period 2009-2012), a slightly inclined discharge plateau was observed. For the plateau time period, recession displayed a median value of $0.0009 \mathrm{~d}^{-1}$ (Table 4.1). After the large recharge event of February/March 2012, an initial peak at $0.53 \mathrm{~m}^{3} \mathrm{~s}^{-1}$ superimposed on the plateau was observed, displaying a comparatively 
rapid recession coefficient of about $0.007 \mathrm{~d}^{-1}$ (Figs. 4.4 and 4.5). Discharge returned to the plateau value (at this time about $0.51 \mathrm{~m}^{3} \mathrm{~s}^{-1}$ ) within seven days after the peak. Below the threshold, different recession coefficients were often derived for individual years (Table 4.1). The various recession coefficients are attributed to a variable hydraulic head and stored groundwater volume in different aquifer compartments. Conceptually, two reservoirs are postulated: a highly permeable reservoir, comprising the conduit system and other highly permeable features (fractures, karst voids, caves, etc.) and a low permeability reservoir, comprising a rock matrix with smallscale fractures. Figure 4.5 displays sketches for the different recession behaviour observed. During years with a presumably high fill level of the low permeability reservoir (LPR), recession below the threshold was rather slow as well (scenario 1). A prominent baseflow recession coefficient derived is $0.004 \mathrm{~d}^{-1}$, estimated to be representative for the drainage of the LPR. In many years, a recession coefficient of about $0.008 \mathrm{~d}^{-1}$ was observed instead, at least for the early part of the post-plateau recession (scenario 2). During discharge conditions, when the LPR can be assumed as largely depleted, the recession coefficients are even higher during the early parts of the recession, with 0.011 and $0.020 \mathrm{~d}^{-1}$ being typical values. This period was again followed by periods of intermediate coefficients of ca. $0.008-0.011 \mathrm{~d}^{-1}$ (scenario 3). During periods when the LPR is almost completely drained, the recession even retained the convex shape over the whole period, viz. recession coefficients increased with time. A typical sequence is 0.02-0.0350.05/0.07 $\mathrm{d}^{-1}$ until the spring "stops" flowing (scenario 4).

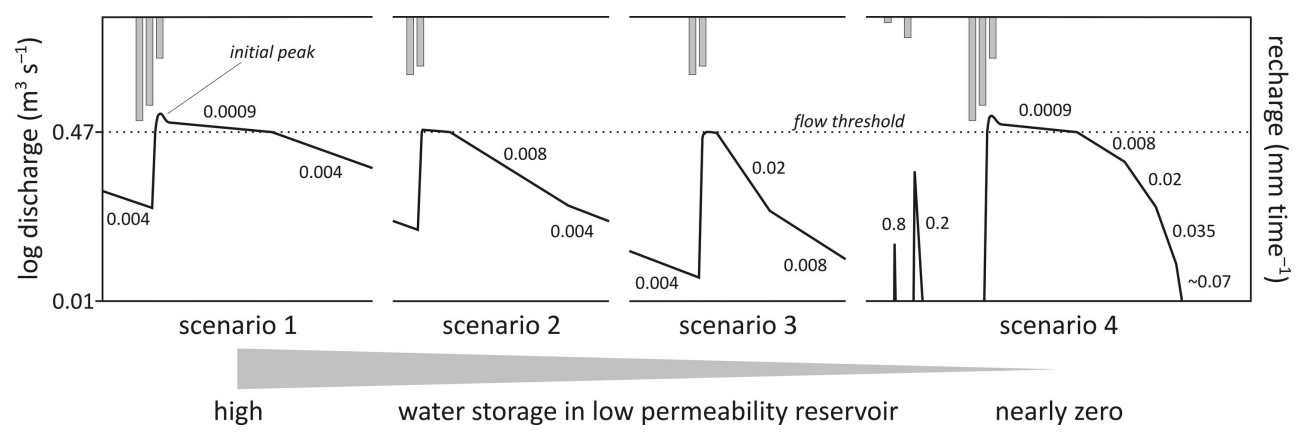

Fig. 4.5: Schematics of the complex recession behaviour of the Auja spring flow system according to the water storage in the assumed low permeability reservoir.

During the 2009-2012 discharge monitoring, a period of presumably very low matrix storage prevailed. Because no baseflow was measured at the onset of each individual winter flood, single recharge events often led to individual spring flow periods. Those events were analysed for discharge quantity and recession behaviour, in order to assess event groundwater recharge and system properties (Table 4.2). For small to medium events-the flow threshold at $0.47 \mathrm{~m}^{3} \mathrm{~s}^{-1}$ was not reached-event recession was usually very rapid (Fig. 4.4; Table 4.2). For certain events, the falling limb of the hydrograph even took a linear form (as displayed with linear axes; Figs. 4.1c and $4.4 \beta$ ), indicating that only the conduit reservoir was active. Therefore, it can be expected that conduit properties can be estimated from the data. For small to medium recharge events, a highly non-linear correlation of $\alpha$ with event discharge could be observed (Fig. 4.6). For most small events, the recession coefficient ranged at ca. $0.2 \mathrm{~d}^{-1}$. For two low discharge events, coefficients of 0.7 and $0.9 \mathrm{~d}^{-1}$ were evaluated. Since linear recession periods are not well described by semilogarithmic coefficients, those recession periods were further analysed for coefficient $\beta\left(\mathrm{m}^{3} \mathrm{~s}^{-1} \mathrm{~d}^{-1}\right)$ according to Bailly-Comte et al. (2010): $Q_{t}=Q_{0}-\beta^{*} t$ (Table 4.2, Fig. 4.4). 


\section{Characterisation and modelling of conduit restricted karst aquifers}

Table 4.2: Recharge event and recession analysis of the high resolution monitoring data 2009-2012 for individual storms. Hydrograph recessions for small to medium events were occasionally linear. Therefore, more than one recession coefficient $\alpha$ is displayed with a logarithmic $y$-axis.

\section{Small to medium events}

\begin{tabular}{|c|c|c|c|c|c|c|}
\hline No. & $\begin{array}{c}\text { Date of } \\
\text { precipitation }\end{array}$ & $\begin{array}{l}\text { P event } \\
(\mathrm{mm})^{\mathrm{a}}\end{array}$ & $\begin{array}{c}Q \text { peak } \\
\left(1 \mathrm{~s}^{-1}\right)\end{array}$ & $\begin{array}{c}Q \text { event } \\
\left(\mathrm{m}^{3}\right)^{\mathrm{b}}\end{array}$ & $\begin{array}{c}\alpha \\
\left(\mathrm{d}^{-1}\right)\end{array}$ & $\begin{array}{c}\beta \\
\left(\mathrm{m}^{3} \mathrm{~s}^{-1} \mathrm{~d}^{-1}\right)\end{array}$ \\
\hline 2009 & 20-22. Feb & 48 & 320 & $180.000^{*}$ & 0.22 & \\
\hline $2010-1$ & 17-18. Jan & 53 & 170 & $110.000^{*}$ & 0.19 & \\
\hline $2010-2$ & 24-25. Jan & 27 & 405 & $380.000^{*}$ & 0.15 & \\
\hline $2010-3$ & 03-05. Feb & 42 & 370 & $290.000^{*}$ & 0.16 & \\
\hline 2011-1 & 30. Jan-02. Feb & 76 & 190 & $40.000^{*}$ & 0.68 & \\
\hline 2011-2 & 04-05. Feb & 25 & 260 & $120.000^{*}$ & 0.24 & \\
\hline $2011-3$ & 20-21. Feb & 22 & 160 & 70.000 & $0.22 / 0.64$ & 0.027 \\
\hline 2011-4 & 09-11. Mar & 40 & 270 & 160.000 & $0.17 / 0.26 / 0.43$ & 0.022 \\
\hline $2011-5$ & 24. Mar & 29 & 190 & 140.000 & $0.075 / 0.19 / 0.26$ & 0.014 \\
\hline 2012 & 13-14. Jan & 29 & 175 & 50.000 & 0.89 & \\
\hline
\end{tabular}

Large events

\begin{tabular}{ccccccc}
\hline No. & $\begin{array}{c}\text { Date of } \\
\text { precipitation }\end{array}$ & $\begin{array}{c}P \text { event } \\
(\mathrm{mm})^{\mathrm{a}}\end{array}$ & $\begin{array}{c}Q \text { peak } \\
\left(\mathrm{l} \mathrm{s}^{-1}\right)\end{array}$ & $\begin{array}{c}Q \text { event } \\
\left(\mathrm{m}^{3}\right)^{\mathrm{b}}\end{array}$ & $\begin{array}{c}\alpha \text { plateau } \\
\left(\mathrm{d}^{-1}\right)\end{array}$ & $\begin{array}{c}\alpha \text { post-plateau section } \\
\left(\mathrm{d}^{-1}\right)\end{array}$ \\
\hline 2009 & 27. Feb-03. Mar & 129 & 500 & not separable & 0.0025 & $0.029 / 0.041 / 0.073$ \\
2010 & 25. Feb-01. Mar & 147 & 480 & $2.600 .000^{*}$ & 0.0014 & $0.029 / 0.043 / 0.120$ \\
2012 & 28. Feb-04. Mar & 163 & 530 & not separable & 0.0008 & $0.0086 / 0.020 / 0.031$ \\
\hline
\end{tabular}

a Mean of the three precipitation gauging stations Kafr Malik, Taybeh, and Mazra'a ash-Sharqiya, located in the highland area.

b Integrated discharge due to precipitation/recharge event. In case of composite events, at the hydrograph minimum between events, the recession limb of the first event was reconstructed. The calculated recession discharge value was added to the first event and subtracted from the subsequent event. Values are marked with an asterisk $\left(^{*}\right)$.

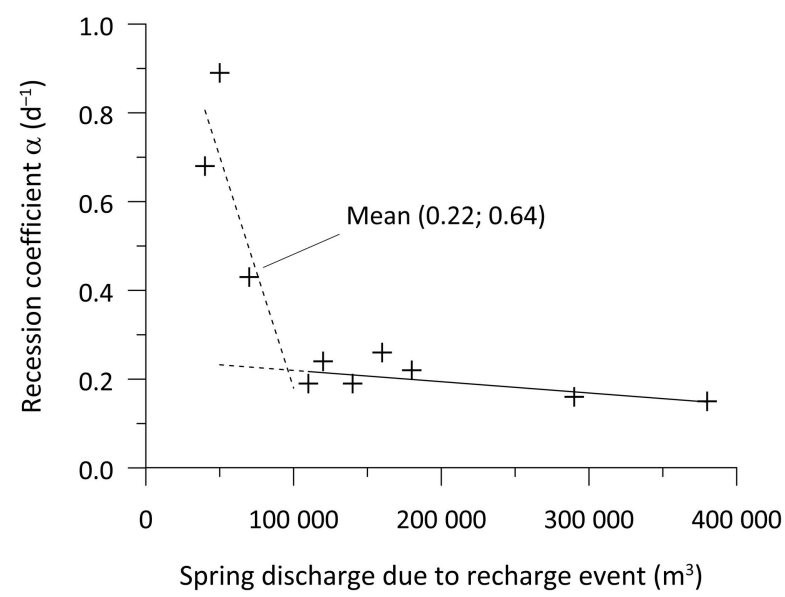

Fig. 4.6: Relationship between recession coefficient $\alpha$ and the amount of water discharged for the small to medium recharge events (Table 4.2). For linear recession events, either the middle or mean $\alpha$ value was used. The number of event data with a very high $\alpha$ is still insufficient to derive a sound correlation, however, the intersection (the point of nonlinearity) is assumed to be located between 50 000-100 $000 \mathrm{~m}^{3}$ of event discharge. 
In sum, during the detailed monitoring period of 2009-2012, the observed range of recession coefficients $\alpha$ covered three orders of magnitude (0.0008-0.9 $\left.\mathrm{d}^{-1}\right)$. The recession coefficients derived from the high-resolution data (especially those for the rainy winter season of 2011/2012) were in a good agreement with the coefficients derived for the long-term monitoring data, despite the different gauging methods and locations. As similar values were obtained for the flow threshold, the long-term data can be assumed to be largely correct.

\subsubsection{Flow and recharge dynamics of the Auja spring system}

A monitoring well in an unconfined aquifer (same hydrostratigraphic unit as Auja spring outlet) is located northwest of Auja spring (Fig. 4.2). A low local hydraulic conductivity of ca. $1^{*} 10^{-6} \mathrm{~m}$ $\mathrm{s}^{-1}$ was calculated from pumping test recovery data (Mekorot internal files). Therefore, the hydrograph is indicative of the hydraulic behaviour of the low permeability fractured rock matrix. However, due to unknown aquifer boundaries, it is not certain if the well is located in the catchment of Auja spring. Groundwater head records were available for the period of 1983-1991 (Fig. 4.7) displaying two long-term periods with extended increasing groundwater potentials and recession limbs. During the same period, the spring hydrograph displayed a recession behaviour covering several years, with superimposed peaks for individual winter seasons. The discharge amounts attributed to the individual winter seasons were graphically separated and are assumed to approximate the seasonal total recharge in the catchment area (Fig. 4.7). For the analysed nine hydrological years, more than half of the total discharge of about 70 million $\mathrm{m}^{3}$ was estimated to be recharged during the two wet winter seasons of 1982/1983 and 1987/1988. These two winter seasons caused a substantial rise in the groundwater level observed in the monitoring well.

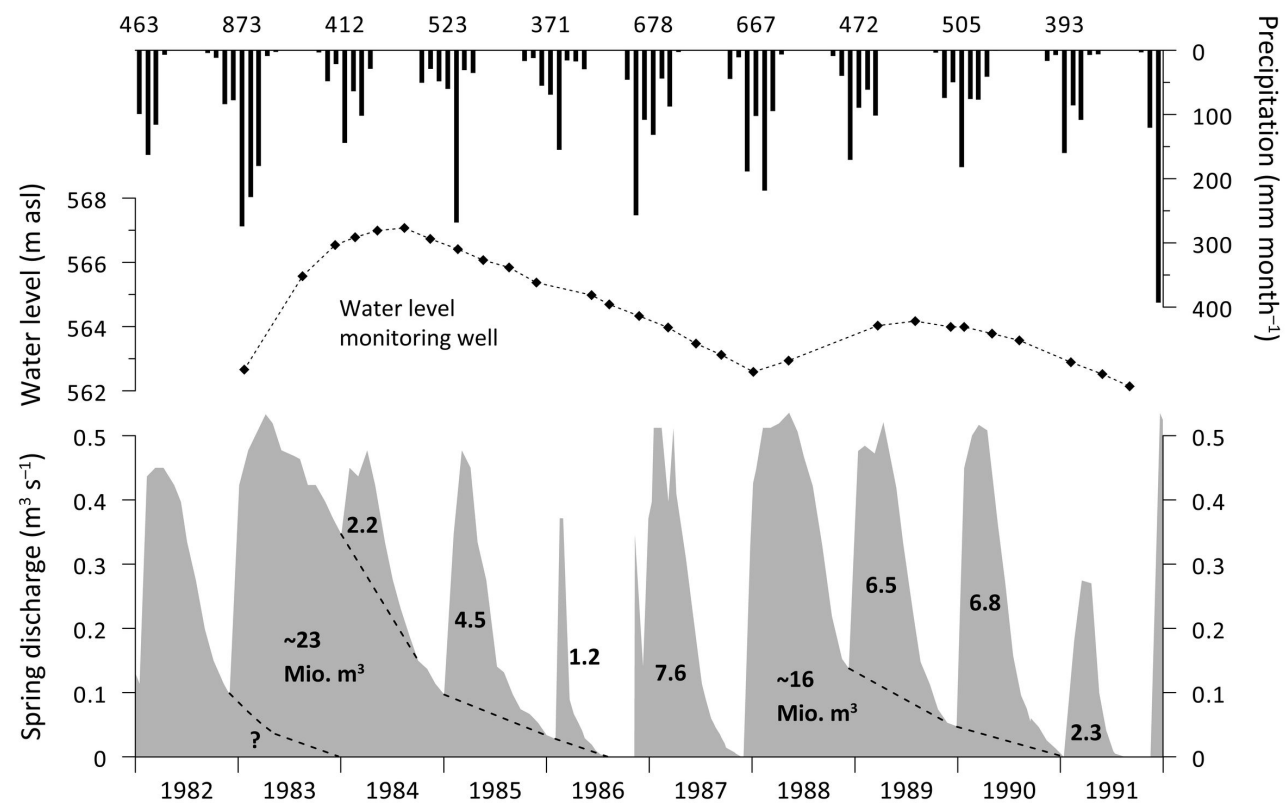

Fig. 4.7: Hydrographs of Auja spring discharge and water level in a monitoring well, together with the monthly and yearly precipitation sums for Jerusalem. Note the 1.5 year time lag between precipitation and maximum groundwater level (discharge data: Palestinian Water Authority, Ramallah; water level data: MEKOROT, Tel Aviv). 


\subsubsection{Meteorological data and calculation of potential evapotranspiration}

Jerusalem central meteorological station (Israel Meteorological Service, $800 \mathrm{~m} \mathrm{ASL}$ ) is regarded as the reference station for the region (ANTEA, 1998), because of a continuous daily precipitation record starting in 1950 (European Climate Assessment and Dataset, http://eca.knmi.nl; Klein Tank et al., 2002). The Aqraba gauging station is located at the surface water divide ca. $40 \mathrm{~km}$ north of Jerusalem (Fig. 4.2) and exhibited a relatively complete monthly precipitation time series for the period of 1963-1997 (SMART project database, http://www.ufz.de/daisy/). The monthly precipitation record shows good correlation with the Jerusalem data (ANTEA, 1998 and own calculations), however some data gaps are observed. Within this study, several automatically logging rain gauges (RG3-M, Onset Computer Corporation) were installed around the surface water divide (Fig. 4.2). The stations represented ca. $80-110 \%$ of the relative precipitation depth observed at Jerusalem station during the measurement period.

For the calculation of potential evapotranspiration ETp, the Hargreaves-equation (Hargreaves and Samani, 1985) was selected. It was developed for the Davis lysimeter station in California (Hargreaves and Allen, 2003), a location with comparable Mediterranean semi-arid climatic characteristics (i.e. mean temperature, mean annual precipitation depth, precipitation distribution during the course of the year). Its suitability for the calculation of ETp, especially in semiarid climates, was verified by Jensen et al. (1997), Droogers and Allen (2002), and Weiß and Menzel (2008). In the study of Weiß and Menzel (2008), the Hargreaves-equation calculations were in exact accordance with corrected pan evaporation data for the central part of the West Bank. ETp is calculated by the equation:

$\operatorname{ETp}=0.0023 * \mathrm{Ra}^{*}\left(T_{\text {mean }}+17.8\right) *\left(T_{\max }-T_{\min }\right)^{0.5 *} \lambda^{-1}$

where $\mathrm{Ra}$ is extraterrestrial solar radiation $\left(\mathrm{MJ} \mathrm{d}^{-1}\right)$, calculated on a daily time step by equations cited in Allen et al. (1998), $T_{\text {mean }}$ is the mean air temperature during the respective time interval (average of daily minimum and maximum temperature, ${ }^{\circ} \mathrm{C}$ ), $T_{\max }-T_{\min }$ is the daily temperature range, and $\lambda$ is the latent heat of vaporisation in order to obtain ETp in units of $\mathrm{mm} \mathrm{d}^{-1}$. Jerusalem central meteorological station was also the long-term reference station for the air temperature data for this study. The available time series covered the period of 1964-2010 (European Climate Assessment and Dataset). Within this study, an automatic meteorological station (H21-001, Onset Computer Corporation) was installed in Kafr Malik in the highland region. Air temperature was measured during the period of 2008-2012 with a time resolution of 5-10 minutes. From this data, daily maximum and minimum air temperatures were derived. The correlation with the Jerusalem data was very good (linear regression between parallel measurements; $R^{2} T \min =0.97, R^{2} T \max =0.99$ ). Because of its higher elevation, Kafr Malik station displayed on average a $0.7{ }^{\circ} \mathrm{C}$ lower air temperature.

\subsection{Reservoir model}

As a main tool for the quantitative analysis of the system, a conduit restricted reservoir model was developed. The model needed to simulate the long-term recession and simultaneously the 
observed fast discharge response, the plateau in discharge, and the water budget. The aim was to employ the least possible number of calibration parameters, in order to keep ambiguity low (e.g. Kirchner, 2006). A further aim was to develop a modelling concept that could be generalised and transferred to other karst groundwater systems. The model is based on the conservation of fluid mass and is split into two sub-modules, a soil/epikarst module SEM and an aquifer module AM. Both modules operate at a daily time step $\left(t_{1}-t_{0}=1 \mathrm{~d}\right)$, assuming instant head equilibrium within the reservoirs. The SEM provides the input to the AM by deep percolation (Fig. 4.8). Deep percolation is regarded as groundwater recharge at the arrival of water at the water table. Because of the fast spring response to recharge events, a negligible time lag is assumed in this modelling study.

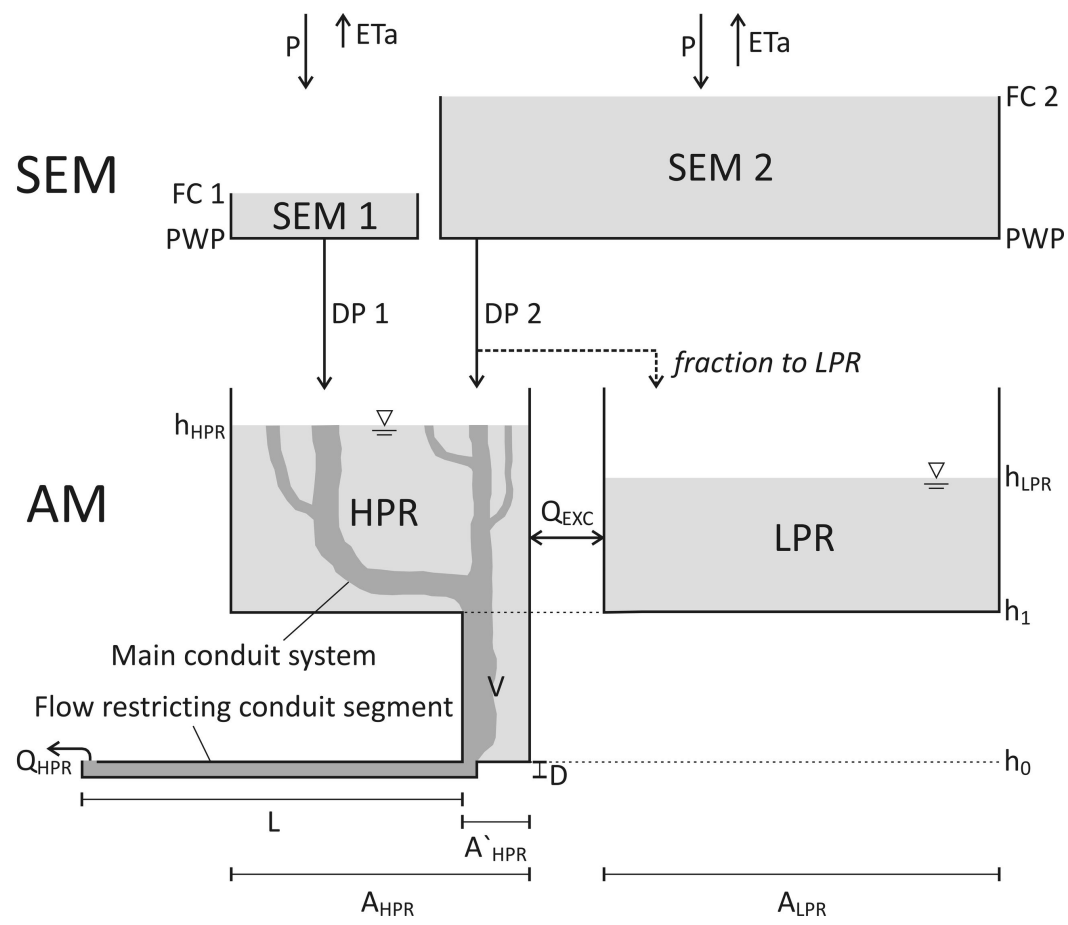

Fig. 4.8: Schematic representation of the reservoir model. The various parameters are specified in the text and in Table 4.3.

\subsection{Soil/Epikarst Module (SEM)}

The SEM consists of a soil water balance model (Sauter, 1992; Rushton et al., 2006; Geyer, 2008) with precipitation $P$ as the input parameter for the soil moisture storage SMS, which is varied between the permanent wilting point PWP and field capacity FC (all values in mm). To simplify the approach, soil moisture storage at the PWP is set to zero. Output is by actual evapotranspiration ETa and by deep percolation DP, once the soil moisture storage exceeds field capacity:

$$
\begin{array}{ll}
\mathrm{SMS}_{t 1}=\mathrm{SMS}_{t 0}+P_{t 1}-\mathrm{ETa}_{t 1}-\mathrm{DP}_{t 1} & \text { with } \\
\mathrm{DP}_{t 1}=\mathrm{SMS}_{t 0}+P_{t 1}-\mathrm{ETa} t 1-\mathrm{FC} & \text { if }\left(\mathrm{SMS}_{t 0}+P_{t 1}-\mathrm{ETa}_{t 1}\right)>\mathrm{FC}
\end{array}
$$

In hydrological models, ETa is often derived from ETp as a function of the relative water saturation in the soil store (e.g. Perrin et al., 2003; Hartmann et al., 2012a). In this study, a different approach is applied based on two considerations: (1) In the highland part of the study area, the 
predominant vegetation type is grass-/shrubland sustained by winter precipitation. Ryu et al. (2008) measured the ETa of a semi-arid grassland site with very comparable climatic characteristics (located close to the Davis lysimeter station; Section 4.3.4). They showed that for most of the winter months with considerable precipitation, ETa nearly equaled ETp ("energy-limited period"). During the spring months, usually starting from April or May, ETa became considerably lower than ETp, because of the low precipitation amounts but already high ETp (start of "water-limited period"). (2) Rushton et al. (2006) argue that especially fine grained soils retain a part of the infiltrated water temporally near the surface ("near surface soil storage") and hence provide local nearly saturated conditions, enabling ET at the potential rate. The soils in the study area are of silt loam texture and near surface soil storage was observed (Hanf, 2010). For those reasons, ETa is set equal to ETp until the wilting point is reached:

$$
\mathrm{ETa}_{t 1}= \begin{cases}\mathrm{ETp}_{t 1} & \text { if }\left(\mathrm{SMS}_{t 0}+P_{t 1}\right) \geq \mathrm{ETp}_{t 1} \\ \mathrm{SMS}_{t 0}+P_{t 1} & \text { if }\left(\mathrm{SMS}_{t 0}+P_{t 1}\right)<\mathrm{ETp}_{t 1}\end{cases}
$$

It is apparent from the spring hydrograph that groundwater recharge occurs in all monitored years, even during winters with very low precipitation depth (e.g. 1998/1999). These observations cannot be reproduced by assuming a uniform field capacity across the entire area, as usually applied in karst reservoir models (e.g. Rimmer and Salingar, 2006; Fleury et al., 2007; Hartmann et al., 2012a). A spatially variable soil thickness and epikarst storage capacity is frequently observed in karst systems (e.g. Williams, 1983; Arbel et al., 2010). Consequently, Hartmann et al., (2012b) used a soil/epikarst graduation consisting of 15 cells. In this study, the catchment area $A$ was divided into two SEMs with different field capacities (SEM 1 with FC 1 and SEM 2 with FC 2) to account for soil/epikarst variability with a moderate number of parameters:

$A$ sem $1=x * A$ with $0<x<1$ and $A$ sem $2=(1-x) * A$

with $x$ as the fraction of SEM 1 of the total catchment area $A$. This way, deep percolation and subsequent groundwater recharge is enabled for a part of the study area at lower precipitation totals.

\subsubsection{Aquifer Module (AM)}

The aquifer module consists of a highly permeable reservoir HPR and a low permeability reservoir LPR (Fig. 4.8). System outflow occurs exclusively from the HPR via spring discharge $Q$ HPR. The aquifer module base areas ( $A_{n}$ for reservoir $n$ ) are intended to display the effective porosity $n_{\text {eff, }}$ of the respective aquifer compartment: $A_{n}=A^{*} n_{\text {eff }}$ (Fiorillo, 2011). This way, as the base areas are calibration parameters, an estimate of $n_{\text {eff }}$ for the different aquifer porosity compartments is derived from the calibrated model. For example, in case of a spring catchment area of $1 \mathrm{~km}^{2}$ and a calibrated matrix reservoir base area of $10000 \mathrm{~m}^{2}$, an effective matrix porosity of $1 \%$ would be derived. The deep percolation calculated by the SEM is converted from $\mathrm{mm} \mathrm{d}^{-1}$ to $\mathrm{m}^{3} \mathrm{~d}^{-1}$ according to the respective SEM size. A lateral flow concentration of infiltrated water towards preferential percolation pathways (shafts, main fractures) can be generally assumed for epikarst zones (Williams, 1983). Hence, in this model, all deep percolation is added to the HPR, which is assumed to be connected to the main points of recharge, such as the ephemeral surface 
drainage network and preferential flow paths from the epikarst zone and soil pockets. The water volume stored in the HPR is calculated by the following equation:

$V_{\mathrm{HPR}, t 1}=V_{\mathrm{HPR}, t 0}+\mathrm{DP} 1_{t 1}+\mathrm{DP} 2_{t 1}+\mathrm{QEXC}, t 0_{-} \mathrm{QHPR}, t 0$

with $Q$ Exc being the water exchange between both reservoirs depending on the head difference multiplied by a lumped exchange parameter LEP $\left(\mathrm{m}^{2} \mathrm{~d}^{-1}\right)$ (Bauer et al., 2003; De Rooij, 2008):

$Q_{\mathrm{EXC}}=\mathrm{LEP} * \begin{cases}h_{\mathrm{LPR}}-h_{\mathrm{HPR}} & \text { if }\left(h_{\mathrm{HPR}}>h_{1}\right) \\ h_{\mathrm{LPR}}-h_{1} & \text { if }\left(h_{\mathrm{HPR}}<h_{1}\right)\end{cases}$

The LEP is the product of the interfacial area between both reservoirs AExc $\left(\mathrm{m}^{2}\right)$ and an exchange coefficient $\alpha\left(\mathrm{d}^{-1}\right)$ :

$\mathrm{LEP}=A \mathrm{EXC}{ }^{*} \alpha$

Table 4.3: Parameters used for the setup and calibration of the reservoir model. Calibration parameters marked in bold typeface.

\begin{tabular}{|c|c|c|c|c|}
\hline \multicolumn{2}{|c|}{ Parameter } & Value & Unit & Source/calculation method \\
\hline \multicolumn{5}{|c|}{ Soil-Epikarst Module (SEM) } \\
\hline$R$ & Long-term mean recharge fraction of $P$ & 0.34 & - & Estimated (Schmidt et al., 2013) \\
\hline$A$ & Catchment recharge area size & 49 & $\mathrm{~km}^{2}$ & Calculated (water and $\mathrm{Cl}^{-}$mass balance) \\
\hline$P$ & Daily precipitation & & $\mathrm{mm}$ & Measured \\
\hline ETp & Daily potential evapotranspiration & & $\mathrm{mm}$ & Calculated (Hargreaves equation) \\
\hline ETa & Daily actual evapotranspiration & & $\mathrm{mm}$ & Calculated (soil water balance) \\
\hline PWP & Permanent wilting point & 0 & $\mathrm{~mm}$ & Set (for purpose of clarity) \\
\hline FC 1 & Field capacity of SEM 1 & 70 & mm & Calibrated \\
\hline FC 2 & Field capacity of SEM 2 & 190 & mm & Calibrated \\
\hline$x$ & SEM 1 area relative to total catchment area $A$ & 0.28 & - & Estimated (event analysis) \\
\hline DP 1 & Deep percolation from SEM 1 & & $\mathrm{~m}^{3}$ & Calculated (soil water balance) \\
\hline DP 2 & Deep percolation from SEM 2 & & $\mathrm{~m}^{3}$ & Calculated (soil water balance) \\
\hline \multicolumn{5}{|c|}{ Aquifer Module (AM) } \\
\hline$h_{0}$ & Conduit outflow level & 0 & $\mathrm{~m}$ & Set (for purpose of clarity) \\
\hline$h_{\mathrm{HPR}}$ & Head in HPR & & $\mathrm{m}$ & Calculated \\
\hline$h_{\text {LPR }}$ & Head in LPR & & $\mathrm{m}$ & Calculated \\
\hline$h_{1}$ & Head in HPR at flow threshold & 100 & m & Joint calibration to match a discharge of \\
\hline$L$ & Length of restricting conduit & 10,000 & $\mathrm{~m}$ & $0.47 \mathrm{~m}^{3} \mathrm{~s}^{-1}$ (discharge at the flow \\
\hline$D$ & Diameter of restricting conduit & 0.8 & $\mathrm{~m}$ & threshold); head sensitive, conduit \\
\hline$\varepsilon$ & Surface roughness of restricting conduit & 0.196 & $\mathrm{~m}$ & parameters insensitive \\
\hline$V$ & Volume of lower part of HPR & $1,200,000$ & $\mathrm{~m}^{3}$ & estimated (recession \& event analysis) \\
\hline$A_{\text {HPR }}^{\prime}$ & Base area of lower part of HPR & 12,000 & $\mathrm{~m}^{2}$ & Calculated from $V$ and $h_{1}$ \\
\hline Aнгк & Base area of higher part of HPR & 200,000 & $\mathbf{m}^{2}$ & Calibrated \\
\hline Alpr & Base area of LPR & $1,000,000$ & $\mathbf{m}^{2}$ & Calibrated \\
\hline LEP & Lumped exchange parameter LPR-HPR & 3500 & $\mathbf{m}^{2} \mathrm{~d}^{-1}$ & Calibrated \\
\hline$\alpha$ & Exchange coefficient & 0.004 & $\mathrm{~d}^{-1}$ & Estimated (recession analysis) \\
\hline A Exc & Interface area between LPR and HPR & $\sim 900,000$ & $\mathrm{~m}^{2}$ & Calculated from LEP and $\alpha$ \\
\hline QHPR & Spring discharge & & $\mathrm{m}^{3} \mathrm{~s}^{-1}$ & Measured / calculated \\
\hline
\end{tabular}

Based on Section 4.2.3, the flow restriction for the HPR is assumed to be located in the terminal part of the main conduit system, which connects the recharge area with the current discharge point. It is conceptualised as a conduit with low discharge capacity. Similar approaches were used e.g. by Smart (1983), Halihan et al. (1998), and Covington et al. (2009). The flow restricting 
pipe is assumed to be always fully saturated. Theoretical considerations regarding the expected pipe diameter and the flow velocity indicate that flow will be always turbulent. Turbulent flow in fully saturated pipes can be calculated by the Darcy-Weisbach and Colebrook-White laws (e.g. Liedl et al., 2003; Reimann et al., 2014):

$$
Q_{\mathrm{HPR}}=-2 Y \log \left(\frac{2.51 \pi \nu D}{4 Y}+\frac{\varepsilon}{3.71 D}\right) \quad \text { with } \quad Y=\sqrt{\frac{h_{\mathrm{HPR}} g D^{5} \pi^{2}}{8 L}}
$$

Where $v$ is the kinematic viscosity of water $\left(\mathrm{m}^{2} \mathrm{~s}^{-1}\right), D$ the conduit diameter $(\mathrm{m}), \varepsilon$ the conduit surface roughness $(\mathrm{m}), g$ the gravitational acceleration $\left(\mathrm{m} \mathrm{s}^{-2}\right)$, and $L$ the conduit length $(\mathrm{m})$. Discharge is driven by the head difference between the conduit outlet and the head in the HPR:

$h_{\mathrm{HPR}}= \begin{cases}V_{\mathrm{HPR}} / A_{\mathrm{HPR}} & \text { if }\left(V_{\mathrm{HPR}} \leq V\right) \\ \left(V_{\mathrm{HPR}}-V\right) / A_{\mathrm{HPR}}+h_{1} & \text { if }\left(V_{\mathrm{HPR}}>V\right)\end{cases}$

with $V$ being a conceptual parameter (see Section 4.4 .3 below). In order to simulate the non-linear discharge behaviour, an approach relating the reservoir base area to the hydraulic head within the reservoir is required. Therefore, the base area $A$ HPR of the HPR is decreased below $h_{1}$ to $A^{\prime}{ }^{\prime}{ }_{\text {HPR }}$ (Fig. 4.8). A similar approach was applied by Barrett and Charbeneau (1997) for modelling discharge at Barton springs (USA), a spring displaying a convex recession behaviour.

\subsubsection{Parameter estimation}

Three parameters of the model could be estimated by the analysis of the flow system. Additionally, the constricting conduit parameters were partly estimated from the flow system and literature values in order to constitute a combined calibration parameter.

\section{Spring catchment recharge area $A$ (by a combined water and chloride mass balance)}

For the 33 hydrological years of 1968-2000, total spring discharge volume was evaluated at ca. 305 million $\mathrm{m}^{3}$. This is equivalent to an average of 9.2 million $\mathrm{m}^{3} \mathrm{a}^{-1}$. Precipitation measured at Jerusalem meteorological station was on average $556 \mathrm{~mm} \mathrm{a}^{-1}$ for the period. According to our own precipitation measurements (Section 4.3.4) this value was assumed to be representative for the recharge area of the springs on a long-term basis. For the Auja spring catchment, a mean long-term average groundwater recharge fraction of precipitation of $34 \%$ was derived independently by a chloride mass balance (Schmidt et al., 2013). Accordingly, the average groundwater recharge for the period was $189 \mathrm{~mm} \mathrm{a}^{-1}$. With these data, the catchment recharge area $A$ was calculated at: $A=9.2 * 10^{6} \mathrm{~m}^{3} \mathrm{a}^{-1} / 0.189 \mathrm{~m} \mathrm{a}^{-1}=49 \mathrm{~km}^{2}$.

\section{SEM partitioning coefficient $x$ (by event analysis)}

The surface area of module SEM 1 AsEM 1 could be estimated by the results of the event analysis (Section 4.3.2), based on three assumptions: (1) after a preceding recharge event, there is no soil 
moisture deficit in SEM 1, therefore the following precipitation event $P_{\text {event, }}$ corrected is exclusively converted to groundwater recharge, (2) for the subsequent small to medium recharge events, groundwater discharge $Q_{\text {event }}$ measured at the spring equals groundwater recharge, and (3) for those small to medium events, only the module SEM 1 is contributing to recharge.

$\operatorname{Asem} 1\left(\mathrm{~m}^{2}\right)=Q_{\text {event }}\left(\mathrm{m}^{3}\right) / P_{\text {event, corrected }}(\mathrm{m})$

Nevertheless, between the events evapotranspiration occurs (ETapre-event), leading to a small depletion in SMS which has to be accounted for. This depletion might be partly compensated by small precipitation events $P$ pre-event, which are likewise considered:

$P_{\text {event }}$ corrected $=P_{\text {event }}-$ ETapre-event $+P_{\text {pre-event }}$

The small to medium rainfall-discharge events of 2010 appeared to be particularly suitable for the calculation, because the time elapsed between events was small and the events "2010-2" and "2010-3" were the two largest medium recharge events of the high-resolution time series (Table 4.2). The calculated surface area for SEM 1 is ca. $17 \mathrm{~km}^{2}$ (event 2010-2) and $12 \mathrm{~km}^{2}$ (event 2010-3), respectively; the combined event reveals a value of nearly $14 \mathrm{~km}^{2}$. This value is equivalent to $28 \%$ of the total catchment recharge area of $49 \mathrm{~km}^{2}$ (previous section), therefore $x=0.28$.

\section{Conceptual volume $V$ of the highly permeable reservoir (by combined event and recession analysis)}

The volume $V$ of the part of the HPR below $h_{1}$ is a conceptual parameter from which $A^{\prime}$ HPR can be calculated, once the parameter $h_{1}$ is calibrated $\left(A^{\prime}{ }_{\mathrm{HPR}}=V / h_{1}\right)$. It could be estimated from the discharge hydrographs of the years 2009 and 2010. Since both years displayed comparatively low recharge amounts, the discharge condition above the threshold was only maintained for about one month each year, therefore the LPR is assumed to receive only little recharge by cross-flow from the HPR. Accordingly, with gradients reversed, only a small discharge contribution from the LPR to total spring flow is assumed. Therefore, the discharged volume after the point where discharge is falling below the flow threshold (post-plateau recession) is indicative of $V$. The integrated discharge volume was ca. 1.1 million $\mathrm{m}^{3}$ for 2009 and 1.3 million $\mathrm{m}^{3}$ for 2010, respectively (Fig. 4.4, $V_{2009}$ and $V_{2010}$ ). The duration of post-plateau recession was very comparable for the two years with 82 and 81 days, respectively. In contrast, integrated post-plateau discharge for 2012 was nearly 3 million $\mathrm{m}^{3}$ with a considerably longer post-plateau recession period, presumably due to high LPR-HPR cross-flow. The mean value of 1.2 million $\mathrm{m}^{3}$ calculated for the years 2009 and 2010 was used.

\section{Constricting conduit properties}

The restricting conduit length $L$ was approximated from the maximum possible length of the catchment area of about $19 \mathrm{~km}$ (from Auja spring till the groundwater basin divide to the northwest) at $10 \mathrm{~km}$. The conduit roughness was intended to be close to the ratio of $\varepsilon / D=0.25$ as reported by Jeannin (2001). The conduit parameters can then be constrained by the observed outflow threshold at $0.47 \mathrm{~m}^{3} \mathrm{~s}^{-1}$ (Section 4.3.2). 


\subsubsection{Model calibration and input data provision}

Model calibration was based on three objectives/constraints: (1) to retain the water budget during the calibration period of October 1967 to September 2000 (calculated total deep percolation = measured total discharge volume of 305 million $\mathrm{m}^{3}$ ), (2) to match the simulated spring hydrograph to the measured data, and (3) to optimise the Nash-Sutcliffe efficiency criterion (Nash and Sutcliffe, 1970). A criterion based on square root transformed values (NSEsqrt) was applied, because it is sensitive for both low and high flow periods (e.g. Perrin et al, 2003; Oudin et al., 2006; Pushpalatha et al., 2012). The period of January 1964 to September 1967 was considered as a "warm-up period" for the model. The simulation was extended until September 2012. For the period of 2001-2008, no reliable flow data were available. The high-resolution data of 2009-2012 provided the validation period.

Daily precipitation data of Jerusalem station served as the input to the SEM for the period of 1964-2007. The daily arithmetic average precipitation depth of three highland area stations (Kafr Malik, Taybeh, Mazra'a ash-Sharqiya) was used as the input for the period of 2008-2012. The average value represents ca. $99 \%$ of the precipitation depth measured at Jerusalem. For the calculation of ETp during the period of 1964-2007, the air temperature data of Jerusalem station were used. For the period of 2008-2012, data from Kafr Malik station, adjusted to the Jerusalem temperature data, were selected. For a data gap during the hydrological year 2009, the Jerusalem data were used. For the 1st of January 1964, initial values for all four sub-modules were provided.

Six parameters of the reservoir model needed to be calibrated: two of the soil/epikarst module (FC 1 and FC 2) and four of the aquifer module (AHPR, ALPR, LEP, and the combined restricting conduit parameter represented by $h_{1}$ ). The first step of the calibration strategy comprised the selection of plausible field capacity values of the SEM in order to generate deep percolation for years with low precipitation depth (e.g. winter of 1998/1999). The second step comprised the calibration of the parameters for the restricting conduit to an outflow rate of $0.47 \mathrm{~m}^{3} \mathrm{~s}^{-1}$. Different combinations of $L, D, \varepsilon$, and $h_{1}$ were tested and model results appeared to be insensitive to combined changes in the parameters $L, D$, and $\varepsilon$ (Fig. 4.11). In contrast, $h_{1}$ appears to be a more sensitive parameter and is regarded as the main calibration parameter for the conduit restriction. The model parameters were optimised iteratively, applying the criteria stated above. The "optimum" parameter set was found at a NSEsqrt of 0.8 . For the validation period, a NSEsqrt of 0.77 was obtained.

\subsubsection{Modelling results}

The modelled and measured data generally match well (Fig. 4.9). In particular, the model is able to reproduce: (1) the plateau in discharge, (2) the initial peak superimposed on the plateau, and (3) the highly variable discharge conditions observed. From the values of $V$ (estimated, 1.2 million $\mathrm{m}^{3}$ ) and $h_{1}$ (calibrated, $100 \mathrm{~m}$ ), the base area of the lower part of the HPR ( $A^{\wedge}{ }_{\mathrm{HPR}}$ ) was calculated at $12000 \mathrm{~m}^{2}$. A HPR was calibrated to $0.2 \mathrm{~km}^{2}$, and ALPR to $1 \mathrm{~km}^{2}$, respectively. The LEP was calibrated to $3500 \mathrm{~m}^{2} \mathrm{~d}^{-1}$. Hence, the interface area $A$ Exc between the two reservoirs was calculated at ca. $0.9 \mathrm{~km}^{2}$ applying Eq. (4.8) with the recession coefficient $\alpha$ of the low permeability reservoir $\left(0.004 \mathrm{~d}^{-1}\right)$. 


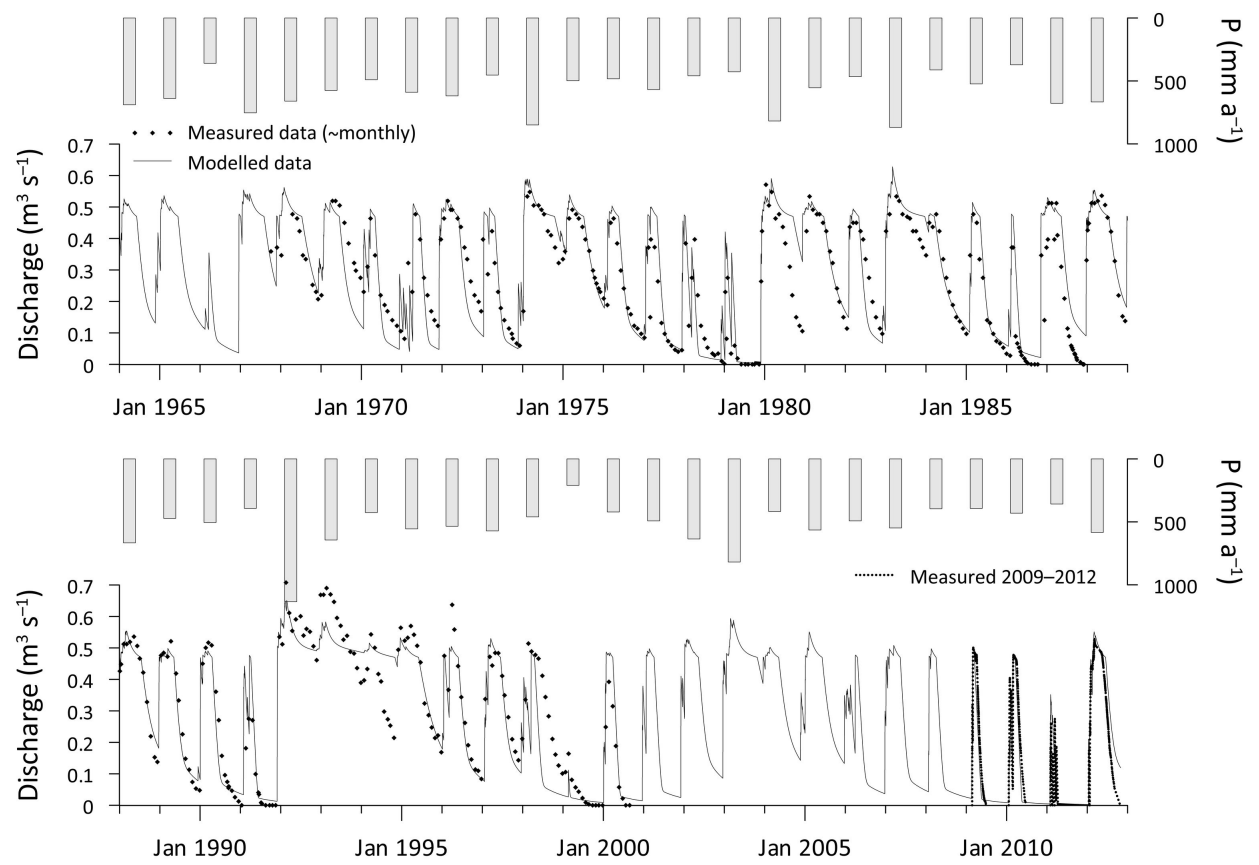

Fig. 4.9: Comparison of measured and modelled spring discharge (discharge data 1967-2000: Palestinian Water Authority, Ramallah).

The 45 -year modelling results reveal that on average $96 \%$ of the groundwater recharge occurs during the four month period of December to March. The combined average recharge for April and November is 4\%. Annual precipitation ranged from 210 to $1130 \mathrm{~mm}$. Calculated annual ETa in general ranged between 300 and $420 \mathrm{~mm}$ (mean $360 \mathrm{~mm}$ ). The hydrological year of 1999 displayed only $209 \mathrm{~mm}$, due to limited precipitation. Two hydrological years with considerable precipitation amounts during the time period of mid to late April, replenishing soil moisture storage, provided 450 and $460 \mathrm{~mm}$ of ETa. The calculated annual recharge range varied between $1 \mathrm{~mm}$ and $780 \mathrm{~mm}$ during the modelling period (Fig. 4.10). The five hydrologic years with the highest annual precipitation during the modelling period (1974, 1980, 1983, 1992, and 2003; all $>800 \mathrm{~mm} \mathrm{a}^{-1}$ ) also displayed the highest calculated groundwater recharge. They provided $33 \%$ of the integrated modelled recharge. In contrast, the 14 hydrologic years with the lowest recharge amounts caused less than $10 \%$ of the integrated groundwater recharge (Fig. 4.10).

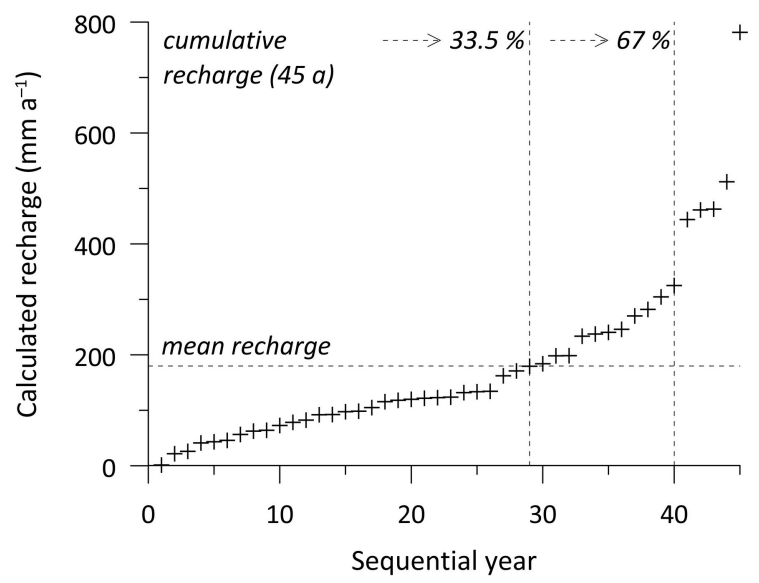

Fig. 4.10: Annual groundwater recharge (in fact: deep percolation), calculated by the reservoir model for 45 individual hydrological years, sorted in ascending order. Groups of 29, 11, and 5 hydrological years each account for about one third of total modelled recharge. 


\subsubsection{Sensitivity analysis}

The sensitivity of single model parameters on model results was analysed to investigate the predictive power of the model and to identify those model parameters that the discharge variability is most sensitive to and that have to be determined independently (if possible). NSEsqrt was used as a quantitative criterion (Fig. 4.11). FC 1 was varied with accompanying changes in FC 2 to fulfil the water budget constraint. Varying the conduit parameters $L$ and $h_{1}$ required adjustment of the other conduit parameters to match a flow threshold of $0.47 \mathrm{~m}^{3} \mathrm{~s}^{-1}$. As an "optimum" parameter set, not the set with the highest NSEsqrt was selected. For example, a FC 1 value of $90 \mathrm{~mm}$, despite overall good simulation results, would result in no recharge for 1999 which does not correspond to field observations. Similarly, an ALPR of $1.3 \mathrm{~km}^{2}$ would provide a higher NSEsqrt but would result in a less optimal match of the recession behaviour.
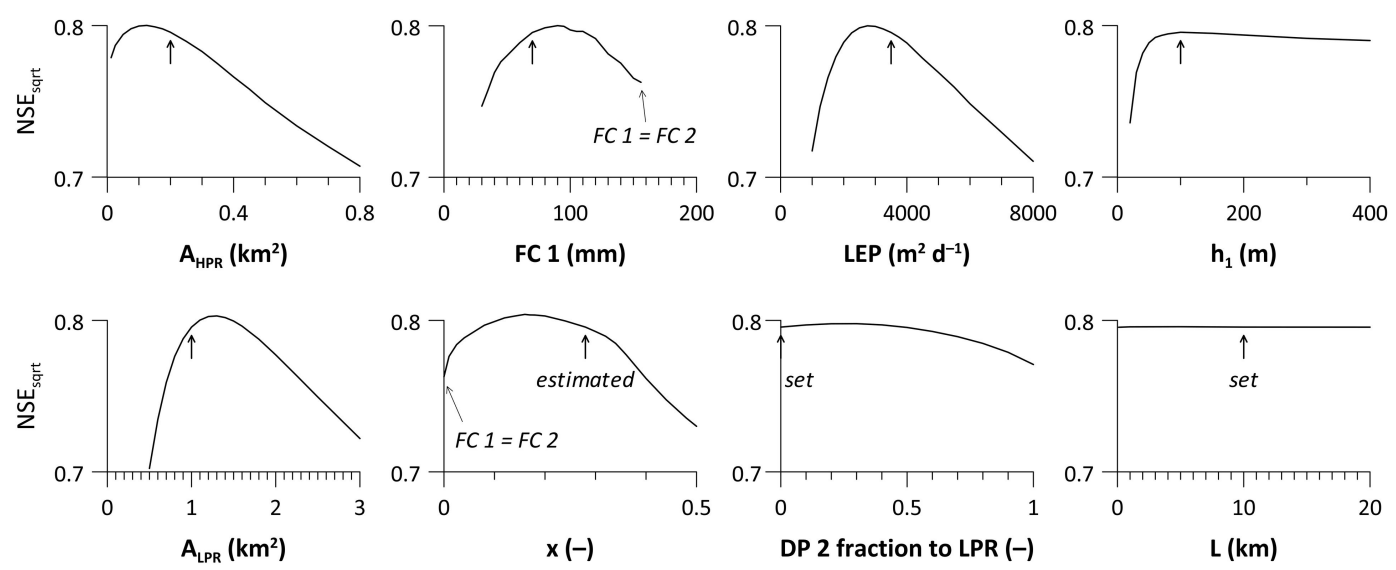

Fig. 4.11: Sensitivity of selected model parameters. The arrows indicate the values of the "optimum" calibrated parameter set, based also on the subjective judgement of the simulation results.

\subsection{Discussion}

\subsection{Hydrograph and recession analysis}

The hydrograph of Auja spring shows a complex discharge and recession behaviour. A flow threshold at ca. $0.47 \mathrm{~m}^{3} \mathrm{~s}^{-1}$ was observed. Above the threshold, the flow regime is considered as conduit restricted, resulting in an inclined plateau in the observed spring hydrograph. Below the threshold, small to medium recharge events lead to marked spring flow events closely succeeding precipitation input (Fig. 4.4). According to the considerations of Covington et al. (2009), this contrasting discharge behaviour might be classified into the flow regimes "(aquifer) geometry dominated" (flow threshold exceeded) and "recharge dominated" (below threshold).

The initial higher discharge peak above the plateau, recorded during March 2012 (Figs. 4.4 and 4.5), is also recognisable in some other years, e.g. during early 1974, 1983, and 1992 (Fig. 4.9). This phenomenon is recognised in other conduit restricted flow datasets as well (e.g. Herman et al., 2008, stage data). Here it is interpreted as an initial high water level within the highly permeable system (i.e. karst shafts) following extensive recharge (compare Fiorillo, 2011). Due to transfer of 
water from the highly permeable structures to other aquifer compartments, the initial local high hydraulic head is more evenly distributed in the system. The groundwater head in the highly permeable reservoir subsequently declines due to outflow of water by spring discharge and water transfer to the low permeability matrix, leading to a slightly inclined discharge plateau $(\alpha \approx$ $\left.0.0009 \mathrm{~d}^{-1}\right)$. In other conduit restricted aquifers, "excess" recharge is discharged by overflow springs, which is expected to produce a more level plateau (see e.g. Figure 4.11 in Smart, 1983). In contrast, the inclined plateau in the Auja flow system indicates that "excess" recharge is retained within the system and only gradually released.

Only a part of the large number of observed recession coefficients $\alpha$ below the plateau is assumed to reflect physically based system values, e.g. the baseflow recession coefficient of the low permeable rock matrix of $0.004 \mathrm{~d}^{-1}$. This value is very similar to the baseflow recession values evaluated for other karst spring systems: $0.004 \mathrm{~d}^{-1}$ (median) for Foux de la Vis (Forkasiewicz and Paloc, 1967), $0.006 \mathrm{~d}^{-1}$ for Ombla spring (Milanovic, 1981), $0.002 \mathrm{~d}^{-1}$ for Gallusquelle (Sauter, 1992), and $0.006 \mathrm{~d}^{-1}$ for Fountaine de Vaucluse (Fleury et al., 2007). Most of those studies relate this lowest recession coefficient to the drainage of (small) fractures in the saturated zone. Fleury et al. (2007), state that this water may also originate in part from the epikarst or the vadose zone. The recession coefficient of the main conduit system was estimated at about $0.2 \mathrm{~d}^{-1}$. The higher coefficients around $0.8 \mathrm{~d}^{-1}$ are attributed to the only partial filling of the main conduit system due to limited recharge. Comparable values were derived for other systems: $0.5 \mathrm{~d}^{-1}$ (median) for Foux de la Vis (Forkasiewicz and Paloc, 1967), $0.13 \mathrm{~d}^{-1}$ for Ombla spring (Milanovic, 1981), and $0.25 \mathrm{~d}^{-1}$ for Gallusquelle (Sauter, 1992).

Some small discharge events displayed a linear flow recession, assumed to reflect the drainage of a conduit system without matrix contribution (Bailly-Comte et al., 2010; Fiorillo, 2011). For those events, $\beta$-values around $0.02 \mathrm{~m}^{3} \mathrm{~s}^{-1} \mathrm{~d}^{-1}$ were derived (Table 4.2). Bailly-Comte et al. (2010) calculated a considerably higher value of about $1 \mathrm{~m}^{3} \mathrm{~s}^{-1} \mathrm{~d}^{-1}$ for the Vene spring in France. They relate high values of $\beta$ to a large flow section of the conduit, hence to a high degree of karstification. The $\alpha$ and $\beta$ recession coefficients may be used in subsequent works as independent parameters for pipe flow. The intermediate recession coefficients (Table 4.2) are assumed to be the result of the variable hydraulic head and cross-flow between the conceptualised two aquifer compartments.

\subsubsection{Reservoir model and water balance}

A reservoir model was set up and calibrated in order to refine the conceptual model and used as the main quantitative evaluation tool. In contrast to modelling studies for which calibration is based on the shape of the hydrograph alone, in this study, the long-term water balance is also a primary calibration constraint. Since the water balance of a short period, especially in semi-arid environments, can be biased with respect to extreme hydrometeorological conditions (wet and dry), in this study an extended (33-year) calibration period was used. In this study, also the recession coefficients for the reservoirs are not fixed or calibrated (e.g. Fleury et al., 2007; Geyer et al., 2008) but are simply the result of model geometry and variable cross-flow. The outflow restriction was incorporated by using a physical pipe representation in combination with a groundwater head-dependent reservoir base area. The simulated drainage behaviour of the highly permeable reservoir without cross-flow below $h_{1}$ is linear $\left(\beta \approx 0.008 \mathrm{~m}^{3} \mathrm{~s}^{-1} \mathrm{~d}^{-1}\right)$. This 
behaviour resembles the observed shape of some small discharge events (Table 4.2, Fig. 4.4), and especially the straight line segments of the early post-plateau recessions of 2009 and 2010 with an observed $\beta$ of ca. $0.01 \mathrm{~m}^{3} \mathrm{~s}^{-1} \mathrm{~d}^{-1}$ (Fig. 4.4).

Despite the simplified representation of nature, it is assumed that the calibrated parameters of the reservoir model reflect physical properties of the system. The two calibrated soil/epikarst "field capacities" of 70 and $190 \mathrm{~mm}$ are in the range of values observed for other sites in the Eastern Mediterranean karst region with very similar precipitation characteristics compared to the study site. Shaffer et al. (2011) assessed a combined soil/epikarst field capacity of about $100 \mathrm{~mm}$ from an irrigation experiment above a small vadose cave (drip onset = indicator of recharge). Arbel et al. (2010) assessed very variable seasonal drip onset threshold values at precipitation totals between $120 \mathrm{~mm}$ and $340 \mathrm{~mm}$ for different cave drip sites located in one cave within a lateral distance of only $20 \mathrm{~m}$. Those values are the sum of the soil/epikarst field capacity and evapotranspiration from the soil store before field capacity is reached (assessed for the winter season 2005/2006). Hartmann et al. (2012a) calibrated lumped soil/epikarst field capacity values of $126 \mathrm{~mm}$ and 166 $\mathrm{mm}$ for five different lumped parameter models for Faria spring, located ca. $37 \mathrm{~km}$ north of Auja spring.

The base areas of the conceptual reservoirs in relation to the total recharge catchment area can be regarded as estimates of effective porosity (Section 4.4.2; Fiorillo, 2011). The calibrated values of $1 \mathrm{~km}^{2}$ for $A_{\text {LPR }}$ and $0.2 \mathrm{~km}^{2}$ for $A_{\text {HPR }}$ are roughly $2.0 \%$ and $0.4 \%$ of the total catchment area of $49 \mathrm{~km}^{2}$, respectively. The value of $2 \%$ for the LPR is a realistic effective "matrix" porosity for carbonate aquifers (compare e.g. Atkinson, 1977; Sauter, 1992; Kiraly, 2002). The porosity value of the HPR of $0.4 \%$ is about one order of magnitude higher than the porosity generally attributed to karst conduit systems, which were assessed by analysing the transport signals of the systems (e.g. Atkinson, 1977; Sauter, 1992). Nevertheless, this high HPR-value contradicts a strict matrixconduit differentiation, as widely applied in karst hydrogeology. In this modelling approach, it can be expected that the calibrated porosity of the HPR also incorporates higher permeable fractures. A considerable storage and hence porosity attributed to the highly permeable system in karst aquifers is also supported by recent hybrid continuum-discrete pipe flow modelling studies (e.g. De Rooij, 2008; Reimann et al., 2014) and termed "conduit-associated drainable storage" in Reimann et al. (2014).

Due to its presumed large spatial coverage, as well as the redistribution and focussing of infiltrated water within the soil/epikarst, the HPR receives the bulk of the recharge. This is supported by the delayed response of the groundwater head in the matrix (Fig. 4.7), attributed to transient conduit-matrix cross-flow. The effect of providing recharge to the LPR directly ("fraction to LPR" in Fig. 4.8) was assessed by a sensitivity analysis (Fig. 4.11). Adding up to $50 \%$ of recharge from DP 2 into the LPR had little effect on NSEsqrt but decreased the observed discharge dynamics. Hence, DP 2 was added to the HPR exclusively. The calculated interface area Amxc between both reservoirs of ca. $0.9 \mathrm{~km}^{2}$ is only an approximation because processes such as an unsteady-state head distribution inside the matrix or a possible head-dependent size of the interface area are not considered.

Despite the long-term equal precipitation amounts of Jerusalem gauging station and the recharge area of the springs, some larger discrepancies may be observed for individual storms, which are 
expected to influence model results. For example, during the large precipitation event of February 2010 (Table 4.2), cumulative precipitation was $147 \mathrm{~mm}$ for the highland area close to the spring (average of three rain gauges) and $196 \mathrm{~mm}$ for Jerusalem gauging station. Since the antecedent soil moisture storage was relatively high during February, a precipitation event of such magnitude leads to a massive area-wide groundwater recharge event. For a catchment area of $49 \mathrm{~km}^{2}$, a difference of $50 \mathrm{~mm}$ is equivalent to 2.5 million $\mathrm{m}^{3}$ of groundwater recharge. Those differences are expected to cause some deviations between measured and modelled spring hydrographs, e.g. during the period of 1969-1973. For example, during the winter season of 1968/1969, annual precipitation depth was $100 \mathrm{~mm}$ larger for Aqraba than for Jerusalem, indicating a generally higher amount in the north.

Calculated annual actual evapotranspiration (ETa) displayed a comparatively low variability for the modeled 45 year period (range 300-420 $\mathrm{mm} \mathrm{a}^{-1}$, excluding three outliers). Ryu et al. (2008) also observed, in a climatically similar region that the range of annual ETa was considerably lower than the range in annual precipitation. Flood runoff leaving the autogenic surface catchment of Wadi Auja was evaluated at $1.2 \%$ of cumulative precipitation during the monitoring period of 2010-2013 (Ries, 2013). Therefore, the amount of precipitation in excess of the evaporative demand will largely contribute to groundwater recharge. Because annual precipitation is highly variable in this semi-arid environment, annual groundwater recharge is even more variable. Ranges were from nearly zero to about $500 \mathrm{~mm} \mathrm{a}^{-1}$ (excluding one unusually wet year). Seasons with a low to average precipitation depth will normally not provide a large recharge amount. However, during wet years the system is considerably recharged.

\subsubsection{Implications for conduit restricted flow in the Jordan Valley region}

In the case study area, the springs Sultan and Duyuk (Fig. 4.2) are also expected to be characterised by conduit restricted flow. Due to its very stable discharge, Rosenthal and Kronfeld (1982) regarded Sultan spring as an underflow spring. Both springs are likely fault-controlled springs. A limited hydraulic conductivity of the fault zones located in the Coniacian-Maastrichtian sediments (chalk and chert), which are overlying the carbonate aquifer, can be assumed. Also the Dan spring, the main spring of the Upper Jordan River (see inset map in Fig. 4.2 for location) may be fault-controlled (Figure 1 in Hartmann et al., 2013). Its hydrograph displayed a convex recession behaviour (Rimmer and Salingar, 2006), alternatively attributed to a large aquifer storage volume and continuing percolation from the vadose zone (Rimmer and Salingar, 2006). In contrast to those springs, the Auja spring orifice is located in the carbonate aquifer unit itself, hence the conduit restricted behaviour is attributed to a limited developed terminal conduit segment (Section 4.2.3). An alternative line of argument is a change in seasonal recharge variability, e.g. a shift to a more extreme pattern following a change in climate from humid to semi-arid conditions. This might lead to a backing-up of groundwater flow within the conduit system. According to these examples and considerations, different mechanisms might be the reason for conduit restricted flow in the study area. 


\subsection{Conclusions}

In this study, a characterisation and modelling approach for conduit restricted karst aquifers was proposed and executed on the example of the Auja spring (Lower Jordan Valley). A combination of hydrometric monitoring, hydrogeological data analysis, and non-linear lumped parameter modelling was applied.

Classical hydrogeological methods, especially spring hydrograph monitoring and analysis as well as water budget calculations, provide the conceptual framework for the characterisation of conduit restricted aquifers and enable the estimation of a number of system parameters. For those purposes, the acquisition of a precise discharge hydrograph is obligatory. High-resolution data are preferable. For example, in the presented case, the presence of the flashy discharge peaks below the flow threshold is not well resolved by monthly data. Especially in semi-arid environments, prolonged drought and wet periods are present and groundwater flow and storage can be very transient. Therefore, long-term time series need to be obtained. In this study, a 33-year period was used for the calibration of the model, and since the bulk discharge amount could be assessed by monthly data, high quality data of this kind are very valuable. Using only the recently obtained high-resolution time series for analysis would easily lead to a misinterpretation of the system, i.e. the usually observed slow recession behaviour of the Auja spring during pluvial periods would have been fully missed. Here, the long-term low-resolution data and short-term high-resolution time series were successfully combined.

Semi-arid environments with a distinct seasonality in precipitation are particularly suited for a recession analysis, because prolonged hydrograph recessions, not interrupted by recharge, can be obtained. As precipitation is occurring as intensive and infrequent storms, sharp input signals are available. Furthermore, because precipitation depth displays a high interannual variability, input signals are also highly contrasting.

The reservoir model developed in this study can be regarded as relatively simplistic, despite the hydrogeological complexities encountered, which include: (1) the non-linear system behaviour at the flow threshold, (2) the considerable cross-flow between the highly permeable structures and the matrix of the aquifer (caused by the expected considerable hydraulic head differences in conduit restricted aquifers), and (3) spatially variable soil/epikarst properties. However, the last two features are also applicable for standard karst reservoir models. As a number of required parameters could be estimated from the analysis of the flow system the model only requires six calibration parameters, reducing the parameter ambiguity. The model can, for example, be used to predict spring discharge during the summer and autumn seasons for the planning of irrigated agriculture.

From a water management perspective, conduit restricted karst aquifers, if not drained by overflow springs, seem advantageous to the ones displaying free discharge. The conduit restricted flow mechanism prevents water from rapidly flowing out as soon as the threshold is reached. In this semi-arid region with prolonged drought periods, conduit restricted flow functions as a natural management instrument for aquifer discharge. 


\section{Acknowledgements}

This study was conducted within the framework of the multi-lateral research project "SMART Sustainable Management of Available Water Resources with Innovative Technologies" funded by BMBF (German Federal Ministry of Education and Research), references Nos. 02WM0802 and 02WM1081. Special thanks go to: Abu Ashraf, Abu Shadi, Ayman Shawana, Steffen Fischer, Mathias Toll, Andrea Hanf, Klaus Haaken, and many more people from Auja village for help in spring site constructions and fieldwork; teachers, school and water authority personnel for help in meteorological instrumentation; Mustafa Nuseibeh and coworkers for more than 30 years of superb spring gauging; the Palestinian Water Authority for data provision; Asaf Gotfeld, Akiva Flexer, Anat Yellin-Dror, and Nimrod Inbar for their helpful support and discussions; Joe Nadolski for proofreading the manuscript; Jannes Kordilla for programming support. The detailed and helpful comments of the anonymous reviewers were highly appreciated.

\section{References}

Allen, R.G., Pereira, L.S., Raes, D., Smith, M., 1998. Crop evapotranspiration: guidelines for computing crop water requirements. Irrigation and drainage paper 56, FAO, Rome.

ANTEA, 1998. Well development study of the Eastern Aquifer Basin, northern districts of Palestine, Volume 1: Interim report, conceptual model. Unpublished ANTEA report No. A11903.

Arbel, Y., Greenbaum, N., Lange, J., Inbar, M., 2010. Infiltration processes and flow rates in developed karst vadose zone using tracers in cave drips. Earth Surface Processes and Landforms 35, 1682-1693.

Atkinson, T.C., 1977. Diffuse flow and conduit flow in limestone terrain in the Mendip Hills, Somerset (Great Britain). Journal of Hydrology 35, 93-110.

Ayalon, A., Bar-Matthews, M., Schilman, B., 2004. Rainfall isotopic characteristics at various sites in Israel and the relationships with unsaturated zone water. Report GSI/16/04, Geological Survey of Israel, Jerusalem.

Bailly-Comte, V., Martin, J.B., Jourde, H., Screaton, E.J., Pistre, S., Langston, A., 2010. Water exchange and pressure transfer between conduits and matrix and their influence on hydrodynamics of two karst aquifers with sinking streams. Journal of Hydrology 386, 55-66.

Barberá, J.A., Andreo, B., 2012. Functioning of a karst aquifer from S Spain under highly variable climate conditions, deduced from hydrochemical records. Environmental Earth Science 65, 2337-2349.

Barrett, M.E., Charbeneau, R.J., 1997. A parsimonious model for simulating flow in a karst aquifer. Journal of Hydrology 196, 47-65.

Bauer, S., Liedl, R., Sauter, M., 2003. Modeling of karst aquifer genesis: Influence of exchange flow. Water Resources Research 39(10), 1285, doi:10.1029/2003WR002218.

Begin, Z.B., 1975. The geology of the Jericho sheet. Geological Survey of Israel, Bulletin 67, Jerusalem.

Bonacci, O., 1993. Karst springs hydrographs as indicators of karst aquifers. Hydrological Sciences Journal 38, 5162. 


\section{Characterisation and modelling of conduit restricted karst aquifers}

Bonacci, O., 2001. Analysis of the maximum discharge of karst springs. Hydrogeology Journal 9, 328-338.

Covington, M., Wicks, C., Saar, M., 2009. A dimensionless number describing the effects of recharge and geometry on discharge from simple karstic aquifers. Water Resources Research 45, W11410, doi:10.1029/2009WR008004.

Department of Land Settlement and Water Commissioner, 1947. Water measurements prior to October 1944. British Government of Palestine, Government Printer, Jerusalem.

De Rooij, R., 2008. Towards improved numerical modeling of karst aquifers: coupling turbulent conduit flow and laminar matrix flow under variably saturated conditions. PhD thesis, University of Neuchâtel, Neuchâtel.

Droogers, P., Allen, R.G., 2002. Estimating reference evapotranspiration under inaccurate data conditions. Irrigation and Drainage Systems 16, 33-45.

Eisenlohr, L., Király, L., Bouzelboudjen, M., Rossier, Y., 1997. Numerical simulation as a tool for checking the interpretation of karst spring hydrographs. Journal of Hydrology 193, 306-315.

Fiorillo, F., 2011. Tank-reservoir drainage as a simulation of the recession limb of karst spring hydrographs. Hydrogeology Journal 19, 1009-1019.

Fleury, P., Plagnes, V., Bakalowicz, M., 2007. Modelling of the functioning of karst aquifers with a reservoir model: application to Fontaine de Vaucluse (South of France). Journal of Hydrology 345, 38-49.

Forkasiewicz, J., Paloc, H., 1967. Le régime de tarissement de la Foux de la Vis, etude préliminaire, in: Hydrology of fractured rocks, vol. 1, proccedings of the Dubrovnik Symposium, October 1965, pp. 213-226.

Frumkin, A., Fischhendler, I., 2005. Morphometry and distribution of isolated caves as a guide for phreatic and confined paleohydrological conditions. Geomorphology 67, 457-471.

Garfunkel, Z., Ben-Avraham, Z., 1996. The structure of the Dead Sea basin. Tectonophysics 266, 155-176.

Gat, J.R., Dansgaard, W., 1972. Stable isotope survey of the fresh water occurrences in Israel and northern Jordan Rift Valley. Journal of Hydrology 16, 171-212.

Geyer, T., 2008. Process-based characterisation of flow and transport in karst aquifers at catchment scale. PhD thesis, University of Göttingen, Göttingen.

Geyer, T., Birk, S., Liedl, R., Sauter, M., 2008. Quantification of temporal distribution of recharge in karst systems from spring hydrographs. Journal of Hydrology 348, 452-463.

Goldscheider, N., Drew, D. (Eds.), 2007. Methods in karst hydrogeology. Taylor \& Francis, London.

Guttman, J., 2007. The karstic flow system in Uja area - West Bank: An example of two separated flow systems in the same area, in: Shuval, H., Dweik, H. (Eds.), Water resources in the Middle East: Israel-Palestinian water issues - from conflict to cooperation. Springer, Berlin, pp. 61-66.

Halihan, T., Wicks, C.M., Engeln, J.F., 1998. Physical response of a karst drainage basin to flood pulses: example of the Devil's Icebox cave system (Missouri, USA). Journal of Hydrology 204, 24-36.

Hanf, A., 2010. Estimation of groundwater recharge by modelling of soil moisture movement in a semi-arid catchment, Wadi Auja, West Bank. Unpublished MSc thesis, University of Göttingen, Göttingen.

Hargreaves, G.H., Samani, Z.A., 1985. Reference crop evapotranspiration from temperature. Applied Engineering in Agriculture 1, 96-99. 
Hargreaves, G.H., Allen, R.G., 2003. History and evaluation of Hargreaves evapotranspiration equation. Journal of Irrigation and Drainage Engineering 129, 53-63.

Hartmann, A., Lange, J., Vivó Aguado, A., Mizyed, N., Smiatek, G., Kunstmann, H., 2012a. A multi-model approach for improved simulations of future water availability at a large Eastern Mediterranean karst spring. Journal of Hydrology 468-469, 130-138.

Hartmann, A., Lange, J., Weiler, M., Arbel, Y., Greenbaum, N., 2012b. A new approach to model the spatial and temporal variability of recharge to karst aquifers. Hydrology and Earth System Sciences 16, 2219-2231.

Hartmann, A., Wagener, T., Rimmer, A., Lange, J., Brielmann, H., Weiler, M., 2013. Testing the realism of model structures to identify karst system processes using water quality and quantity signatures. Water Resources Research 49, 3345-3358.

Herman, H.K., Toran, L., White, W.B., 2008. Threshold events in spring discharge: evidence from sediment and continuous water level measurement. Journal of Hydrology 351, 98-106.

Jeannin, P.-Y., 2001. Modeling flow in phreatic and epiphreatic karst conduits in the Hölloch cave (Muotatal, Switzerland). Water Resources Research 37, 191-200.

Jensen, D.T., Hargreaves, G.H., Temesgen, B., Allen, R.G., 1997. Computation of ETo under nonideal conditions. Journal of Irrigation and Drainage Engineering 123, 394-400.

Kafri, U., Yechieli, Y. 2010. The role of hydrogeological base level in the formation of sub-horizontal caves horizons, example from the Dead Sea Basin, Israel. Environmental Earth Science 61, 1145-1152.

Király, L., 2002. Karstification and groundwater flow, in: Gabrovšek, F. (Ed.), Evolution of karst: from prekarst to cessation. Založba ZRC, Ljubljana, pp. 155-190.

Kirchner, J.W., 2006. Getting the right answers for the right reasons: linking measurements, analyses, and models to advance the science of hydrology. Water Resources Research 42, W03S04, doi:10.1029/2005WR004362.

Klein Tank, A.M.G., Wijngarrd, J.B., Konnen, G.P., Bohm, R., Demaree, A., Gocheve, M., Mileta, S., Pashiardis, L., Hejkrlik, C., Kern-Hansen, R., Heino, P., Bessemoulin, G., Muller-Westermeier, G., Tzanakou, M., Szalai, S., Palsdottir, D., Fitzgerald, D., Rubin, S., Capaldo, M., Maugeri, M., Leitass, A., Bukantis, A., Aberfeld, R., van Engelen, A.F.V., Forland, E., Mietus, M., Coelho, F., Mares, C., Razuvaev, V., Nieplova, E., Cegnar, T., López, J.A., Dahlstrom, B., Moberg, A., Kirchhofer, W., Ceylan, A., Pachaliuk, O., Alexander, L.V., Petrovic, P., 2002. Daily dataset of 20th-century surface air temperature and precipitation series for the European Climate Assessment. International Journal of Climatology 22, 1441-1453.

Klimchouk, A.B., Ford, D., Palmer, A., Dreybrodt, W. (Eds.), 2000. Speleogenesis: evolution of karst aquifers. National Speleological Society, Huntsville.

Kovács, A., Perrochet, P., Király, L., Jeannin, P.-Y., 2005. A quantitative method for the characterisation of karst aquifers based on spring hydrograph analysis. Journal of Hydrology 303, 152-164.

Kroitoru, L., Mazor, E., Gilead, D., 1985. Hydrologic characteristics of the Wadi Kelt and Elisha springs: scientific basis for water resources management. IAHS Publication 153, 207-218.

Lenz, R., 1969. Eine Strukturkarte von Westjordanien im Maßstab 1 : 250 000. Beihefte zum Geologischen Jahrbuch 81, 93-112.

Liedl, R., Sauter, M., Hückinghaus, D., Clemens, T., Teutsch, G., 2003. Simulation of the development of karst aquifers using a coupled continuum pipe flow model. Water Resources Research 39(3), 1057, doi:10.1029/2001WR001206. 


\section{Characterisation and modelling of conduit restricted karst aquifers}

Lisker, S., Vaks, A., Bar-Matthews, M., Porat, R., Frumkin, A., 2009. Stromatolites in caves of the Dead Sea fault escarpment: implications to latest Pleistocene lake levels and tectonic subsidence. Quaternary Science Reviews 28, 80-92.

Maillet, E., 1905. Essais d'hydraulique souterraine et fluviale. Hermann, Paris.

Maréchal, J. C., Ladouche, B., Dörfliger, N., Lachassagne, P., 2008. Interpretation of pumping tests in a mixed flow karst system. Water Resources Research 44, W05401, doi:10.1029/2007WR006288.

Milanovic, P.T., 1981. Karst Hydrogeology. Water Resources Publications, Littleton.

Nash, J., Sutcliffe, J.V., 1970. River flow forecasting through conceptual models part I-A discussion of principles. Journal of Hydrology 10, 282-290.

Nuseibeh, M., Nasser Eddin, T., 1995. Palestinian fresh water springs. Palestinian Consultancy Group, Jerusalem.

Oudin, L., Andréassian, V., Mathevet, T., Perrin, C., Michel, C., 2006. Dynamic averaging of rainfall-runoff model simulations from complementary model parameterizations. Water Resources Research 42, W07410, doi:10.1029/2005WR004636.

Palestinian Water Authority, 2000. Summary of Palestinian hydrologic data, Volume 1: West Bank. Palestinian Water Authority report, Ramallah.

Perrin, C., Michel, C., Andréassian, V., 2003. Improvement of a parsimonious model for streamflow simulation. Journal of Hydrology 279, 275-289.

Pushpalatha, R., Perrin, C., Moine, N.L., Andréassian, V., 2012. A review of efficiency criteria suitable for evaluating low-flow simulations. Journal of Hydrology 420, 171-182.

Reimann, T., Giese, M., Geyer, T., Liedl, R., Maréchal, J.C., Shoemaker, W.B., 2014. Representation of water abstraction from a karst conduit with numerical discrete-continuum models. Hydrology and Earth System Sciences 18, 227-241.

Ries, F., 2013. Local hydrological models and quantification of runoff for sub-basin Auja, in: Rahman, M.A. (Ed.), Deliverable 405-Local hydrological models and quantification of runoff. Unpublished report, BMBF IWRM R\&D Programme SMART, Göttingen, pp. 2-17.

Rimmer, A., Salingar, Y., 2006. Modelling precipitation-streamflow processes in karst basin: The case of the Jordan River sources, Israel. Journal of Hydrology 331, 524-542.

Rosenan, N., 1955. One hundred years of rainfall in Jerusalem: a homotopic series of annual amounts. Israel Exploration Journal 5, 137-153.

Rosenthal, A., Kronfeld, J., 1982. ${ }^{234} \mathrm{U}-238 \mathrm{U}$ disequilibria as an aid to the hydrological study of the Judea Group aquifer in eastern Judea and Samaria, Israel. Journal of Hydrology 58, 149-158.

Rushton, K.R., Eilers, V.H.M., Carter, R.C., 2006. Improved soil moisture balance methodology for recharge estimation. Journal of Hydrology 318, 379-399.

Ryu, Y., Baldocchi, D.D., Ma, S., Hehn, T., 2008. Interannual variability of evapotranspiration and energy exchange over an annual grassland in California. Journal of Geophysical Research 113, D09104, doi:10.1029/2007JD009263.

Sauter, M., 1992. Quantification and forecasting of regional groundwater flow and transport in a karst aquifer (Gallusquelle, Malm, SW. Germany). Tübinger Geowissenschaftliche Arbeiten C13, Tübingen.

Schmidt, S., Fischer, S., Toll, M., Ries, F., Zayed, O., Guttman, J., Marei, A., Weiss, M., Geyer, T., Sauter, M., 2012. Design and setup of a high resolution hydrometric monitoring network in a semi-arid karst environment 
- West Bank, in: Rausch, R., Schüth, C., Himmelsbach, T. (Eds.), Hydrogeology of arid environments. Borntraeger, Stuttgart, pp. 147-150.

Schmidt, S., Geyer, T., Marei, A., Guttman, J., Sauter, M., 2013. Quantification of long-term wastewater impacts on karst groundwater resources in a semi-arid environment by chloride mass balance methods. Journal of Hydrology 502, 177-190.

Sheffer, N.A., Cohen, M., Morin, E., Grodek, T., Gimburg, A., Magal, E., Gvirtzman, H., Nied, M., Isele, D., Frumkin, A., 2011. Integrated cave drip monitoring for epikarst recharge estimation in a dry Mediterranean area, Sif Cave, Israel. Hydrological Processes 25, 2837-2845.

Simmers, I., 1990. Aridity, groundwater recharge and water resources management, in: Lerner, D.N., Issar, A., Simmers, I. (Eds.), Groundwater recharge: a guide to understanding and estimating natural recharge. IAH, International Contributions to Hydrogeology 8, Heise, Hannover, pp. 1-20.

Smart, C.C., 1983. The hydrology of a glacierised alpine karst: Castleguard Mountain, Alberta. PhD thesis, McMaster University, Hamilton, Open Access Dissertations and Theses. Paper 1382. $<$ http://digitalcommons.mcmaster.ca/opendissertations/1382/>.

Smart, P.L., Hobbs, S.L., 1986. Characterisation of carbonate aquifers: a conceptual base, in: Graves, B.J., Lehr, J.H., Butcher, K., Crawford, N.C. (Eds.), Proceedings of the environmental problems in karst terranes and their solutions conference. Bowling Green, pp. 1-14.

Sneh, A., Bartov, Y., Weissbrod, T., Rosensaft, M., 1998. Geological map of Israel, 1:200,000. Geological Survey of Israel, on-line geological map, Jerusalem. <http://www.gsi.gov.il>.

Soulios, G., 1991. Contribution à l'étude des courbes de récession des sources karstiques: Exemples du pays Hellénique. Journal of Hydrology 127, 29-42.

Tallaksen, L.M., van Lanen, H.A.J. (Eds.), 2004. Hydrological drought: processes and estimation methods for streamflow and groundwater. Developments in Water Sciences 48, Elsevier, Amsterdam.

Waldmann, N., Stein, M., Ariztegui, D., Starinsky, A., 2009. Stratigraphy, depositional environments and level reconstruction of the last interglacial Lake Samra in the Dead Sea basin. Quaternary Research 72, 1-15.

Weiß, M., Menzel, L., 2008. A global comparison of four potential evapotranspiration equations and their relevance to stream flow modelling in semi-arid environments. Advances in Geosciences 18, 15-23.

White, W.B., 1969. Conceptual models for carbonate aquifers. Ground Water 7, 15-21.

Williams, P.W., 1983. The role of the subcutaneous zone in karst hydrology. Journal of Hydrology 61, 45-67.

Wong, C.I., Mahler, B.J., Musgrove, M., Banner, J.L., 2012. Changes in sources and storage in a karst aquifer during a transition from drought to wet conditions. Journal of Hydrology 468, 159-172. 
Characterisation and modelling of conduit restricted karst aquifers 


\section{Chapter 5}

\section{Evaluation of rapid recharge processes and spring source vulnerability of karst aquifers in semi-arid environments based on high-resolution monitoring}

Sebastian Schmidta ${ }^{a}$ Fabian Ries ${ }^{b}$, et al.

Manuscript:

Schmidt, S., Ries, F., et al.. Evaluation of rapid recharge processes and spring source vulnerability of semi-arid karst aquifers based on high-resolution monitoring. In preparation for submission to a peer-reviewed journal.

a University of Göttingen, Geoscience Centre, Applied Geology, Goldschmidtstraße 3, 37077 Göttingen, Germany

b University of Freiburg, Chair of Hydrology, Fahnenbergplatz, 79098 Freiburg, Germany 


\section{I Introduction}

Karstified carbonate aquifers constitute important sources of drinking water in many parts of the world (Ford and Williams, 2007). Yet, due to thin or absent soils, focussed (point) recharge, and rapid transport in integrated conduit systems, they are often highly vulnerable to microbial and chemical contamination (Quinlan et al, 1991; Daly et al., 2002; Foster et al., 2013). Karst springs are natural discharge points of karst aquifers and hence often preferred for water abstraction. Because of their direct connection to the conduit system, they are usually more vulnerable to the rapid appearance of contamination than less dynamic aquifer compartments, e.g. sections of the fractured rock matrix tapped by abstraction wells (e.g. Magal et al., 2013). A high variability of discharge and physicochemical parameters at springs is regarded as an indicator of high flow dynamics and hence high vulnerability (Quinlan et al, 1991; Pochon et al., 2008; Galleani et al., 2011). The dynamics of flow and transport are triggered by groundwater recharge. Comparatively higher aquifer vulnerability is expected in climates with high intensity and high magnitude precipitation events (Daly et al., 2002; Vias et al., 2010).

Because of their vulnerability, karst aquifers require a comprehensive groundwater protection scheme (Goldscheider, 2010; Foster et al., 2013). Conceptually, resource protection (concerning protection of the groundwater body as a whole) is distinguished from source protection (concerning protection of a specific abstraction point, i.e. an abstraction well or a spring) (Hötzl, 1996; Goldscheider, 2002). For resource protection purposes, vulnerability is often assessed by an index method and mapping approach, which subdivides the aquifer recharge area into zones with different protective functions, largely based on the hydraulic properties of the soil and the vadose zone (e.g. Daly et al., 2002; Mimi and Assi, 2009; Vias et al., 2010). For source protection, groundwater protection zones are established based on the preceding hydrogeological characterisation and vulnerability assessment (Frind et al., 2006; Goldscheider, 2010; Foster et al., 2013). Since vulnerability is often variable in time, dependent of the state of the hydrological system, a complementary assessment of vulnerability dynamics is necessary for source protection (Butscher and Huggenberger, 2008; Doummar, 2012). For example, reflecting the range in spring discharge, flow velocities in the conduit system can display large variations with time for a given karst aquifer (e.g. Göppert and Goldscheider, 2008; Doummar, 2012). For spring source vulnerability assessment and operative water supply management, the fast conduit flow component is critical. If one regards the fast flow component as potentially polluted (e.g. with respect to pathogen bacteria and viruses), the operative questions that need to be answered are: (1) when will the fast flow component reach the spring (time lag after precipitation/recharge event), (2) which fraction of this flow component will be present, and (3) for how long the breakthrough will prevail? (modified after Brouyère, 2004).

The fast flow component can be assessed by high-resolution monitoring of spring hydrographs and chemographs and their combined analysis (e.g. Dreiss, 1989; Ryan and Meiman, 1996). Discharge monitoring is preferably conducted at permanent gauging stations (e.g. weirs). Spring monitoring for various hydrochemical and physical parameters (e.g. electrical conductivity, temperature, major ions, stable water isotopes, etc.) is conducted classically by manual field measurements and (automatic) water sampling and laboratory analyses (e.g. Jakucs, 1959; Dreiss, 
1989; Liñán Baena et al., 2009). Depending on the sampling frequency and the accessibility of the spring, these measurements are very labour intensive. Physicochemical parameters and increasingly also certain ions can be continuously monitored using probes and data loggers, reducing the interval for field visits.

Many karst aquifers are located in areas of present dry sub-humid, semi-arid, or arid climate. In those climates, groundwater recharge is often restricted to episodic but intense precipitation events. This characteristic is assumed to lead to an alternation of distinct phases with high and low aquifer dynamics. In those environments, hydrogeological data and investigations are often scarce. Consequently, groundwater catchment areas are not delineated, the groundwater flow systems are unknown, and groundwater source protection is not feasible. High-resolution monitoring schemes to assess dynamic flow components were implemented only occasionally (e.g. Amiel et al., 2010). Especially the processes of groundwater recharge of (semi-)arid karst aquifers are not well investigated. In those environments, two potential mechanisms of focussed recharge can be taken into account: (1) a focussing of subcutaneous flow in the epikarst preferentially in closed depressions with subsequent rapid transfer through the vadose zone along karst shafts and major fractures (sensu Gunn, 1983; Williams, 1983) and (2) storm surface runoff infiltrating into small ponors or ponor zones in the ephemeral valleys ("thalweg ponors" sensu George, 1989; Ford and Williams, 2007). If the ephemeral karst valleys exhibit abundant alluvial sediments covering the ponors, water needs to infiltrate into the sediments first, frequently termed "transmission losses" (e.g. Shanafield and Cook, 2014). In any case, focussed recharge mechanisms apart from obvious large ponors are difficult to determine in the field. Previous studies employed monitoring of drip sites in caves, which indicate hydraulic response times of hours up to several weeks depending on the soil/epikarst moisture conditions preceding the natural or artificial precipitation (e.g. Arbel et al., 2010; Lange et al., 2010) or the thickness of the vadose zone (Williams, 1983).

The main objective of the present study is to evaluate rapid recharge processes and the vulnerability of the water sources (springs) of less-investigated karst aquifers in the semi-arid Eastern Mediterranean. The evaluation and the accompanying hydrogeological characterisation is based on the high-resolution monitoring of integral karst spring signal responses to recharge events. From those data, inferences on recharge processes and quantitative spring system parameters regarding vulnerability dynamics are deduced.

\subsection{Study area}

The carbonate aquifer system of the study area extends from the central mountain range of the West Bank and Israel (recharge area) to the Lower Jordan Valley (Fig. 5.1). Climate in the recharge area is semi-arid with winter season precipitation $\left(P_{\text {mean }} \approx 500-600 \mathrm{~mm} \mathrm{a}^{-1}\right)$, largely in form of intensive cold front rainstorms (Goldreich, 1994) with amounts of up to ca. $100 \mathrm{~mm} \mathrm{~d}^{-1}$ (data: European Climate Assessment and Dataset, http://eca.knmi.nl, Klein Tank et al., 2002). The aquifer complex is constituted by Cretaceous dolomite and limestone (Albian to Turonian stages) with a thickness of about $800 \mathrm{~m}$. The morphology is characterised by ephemeral valleys (wadis). 
It was characterised as Fluviokarst (sensu Sweeting, 1972) by Frumkin and Fischhendler (2005). Closed basins and associated karst shafts, however sometimes blocked with residual clay, are only present in small areas along the surface water divide (Frumkin, 1992; Fig. 5.1).

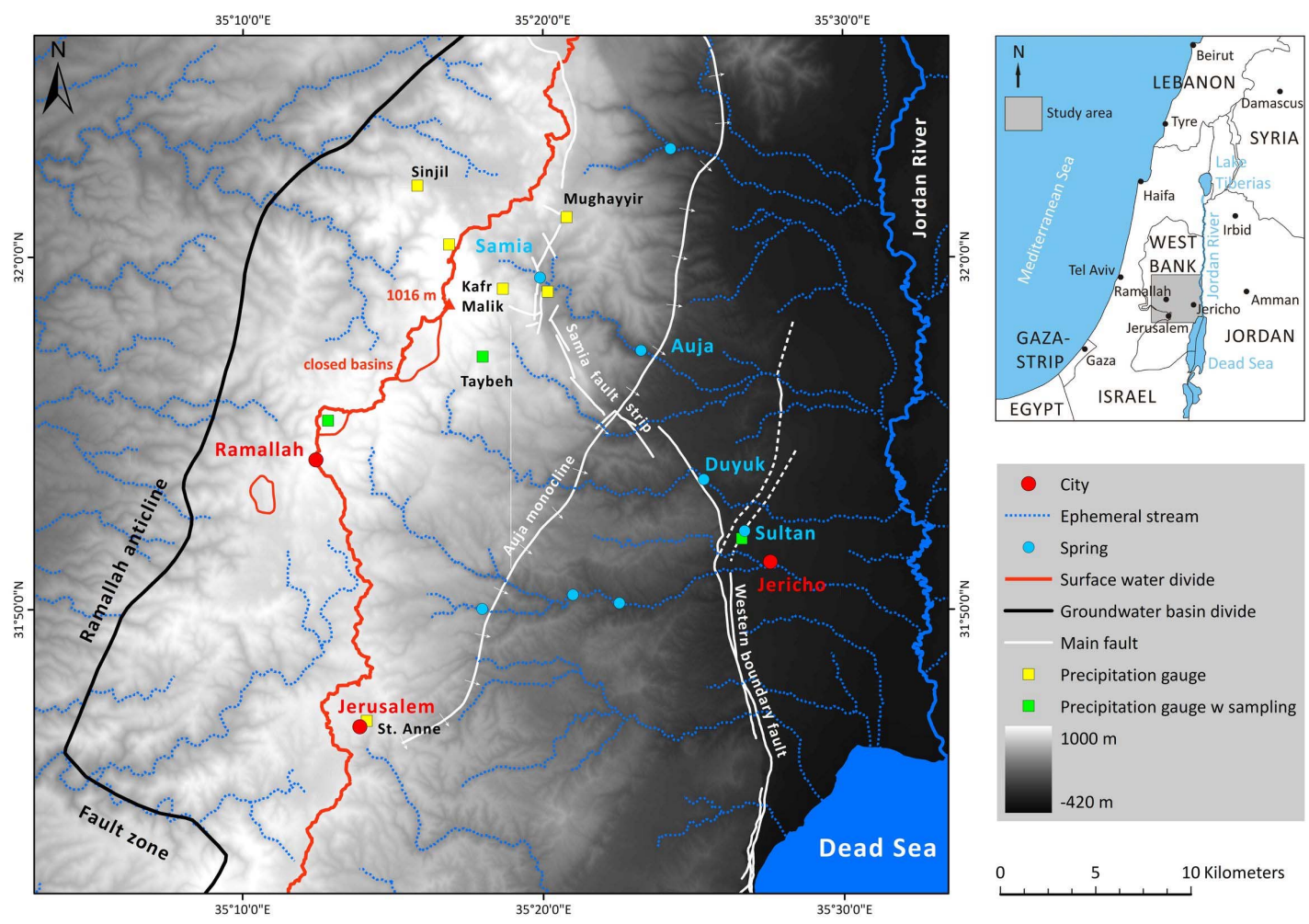

Fig. 5.1: Overview map of the study area. Areas of internal drainage (closed basins) modified after Frumkin (1992); groundwater divide after ANTEA (1998); Auja monocline after Lenz (1969).

Discharge of the upper sections of the aquifer complex (Rosenthal and Kronfeld, 1982) is predominantly taking place at springs in the slopes towards the Jordan Valley and in the Jordan Valley (Fig. 5.1). The largest springs are Auja, Duyuk, and Sultan with regional importance for drinking and irrigation water supply (Table 5.1). The groundwater quality of the aquifer system is threatened particularly by effluent and domestic waste disposal in parts of the aquifer recharge area (e.g Mimi and Assi, 2009). Hence an increasing wastewater-borne discharge component can be quantified for nearly all larger springs (Schmidt et al., 2013). The location of the recharge catchment areas of the springs are unknown and the hydrogeology of the spring flow system is not well understood.

Table 5.1: Summary of the long-term discharge data (hydrological years 1968-2000) for the springs covered in this study. Data courtesy of the Palestinian Water Authority.

\begin{tabular}{lcccc}
\hline Spring & Elevation $(\mathrm{m}$ asl $)$ & $Q_{\operatorname{mean}}\left(\mathrm{l} \mathrm{s}^{-1}\right)$ & $Q_{\min }\left(\mathrm{l} \mathrm{s}^{-1}\right)$ & $Q_{\max }\left(\mathrm{l} \mathrm{s}^{-1}\right)$ \\
\hline Sultan (Elisha) & -215 & 180 & 140 & 200 \\
Duyuk $^{\mathrm{a}}$ & -110 & 260 & 180 & 340 \\
Auja & 20 & 290 & 0 & 710 \\
Samia $^{\mathrm{b}}$ & 435 & 21 & not determined & not determined \\
\hline
\end{tabular}

a Combined discharge of the hydrochemical identical outlets Duyuk, Nueima, and Shosah, constituting the spring.

$\mathrm{b}$ The aquifer of Samia spring is tapped by an abstraction well, located about $100 \mathrm{~m}$ from the spring orifice. Therefore, except after heavy precipitation events, no water is discharging from the spring orifice. Mean discharge given refers to the mean longterm abstraction rate of the well (Palestinian Water Authority, 2000). 


\subsection{Methods}

An extensive hydrometric and hydrochemical monitoring programme and network was initiated in autumn 2007 and is conducted to date (Schmidt et al., 2012, 2014; Ries, 2013). The focus monitoring period of this study was from November 2010 until September 2012, when the four main springs (Table 5.1) were continuously monitored, representing a very dry year succeeded by an above average wet year. For the springs Auja and Sultan, the data analysis started from autumn 2008.

\subsection{Monitoring of spring discharge and physicochemical parameters}

At the low discharge variability springs Sultan and Duyuk discharge measurements were periodically performed by the salt dilution method, usually in winter/spring (relative high flow conditions) and autumn (relative low flow conditions). At the high discharge variability springs Auja and Samia, permanent V-notch weirs with continuous head recording facilities were installed in 2008 (Auja) and 2011 (Samia). For both stations, rating curves were established by measurements with the salt dilution method. At the Samia spring, discharge measurements are perturbed by: (1) the simultaneous recording of spring flow and ephemeral wadi runoff and (2) periodical water abstraction from the spring aquifer. To calculate discharge during periods of wadi runoff, a rating curve between measured groundwater head in the aquifer and spring discharge was established. For (2), discharge was interpolated between abstraction-free periods or discharge was corrected for abstraction quantities, respectively.

The springs were furthermore equipped with multi-parameter-probes connected to data loggers (Table 5.2). Electrical conductivity (EC) is given as specific electrical conductivity corrected to a reference temperature of $25{ }^{\circ} \mathrm{C}$. Chloride concentration at the Sultan spring was temporarily recorded by an ion sensitive electrode as a voltage signal. As the signal displayed a drift, it was corrected for linear trend and converted to chloride concentration by correlation with the results from the simultaneously conducted water sampling.

Table 5.2: Automatically monitored spring parameters (in brackets = only sub-period monitored) and temporal resolution.

\begin{tabular}{|c|c|c|c|c|}
\hline Spring & Start & Parameters $^{\mathrm{a}}$ & Monitoring devices & Interval (min) \\
\hline Sultan & Dec 2007 & $\mathrm{EC}$, (Turb., $\left.\mathrm{Cl}^{-}\right)$ & MPS-D (Seba Hydrometrie GmbH) & 5 \\
\hline Auja & Dec 2008 & $(Q, E C$, Turb. $)$ & $\begin{array}{l}\text { MPS-D, Dipper-TEC (Seba Hydrometrie) } \\
\text { Micro-Diver (Schlumberger Water Services) } \\
\text { HOBO U20 (Onset Computer Corporation) }\end{array}$ & $5-15$ \\
\hline Samia $^{\mathrm{b}}$ & Mar 2010 & $(Q, E C), W L$ & CDT-Diver, Micro-Diver (Schlumberger) & $20-40$ \\
\hline Duyuk & Nov 2010 & $(\mathrm{EC})$ & Dipper-TEC (Seba Hydrometrie GmbH) & 20 \\
\hline
\end{tabular}

a Subset of the relevant monitoring parameters for this study: Q: discharge, EC: electrical conductivity, WL: water level in spring aquifer, Turb.: turbidity, $\mathrm{Cl}^{-}$: chloride concentration.

b Physicochemical parameters and water level at the Samia spring were measured in the abstraction well, located about $100 \mathrm{~m}$ from the spring orifice. Spring discharge is measured at a V-notch weir a few meters downstream of the spring. 


\subsubsection{Monitoring of chloride concentration in precipitation and spring water}

Precipitation samples for chloride analysis were collected at Ramallah, Taybeh, and Jericho (Fig. 5.1), employing precipitation collectors (RS200, UMS GmbH). The precipitation water retained within the device is largely protected from evaporation and was filled in polyethylene bottles as soon as possible after the precipitation event. Precipitation intensity and -depth was measured with automatically logging rain gauges (RG3-M, Onset Computer Corporation) mounted in the vicinity of the precipitation collectors and also at various other locations in the presumed recharge area of the springs. For the large precipitation events, monitored by more than one sample, the precipitation volume weighted mean chloride concentration was calculated.

Water of Sultan spring was sampled about weekly during summer and autumn and from daily to twice a week during the precipitation season. From the other springs, a number of samples were obtained during high flow and low flow conditions. Chloride concentration was determined by standard ion chromatography.

Before the onset of extensive anthropogenic activities, Sultan spring was monitored for chloride concentration and discharge (sharp-crested weir) during the years 1938-1940 by the Irrigation Service of the British Government of Palestine (Department of Land Settlement and Water Commissioner, 1947). Daily precipitation amount was measured at gauging station St. Anne, located in the old city of Jerusalem (data source: http://eca.knmi.nl; for location see Fig. 5.1).

\subsubsection{Estimation of the conduit volume of karst spring flow systems}

The much faster propagation of a recharge event hydraulic signal in karst aquifers in relation to the transport signal was first recognised by Jakucs (1959), who furthermore expected a piston type flow mechanism in the conduit system. Ashton (1966) integrated the discharge volume between the onset of the hydraulic signal (rise in discharge) until the arrival of the transport signal (drop in water hardness) in order to obtain an estimate of the volume of the conduit system (Fig 5.2). Williams (1983) considered that a frequently observed initial rise in the water hardness/electrical conductivity before the breakthrough is to be related to a flow contribution from the epikarst zone characterised by an elevated hardness. Hereinafter this method is referred to as lag time method (Birk et al., 2006) and an estimate for the conduit volume $V_{c}$ is calculated by the following equation:

$$
V_{C}=\int_{t_{0}}^{t_{1}} Q
$$

with $Q$ as spring discharge $\left(\mathrm{m}^{3} \mathrm{~s}^{-1}\right)$, $t_{0}$ time at the onset of the hydraulic signal, and $t_{1}$ time at the first arrival of the event water. For the determination of to either (1) the relative discharge minimum before the rising limb of the event or (2) the onset of the autochthonous turbidity signal (resuspension of particles due to pressure transfer in the conduit system, Massei et al., 2003) was used (Fig. 5.2). For $t_{1}$ either (1) the last baseline electrical conductivity value before the breakthrough (Samia spring) or (2) the small electrical conductivity peak before the event breakthrough was considered, in order to obtain a clear cut determination of $t_{1}$ in the highresolution time series of the less dynamic large springs (Fig. 5.2). 


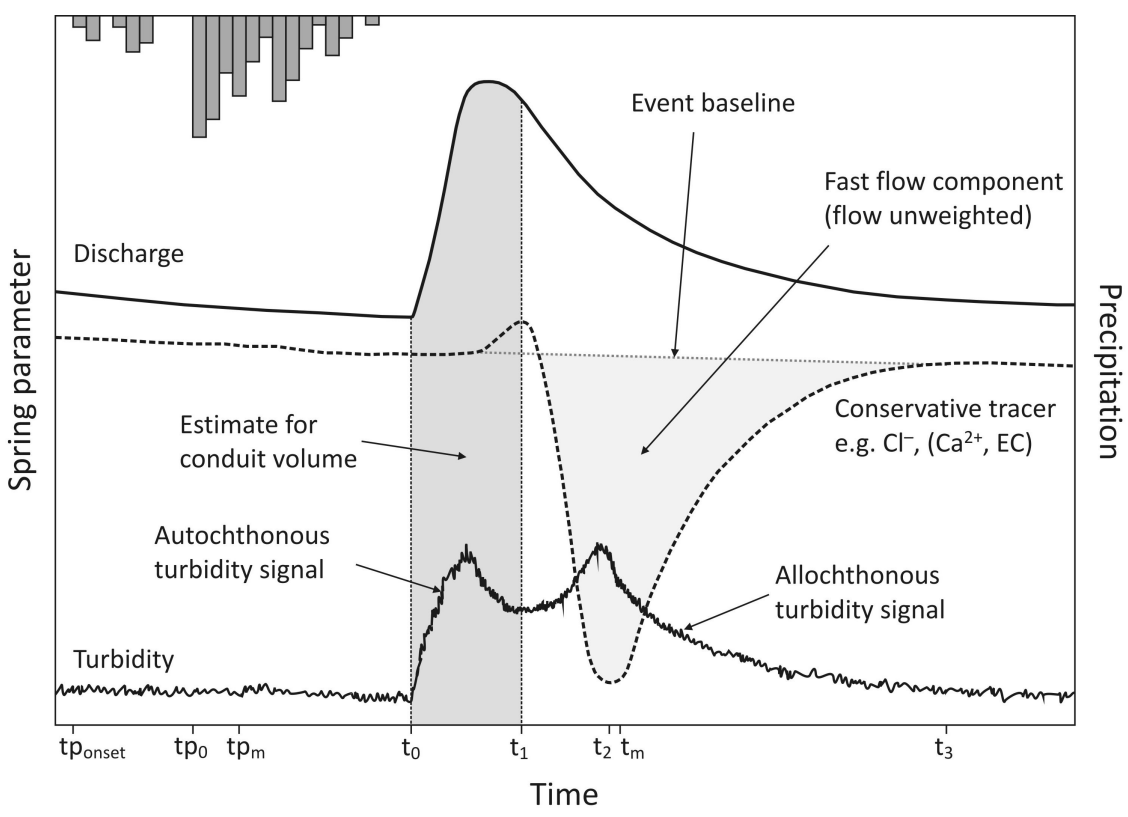

Figure 5.2: Characteristic times of precipitation events $(t p)$ and spring responses $(t)$ for estimation of conduit volumes by the lag time method as well as assessment of the fast flow component (subscript $m=$ median).

At Samia spring, the groundwater table is normally lower than the spring orifice due to periodic water abstraction. During intense precipitation events leading to groundwater recharge, the arrival of the hydraulic pulse was recognised by a sudden rise in water level in the well ( $t$ ) . However, groundwater level in the spring aquifer needed to recover about 10-25 m until spring outflow started at time $t_{s}$. The unknown flow volume between $t_{0}$ and $t_{s}$ was approximated by multiplication of the lag time $t_{0}-t_{s}$ with the mean spring flow calculated for the period between $t_{s}$ and $t_{1}$.

\subsubsection{Mixing model for hydrograph separation and anthropogenic impact quantification}

The relative fractions of waters with different concentrations of an environmental tracer in a binary mixture can be calculated by end-member mixing analysis, originally developed for streamflow separation (Pinder and Jones, 1969). In this study, chloride was used as tracer to calculate the fraction of (1) wastewater in groundwater $\left(F_{\mathrm{ww}}\right)$ or (2) rapidly recharged precipitation water in spring discharge $\left(F_{P}\right) . F_{\times}$is the fraction of the sought end member:

$$
F_{x}=\frac{\left(\mathrm{Cl}_{\mathrm{gw}}^{-}-\mathrm{Cl}_{\mathrm{b}}^{-}\right)}{\left(\mathrm{Cl}_{\mathrm{x}}^{-}-\mathrm{Cl}_{\mathrm{b}}^{-}\right)}
$$

with $\mathrm{Cl}^{-} x$ as the wastewater or precipitation end-member chloride concentration, $\mathrm{Cl}^{-} b$ the baseline (background) chloride concentration, and $\mathrm{Cl}^{-}$gw the measured groundwater chloride concentration. However, the simultaneous occurrence of both wastewater and precipitation water cannot be quantified by using chloride as the only tracer. If the precipitation event concentration was not measured, the mean precipitation weighted concentration of all monitored large events was used. As the baseline concentration of chloride is usually not stable during 
periods of high aquifer dynamics, the event water separation calculations were performed with an interpolated sloping baseline, if necessary (Fig. 5.2).

\subsubsection{Estimation of the mean residence time and discharge fraction of the fast flow component}

The mean residence time of the fast flow component $\mathrm{MRT}_{\text {ff }}$ was calculated from the time lag between the median of the precipitation event $t p_{m}$ and the median of the flow weighted fast flow component $t_{m}$. For the steady discharge spring Sultan, a steady event discharge was applied. In order to derive this value, either discharge was measured during the event or the long-term mean discharge rate (Table 5.1) was used.

\subsection{Results and discussion}

\subsection{General flow system properties deduced from the high-resolution monitoring}

The time series obtained at the four springs (Fig. 5.3), reveal important insights into the characteristics of the flow system.

\section{The coherence of the Jericho springs Sultan and Duyuk}

The electrical conductivity signal of Sultan spring is largely identical to the signal of Duyuk spring but displays a mean lag of about $0.7 \mathrm{~d}(n=37$ distinct minima or maxima, hydrological year of 2011). This is a strong indicator that both springs are fed by the same conduit system. The uniform time lag is attributed to the observed stable discharge rate of the Sultan spring (Table 5.1, Fig. 5.3). Rosenthal and Kronfeld (1982) postulated an underflow mechanism. This mechanism implies a flow restriction either in the conduit system of the aquifer or in the fault zone enabling the artesian rise of water through confining chalk sediments (compare Schmidt et al., 2014). The thickness of the confining sediments was estimated at about $180 \mathrm{~m}$ from surface geology and the typical layer thicknesses (data: Begin, 1975; Wolfer, 1998). It is expected that the conduit connecting Sultan spring to the overall Sultan/Duyuk flow system developed along the Ein Samia fault, characterised by a normal displacement (Begin, 1975). The linear distance between the Duyuk and Sultan springs is about $3500 \mathrm{~m}$. Hence, assuming a straight connection, the mean flow velocity is $220 \mathrm{~m} \mathrm{~h}^{-1}$, which is a typical value for karst conduit systems (compare Worthington and Smart, 2013). 


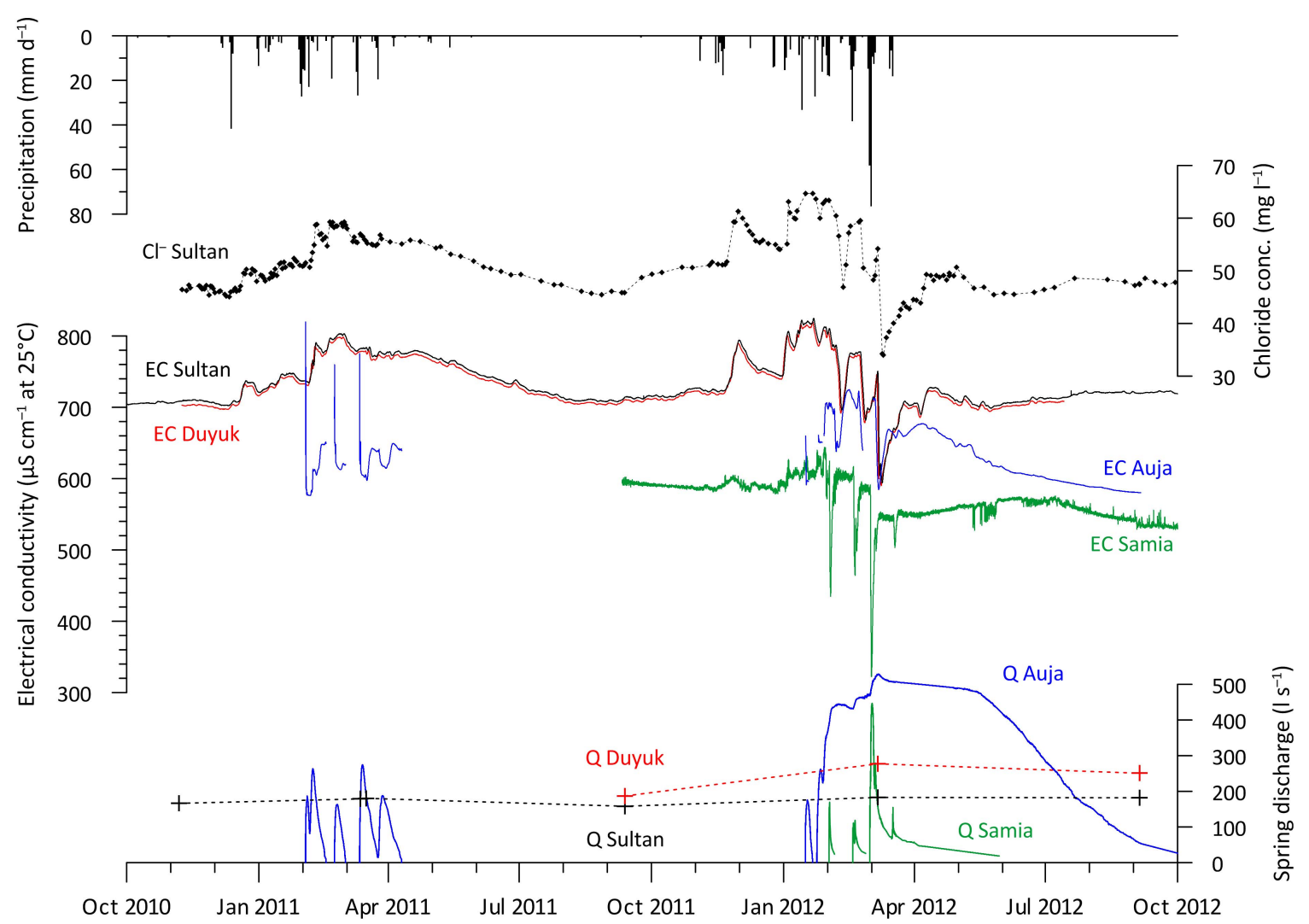

Figure 5.3: Time series of precipitation (gauging station Kafr Malik), chloride concentration, specific electrical conductivity, and discharge of the four monitored springs during the hydrological years of 2011 and 2012.

\section{Characteristics of the Samia spring system}

The monitoring conducted during the study allowed for the first time the assessment of the discharge behaviour of the Samia spring since the infrequent measurements of the 1950s (Rofe \& Raffety Consulting Engineers, 1963) before active management of the spring aquifer started in 1964/1965. In the dry year of 2011, because of abstraction, only a very short spring flow period of about $9 \mathrm{~h}$ was observed. In contrast, during the above average hydrological year of 2012 considerable discharge amounts were assessed (Table 5.3). Accordingly, it is expected that during pluvial periods the spring discharge volume is considerably higher than the abstraction quantity (Table 5.1).

The spring displays typical karst spring discharge behaviour, characterised by pronounced peaks and a rapid recession after recharge events (Fig. 5.4). In contrast, the three larger springs Auja, Sultan and Duyuk are characterised by a conduit restricted flow mechanism, i.e. exhibiting a prominent plateau in discharge (Schmidt et al., 2014). The electrical conductivity signal measured in the well is influenced by the pumping abstraction during certain periods (Figs. 5.3 and 5.4). During exploration well drilling for the spring's aquifer, an overlying aquifer was tapped (Rofe \& Raffety Consulting Engineers, 1963). Therefore, it is expected that the changing hydraulic head in the well due to abstraction (observed range $>40 \mathrm{~m}$ ) are inducing a variable mixing of different sub-aquifers. 
Evaluation of rapid recharge processes and spring source vulnerability

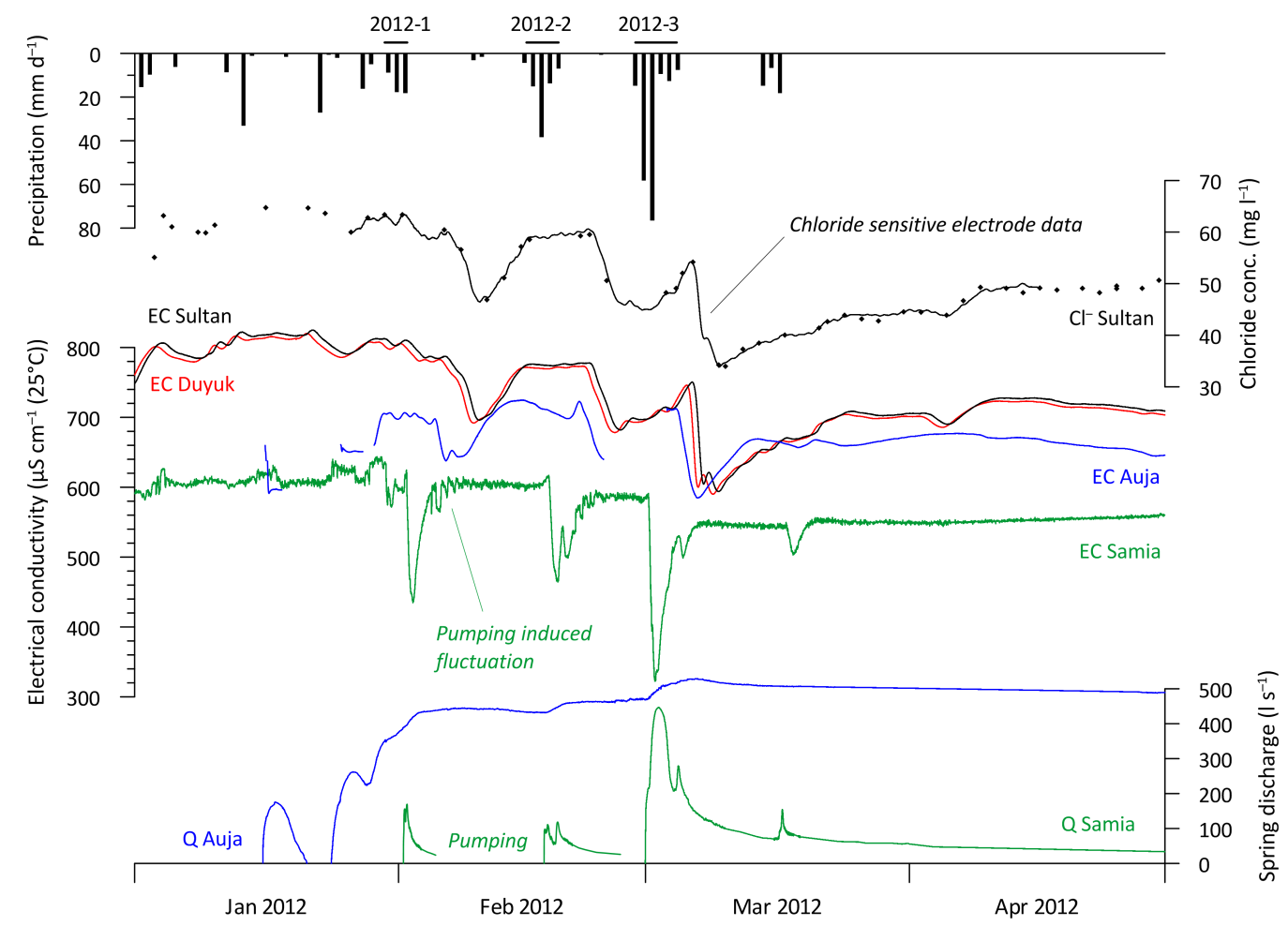

Figure 5.4: Close-up of the high-resolution time series for the recharge events of the winter season 2011/2012.

\subsubsection{Correlation between specific electrical conductivity and chloride concentration}

In karst groundwater the bulk contribution to electrical conductivity is usually attributed to the ions $\mathrm{Ca}^{2+}, \mathrm{Mg}^{2+}$, and $\mathrm{HCO}_{3}{ }^{-}$(e.g. Krawczyk and Ford, 2006). Despite the expected low relative contribution of $\mathrm{Na}^{+}$and $\mathrm{Cl}^{-}$to electrical conductivity for the regional groundwater, $\mathrm{EC}$ and chloride concentration showed a remarkable correlation for the four sampled springs (Fig. 5.5).

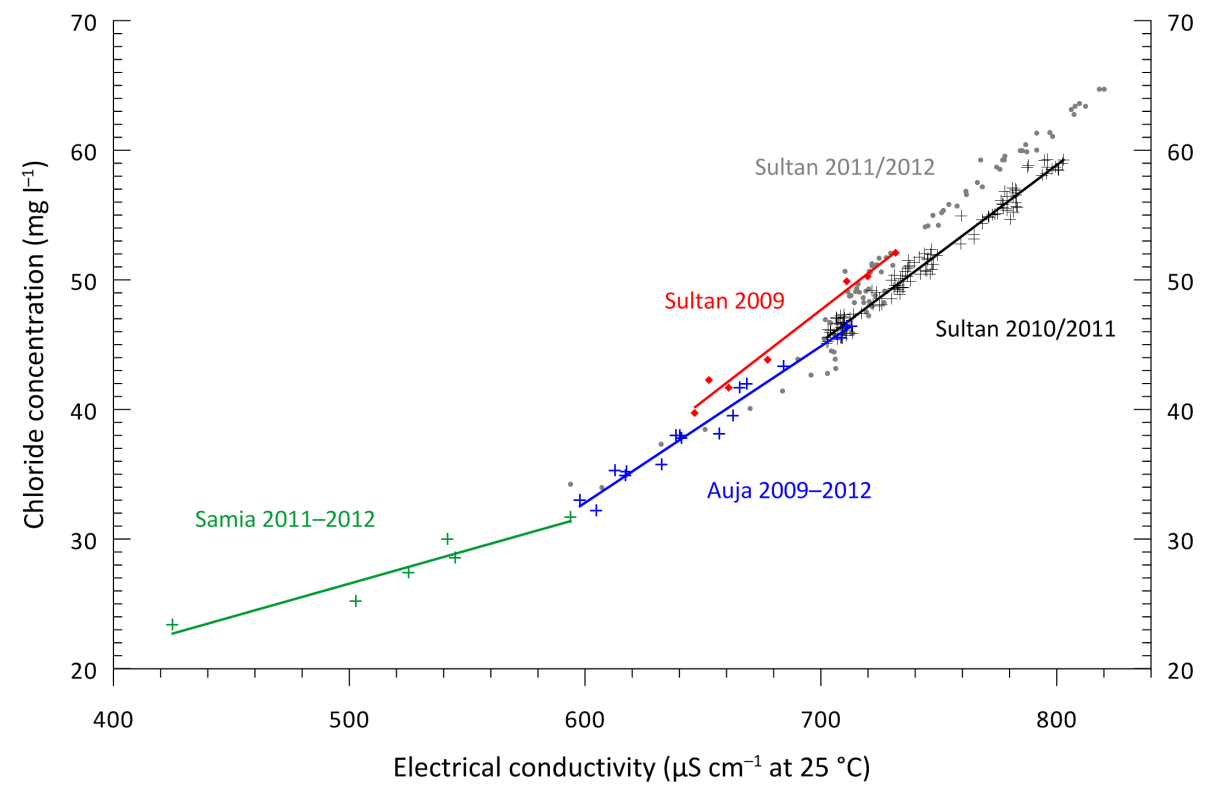

Figure 5.5: Correlation between specific electrical conductivity and chloride concentration in spring water. 
For Auja spring a stable correlation was observed during the hydrological years 2009-2012, however based on limited data. For Sultan spring, differences between the individual winter seasons and also a non-linearity during event breakthroughs was observed. Therefore, for the calculations for Sultan spring either the chloride data assessed by the chloride sensitive electrode in combination with manual sampling or specific event/annual $\mathrm{EC}-\mathrm{Cl}^{-}$-correlations were used.

\subsubsection{Estimation of the variable fraction of the wastewater-borne discharge component}

\section{Sultan-Duyuk system}

The natural background chloride concentration of Sultan spring was determined at $22.5 \mathrm{mg} \mathrm{l}^{-1}$ by Schmidt et al. (2013), evaluating data for the period of 1938 to 1940 (Fig. 5.6). Due to anthropogenic impacts, chloride concentration displayed a rising trend during the second half of the 20th century (Schmidt et al., 2013). The measured chloride concentration during 2010-2013 varied between 27 and $65 \mathrm{mg} \mathrm{l}^{-1}$ (Fig. 5.3). A current background level during summer and autumn of about $45 \mathrm{mg} \mathrm{l}^{-1}$ is observed, corresponding to electrical conductivity values of about $700 \mu \mathrm{S} \mathrm{cm}^{-1}$. This chloride concentration is already twice the natural background concentration (NBC). During winter and spring, values are considerably higher, reaching up to $65 \mathrm{mg} \mathrm{l}^{-1}$, corresponding to electrical conductivity values exceeding $800 \mu \mathrm{sm}^{-1}$. Such annual chloride fluctuation could in principle be explained by the following mechanism (Ford and Williams, 2007): (1) a concentration of chloride in the soil water during the dry summer season by evapotranspiration and (2) a flushing of this residual high concentration water from the soil into the saturated zone by the precipitation events of the winter season. However, this kind of behaviour is not observed in the historical time series (Fig. 5.6).

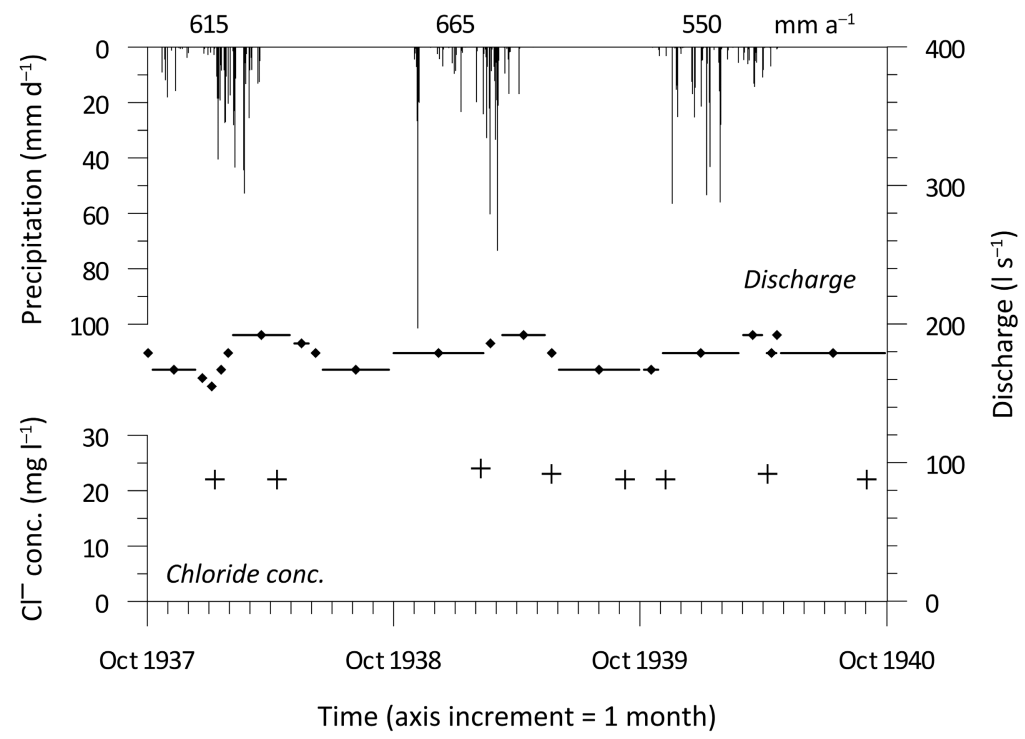

Figure 5.6: Sultan spring discharge and chloride concentration during the hydrological years of 1938-1940 along with daily and annual precipitation data for Jerusalem (gauging station St. Anne).

In contrast, the infiltration of wastewater via leaky sewer systems, cesspits, and wastewater discharge to ephemeral valleys is strongly assumed to constitute the main source of the observed excess chloride (Schmidt et al., 2013). The expected average chloride concentration in wastewater 
in the region is ca. $300 \mathrm{mg} \mathrm{l}^{-1}$ (Schmidt et al., 2013). With this end-member concentration, the time variable fraction of total present wastewater (based on the natural background concentration) and the fraction of "new" wastewater (based on the current background level) present in the water of Sultan spring were calculated (Eq. (5.2); Fig. 5.7). The following conceptual model of flow and transport in the aquifer system is proposed (the numbers refer to time periods in Fig. 5.7):

(1a) During the dry summer season, infiltrating wastewater is stored in the subsurface close to the infiltration location, i.e. in the epikarst, vadose zone, and perched groundwater horizons. Spring discharge is mainly constituted by flow out of the bulk groundwater storage, which displays an chloride concentration of about $45 \mathrm{mg} \mathrm{l}^{-1}$.

(1b) Towards the end of the summer and in autumn, often a slight increase in EC and chloride concentration is observed, presumably due to a commencing breakthrough of the ongoing wastewater infiltration, i.e. the exceedance of the near-surface storage compartments in the system.

(2a) The precipitation events of the winter season impose a high hydraulic load on the system. Recharge water mobilises the "stored" wastewater by a piston type flow mechanism. Therefore, the first recharge events of the winter season lead to a considerable increase of chloride concentration at the spring.

(2b) For certain recharge events, usually during the mid-winter, the chloride concentration at the spring is not modified and remains at relatively high levels. For those events, a mixture of event water stemming from precipitation and wastewater is assumed, the mixture displaying a chloride concentration similar to the pre-event water.

(2c) Large recharge events, which are usually taking place in mid/late winter, lead to massive breakthroughs of event water at the springs cosiderably lowering chloride concentration.

(3) After the main recharge events for the season, chloride concentration is usually decreasing towards the summer season. For example, in spring/summer 2011 chloride concentration decreased by $10 \mathrm{mg} \mathrm{l}^{-1}$ during about 4.5 months (Fig. 5.3). The decrease can be explained by the successive flushing of the wastewater component by the "fresh" recharge water from storage compartments (e.g. the epikarst) towards the saturated zone and spring.

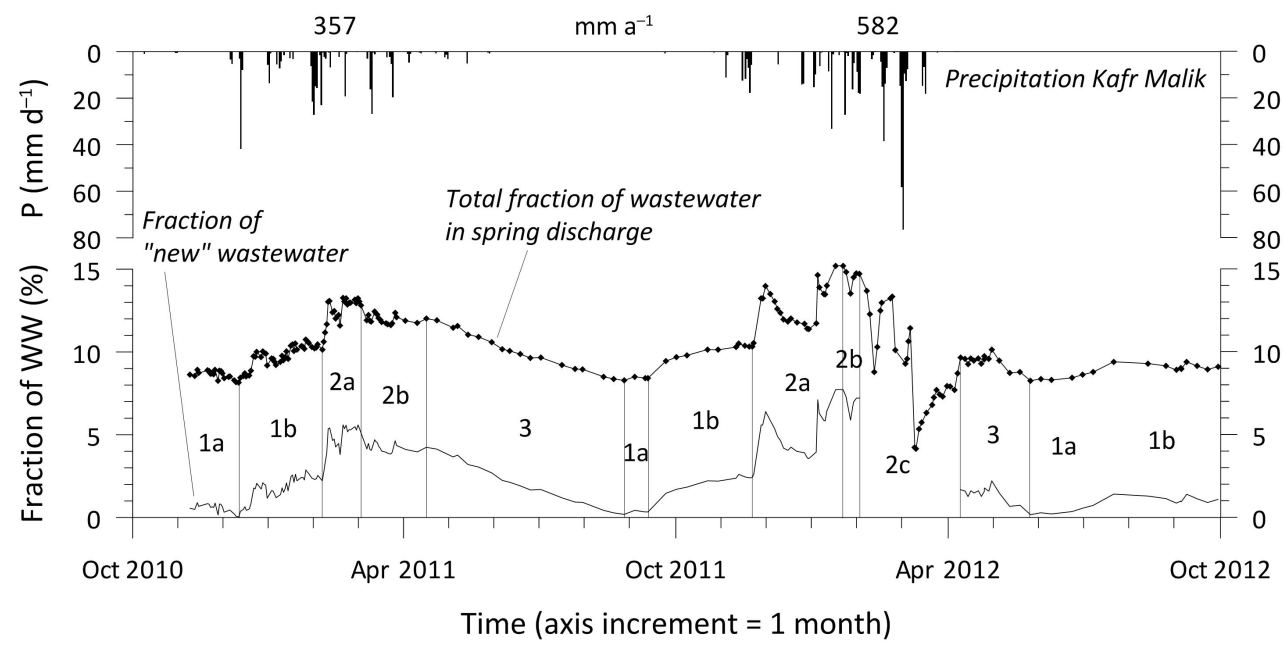

Figure 5.7: Calculated wastewater-borne flow fraction at the Sultan spring. 


\section{Auja spring}

For the Auja spring a similar behaviour was observed. However, due to the frequent drying up of the spring and a high variability in discharge, the behaviour is more complex. During the summer season, the electrical conductivity of the spring water decreases with decreasing spring discharge. A possible explanation for this phenomenon is a larger relative admixture of noncontaminated groundwater expected to be characterised by a longer residence time. Rosenthal and Kronfeld (1982) considered the possibility of an admixture of groundwater from deeper aquifer layers at the Auja spring based on uranium isotope ratios.

\section{Samia spring}

Compared to the springs Sultan and Auja, only a small "mound" with higher electrical conductivity is recognised during the winter season (Fig. 5.3). This is attributed to a relatively rural catchment area. Apart from the very pronounced event breakthroughs, an electrical conductivity "trough" is observed from about March until June 2012 (Fig. 5.3). This might be attributed to the arrival of freshly recharged water displaying an intermediate residence time.

\subsubsection{Implications of the precipitation input signal measurements}

The monitored precipitation events often displayed an early phase of low intensity. For the lag time calculations, the time of the intensive event onset $\left(t p_{0}\right)$ was used instead of $t p_{\text {onset }}$ (compare Fig. 5.2). The onset of intensive precipitation events is uniform over the recharge area of the aquifer system. For example, tponset is registered with a median time lag of only 13 minutes $(n=13$ events) at gauging station Mughayyir compared to station Sinjil, which is located 8 kilometres to the west (upwind direction). Kafr Malik gauging station is expected to be located close to the recharge area of all monitored springs and was used for all lag time calculations of spring events.

The chloride concentration of precipitation was very similar for the stations Ramallah and Taybeh. Even for station Jericho, located already considerably east of the recharge area and receiving only about $20 \%$ of the precipitation amount compared to the highland area, only slightly increased concentrations were measured. For the calculations of the event water fraction $F_{p}$, the data of station Ramallah were used due to their higher temporal resolution.

\subsubsection{Estimated volumes of the conduit systems}

The mean lag time method estimate for the conduit system of the Auja spring is ca. $140000 \mathrm{~m}^{3}(n=5$, range: 130000-150000 $\mathrm{m}^{3}$, Table 5.3). As discharge for the Sultan and Duyuk springs was not monitored in a high time resolution and the turbidity sensor at Sultan spring only worked until autumn 2009, only one to of $0.8 \mathrm{~d}$ could be observed (event 2009). For this event, the transport lag time $t_{0}-t_{1}$ was calculated to $5 \mathrm{~d}$. Corrected by the $0.7 \mathrm{~d}$ time lag between the Duyuk and Sultan springs (Section 5.4.1) and multiplied by the mean discharge of both springs (ca. $0.44 \mathrm{~m}^{3} \mathrm{~s}^{-1}$, Table 5.1), a conduit volume of ca. $170000 \mathrm{~m}^{3}$ was estimated for the karst system upstream of Duyuk spring. A conduit volume of about $10000 \mathrm{~m}^{3}$ between Duyuk and Sultan spring could be 
approximated by multiplying the electrical conductivity signal lag $(0.7 \mathrm{~d})$ and the mean discharge of the Sultan spring $\left(0.18 \mathrm{~m}^{3} \mathrm{~s}^{-1}\right)$. Hence, the combined volume for the Sultan/Duyuk conduit system is about $180000 \mathrm{~m}^{3}$. At the smaller Samia spring the well-defined events 2012-1 and 2012-2 yielded a conduit volume of ca. $6000 \mathrm{~m}^{3}$ (ca. $4500-4900 \mathrm{~m}^{3}$ from spring discharge onset plus an estimated quantity of $1200-1800 \mathrm{~m}^{3}$ before spring onset).

The values obtained by the lag time method reflect only the fractions of the conduit system volume participating in rapid transport. Hydraulically connected highly permeable sections like other large karst voids are not included. Furthermore, Birk et al. (2006) found by numerical modelling studies that the calculated conduit volume dependents on the transient matrix-conduit exchange in the aquifer. In their model with a conduit system draining the fractured rock matrix, the lag time method estimated values are considered over-estimated because of matrix-conduit crossflow. Therefore, they recommended to use the largest conduit system recharge events for the estimation which were accordingly characterised by the least matrix-conduit cross-flow. However, if a considerable flow from the conduit system into the fractured matrix is present, as was assumed during recharge events at the Auja spring (Schmidt et al., 2014), the conduit volume might be underestimated.

\subsubsection{Source vulnerability evaluation for the investigated springs}

The large recharge events, which caused a distinct response in physicochemical parameters at all monitored springs, were analysed and the results are documented in Tables 5.3 and 5.4 and Fig. 5.8. The three operative questions from Section 5.1 are answered subsequently:

Question 1 (time lag): Since spring discharge is relatively stable for the Sultan/Duyuk system and during high flow periods also for the Auja spring, the time lag for event water to reach the spring after precipitation events is quite uniform and can be well predicted (Tables 5.3 and 5.4). It ranges from about 1 day for the Samia spring to about 6 days for the Sultan spring. The estimated conduit system volumes (Section 5.4.4) can be used to calculate the time lag for other than the usually observed discharge values, for example for lower discharges at the Auja spring.

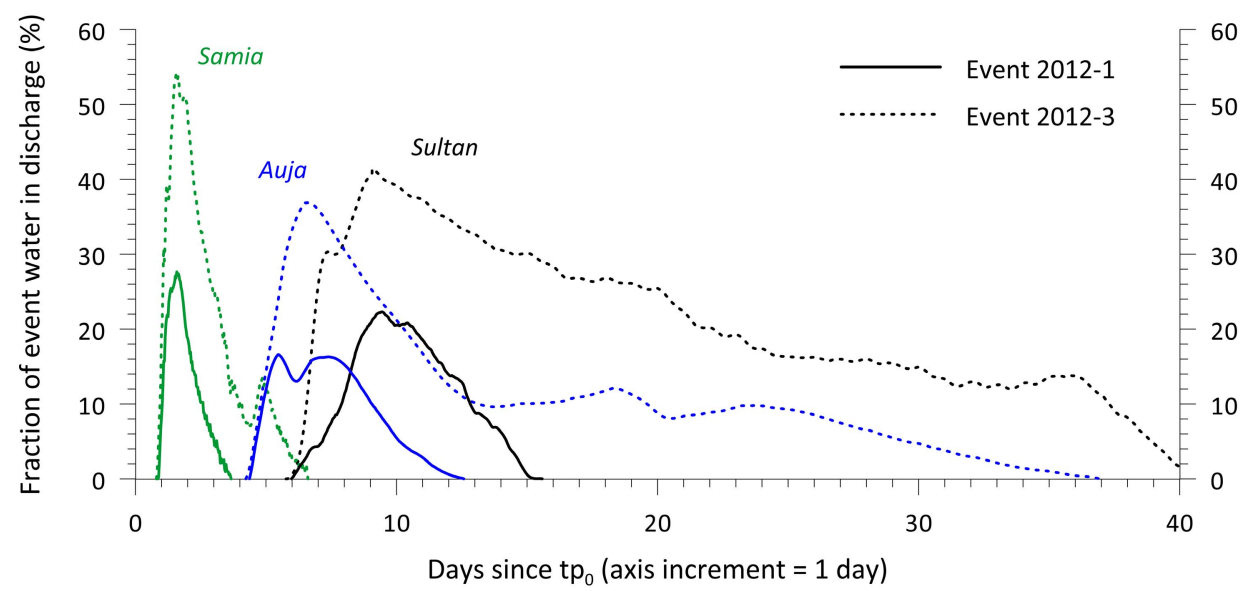

Figure 5.8: Comparison of the event water fractions observed at the springs, at the example of the recharge events 2012-1 and 2012-3 (Samia and Auja time series based on electrical conductivity data converted to chloride concentration, Sultan time series based on corrected chloride sensitive electrode data with an moving average filter of $0.5 \mathrm{~d}$ filter width applied). 
Table 5.3: Compilation and comparison of the large precipitation event signals monitored at precipitation gauging station Kafr Malik and the four springs.

\begin{tabular}{|c|c|c|c|c|c|c|c|c|c|c|c|c|c|c|c|c|c|c|c|c|}
\hline $\begin{array}{l}\text { Storm } \\
\text { (No.) }\end{array}$ & Date & $\begin{array}{l}\text { Break }^{a} \\
\text { (d) }\end{array}$ & $\begin{array}{l}t^{t} p_{\text {onset }} \\
\text { (d) }\end{array}$ & $\begin{array}{l}\text { tpo } \\
\text { (d) }\end{array}$ & $\begin{array}{l}t p_{m} \\
\text { (d) }\end{array}$ & $\begin{array}{c}P \\
(\mathrm{~mm})\end{array}$ & Spring & $\begin{array}{c}t_{0} \\
\text { (d) }\end{array}$ & $\begin{array}{c}t_{1} \\
\text { (d) }\end{array}$ & $\begin{array}{l}t_{2} \\
\text { (d) }\end{array}$ & $\begin{array}{c}t_{3} \\
\text { (d) }\end{array}$ & $\begin{array}{l}t_{m} \\
\text { (d) }\end{array}$ & $\begin{array}{l}t_{3}-t_{1} \\
\text { (d) }\end{array}$ & $\begin{array}{l}M_{\text {RT }} \\
\text { (d) }\end{array}$ & $\begin{array}{c}V_{c} \\
\left(\mathrm{~m}^{3}\right)\end{array}$ & $\begin{array}{c}\mathrm{Cl}^{-} P \\
\left(\mathrm{mg} \mathrm{l}^{-1}\right)\end{array}$ & $\begin{array}{c}F_{P \max }{ }^{b} \\
(\%)\end{array}$ & $\begin{array}{c}F_{\text {Pmean }^{\mathrm{b}}} \\
(\%)\end{array}$ & $\begin{array}{c}F P^{\mathrm{b}} \\
\left(\mathrm{m}^{3}\right)\end{array}$ & $\begin{array}{c}Q_{\text {event }^{\mathrm{c}}} \\
\left(\mathrm{m}^{3}\right)\end{array}$ \\
\hline \multirow[t]{2}{*}{2009} & $27.02-03.03$ & 4 & -0.16 & 0 & 0.74 & 149 & Auja & 0.65 & 4.5 & 7.3 & 15 & 8.3 & 10 & 7.5 & 140000 & - & 31 & 17 & 71000 & - \\
\hline & & & & & & & Sultan & $0.78^{\mathrm{d}}$ & 5.8 & 10 & 21 & 12 & 15 & 12 & 180000 & & 36 & 19 & 43000 & - \\
\hline \multirow[t]{2}{*}{2010} & $25.02-01.03$ & 20 & -0.23 & 0 & 1.19 & 149 & Auja & 0.58 & 5.7 & 8.1 & 17 & 8.8 & 12 & 7.6 & 140000 & - & 28 & 11 & 52000 & - \\
\hline & & & & & & & Sultan & - & 6.2 & 9.7 & - & - & - & - & - & & $\sim 40$ & & $\sim 60000$ & - \\
\hline \multirow[t]{4}{*}{2011} & $29.01-01.02$ & 20 & -0.99 & 0 & 0.43 & 86 & Samia & 2.66 & - & - & - & - & - & - & - & 6.3 & - & - & - & - \\
\hline & & & & & & & Auja & 3.41 & - & - & - & - & - & - & - & & - & - & - & - \\
\hline & & & & & & & Duyuk & - & 5.1 & - & - & - & - & - & - & & - & - & - & - \\
\hline & & & & & & & Sultan & - & 5.8 & - & - & - & - & - & - & & - & - & - & - \\
\hline \multirow[t]{4}{*}{$2012-1$} & $30.01-01.02$ & 2 & -1.74 & 0 & 0.13 & 45 & Samia & 0.32 & 0.9 & 1.6 & 3.7 & 1.6 & 2.8 & 1.4 & 6300 & 1.6 & 28 & 14 & 2100 & 25000 \\
\hline & & & & & & & Auja & $0.58^{\mathrm{d}}$ & 4.2 & 5.5 & 14 & 7.3 & 9.5 & 7.2 & 130000 & & 17 & 9 & 29000 & - \\
\hline & & & & & & & Duyuk & - & 4.7 & 8.7 & 15 & - & 10 & - & - & & - & - & - & - \\
\hline & & & & & & & Sultan & - & 5.4 & 9.4 & 15 & 10 & 10 & 10 & - & & 22 & 11 & 17000 & - \\
\hline \multirow{4}{*}{$2012-2$} & $16.02-19.02$ & 14 & $\begin{array}{l}-1.57 \\
\end{array}$ & 0 & 0.17 & 79 & Samia & 0.37 & 1.1 & 2.1 & 5.1 & 2.4 & 4.0 & 2.2 & 6000 & 10.2 & 33 & 19 & 4200 & 68000 \\
\hline & & & & & & & Auja & 0.73 & 4.6 & - & - & - & - & - & 150000 & & - & - & - & - \\
\hline & & & & & & & Duyuk & - & 5.1 & 8.8 & 17 & - & 12 & - & - & & - & - & - & - \\
\hline & & & & & & & Sultan & - & 5.8 & 9.5 & 18 & 12 & 12 & 12 & - & & 26 & 17 & 30000 & - \\
\hline \multirow[t]{4}{*}{$2012-3$} & $28.02-04.03$ & 9 & -0.74 & 0 & 0.85 & 179 & Samia & 0.30 & 0.8 & 1.6 & 6.9 & 2.1 & 6.1 & 1.2 & (7700) & 5.6 & 54 & 25 & 36000 & 550000 \\
\hline & & & & & & & Auja & 0.50 & 4.0 & 6.6 & 37 & 12 & 33 & 11 & 150000 & & 37 & 11 & 160000 & - \\
\hline & & & & & & & Duyuk & - & 5.3 & 8.4 & - & - & - & - & - & & - & - & - & - \\
\hline & & & & & & & Sultan & - & 5.9 & 9.0 & 42 & 17 & 36 & 17 & - & & 41 & 20 & 110000 & - \\
\hline \multirow[t]{3}{*}{$2013-1$} & 05.01-10.01 & 14 & -0.59 & 0 & 2.37 & 179 & Samia & (1.91) & 2.6 & 3.1 & 5.9 & 3.7 & 3.4 & 1.3 & - & 7.0 & 58 & 39 & 38000 & - \\
\hline & & & & & & & Auja & $(0.25)$ & 5.8 & 8.0 & - & - & - & - & - & & & - & - & - \\
\hline & & & & & & & Sultan & - & 7.3 & 10 & 30 & 15 & 23 & 12 & - & & 55 & 28 & 95000 & - \\
\hline \multirow[t]{3}{*}{$2013-2$} & $30.01-01.02$ & 20 & -0.31 & 0 & 0.44 & 112 & SamiaA & 0.45 & 0.5 & 0.6 & 0.7 & 0.55 & 0.2 & 0.1 & (few100) & 2.2 & $\sim 67$ & 22 & 310 & - \\
\hline & & & & & & & SamiaB & 0.45 & 1.0 & 1.4 & - & - & - & - & $(7900)$ & & - & - & - & - \\
\hline & & & & & & & Sultan & - & 5.1 & 9.9 & 31 & 14 & 26 & 13 & - & & 35 & 14 & 58000 & - \\
\hline
\end{tabular}

- Not determined (not calculated, probe malfunction, parameter not measured, "positive" electrical conductivity signal response for the event 2011, etc.).

a Days without precipitation before tponset (a few small events up to a total amount of $5 \mathrm{~mm}$ were neglected).

${ }^{\mathrm{b}}$ Calculated fraction/amount of event water. For 2009 and 2010 values are an approximation because the mean precipitation weighted chloride concentration of the large events (5.8 mg $1^{-1}$ ) was used for calculation (values in italics). A probe malfunction occurred during the event 2010 at Sultan spring and the late part of the event breakthrough was reconstructed (mean value of envelope used).

c Spring discharge due to recharge event calculated for the Samia spring. Hydrographs were corrected for pumping abstraction. The late (fully pumped) baseflow recession periods were approximated by employing the recession coefficients derived from the preceding baseflow periods.

d Determined by onset of the autochthonous turbidity signal. 
Question 2 (event water fraction): It can be assumed that the dispersion of the fast flow component increases with increasing transport distance and conduit volume. Consequently, the maximum event water fraction was usually higher for the Samia spring compared to the springs Auja and Sultan (Table 5.3, Fig. 5.8) and reached peak values of more than 50\%. However, for the Samia spring for the massive event breakthroughs the validity of the extrapolated linear equation to convert electrical conductivity to chloride concentration can be questioned. Furthermore, because the relative fraction of the fast flow component was assessed by employing the tracer chloride or its proxy electrical conductivity, especially for the large springs a possible contribution of wastewater simultaneously flushed during the breakthrough events may decrease the obtained value. The Samia spring is expected to be least influenced by wastewater infiltration, whereas for the heavily influenced springs (e.g. Sultan) the calculated percentages are assumed to constitute minimum values.

Question 3 (duration of breakthrough): For medium size recharge events (e.g. 2012-1), the length of the breakthrough increases from about 3-4 days for the Samia system, to about 10 days for the Auja system to 10-15 days for the Sultan/Duyuk system. After events characterised by a very high recharge amount (2012-3, and to a lesser extend also both large events of 2013), the duration of the breakthrough at the springs Auja and Sultan/Duyuk can exceed one month.

Table 5.4: Summary of the spring characteristics based on Table 5.3. Extended range for large breakthrough events (e.g. event No. 2012-3) in brackets; values based on limited data in italics.

\begin{tabular}{|c|c|c|c|c|c|c|c|c|c|c|}
\hline \multirow[t]{2}{*}{ Spring } & \multirow{2}{*}{$\begin{array}{l}\text { Conduit } \\
\text { volume } \\
\left(\mathrm{m}^{3}\right)\end{array}$} & \multicolumn{2}{|c|}{ Typical lag times } & \multirow{2}{*}{$\begin{array}{l}\text { Breakthr. } \\
\text { duration } \\
\text { (d) }\end{array}$} & \multirow{2}{*}{$\begin{array}{c}\text { MRT } \\
\text { fast flow } \\
\text { (d) }\end{array}$} & \multicolumn{5}{|c|}{ Event characteristics 2012 (3 storms) $)^{\mathrm{a}}$} \\
\hline & & $\begin{array}{l}\text { hydraul. } \\
\text { (d) }\end{array}$ & $\begin{array}{c}\text { transport } \\
\text { (d) }\end{array}$ & & & $\begin{array}{c}F_{P \max } \\
(\%)\end{array}$ & $\begin{array}{c}F_{P \text { mean }} \\
(\%)\end{array}$ & $\begin{array}{l}F_{P} \\
(\mathrm{Mi}\end{array}$ & $\begin{array}{l}Q_{2012} \\
\left.\mathrm{~m}^{3}\right)\end{array}$ & $\begin{array}{l}F_{P} \\
(\%)\end{array}$ \\
\hline Samia & 6000 & 0.3 & 1 & $3-6$ & $1-2$ & $28-54$ & $14-25$ & 0.042 & 0.64 & 7 \\
\hline Auja & 140000 & 0.7 & $4-5$ & $10(-30)$ & $7.5(-11)$ & $17-37$ & $9-11$ & 0.24 & 7.2 & 3 \\
\hline Duyuk & 170000 & & 5 & & & & & & & \\
\hline Sultan & $180000^{\mathrm{b}}$ & 0.8 & 6 & $10-15(-40)$ & $12(-17)$ & $22-41$ & $11-20$ & 0.16 & 5.7 & 3 \\
\hline
\end{tabular}

${ }^{a} Q_{2012}$ refers to: Samia: observed reconstructed spring discharge during 2012, the total recharged value is expected to be higher due to unaccounted pumping abstraction (e.g. during January 2012); Auja: Measured spring discharge during 2012 (see further Schmidt et al., 2014); Sultan: based on the mean discharge value of $1801 \mathrm{~s} \mathrm{~s}^{-1}$ (discharge measurements in 2012: 06. March: $1831 \mathrm{~s}^{-1}$, 04. September: $\left.1821 \mathrm{~s}^{-1}\right)$.

${ }^{\mathrm{b}}$ The value includes the estimated karst conduit system volume of ca. $170000 \mathrm{~m}^{3}$ upstream of Duyuk spring.

Because the fast flow component of large recharge events often is characterised by an elevated turbidity, it is unsuitable for water supply. The presence of bacteria, viruses and selected chemical constituents still has to be determined for the fast flow component. Therefore, it is unclear if the fast flow component is chemically of inferior quality compared to the water discharging during conditions of lower aquifer dynamics. As the residence time of the fast flow component was assessed by the conservative tracer chloride or its proxy electrical conductivity, it must be taken into account that in karst systems particles and bacteria may be transported faster than the solutes due to exclusion processes (e.g. Pronk et al., 2006; Göppert and Goldscheider, 2008). Based on the chemograph measurements, it is postulated that the spring water quality of the Sultan/Duyuk system is generally "best" during the summer season (period "1a" in Fig. 5.7). Towards the end of the summer season, significant precipitation events already mobilise wastewater stored in the system. 
From a practical perspective, the operative ability to shut off specific water sources in case of (expected) contamination depends on the availability of alternative sources and the buffer capacity of the supply system. In case of the Samia well (tapping the karst aquifer), four wells nearby abstract water from deeper aquifer sections (predominantly Albian aquifer layers). Those wells can provide suitable drinking water during periods of abstraction stoppage. In contrast, in the case of the Sultan spring - where duration of breakthrough events is about 10-40 days-shut down is not feasible. Since alternative sources of water are not available, maximum shut down time is around 12 hours (personal communication, Eng. J. Bsharrat, Jericho Municipality).

\subsubsection{Determination of the groundwater recharge processes}

The hydraulic response of the springs to precipitation events is rapid. The lag time tpo-to for precipitation events with a sharp onset was about $0.3 \mathrm{~d}$ for the Samia spring and about $0.7 \mathrm{~d}$ for the Auja spring, respectively (also additional smaller events complementary to Table 5.3 were analysed). For the Sultan/Duyuk system a lag time of less than one day can be expected as well, for example a lag of $0.8 \mathrm{~d}$ was determined for the event of 2009. Also peak spring discharge is reached with a short time lag after the recharge events, e.g. 0.6-2 days after tpo for the Samia spring for the events of 2012. These rapid responses clearly direct to a focussed recharge mechanism, either from subcutaneous flow concentration in the epikarst (Gunn, 1983; Williams, 1983) or from focussed infiltration of wadi runoff. In order to determine if the recharge can be stemming from wadi runoff, (1) the occurrence and timing of wadi runoff and (2) the turbidity signals recorded at the springs were evaluated:

(1) The three large breakthrough events of 2012 largely display similar shapes (Fig. 5.4) and time lags (Table 5.3, Fig. 5.8), although only for the third event larger amounts of wadi runoff were observed (Ries, 2013). Because of the short time lags and clear signals, the monitoring data for spring responses and wadi runoff (surface catchment area of $14.5 \mathrm{~km}^{2}$ upstream of Samia spring) measured at Samia spring were especially instructive regarding the determination of recharge processes in the study area. As an example, the event 2012-2 with a precipitation sum of $79 \mathrm{~mm}$ during 3.8 days at Kafr Malik gauging station is discussed in detail. It consisted of three distinct sub-events (Fig. 5.9). The first sub-event did not generate responses and is expected to replenish the soil moisture deficit because of a preceding two-week period with negligible precipitation. Sub-event No. 2, furthermore characterised by a very sharp and heavy onset ( $20 \mathrm{~mm}$ in 4 hours) did not generate wadi runoff either but led to distinct spring responses. Sub-event No. 3 caused a small amount of wadi runoff, presumably due to a soil saturation mechanism (Ries, 2013) and in parallel led to a second breakthrough of freshly recharged water at the spring, merging with the first breakthrough. Those rapid and uniform spring responses regardless of surface runoff taking place indicate that wadi runoff is not significant in the generation of rapid recharge and spring responses.

(2) Wadi runoff in the study area was visually observed to display a high turbidity, probably due to the suspension of residual clays and iron oxides. At the Auja spring allochthonous turbidity signals reaching up to 40 NTU were observed due to the large events only (except for the event 2011). At the Sultan spring during the large event 2009, a small allochthonous peak superimposed on the autochthonous turbidity signal with a total value of about 10 NTU was measured. In 
contrast, semi-arid karst spring systems partly fed by concentrated infiltration of surface runoff were observed to display a turbidity of up to several hundred NTU (e.g. Amraoui et al., 2003). This relative lack of allochthonous turbidity is regarded as evidence that the recharge contribution of wadi runoff is not extensive. However, also a possible temporal storage of particles in the aquifer system has to be taken into account, maybe even some sort of sinkmechanism.

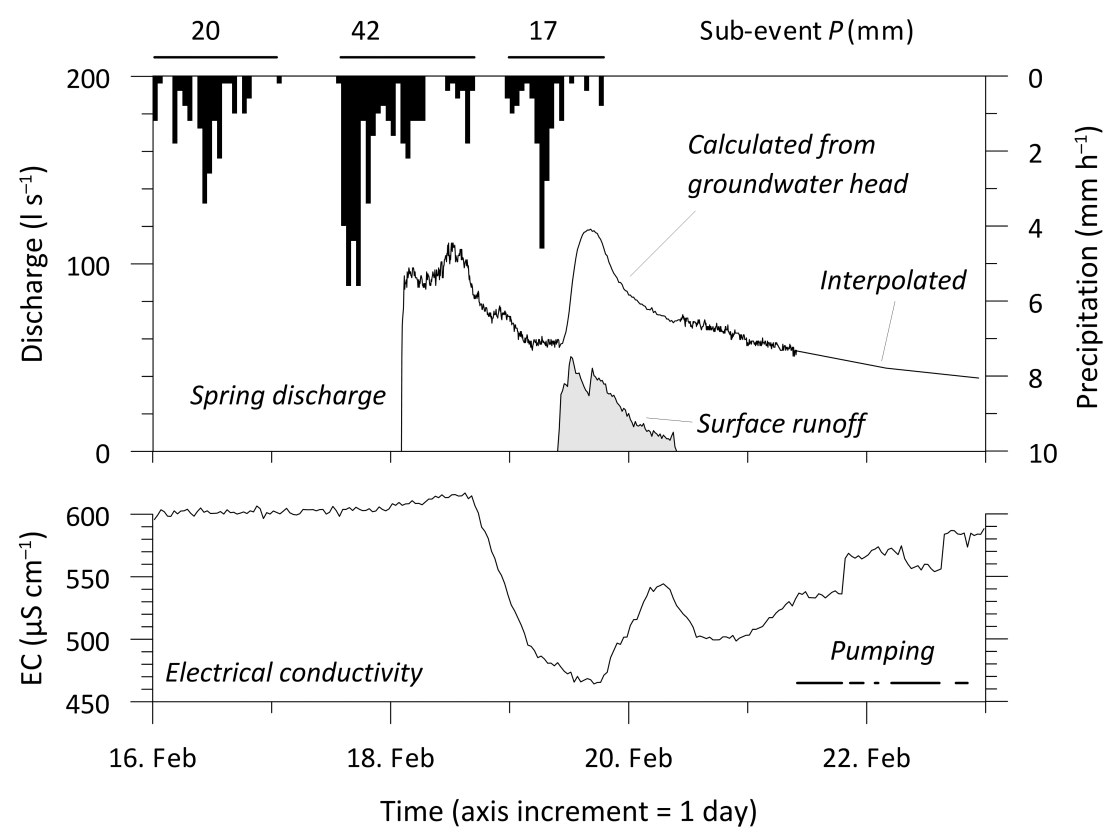

Figure 5.9: Recharge event 2012-2 monitored at Samia spring and precipitation gauging station Kafr Malik.

If recharge due to wadi runoff is taking place, it is not expected to happen close to the spring, because of the extended lag times $t_{0}-t_{1}$ for the larger spring systems (Auja ca. $4-5 \mathrm{~d}$; Sultan ca. $6 \mathrm{~d})$ also during events when extensive surface runoff quantities were observed. An exception is a very rapid breakthrough during the event 2013-2 at Samia spring (Samia A, Table 5.3). At gauging station Kafr Malik, assumed to be located in the spring recharge area, particularly high precipitation intensity was measured ( $35 \mathrm{~mm}$ during $9 \mathrm{~h}$ plus $32 \mathrm{~mm}$ during the next $3 \mathrm{~h}$ ). Just one hour after the onset of both surface runoff and a rise of groundwater head (to), a pulse of fast event water was observed at the spring, lowering conductivity from the pre-event value of ca. 500 $\mu \mathrm{S} \mathrm{cm} \mathrm{cm}^{-1}$ to less than $200 \mu \mathrm{S} \mathrm{cm}-1$ and recovering quickly without almost any tailing. A similar behaviour was not observed during the event 2012-3, also characterised by a large surface runoff amount before the onset of spring discharge. Therefore, the first breakthrough of 2013-2 is attributed to the local infiltration of surface runoff at an unknown location close to the spring. During the second spring-breakthrough of this event spring water turbidity probably exceeding 100 NTU was visually observed.

As closed depressions are only present in a small part of the study area (Fig. 5.1), the focussing of infiltrated water is expected to happen throughout the epikarst. Ford and Williams (2007) expect percolation through the fractured matrix, which is generally assumed to be relevant in many humid temperate climate zone karst aquifers (e.g. Geyer, 2008), to be less significant in semi-arid karst aquifers. Lange et al. (2010) indeed found by cave drip studies for a similar site of the Eastern Mediterranean karst region that percolation through the bulk vadose zone is probably 
insignificant compared to the focussed flow along preferential pathways. Furthermore, Schmidt et al. (2014) found by mathematical modelling of the hydraulic spring responses to recharge events of the Auja spring that the recharge is probably to a great extend occurring in the high permeability parts of the aquifer system.

Whereas the reaction of the hydraulic signal after recharge events is fast, the assessed fractions of fast event water (Section 5.4.6) are small compared to the overall recharge values. This is attributed to mixing processes in the aquifer and a comparatively weak transport connection of most locations of focussed recharge to the main conduit system. These connections might be enhanced during large recharge events because of high groundwater heads. For example, the event 2012-3 was characterised by an extended breakthrough of event water at the Sultan and Auja springs (Fig. 5.8). For the quantitative assessment of the different forms of groundwater recharge, spring measurements alone are not sufficient but should be combined with unsaturated zone studies (e.g. Arbel et al., 2010; Lange et al., 2010).

\subsection{Conclusions and outlook}

High-resolution monitoring of four springs as well as the precipitation input signal of a karst aquifer in a region with distinct semi-arid climate was conducted during a period of five years, covering different hydrological conditions. The analysis revealed insights into (1) the hydrogeological characteristics of the flow system, (2) the recharge processes, and (3) provided quantitative results about spring source vulnerability:

(1a) The coherence of the Jericho springs Sultan and Duyuk (air line distance of $3500 \mathrm{~m}$ ) to a common conduit system could be established by its similarity in hydrochemical time series, the transport signal at Sultan spring lagging the signal of the upgradient Duyuk spring by about 0.7 days, corresponding to a mean flow velocity of $220 \mathrm{~m} \mathrm{~h}^{-1}$.

(1b) The three large springs Auja, Duyuk and Sultan, located in the Jordan Valley or its escarpment are characterised by conduit restricted flow (Rosenthal and Kronfeld, 1982; Schmidt et al., 2014), hence a relatively steady discharge or a plateau in discharge is observed. In contrast, the comparatively small Samia spring, located about $400 \mathrm{~m}$ higher in the slopes towards the valley, exhibits typical karst spring discharge behaviour, i.e. pronounced discharge peaks following large precipitation events.

(2) Focussing of flow in the epikarst with subsequent rapid percolation towards the phreatic zone is expected to constitute important processes of groundwater recharge in the study area. Hydraulic response time for all monitored springs was less than one day after the onset of intensive precipitation events in the recharge area. This focussing is not restricted to areas of internal drainage, as these only occupy a small fraction of the study area. The infiltration of ephemeral wadi runoff into small ponors or ponor zones ("thalweg ponors") may provide recharge to the aquifers but likely do not constitute the bulk amount. However, the relative fraction of diffuse recharge through the fractured rock matrix still needs to be determined. 
(3) The volumes of the sections of the conduit systems participating in rapid transport were estimated at $6000 \mathrm{~m}^{3}$ for the Samia system, $140000 \mathrm{~m}^{3}$ for the Auja system, and approximately $180000 \mathrm{~m}^{3}$ for the Sultan/Duyuk system, respectively. Also, the mean lag time until event water arrival increases from about 1 day (Samia spring) to about 6 days (Sultan spring). With increasing lag time and conduit volume, the dispersion of the fast flow component increases. Hence, compared to very short-term breakthroughs which were assessed for the Samia spring (mean residence time fast flow component: 1-2 d), the width of event breakthroughs is about 10-40 days at the Sultan and Duyuk springs with mean residence times of the fast flow component of $\geq 10$ days. The results of this study enable operative measures to be undertaken (e.g. a contaminant load-optimised chlorination) until proper groundwater resource protection is applied.

The results enable the planning of subsequent tracer experiments (calculation of input mass and optimisation of sampling at the different springs, compare Worthington and Smart, 2013), which is mandatory for spring catchment delineation. In this karst environment, electrical conductivity is a suitable and easy to monitor proxy for the environmental tracer chloride. The unambiguous determination of the freshly recharged wastewater quantity to spring discharge requires the measurement of additional wastewater indicators (e.g. trace organics like caffeine, e.g. Hillebrand et al., 2012) that can be incorporated in a mixing model. Further high-resolution monitoring of additional parameters will improve the flow system interpretation. Turbidity, stable water isotopes, temperature, nitrate, bacteria (e.g. coliforms) and total organic carbon (e.g. Pronk et al., 2006) are expected to be useful for this purpose.

We feel that the application of high-resolution monitoring in semi-arid environments is lagging behind technical possibilities. However, high-resolution monitoring is not free of trouble either (e.g. sensor breakdowns, required data processing etc.). Especially in order to gauge discharge accurately, larger civil engineering works and frequent maintenance may be required. Nevertheless, the system insight gained from the high-resolution data likely justifies the investments.

\section{Acknowledgements}

This study was conducted within the framework of the multi-lateral research project "SMART Sustainable Management of Available Water Resources with Innovative Technologies" funded by BMBF (German Federal Ministry of Education and Research), references Nos. 02WM0802 and 02WM1081. Special thanks go to: Mohammed Najmi, Basir Hanna, and Ata Ishtewe for excellent precipitation and spring sampling; Ghazi Al-Naji, Jalal Bsharrat, Mohammed Khalaf, Bassam Sawalhi, and Subhi Samhan for their helpful support for spring site installations and discussions; Abu Ashraf, Steffen Fischer, Klaus Haaken, Mathias Toll, and many more persons for help during fieldwork; Anke von Gaza, Mechthild Rittmeier, and Tobias Licha for chemical analyses; Joe Nadolski for proofreading the manuscript. 


\section{References}

Amiel, R.B., Grodek, T., Frumkin, A., 2010. Characterization of the hydrogeology of the sacred Gihon Spring, Jerusalem: a deteriorating urban karst spring. Hydrogeology Journal 18, 1465-1479.

Amraoui, F., Razack, M., Bouchaou, L., 2003. Turbidity dynamics in karstic systems. Example of Ribaa and Bittit springs in the Middle Atlas (Morocco). Hydrological Sciences Journal 48, 971-984.

ANTEA, 1998. Well development study of the Eastern Aquifer Basin, northern districts of Palestine, Volume 1: Interim report, conceptual model. Unpublished ANTEA report No. A11903.

Arbel, Y., Greenbaum, N., Lange, J., Inbar, M., 2010. Infiltration processes and flow rates in developed karst vadose zone using tracers in cave drips. Earth Surface Processes and Landforms 35, 1682-1693.

Ashton, K., 1966. The analysis of flow data from karst drainage systems. Transactions of the Cave Research Group of Great Britain 7, 161-203.

Begin, Z.B., 1975. The geology of the Jericho sheet. Geological Survey of Israel, Bulletin 67, Jerusalem.

Birk, S., Liedl, R., Sauter, M., 2006. Karst spring responses examined by process-based modeling. Ground Water $44,832-836$.

Brouyère, S., 2004. A quantitative point of view of the concept of vulnerability. In: Zwahlen, F. (Ed.), Vulnerability and risk mapping for the protection of carbonate (karst) aquifers-Final report COST action 620. European Commission, Directorate-General for Research, Brussels, pp. 10-15.

Butscher, C., Huggenberger, P., 2008. Intrinsic vulnerability assessment in karst areas: a numerical modeling approach. Water Resources Research 44, W03408, doi:10.1029/2007WR006277.

Daly, D., Dassargues, A., Drew, D., Dunne, S., Goldscheider, N., Neale, S., Popescu, I.C., Zwahlen, F., 2002. Main concepts of the "European Approach" for karst-groundwater-vulnerability assessment and mapping. Hydrogeology Journal 10, 340-345.

Department of Land Settlement and Water Commissioner, 1947. Water measurements prior to October 1944. British Government of Palestine, Government Printer, Jerusalem.

Doummar, J., 2012. Identification of indicator parameters for the quantitative assessment of vulnerability in karst aquifers. PhD thesis, University of Göttingen, Göttingen. <http://hdl.handle.net/11858/00-1735-0000000D-F07C-8>.

Dreiss, S.J., 1989. Regional scale transport in a karst aquifer: 1. Component separation of spring flow hydrographs. Water Resources Research 25, 117-125.

Ford, D., Williams, P., 2007. Karst hydrogeology and geomorphology. Wiley, Chichester.

Foster, S., Hirata, R., Andreo, B., 2013. The aquifer pollution vulnerability concept: aid or impediment in promoting groundwater protection?. Hydrogeology Journal 21, 1389-1392.

Frind, E.O., Molson, J.W., Rudolph, D.L., 2006. Well vulnerability: A quantitative approach for source water protection. Ground Water 44, 732-742.

Frumkin, A., 1992. Karst origin of the upper erosion surface in the northern Judaean Mountains, Israel. Israel Journal of Earth Sciences 41, 169-176.

Frumkin, A., Fischhendler, I., 2005. Morphometry and distribution of isolated caves as a guide for phreatic and confined paleohydrological conditions. Geomorphology 67, 457-471. 


\section{Evaluation of rapid recharge processes and spring source vulnerability}

Galleani, L., Vigna, B., Banzato, C., Lo Russo, S., 2011. Validation of a Vulnerability Estimator for Spring Protection Areas: The VESPA index. Journal of Hydrology 396, 233-245.

George, A.I., 1989. Caves and drainage north of the Green River. In: White, W.B., White, E.L. (Eds.), Karst Hydrology-Concepts from the Mammoth Cave area. Van Nostrand Reinhold, New York, pp. 189-221.

Geyer, T., 2008. Process-based characterisation of flow and transport in karst aquifers at catchment scale. PhD thesis, University of Göttingen, Göttingen. <http://hdl.handle.net/11858/00-1735-0000-0006-B276-E>.

Goldreich, Y., 1994. The spatial distribution of annual rainfall in Israel-a review. Theoretical and Applied Climatology 50, 45-59.

Goldscheider, N., 2002. Hydrogeology and vulnerability of karst systems: Examples from the Northern Alps and the Swabian Alb. PhD thesis, University of Karlsruhe, Karlsruhe. <http://digbib.ubka.unikarlsruhe.de/volltexte/1812002>.

Goldscheider, N., 2010. Delineation of spring protection zones. In: Kresic, N., Stevanovic, Z. (Eds.), Groundwater hydrology of springs-Engineering, theory, management, and sustainability. Butterworth-Heinemann, Burlington, pp. 305-338.

Göppert, N., Goldscheider, N., 2008. Solute and colloid transport in karst conduits under low- and high-flow conditions. Ground Water 46, 61-68.

Gunn, J., 1983. Point-recharge of limestone aquifers-A model from New Zealand karst. Journal of Hydrology 61, 19-29.

Hillebrand, O., Nödler, K., Licha, T., Sauter, M., Geyer, T., 2012. Caffeine as an indicator for the quantification of untreated wastewater in karst systems. Water Research 46, 395-402.

Hötzl, H., 1996. Grundwasserschutz in Karstgebieten. Grundwasser 1, 5-11.

Jakucs, L. 1959. Neue Methoden der Höhlenforschung in Ungarn und ihre Ergebnisse. Die Höhle 10(4), 88-98.

Klein Tank, A.M.G., Wijngarrd, J.B., Konnen, G.P., Bohm, R., Demaree, A., Gocheve, M., Mileta, S., Pashiardis, L., Hejkrlik, C., Kern-Hansen, R., Heino, P., Bessemoulin, G., Muller-Westermeier, G., Tzanakou, M., Szalai, S., Palsdottir, D., Fitzgerald, D., Rubin, S., Capaldo, M., Maugeri, M., Leitass, A., Bukantis, A., Aberfeld, R., van Engelen, A.F.V., Forland, E., Mietus, M., Coelho, F., Mares, C., Razuvaev, V., Nieplova, E., Cegnar, T., López, J.A., Dahlstrom, B., Moberg, A., Kirchhofer, W., Ceylan, A., Pachaliuk, O., Alexander, L.V., Petrovic, P., 2002. Daily dataset of 20th-century surface air temperature and precipitation series for the European Climate Assessment. International Journal of Climatology 22, 1441-1453.

Krawczyk, W.E., Ford, D.C., 2006. Correlating specific conductivity with total hardness in limestone and dolomite karst waters. Earth Surface Processes and Landforms 31, 221-234.

Lange, J., Arbel, Y., Grodek, T., Greenbaum, N., 2010. Water percolation process studies in a Mediterranean karst area. Hydrological Processes 24, 1866-1879.

Lenz, R., 1969. Eine Strukturkarte von Westjordanien im Maßstab 1 : 250 000. Beihefte zum Geologischen Jahrbuch 81, 93-112.

Liñán Baena, C.L., Andreo, B., Mudry, J., Carrasco Cantos, F., 2009. Groundwater temperature and electrical conductivity as tools to characterize flow patterns in carbonate aquifers: The Sierra de las Nieves karst aquifer, southern Spain. Hydrogeology Journal 17, 843-853.

Magal, E., Arbel, Y., Caspi, S., Glazman, H., Greenbaum, N., Yechieli, Y., 2013. Determination of pollution and recovery time of karst springs, an example from a carbonate aquifer in Israel. Journal of Contaminant Hydrology 145, 26-36. 
Massei, N., Wang, H.Q., Dupont, J.P., Rodet, J., Laignel, B., 2003. Assessment of direct transfer and resuspension of particles during turbid floods at a karstic spring. Journal of Hydrology 275, 109-121.

Mimi, Z.A., Assi, A., 2009. Intrinsic vulnerability, hazard and risk mapping for karst aquifers: A case study. Journal of Hydrology 364, 298-310.

Palestinian Water Authority, 2000. Summary of Palestinian hydrologic data, Volume 1: West Bank. Palestinian Water Authority report, Ramallah.

Pinder, G.F., Jones, J.F., 1969. Determination of the ground-water component of peak discharge from the chemistry of total runoff. Water Resources Research 5, 438-445.

Pochon, A., Tripet, J., Kozel, R., Meylan, B., Sinreich, M., Zwahlen, F., 2008. Groundwater protection in fractured media: a vulnerability-based approach for delineating protection zones in Switzerland. Hydrogeology Journal 16, 1267-1281.

Pronk, M., Goldscheider, N., Zopfi, J., 2006. Dynamics and interaction of organic carbon, turbidity and bacteria in a karst aquifer system. Hydrogeology Journal 14, 473-484.

Quinlan, J.F., Smart, P.L., Schindel, G.M., Alexander Jr., E.C., Edwards, A.J., Smith, A.R., 1991. Recommended administrative/regulatory definition of karst aquifer, principles of classification of carbonate aquifers, practical evaluation of vulnerability of karst aquifers, and determination of optimum sampling frequency at springs. In: Proceedings of the third conference on hydrogeology, ecology, monitoring, and management of ground water in karst terranes, Nashville, pp. 573-635.

Ries, F., 2013. Local hydrological models and quantification of runoff for sub-basin Auja, in: Rahman, M.A. (Ed.), Deliverable 405-Local hydrological models and quantification of runoff. Unpublished report, BMBF IWRM R\&D Programme SMART, Göttingen, pp. 2-17.

Rofe \& Raffety Consulting Engineers, 1963. Jerusalem and district water supply: geological and hydrological report. Report to the Central Water Authority of the Hashemite Kingdom of Jordan, London.

Rosenthal, A., Kronfeld, J., 1982. ${ }^{234} \mathrm{U}-238 \mathrm{U}$ disequilibria as an aid to the hydrological study of the Judea Group aquifer in eastern Judea and Samaria, Israel. Journal of Hydrology 58, 149-158.

Ryan, M., Meiman, J., 1996. An examination of short-term variations in water quality at a karst spring in Kentucky. Ground Water 34, 23-30.

Schmidt, S., Fischer, S., Toll, M., Ries, F., Zayed, O., Guttman, J., Marei, A., Weiss, M., Geyer, T., Sauter, M., 2012. Design and setup of a high resolution hydrometric monitoring network in a semi-arid karst environment - West Bank. In: Rausch, R., Schüth, C., Himmelsbach, T. (Eds.), Hydrogeology of arid environments. Borntraeger, Stuttgart, pp. 147-150.

Schmidt, S., Geyer, T., Guttman, J., Marei, A., Ries, F., Sauter, M., 2014. Characterisation and modelling of conduit restricted karst aquifers - Example of the Auja spring, Jordan Valley. Journal of Hydrology 511, 750-763.

Schmidt, S., Geyer, T., Marei, A., Guttman, J., Sauter, M., 2013. Quantification of long-term wastewater impacts on karst groundwater resources in a semi-arid environment by chloride mass balance methods. Journal of Hydrology 502, 177-190.

Shanafield, M., Cook, P.G., 2014. Transmission losses, infiltration and groundwater recharge through ephemeral and intermittent streambeds: A review of applied methods. Journal of Hydrology 511, 518-529.

Sweeting, M.M., 1972. Karst landforms. Macmillan, London.

Vías, J., Andreo, B., Ravbar, N., Hötzl, H., 2010. Mapping the vulnerability of groundwater to the contamination of four carbonate aquifers in Europe. Journal of Environmental Management 91, 1500-1510. 
Evaluation of rapid recharge processes and spring source vulnerability

White, W.B., 2002. Karst hydrology: recent developments and open questions. Engineering Geology 65, 85-105.

Williams, P.W., 1983. The role of the subcutaneous zone in karst hydrology. Journal of Hydrology 61, 45-67.

Wolfer, J., 1998. Hydrogeological investigation along the Jerusalem - Jericho transect (Wadi el Qilt), Israel/West Bank. Diploma thesis, University of Karlsruhe, Karlsruhe.

Worthington, S.R., Smart, C.C., 2013. Determination of tracer mass for effective groundwater tracer tests. Carbonates and Evaporites, 1-8, doi: 10.1007/s13146-013-0171-4. 


\section{Chapter 6}

\section{Conclusions}

\section{I Integration and evaluation of characterisation methods and results}

In order to assess the system factors stated in chapter 1 on a catchment scale, different methods were applied to the study area. The main factors are subsequently discussed.

(1) The assessment of groundwater recharge as the most relevant water budget component and driver of flow-, transport-, and vulnerability dynamics is covered in all three main chapters (3-5): In chapter 3 the mean long-term recharge fraction from precipitation for 33 spring catchments in the study area was estimated by a chloride mass balance approach, based on the natural chloride background concentration in spring water. In chapter 4 a high-resolution time series of recharge (daily values of deep percolation) was calculated by a combined lumped soil water balance and reservoir model approach. As catchment areas are not delineated, a mandatory input for this approach is the mean long-term recharge fraction calculated in chapter 3. In chapter 5 the rapid recharge processes and the fast flow component, which are critical in terms of rapid spring contamination, were evaluated based on a spring event analysis. The results of chapters 4 and 5 both indicate a focussing mechanism in the epikarst and preferential flow in the vadose zone.

From the model results (chapter 4) an empirical relationship of recharge as a function of annual precipitation was derived (Fig. 6.1). Compared to empirical equations derived from transient groundwater flow modelling of the regional carbonate aquifer (Guttman and Zuckermann, 1995; chapter 3) and of small spring catchments (Weiss and Gvirtzmann, 2007), a slightly steeper relation between precipitation and recharge was found. The equations for the larger balance areas level out the small scale differences encountered for the spring catchments. The equation derived from the modelling results for Auja spring is remarkably similar to the simple empirical equation of Goldschmidt (1959) derived from water budget calculations: recharge $R=0.86$ * (annual precipitation $P-360 \mathrm{~mm}$ ). The main difference is that the model derived polynomial equation, considering an event based analysis (e.g. input data with a daily frequency), calculates more recharge for rather dry years $(P<450 \mathrm{~mm})$ and very wet years $(P \geq 800 \mathrm{~mm})$. A main issue that restricts the use of empirical equations is that they do not take differences in actual evapotranspiration into account. For years with equal precipitation, actual evapotranspiration and recharge can vary by more than $100 \mathrm{~mm}$ (chapter 4; Fig. 6.1). 


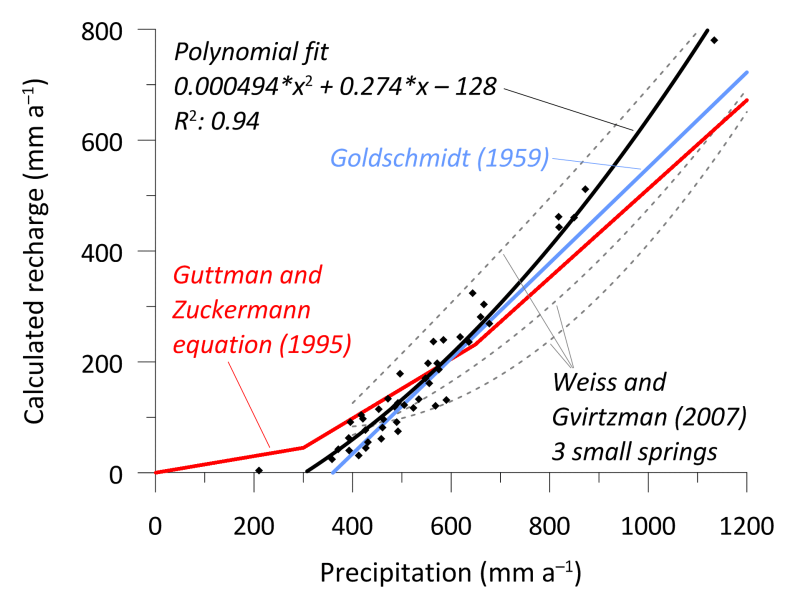

Fig. 6.1: Empirical polynomial equation for groundwater recharge estimation from annual precipitation derived from the 45-year model results for the Auja spring catchment. A comparison to the equations of Goldschmidt (1959), Guttman and Zuckermann (1995), and Weiss and Gvirtzman (2007) is provided.

(2) Aquifer parameters, predominantly porosity, were estimated in chapters 4 and 5: The mean porosity of the fractured rock matrix was estimated via model calibration to about $2 \%$ for the aquifer system of Auja spring. The mean effective porosity value for the highly permeable system was estimated at ca. $0.4 \%$. This value is believed to include next to the conduit system also other more permeable compartments of the aquifer porosity such as large fractures and karst voids (chapter 4). The conduit system volume estimated by the lag time method for the Auja system is about $140,000 \mathrm{~m}^{3}$ (chapter 5). If we consider-although this is a very uncertain estimation-the modelled mean storage in the highly permeable system of ca. 1,400,000 $\mathrm{m}^{3}$ to constitute an estimate of the highly permeable system porosity, the conduit system is about $10 \%$ of this volume. Based on this ratio, the volume of the conduit system constitutes $0.04 \%$ of the mean aquifer volume. This value compares well to the fraction of $0.03 \%$ derived by Atkinson (1977) and Sauter (1992) for conduit systems of mature karst aquifers in Great Britain and Germany. The results suggest that the rapidly drainable storage connected to the main karst conduit system is considerably larger than the conduit system itself (see Section 4.5.2 and Reimann et al., 2014).

(3) The quantitative flow dynamics were assessed in chapters 4 and 5. In chapter 4 the dynamics of the Auja spring flow system were assessed by a spring event and recession analysis as well as a mathematical reservoir model approach. The hydrogeological and modelling methods results indicate an important conduit-matrix exchange in this conduit-restricted aquifer. This may be the result of a build-up of groundwater head once the outflow threshold is reached. In chapter 5 the dynamics of the Samia spring flow system was assessed. This spring displayed a maximum discharge of ca. $0.45 \mathrm{~m}^{3} \mathrm{~s}^{-1}$ for the two largest monitored recharge events. Those maximum discharge periods also displayed the form of a plateau, nevertheless of much shorter duration (ca. 1-2 days) compared to the extended plateaus of the large springs in the Jordan Valley, like e.g. Auja (Fig. 5.4). This mild conduit restriction in comparison to the large Jordan Valley springs (Table 6.1) indicates a higher degree of karstification for the Samia spring system. This is possibly related to its perched nature (compare the much higher elevation, Table 6.1), i.e. that it was not influenced by the Jordan Valley base level changes (Section 4.2.3).

(4) Anthropogenic and potential geogenic impacts on groundwater were assessed in chapter 3. Wastewater infiltration (which can be regarded as artificial recharge) was quantified by a chloride 
end-member mixing model via determination of the natural background concentration of chloride in groundwater. A possible geogenic impact of basin brines on the spring aquifer system could be excluded by an analysis of the chloride/bromide ratio in spring water. To the best of my knowledge, chapter 3 is hitherto the only study concerned with the evaluation of long-term water quality data and the determination of natural background concentrations conducted for karst aquifers in (semi-)arid environments. I fully agree with Edmunds and Shand (2008), who state that (p. 454): "It is instructive that only few records with quality trends up to or in excess of 70 years are available, and in several countries it has proved difficult to find any long-term records." They conclude that "More archive data need to be assembled to demonstrate long-term trends and more effort is needed to conserve and interpret suitable archive data."

Table 6.1: Ratio of maximum observed to mean spring discharge for the monitored springs. The discharge data (courtesy of the Palestinian Water Authority) refer to the hydrological years 1968-2000 unless otherwise stated.

\begin{tabular}{lcccc}
\hline Spring & Elevation $(\mathrm{m}$ asl $)$ & $\mathrm{Q}_{\operatorname{mean}}\left(\mathrm{m}^{3} \mathrm{~s}^{-1}\right)$ & $\mathrm{Q}_{\max }\left(\mathrm{m}^{3} \mathrm{~s}^{-1}\right)$ & $\mathrm{Q}_{\max } / \mathrm{Q}_{\operatorname{mean}}$ \\
\hline Sultan (Elisha) & -215 & 0.18 & 0.20 & 1.1 \\
Duyuk & -110 & 0.26 & 0.34 & 1.3 \\
Auja & 20 & 0.29 & 0.71 & 2.4 \\
Samia & 435 & $0.021^{\mathrm{a}}$ & $0.45^{\mathrm{b}}$ & $\sim 20$ \\
\hline
\end{tabular}

a Mean pumping abstraction of the well tapping the spring aquifer. According to the considerations of Section

5.4.1, the mean natural spring discharge is expected to be higher than the abstracted value.

b Maximum discharge measured during the hydrological years of 2012 and 2013.

(5) Transport dynamics and spring source vulnerability were mainly dealt with in chapter 5 through a combined analysis of spring events and environmental tracer monitoring in precipitation and in spring water. The results confirmed the expected high flow and transport dynamics. The low discharge dynamics observed for the springs Sultan and Duyuk-due to the conduit restricted flow mechanism - is not a reliable indicator for low transport dynamics and hence low spring source vulnerability. Therefore, high-frequency water quality and physicochemical parameter monitoring is mandatory for spring source vulnerability evaluation.

It was demonstrated that even with fundamental characteristics (e.g. catchment boundaries and flow-systems) being largely unknown, karst aquifers in semi-arid environments can be conveniently characterised. This study highly benefited from long-term monitoring data. Therefore, the continuation and initiation of long-term monitoring schemes is highly encouraged, especially for semi-arid regions.

\subsection{Monitoring and characterisation strategy for karst aquifers in semi-arid environments}

In the strategy suggested below I try to give some general suggestions for the monitoring and characterisation of semi-arid karst aquifers discharged by springs. Recommendations like the following are unquestionable biased by the experience of the investigator and the characteristics 


\section{Conclusions}

of the study area. Nevertheless, I would like to emphasise some specific points with focus on the practical monitoring aspects and futhermore to suggest methods with an expected good ratio of benefit for cost. As stated by Van Lanen (1998): "Monitoring is a dynamic process; we never get it right at the beginning". This is certainly true and I hope the following suggestions to be beneficial for hydrogeologists concerned with the characterisation of karst aquifers in (semi-)arid climates:

(1) Collect and evaluate all available hydrological information. Priority is on long-term precipitation and spring discharge data in order to determine the long-term water balance and the flow system dynamics due to variable climate conditions (compare chapters 3, 4, and Healy, 2010).

(2) Monitoring of the springs is mandatory since they usually provide integral information of the whole ground water catchment (e.g. Quinlan et al., 1991).

(2a) even basic water quality and physicochemical parameter monitoring should already be conducted by automatic continuous logging equipment, constrained to the parameters electrical conductivity, temperature, and water level, often combined in one commercially available probe with low power consumption. Those parameters usually do not display a large sensor drift. This way extensive effort for calibration and raw data manipulations can be avoided.

(2b) next important are the assessment of the output quantities and discharge behaviour of the system. A basic assessment may constitute of periodically discharge measurements (e.g. at a monthly frequency). High-frequency measurements will usually be conducted at a weir, flume or stream gauge. This often requires major civil engineering constructions and nevertheless frequent fieldwork (e.g. maintenance) and office work (e.g. data manipulations) (chapters 2, 4, and 5).

(3) Spring monitoring should be done in combination with a high-resolution measurement of precipitation in the recharge area (temporal and spatial), preferably with automatic instruments of tipping-bucket type. A very interesting and relatively easy to monitor environmental tracer is chloride. In accordance with Scanlon et al. (2006), I would like to emphasise on expanding the monitoring efforts for a continuous assessment of wet and dry chloride deposition in (semi-)arid regions. Furthermore, automatic monitoring stations for air temperature should be implemented for the assessment of potential evapotranspiration (chapter 4). Despite widely employed (and also installed during this study), "full" meteorological stations may be largely unnecessary for basic potential evapotranspiration calculation. For example, those stations require permanent maintenance, e.g. a daily cleaning of the global radiation sensor, which is heavily influenced by dust deposition in dry environments (e.g. Stanhill, 2002). This rather subjective opinion is backed up by studies such as Oudin et al. (2005), where simple temperature and radiation based empirical equations for the calculation of potential evapotranspiration performed equal or even superior to popular physically based equations featuring a high data demand.

(4) Refinement of the monitoring is nearly unlimited but should always serve a specific purpose. "High-end" monitoring may include further continuous spring measurements, e.g. regarding turbidity, ions, isotopes etc. or a comprehensive measurement of actual evapotranspiration in the recharge area by eddy covariance methods. However, automatic hydrometric monitoring is still not the "fire-and-forget" approach one might expect. The current study employed about 20 different types (or a combination) of sensors, probes, and data loggers from various manufacturers over several years. While some performed exceedingly well, about three quarter of 
the employed instrument types experienced more or less severe breakdowns. Some were really trouble-ridden. This often concerns only specific instruments from manufacturers (independent of the manufacturing company size), while others perform well. Suggestions: (a) keep need for mains current as low as possible and (b) two redundant probes/sensors at the same (important) monitoring location might prevent a lot of data gaps and will provide a very valuable cross-check in case of dubious readings.

(5) The analysis of the monitoring data can be conducted employing the methods suggested in chapters 3-5 and summarised in the previous section.

(6) A method providing valuable results in almost all karst environments are artificial tracer tests. The hydrogeological characterisation of the catchment via spring monitoring should be started beforehand, in order to avoid less-than-ideal conducted tracer tests as far as possible.

(7) Process based modelling provides further quantitative insight into the system and also enables predictive capabilities. For mediocre investigated "real-life" karst aquifers, lumped parameter reservoir models probably constitute the best compromise between the necessary simplification of the system and the ability to conceptually include process-based system characteristics into the model.

\subsection{Perspectives}

(1) For the study area, the delineation of the groundwater catchments is one next large step for further characterisation. It requires the conduction of a large-scale tracer test program. Because of the paucity of suitable input locations this is a difficult task. During this study, only one thalweg ponor with a capacity of at least $0.015 \mathrm{~m}^{3} \mathrm{~s}^{-1}$ about $500 \mathrm{~m}$ downstream of Auja spring could be identified. Field surveys shortly after major precipitation events in the recession phase of surface runoff are suggested for this task. From the results of this study, important prerequisites for the planning and execution of a tracer test program could be gained. For example the detection of the coherence of the two large Jericho springs to a common flow system and the mean residence time of the fast flow fraction provides information for the calculation of the appropriate tracer input mass and the expected time till tracer breakthrough in order to optimise sampling (e.g. Worthington and Smart, 2013).

(2) This study focussed on the key monitoring parameters of karst systems (Fig. 1.3), for example at karst springs, where the integral catchment response can be assessed. In favourable conditions in this or other semi-arid settings, also the intermediate parts of the flow system should be investigated such as the epikarst and the vadose zone. Such studies (e.g. Lange et al., 2010) enable the evaluation of the relative significance of the different recharge processes especially focussing mechanisms in the near-surface zone and transfer mechanisms through the vadose zone. To further integrate and analyse flow and transport processes in semi-arid karst systems, a reservoir model coupling flow and transport needs to be developed. 


\section{References}

Atkinson, T.C., 1977. Diffuse flow and conduit flow in limestone terrain in the Mendip Hills, Somerset (Great Britain). Journal of Hydrology 35, 93-110.

Edmunds, W.M., Shand, P., 2008. Natural groundwater quality - Summary and significance for water resources management. In: Edmunds, W.M., Shand, P. (Eds.), Natural groundwater quality. Blackwell Publishing, Malden, pp. 441-462.

Goldschmidt, M.J., 1959. On the water balances of several mountain underground water catchments in Israel and their flow patterns. Hydrological Service, Hydrological Paper No. 4, Jerusalem.

Guttman, J., Zuckerman, H., 1995. Flow model in the eastern basin of the Judea and Samaria hills. Tahal Consulting Engineers Ltd., Report No. 01/95/66, Tel Aviv. (in Hebrew).

Healy, R.W., 2010. Estimating groundwater recharge. Cambridge University Press, Cambridge.

Lange, J., Arbel, Y., Grodek, T., Greenbaum, N., 2010. Water percolation process studies in a Mediterranean karst area. Hydrological Processes 24, 1866-1879.

Oudin, L., Hervieu, F., Michel, C., Perrin, C., Andréassian, V., Anctil, F., Loumagne, C., 2005. Which potential evapotranspiration input for a lumped rainfall-runoff model? Part 2-Towards a simple and efficient potential evapotranspiration model for rainfall-runoff modelling. Journal of Hydrology 303, 290-306.

Quinlan, J.F., Smart, P.L., Schindel, G.M., Alexander Jr., E.C., Edwards, A.J., Smith, A.R., 1991. Recommended administrative/regulatory definition of karst aquifer, principles of classification of carbonate aquifers, practical evaluation of vulnerability of karst aquifers, and determination of optimum sampling frequency at springs. In: Proceedings of the third conference on hydrogeology, ecology, monitoring, and management of ground water in karst terranes, Nashville, pp. 573-635.

Reimann, T., Giese, M., Geyer, T., Liedl, R., Maréchal, J.C., Shoemaker, W.B., 2014. Representation of water abstraction from a karst conduit with numerical discrete-continuum models. Hydrology and Earth System Sciences 18, 227-241.

Sauter, M., 1992. Quantification and forecasting of regional groundwater flow and transport in a karst aquifer (Gallusquelle, Malm, SW. Germany). PhD thesis, Tübinger Geowissenschaftliche Arbeiten C13, Tübingen.

Scanlon, B.R., Keese, K.E., Flint, A.L., Flint, L.E., Gaye, C.B., Edmunds, W.M., Simmers, I., 2006. Global synthesis of groundwater recharge in semiarid and arid regions. Hydrological Processes 20, 3335-3370.

Stanhill, G., 1992. Accuracy of global radiation measurements at unattended, automatic weather stations. Agricultural and Forest Meteorology 61, 151-156.

Van Lanen, H.A.J., 1998. Monitoring for groundwater management in (semi-)arid regions. Studies and Reports in Hydrogeology 57, UNESCO Publishing, Paris.

Weiss, M., Gvirtzman, H., 2007. Estimating ground water recharge using flow models of perched karstic aquifers. Ground Water 45, 761-773.

Worthington, S.R., Smart, C.C., 2013. Determination of tracer mass for effective groundwater tracer tests. Carbonates and Evaporites, 1-8, doi: 10.1007/s13146-013-0171-4. 


\section{Sebastian Schmidt}

\section{Persönliche Daten}

$\begin{array}{ll}\text { geboren am } & \text { 6. Mai } 1978 \\ \text { in } & \text { Lichtenfels } \\ \text { Nationalität } & \text { deutsch } \\ \text { Familienstand } & \text { ledig }\end{array}$

\section{Hochschulausbildung}

$07 / 2007-05 / 2014$

\section{Georg-August-Universität Göttingen}

Promotionsstudium Geowissenschaften

Geowissenschaftliches Zentrum Göttingen

Abteilung Angewandte Geologie, Prof. Dr. Martin Sauter

II//998-0I/2005

\section{Universität Bayreuth \\ Diplom-Geoökologie}

Hauptfächer: Geologie, Hydrologie

Nebenfächer: Bodenkunde, Geomorphologie, Verfahrenstechnik

Diplomarbeit: Hydrogeologische Erkundung im Gebiet von

Almodóvar del Pinar (Provinz Cuenca, Spanien) mit geologischen, geophysikalischen und luftbildgeologischen Methoden

\section{Beruflicher Werdegang}

seit $07 / 2007$

\section{Georg-August-Universität Göttingen}

Wissenschaftlicher Mitarbeiter am Geowissenschaftlichen Zentrum, Abteilung Angewandte Geologie

v.a. Projektmanagement, Projektbearbeitung und Finanzverwaltung im Projekt „SMART - Sustainable Management of Available Water Resources with Innovative Technologies“, Phasen I \& II, gefördert durch das BMBF, Projektmanager seit Herbst 2009

$06 / 2005-06 / 2007$

\section{TÜV NORD SysTec GmbH \& Co. KG, Hamburg}

Projektingenieur Georadar, zerstörungsfreie Werkstoffprüfung

$11 / 1997-11 / / 998$

Frankenwaldklinik Kronach

Zivildienst als Pflegekraft im Bereich Innere Medizin 